\title{
The agency permanent establishment : de vaste vertegenwoordiger
}

Citation for published version (APA):

Pleijsier, A. (2000). The agency permanent establishment : de vaste vertegenwoordiger. [Doctoral Thesis, Maastricht University]. Datawyse / Universitaire Pers Maastricht. https://doi.org/10.26481/dis.20001103ap

Document status and date:

Published: 01/01/2000

DOI:

10.26481/dis.20001103ap

Document Version:

Publisher's PDF, also known as Version of record

\section{Please check the document version of this publication:}

- A submitted manuscript is the version of the article upon submission and before peer-review. There can be important differences between the submitted version and the official published version of record.

People interested in the research are advised to contact the author for the final version of the publication, or visit the DOI to the publisher's website.

- The final author version and the galley proof are versions of the publication after peer review.

- The final published version features the final layout of the paper including the volume, issue and page numbers.

Link to publication

\footnotetext{
General rights rights.

- You may freely distribute the URL identifying the publication in the public portal. please follow below link for the End User Agreement:

www.umlib.nl/taverne-license

Take down policy

If you believe that this document breaches copyright please contact us at:

repository@maastrichtuniversity.nl

providing details and we will investigate your claim.
}

Copyright and moral rights for the publications made accessible in the public portal are retained by the authors and/or other copyright owners and it is a condition of accessing publications that users recognise and abide by the legal requirements associated with these

- Users may download and print one copy of any publication from the public portal for the purpose of private study or research.

- You may not further distribute the material or use it for any profit-making activity or commercial gain

If the publication is distributed under the terms of Article $25 \mathrm{fa}$ of the Dutch Copyright Act, indicated by the "Taverne" license above, 


\section{The Agency Permanent Establishment}


Copyright (C) Arthur Pleijsier, Maastricht 2000 All rights reserved. No part of this publication may be reproduced, used or transmitted in whole or in part, in any form or by means - whether graphics, electronic or mechanical, including photocopying, recording, taping or information storage and retrieval systems without prior written permission from the publisher or the author, except for the inclusion of brief quotations in a review.

ISBN 9052782881

Datawyse | Universitaire Pers Maastricht 


\section{The Agency Permanent Establishment}

De vaste vertegenwoordiger

\section{Proefschrift}

ter verkrijging van de graad van doctor aan de Universiteit Maastricht, op gezag van de Rector Magnificus,

Prof.dr. A.C. Nieuwenhuijzen Kruseman, volgens het besluit van het College van Decanen, in het openbaar te verdedigen op vrijdag 3 november 2000 om 14.00 uur

door

\section{Arthur Pleijsier}

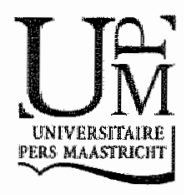




\section{Promotor:}

Prof.dr. A.H.M. Daniels

Beoordelingscommissie:

Prof.mr. H.J. de Kluiver (voorzitter)

Prof.dr. W.F.J. Buijink

Prof. L. Hinnekens (Universiteit van Antwerpen)

Prof.mr. C. van Raad (Universiteit Leiden) 


\section{Table of Contents}

\section{Introduction}

1.1 Structure and Methodology ..................................................................

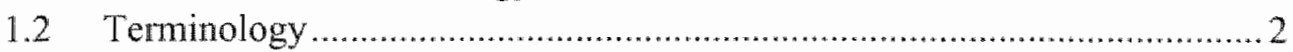

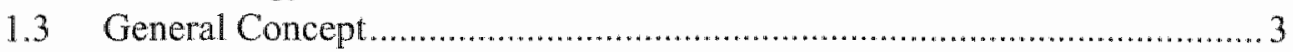

\section{Agents in Commercial Law}

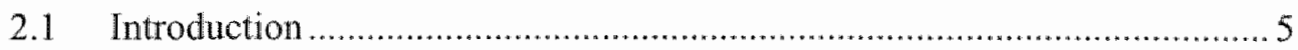

2.2 The Law of Agency in Common Law....................................................

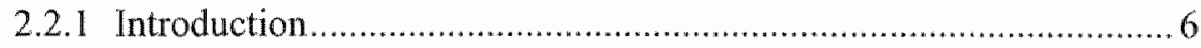

2.2.2 Explicit, Implied and Apparent Authority .......................................

2.2.3 The Concept of the Undisclosed Principal....................................... 8

2.2.4 The Unnamed Principal ............................................................ 12

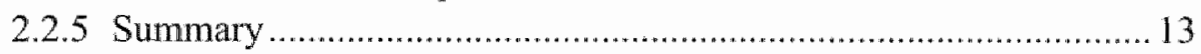

2.3 The Law of Agency According to Civil Law......................................... 13

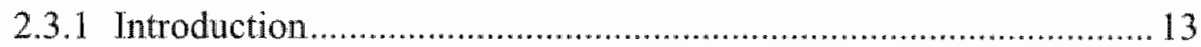

2.3.2 Direct Representation................................................................ 15

2.3.3 Indirect Representation ............................................................ 15

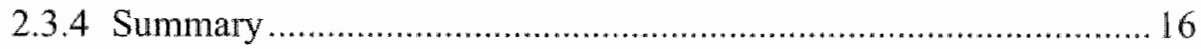

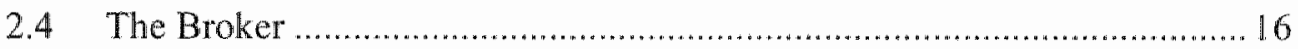

2.4.1 According to Common Law ........................................................ 16

2.4.2 According to Civil Law .......................................................... 17

2.5 The Commission Agent ................................................................... 18

2.5.1 According to Common Law...................................................... 18

2.5.2 According to Civil Law ............................................................. 19

2.6 Schedule of Commercial Agents and Other Representatives....................21

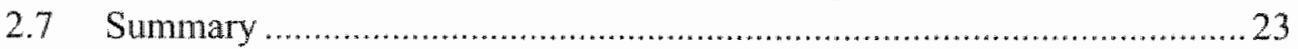




\section{The German Agency Permanent Establishment}

3.1 Introduction $\ldots$

3.2 The First Appearance of the Agency PE ............................................. 25

3.3 The Development of the Concept of the Permanent Agent ..................... 27

3.4 The Agency PE in Early German Legislation and Case Law ................... 29

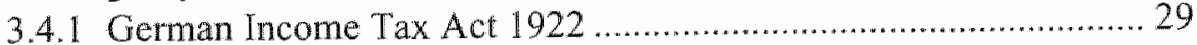

3.4.2 German case law................................................................. 30

3.5 The 1932 League of Nations German Report ...................................... 35

3.6 German Domestic Tax Law ................................................................ 37

3.7 The Agency PE in German Double Taxation Conventions ..................... 38

3.8 Article 16 Tax Revision Law............................................................ 40

3.9 Article 13 General Fiscal Law ...................................................... 41

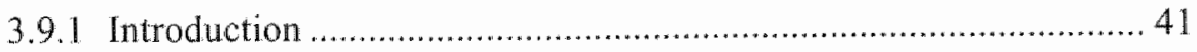

3.9.2 Conducting Business for an Enterprise .................................... 42

3.9.3 Acting Durably and Permanently ................................................. 43

3.9.4 Subjected to Business Instructions ............................................. 43

3.10 Section 222 Income Tax Act Guidelines ......................................... 46

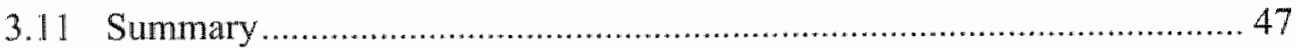

\section{The U.K. Agency PE Concept}

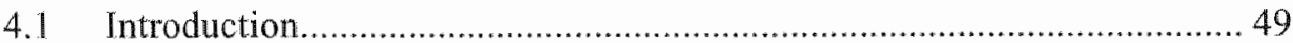

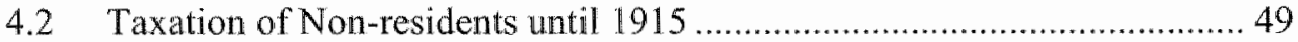

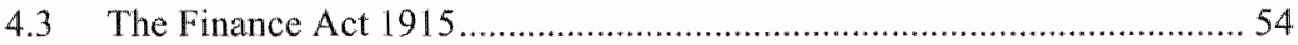

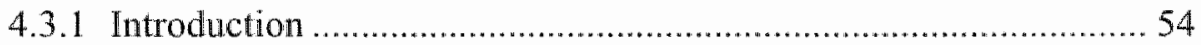

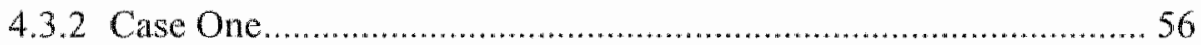

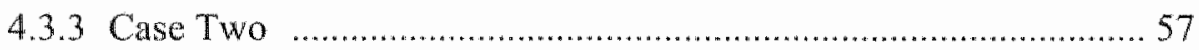

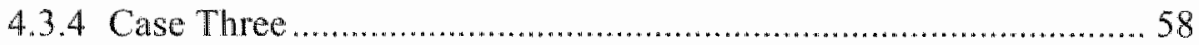

4.3.5 Extending the Taxable Base of Non-residents .............................. 58

4.3.5.1 Not Receiving Profits ................................................... 58

4.3.5.2 Branch or Manager ....................................................... 59

4.3.5.3 Anti-avoidance Legislation........................................... 59

4.3.6 Limiting the Taxable Base of Non-residents ................................ 6]

4.3.6.1 Exclusion of the Broker and General Commission Agent.. 61

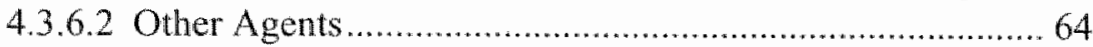

4.3.6.3 The Double Foreigner Exemption .................................... 65

4.4 The Finance Act 1925 ....................................................................6 66

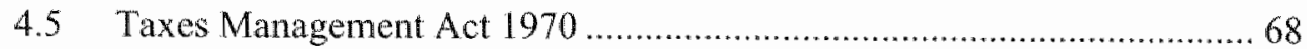

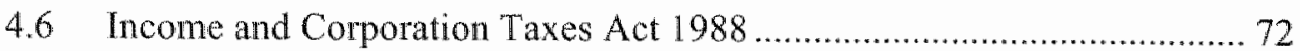

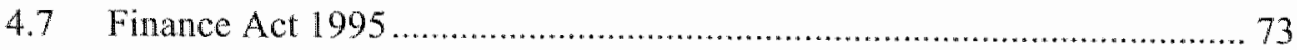


4.8 The UK Agency Concept in Double Taxation Conventions ..................... 73

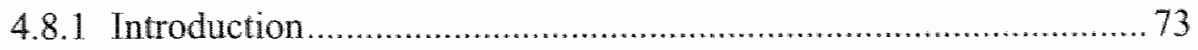

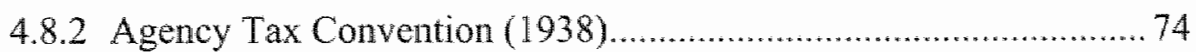

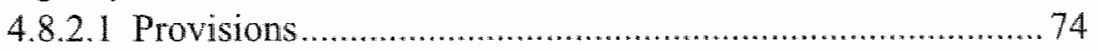

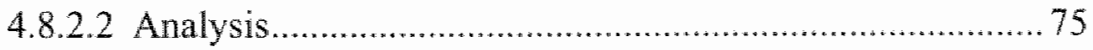

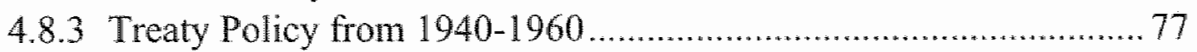

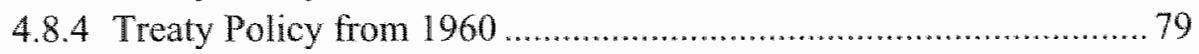

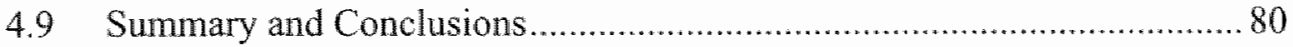

\section{The Agency PE according to United States Tax Law}

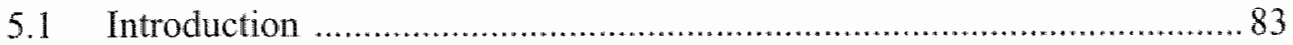

5.2 U.S. taxation of Foreign Individuals and Corporations........................... 84

5.3 U.S. Source Income or Foreign Source Income ........................................8 85

5.4 Foreign Source Income Eamed Through a U.S. Office ............................. 85

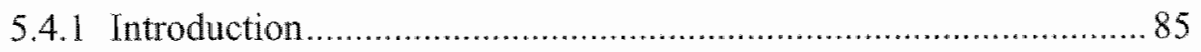

5.4.2 The U.S. Agent and Office Requirements ..................................86

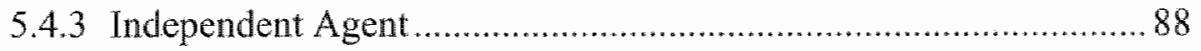

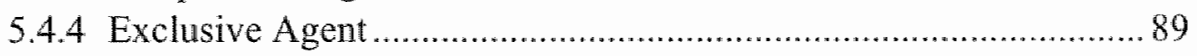

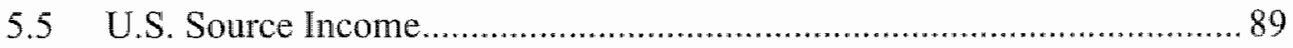

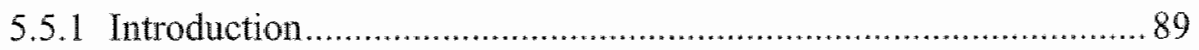

5.5.2 Non-Business U.S. Source Income ............................................ 90

5.5.3 U.S. Trade or Business Concept ....................................................90

5.5.4 Effectively Connected Income.................................................. 91

5.5.5 Foreign Corporation receiving U.S. Source Income through a U.S. Agent ............................................................. 93

5.5.6 IRC Exemption Provisions .........................................................96

5.5.7 Trading in Stocks, Securities or Commodities...............................97

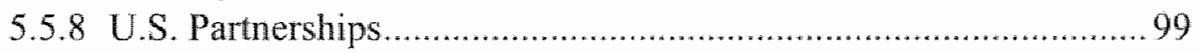

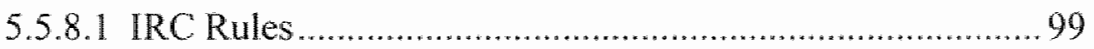

5.5.8.2 U.S. Case Law ........................................................... 100

5.6 Double Taxation Conventions.............................................................. 101

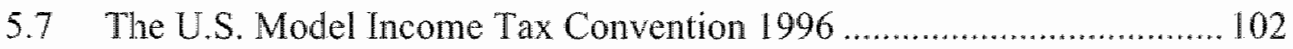

5.8 Differences Between U.S. Model 1996 and OECD Model..................... 104

5.9 Agency PE Provisions in U.S. Treaties ............................................. 104

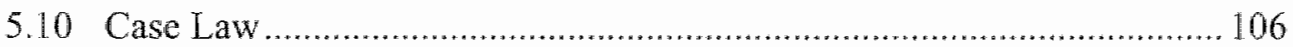

5.10.1 The Taise Case ........................................................................ 106

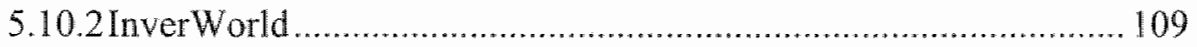

5.11 Summary and Conclusions............................................................. 111 


\section{The Dutch Agency PE Concept}

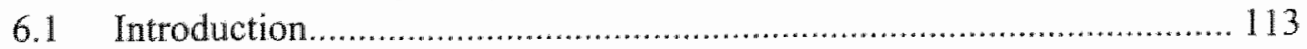

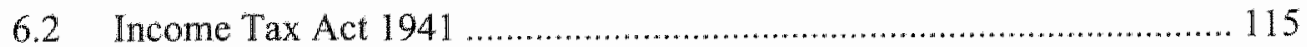

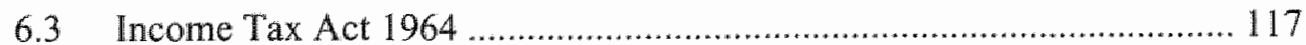

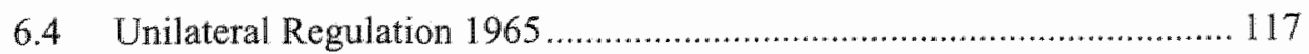

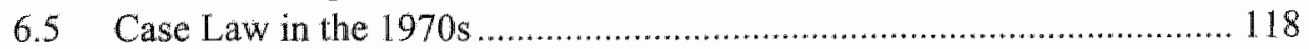

6.6 Kingdom Tax Regulation................................................................ 119

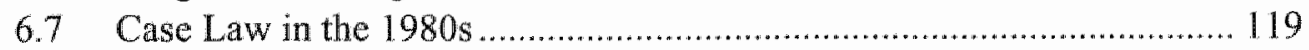

6.8 Double Taxation Conventions ........................................................ 120

6.9 Ship Broker Case .......................................................................... 122

6.10 The Dutch Insurance Agent Case ...................................................... 123

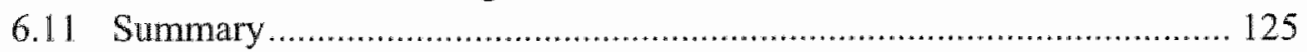

\section{The League of Nations \& $\mathrm{OECD}$}

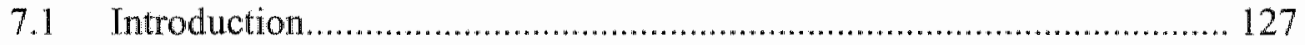

7.2 The Agency PE According to the League of Nations (1921-1929)........ 128

7.2. J The 1927 League of Nations Draft Convention .......................... 128

7.2.2 The Agency PE in Tax Treaties from 1921-1929 ....................... 130

7.2.3 Report of the Fiscal Committee (1929) .................................... 132

7.3 The Agency PE According to the League of Nations (1930-1947) ........ 138

7.4 The International Chamber of Commerce ........................................... 140

7.5 The Mexico/London Model Conventions.......................................... 141

7.5.1 Introduction ........................................................................... 141

7.5.2 The Agency PE According to the Mexico/London Conventions .. 141

7.5.3 The Independent Agent .......................................................... 144

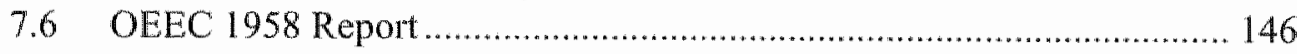

$7.7 \quad 1963$ OECD Model Treaty .............................................................. $\$ 49$

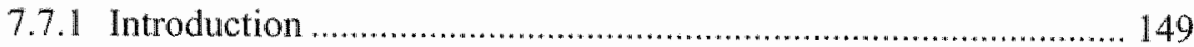

7.7.2 The Agency PE in the 1963 Model .......................................... 149

7.7.3 The Independent Agent ........................................................ 151

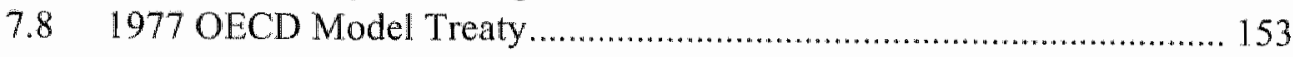

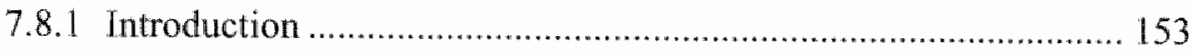

7.8.2 The Agency PE in the 1977 Model ......................................... 153

7.8.3 The Independent Agent .......................................................... 155

7.91980 UN Model Double Taxation Convention.................................... 156

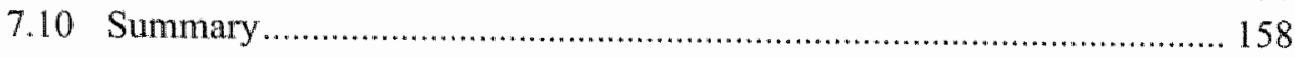




\section{Current Agency PE Definition}

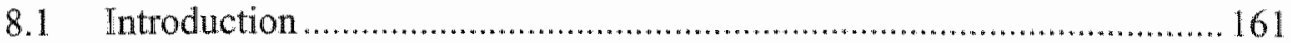

8.2 Article 5, paragraph 5, OECD Model ............................................. 161

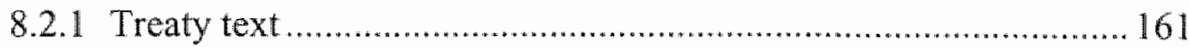

8.2.2 Paragraph 5 in Relation to Paragraphs 1 and 2 ........................ 161

8.2.3 A Person other than an Agent of an Independent Status.............. 163

8.2.4 Acting on Behalf of an Enterprise........................................... 164

8.2.4.1 General Observations ................................................ 164

8.2.4.2 The Entrepreneur is Both Principal and Agent ................. 164

8.2.4.3 Fixed Place of Business ............................................... 166

8.2.4.4 A General PE Combined with an Agency PE ................. 168

8.2.5 The Agent's Authority ............................................................ 168

8.2.6 The Scope of the Agent's Authority .......................................... 171

8.2.7 The Agent's Activities ......................................................... 172

8.2.7.1 Introduction .............................................................. 172

8.2.7.2 Advertising and Promotional Activities......................... 172

8.2.7.3 Mixed Activities......................................................... 173

8.2.7.4 A Principal with a PE and an Agency PE in the Same State.................................................................. 175

8.2.7.5 The Sub-Agent .......................................................... 176

8.2.7.6 Preparatory or Auxiliary Activities................................ 176

8.2.7.7 After-Sale Services .................................................. 177

8.2.7.8 Soliciting and Concluding Contracts ............................ 178

8.2.7.9 Marketing Agent ...................................................... 180

8.2.8 In the Name of .................................................................. 181

8.2.9 Habitually Exercising the Authority ....................................... 183

8.3 Article 5, Paragraph 6, OECD Model ............................................. 185

8.3.1 Treaty Text ....................................................................... 185

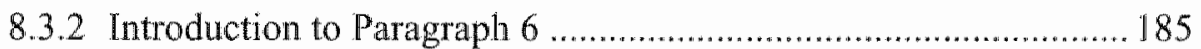

8.3.3 Broker ............................................................................ 186

8.3.4 General Commission Agent ................................................... 187

8.3.5 The Independent Agent............................................................. 188

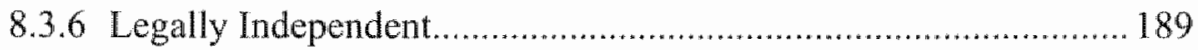

8.3.7 Economically Independent ................................................. 190

8.3.8 Ordinary Course of his Business ................................................. 191

8.3.9 Interpretation of the Agency PE .............................................. 193

8.3.9.1 Introduction............................................................... 193

8.3.9.2 Avery Jones and Ward on the Agency PE ...................... 194

8.3.9.3 Roberts on the Agency PE ............................................ 195

8.3.9.4 Other views .............................................................. 195

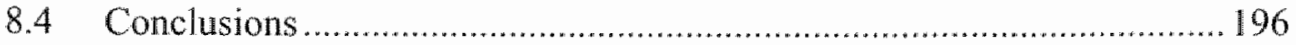




\section{Practical Applications}

9.1 Introduction............. 199

9.2 The Commissionaire Structure in General .......................................... 199

9.3 Subpart F advantage............................................................... 201

9.4 The Exclusive Commissionaire ....................................................... 203

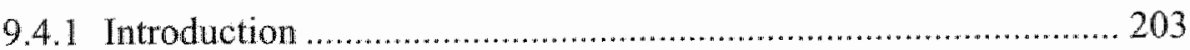

9.4.2 The Commissionaire According to the OECD and UN Model .... 203

9.4.3 The Altered OECD Commentary ............................................. 205

9.4.4 The Legal Aspects of the Dutch Commissionaire ....................... 206

9.4.5 The Subsidiary Company as an Exclusive Commissionaire ........ 208

9.4.5.1 Introduction ............................................................. 208

9.4.5.2 Article 5, Paragraph 7, OECD Model........................... 208

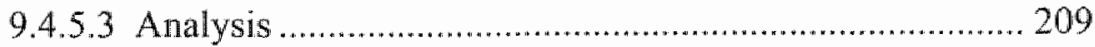

9.4.5.4 Conclusions ........................................................ 211

9.4.6 The Transformation of a Buy-Sell Subsidiary into

a Commissionaire ............................................................... 21]

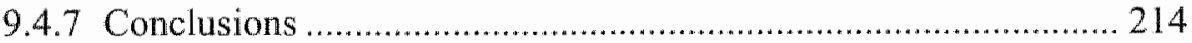

9.5 Electronic Commerce and the Agency PE Concept ............................ 214

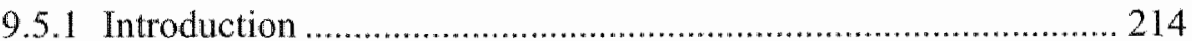

9.5.2 The General PE Concept ................................................... 215

9.5.3 The Agency PE and Internet Transactions ................................ 217

9.5.4 The Provider as an Agency PE? .............................................. 218

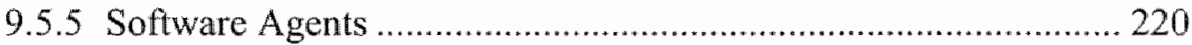

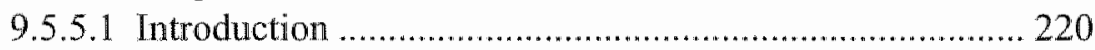

9.5.5.2 Software Agents and the Agency PE Concept................ 220

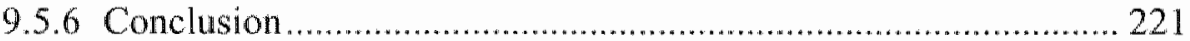

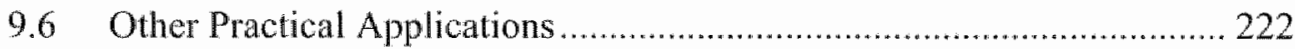

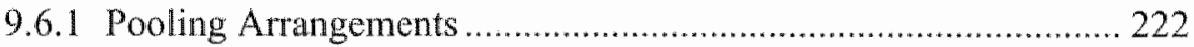

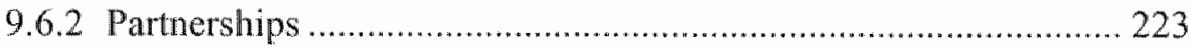

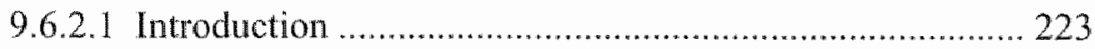

9.6.2.2 Mutual Agency ........................................................ 225

9.6.2.3 General or Limited Partner ............................................. 226

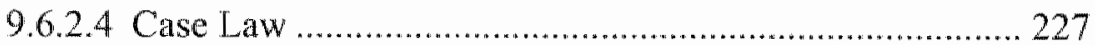

9.6.2.4.1 US Case Law................................................................ 227

9.6.2.4.2 Dutch Case Law ........................................................ 227

9.6.2.4.3 Belgian Case Law ..................................................... 228

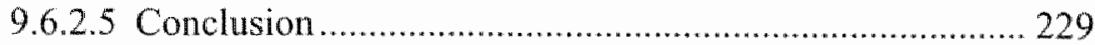

9.6.3 The Insurance Agent ............................................................ 230 


\section{Allocation of Profits}

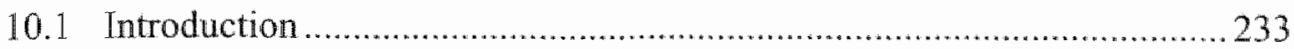

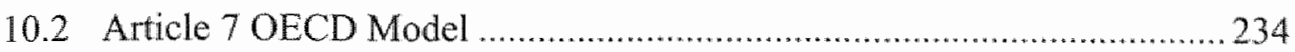

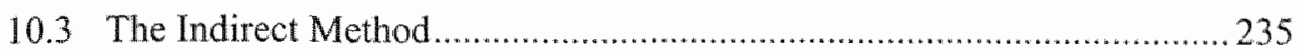

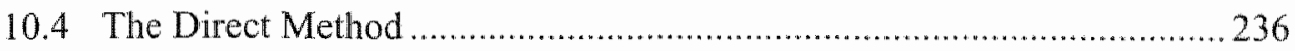

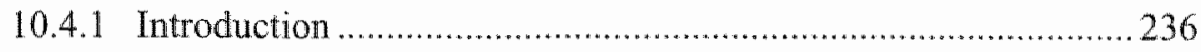

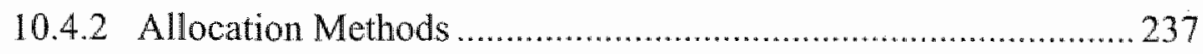

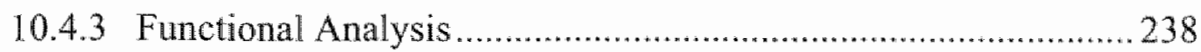

10.5 The Agency PE and the Allocation of Profits ..................................... 239

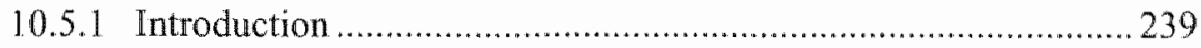

10.5.2 Independent Dealer or Commission Agent ............................. 240

10.5.3 Different Opinions............................................................ 241

10.5.4 Allocation Methods ............................................................ 242

10.5.4.1 Cost-Plus Method .................................................. 242

10.5.4.2 Resale-Minus Method ............................................ 243

10.5.4.3 The Commission or Fee Method and the

Independent Dealer Method ........................................ 244

10.6 Example of Application of the Direct Method ....................................... 245

10.7 The Stripped Buy and Sell Subsidiary .............................................. 248

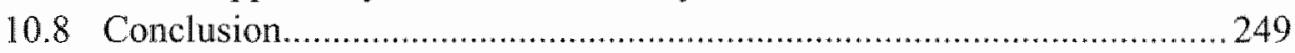

\section{Summary and Conclusions}

11.1 The Historical Development of the Agency PE

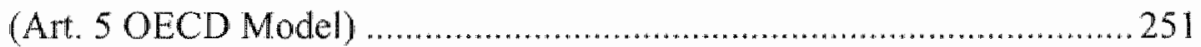

11.1.1 The Dependent Agency Clause ..............................................251

11.1.2 The Independent Agency Clause ..............................................253

11.2 A Comparison Between Germany, the UK, the US and the Netherlands 256 11.2.1 Domestic Law ................................................................. 256

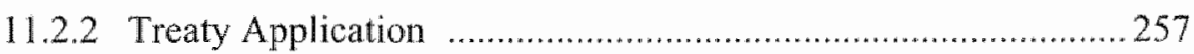

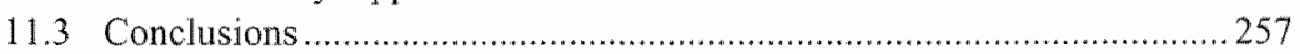


Samenvatting

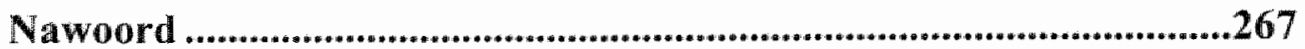

Appendix .......................................................................................269

Includes quotes that were used in the thesis in their original language

Bibliography. .273

League of Nations Publications .281

Curriculum Vitae .283 


\section{Abbrevations}

\begin{tabular}{|c|c|c|}
\hline Abbreviation & Country & Mearing \\
\hline Abs & Germany & Absatz (paragraph) \\
\hline $\mathrm{AO}$ & Germany & Abgabeordmung \\
\hline B. & The Netherlands & Beslissingen in belastingzaken (tot 1953) \\
\hline BFH & Germany & Bundesfinanzhof \\
\hline $\mathrm{BGB}$ & Germany & Bundesgesetzbuch (German Civil Code) \\
\hline BNB & The Netherlands & Beslissingen in belastingzaken (vanaf 1953) \\
\hline BStBI & Germany & Bundessteuerblatt \\
\hline BT & Germany & Bundestag \\
\hline$B V$ & The Netherlands & Besloten vennootschap \\
\hline $\mathrm{CA}$ & United Kingdomr & Court of Appeal \\
\hline DTC & & Double Taxation Convention \\
\hline EStG & Gemmany & Einkommensteuergesetz \\
\hline EStR & Germany & Einkommensteuer-Richtinien \\
\hline EU & & European Union \\
\hline $\mathrm{ExCh}$ & United Kingdons & Exchequer Chamber \\
\hline FED & The Netherlands & Fiscaal weekblad FED \\
\hline Geo & United Kingdom & King George the Fifth \\
\hline $\mathrm{HC}$ & United Kingdon. & High Court \\
\hline $\mathrm{HCB}$ & Germany & Handelsgesetabuch \\
\hline $\mathrm{HL}$ & United kingdom & House of Lords \\
\hline ICCAKK & The Netherlands & Intemationale Kamer van Koophandel \\
\hline $\mathrm{IRC}$ & United States & Internal Revenue Code \\
\hline IWB & Germany & Internationale Wirtschafts-Briefe \\
\hline $\mathrm{KB}$ & The Netherlands & Koninklijk Besluit \\
\hline K.B. & United Kingdom & Kings Bench Division \\
\hline $\mathrm{KStG}$ & Germany & Körperschaftsteuergesetz \\
\hline LON & & League of Nations \\
\hline OECD & & Organisation for Economic Cooperation and Developmen! \\
\hline OEEC & & Organisation of European Economic Cooperation \\
\hline ple & United Kingdom & Public limited company \\
\hline Q.B. & United kingdom & Queens Bench, U.K. High Court \\
\hline RStBI & Germany & Reichsteuerblat \\
\hline RFH & Germany & Reichfinanzhof \\
\hline StAnpG & Germany & Steueranpassungsgesetz \\
\hline Stb. & The Netherlands & Straatsblad \\
\hline $\mathrm{TC}$ & United Kingdom & Tax Cases \\
\hline TVVS & The Nelherlands & Tijdschrift voor verenigingen en stichtingen \\
\hline UK. & & United Kingdom \\
\hline UN & & United Nations \\
\hline US & & United States \\
\hline Viz. & & Namely (Lat, videlicet) \\
\hline$V-N$ & The Netherlands & Vakstudie Nieuws \\
\hline WER & The Netherlands & Weekblad voor fiscaal recht \\
\hline
\end{tabular}





\section{CHAPTER}

\section{Introduction}

The agent as a permanent establishment is a somewhat obscure area of international tax law and no extensive study has been produced on this subject, making it a great challenge for a scholar. However, the relevance of such a study is evident as tax practitioners all over the world - or at least in all of the OECD countries struggle - with the same problems concerning elements of the agency concept. This study is prompted by Article 5 (5) and (6) of the OECD Model Treaty. Because this treaty is indeed a model treaty, it is very relevant and essential to analyse to what extent Agency PE provisions are included in bilateral tax treaties. The Agency PE concept can also be found in many domestic tax laws. The basis af my research is the analysis of domestic and treaty application of the Agency PE concept in a number of countries: Germany, the United Kingdom, the United States and the Netherlands. Where relevant, the country-specific analysis will start with a historical analysis of the Agency PE concept in domestic and/or treaty provisions, as the historical analysis is absolutely vital for a proper understanding of the current Agency PE concept. The range, content and application of the Agency PE concept in domestic tax law and in the bilateral treaties of each country will be analysed.

Because agency is a legal phenomenon, I will start this study (in Chapter 2) with a legal analysis of the law of agency according to common and civil law. Because the US and UK have their legal systems based on common law, a common analysis is necessary. Meanwhile, Germany and the Netherlands have a legal system based on civil law. This chapter also includes a description of the broker and commission agent according to both legal systems.

Chapters 3-4 discuss the Agency PE concept within four countries. Chapter 3 is specifically dedicated to the German Agency PE concept, and domestic legislation and treaties are analysed from the late $1800 \mathrm{~s}$ until now. Chapter 4 concerns itself with the United Kingdom Agency PE concept, including a study of its historical development. Chapter 5 concerns the Agency PE concept in the United States, and chapter 6 as it applies to the Netherlands. 
Following this country-specific approach, Chapter 7 contains a study of the international treaty developments of the Agency PE concept, and it discusses and analyses the work of the League of Nations, the International Chamber of Commerce and the OECD. In Chapter 8, I define the current Agency PE definition based upon the findings in previous chapters. Chapter 9 discusses and analyses some major practical Agency PE applications, such as the commissionaire structure, pooling arrangements and partnerships. In this chapter, an analysis of whether e-commerce has implications on the current Agency PE concept is provided. In Chapter 10 the allocation of profits of the Agency PE is approached and discussed. Finally, Chapter 11 includes my conclusions based upon a summary of this study.

I have to acknowledge to the work of Arvid A. Skaar. His extensive study of the permanent establishment, and especially part five of this study entitled "Agencies", proved to be a good starting point.' A lot of groundwork has been done by Sidney I. Roberts in his two articles in Intertax. ${ }^{2}$ His historical analysis proved to be of great value for this study. Especially his very critical approach inspired me enormously. John F. Avery Jones and David A. Ward also produced very valuable material through their extensive and thorough research which was published in the article "Agents as Permanent Establishments under the OECD Model Tax Convention". 3

In Dutch tax law the term vaste vertegenwoordiger ("fixed or permanent representative") is used to define the agent as a permanent establishment. The Dutch terms originated from German tax law, where the ständige Vertreter is "the agent as a PE". A new term is now frequently used in Germany, namely the Vertreter-Betriebsstätte or "the agency permanent establishment". Meanwhile, in the US and UK the term "permanent establishment" is used for all forms of PE's: the physical PE (Art. 5, para. 1-2, OECD Model), the construction PE (Art. 5, para.

1.A. Skaar, Permanent Establishment, Erosion of a Tax Treaty Principle, Series on International Taxation, (Kluwer Law International, Deventer, 1991).

2 S. I. Roberts, "The Agency Element of Permanent Establishment: the OECD Commentaries from the Civil Law View', Parts One \& 'Two, Intertax 1993/9 \& 1993/10.

3 J.F. Avery Jones \& D.A. Ward, 'Agents as Permanent Establishments under the OECD Model Tax Convention', Europeon Toxalion, May 1993.

4 L. Fischer, Besteuerung wirtschaftlicher Aktivitäten won Ausländern in Deutschland, Köln 1995, page 36 . 
3, OECD Model) and the Agency PE (Art. 5, para. 5, OECD Model). In this study I will use the latter term "agency permanent establishment" (Agency PE).

\subsection{GENERAL CONCEPT}

Art. 5, para. 5 of the 1997 OECD Model Tax Convention (hereafter "OECD Model") contains the main elements of the Agency PE:

"5. Notwithstanding the provisions of paragraphs 1 and 2 , where a person - other than an agent of an independent status to whom paragraph 6 applies - is acting on behalf of an enterprise and has, and habitually exercises, in a Contracting State an authority to conclude contracts in the name of the enterprise, that enterprise shall be deemed to have a permanent establishment in that State in respect of any activities which that person undertakes for the enterprise, unless the activities of such person are limited to those mentioned in paragraph 4 which, if exercised through a fixed place of business, would not make this fixed place of business a permanent establishment under the provisions of that paragraph."

From this paragraph, certain baseline conditions and core elements of the Agency PE concept can be derived:

(1) a person acting on behalf of;

(2) an authority to conclude contracts in the name of;

(3) no agent of independent status.

The term "agent" would seem to refer to the legal concept of agencies. The element of "acting on behalf of" would imply an economic dimension: the agent acts for the account and risk of the principal. The concluding of contracts "in the name of" a principal is a typical civil law element of the legal concept of agency. These different approaches to this article justify the question: is the Agency PE concept based on an economic or legal concept? My research will focus on this question.

More details about the independent agent can be found in Art. 5, para. 6, of the OECD Model: 
"6. An enterprise shall not be deemed to have a permanent establishment in a Contracting State merely because it carries on business in that State through a broker, general commission agent or any other agent of an independent status, provided that such persons are acting in the ordinary course of their business."

Clearly the broker and general commission agent are considered to be agents of an independent status. Para. 6 finally exempts a third category of agents from the PE status, namely "any other agent of an independent status". All agents of independent status must be "acting in the ordinary course of their business", in order to be exempi from the Agency PE status. Because para. 6 exempts entrepreneurs from having an Agency PE if their agent is considered to be an independent agent, case law often revolves around this paragraph. I will focus on the birth of this provision and analyse the meaning and range of this exemption rule. 


\section{Agents in Commercial Law}

\subsection{INTRODUCTION}

Article 5, paragraph 5, of the OCE Model uses the phrase "authority to conclude contracts in the name of the enterprise". If an agent has authority to conclude contracts in the name of the enterprise, the enterprise must have given the agent some sort of legal authority to act on its behalf. The legal aspect of the Agency $\mathrm{PE}$ definition is the topic of discussion in this chapter.

If an agent acts, he acts on behalf of the person (individual or company) he represents, the principal. In other words, the economic risks are borne by the principal. The agent, in general, will receive a commission for the work he has accomplished. Legally, the relationship is more difficult. In an agency situation, there are several relationships, which have to be considered when reviewing the legal implications. The first relationship is that between the principal and the agent, the internal relationship. In the agreement between the principal and the agent, the rights and duties of both parties are laid down. The second legal relationship is that between the agent and the third party, usually a customer of some kind. Thirdly, the relationship between the principal and third party. This relationship is important (the external relationship) for determining the liability of contract: who is bound by the contract and thus who can sue or be sued under it, the agent or the principal.

These questions of liability are applied differently in countries all over the world. However, one of two main systems can be recognised in each country: common law and civil law. Therefore, this analysis will start with the common law view on agency followed by the civil law view. The common law agency issue under discussion is the law of agency. Its civil law counterpart is the law of representation. The last part of the chapter is dedicated to a special analysis of the civil and common law conceptions of "brokers" and "commission agents". The common law analysis is restricted to the US and UK perspective. The civil law analysis will primarily be limited to German and Dutch law. 


\section{THE LAW OF AGENCY IN COMMON LAW}

\subsubsection{Introduction}

The leading principle of agency", according to the common law view, is "qui facit per alium, facit per se", or "he who acts through another, acts himself". The agency is defined as a fiduciary relationship which results when one person allows another to act on his behalf and subject to his control and this other person consents to act in this way. ${ }^{2}$ A fiduciary is a person who acts primarily for the benefit of another.

In the principal versus agent relationship, the agent performs the principal's business and, therefore, the principal should only be in a position to determine how his business is to be conducted. ${ }^{3}$ The word "agency" to a common lawyer refers in general to a branch of the law under which one person, the agent, may directly affect the legal relations of another person, the principal, as regards other persons, called third parties. The agent is said to have the principal's authority to perform these acts on his behalf which when done are in some respect treated as the principal's acts. ${ }^{4}$ If the agent enters into a contract with a third party on behalf of his principal, that contract is regarded by law as having been made by the principal himself. ${ }^{5}$ Where a contract of agency exists, the agent can make contracts on the principal's behalf which are binding on the principal and the third party. This depends, however, on the scope of the agent's explicit or implied authority. Another important aspect in this regard is the concept of apparent authority.

In the next section, I will discuss these kinds of authority. These are important issues when considering whether the principal is liable for the contracts concluded by his agent. I will discuss the common concept of an undisclosed principal. A principal can, subject to exceptions, be liable for the contract concluded by the agent even when the principal is undisclosed, that is, where

1 F.M.B. Reynolds, Bowstead on Agency, 15th ed. (Sweet \& Maxwell, London 1985).

2. According to Paragraph 1, Restatement of Agency, Restatement of the Law, Second, Agency 2d, Volume 1, (American Law Institute, Washington, 1957), p. 7.

3 H.G. Reuschlein \& W.A. Gregory, Handbook on the Law of Agency and Partnership (West Publishing Co., St. Paul, Minn., 1979), p. 12.

4 F. M.B. Reynolds, op cit., n. 1, p. 1.

5 P.S. Atiyah, An imtroduction to the Law of Contract, 4th ed., (Clarendon Press, Oxford, 1989), p. 380 . 
the third party is unaware of the principal's existence. ${ }^{6}$ It is also possible that the third party is aware that he is dealing with an agent, and so with the existence of a principal, but doesn't know the actual name of the principal. This is referred to in the literature as the unnamed principal or partially undisclosed principal.

\subsubsection{Explicit, Implied and Apparent Authority}

The agent's authority can be divided into real (also referred to as "actual") authority and apparent authority. Authority is real if the principal notified the agent. ${ }^{7}$ Real or actual authority to contract may be explicit or implied. In the typical case of explicit actual authority, authority is conferred on an agent by agreement with the principal. This authority enables the agent to bind the principal by acts done within the scope of that authority. The extent of the agent"s actual authority will depend upon the true construction of the words of his appointment. ${ }^{8}$ If the principal wishes to create real authority in the simplest and clearest possible manner, he will give the agent a written power of attorney which stipulates precisely what the agent may do. ${ }^{9}$ In the case of explicit actual authority, the principal is bound to the contracts concluded by the agent.

Implied authority is used in many different senses so that it has no precise or widely accepted meaning. Authority is implied when it is inferred from the conduct of the parties and the circumstances of the case..$^{10}$ Implied agency is actual agency and the difference between it and explicit agency is mainly one of how the agency relationship is proved to exist. ${ }^{11}$ The term "implied" means hardly more than that we find no proof of explicit authorisation but think the appearances justify a finding that in some manner the agent was authorised to do what he did. It has been said that "implied authority is actual authority circumstantially proven from the facts and circumstances attending the transaction in question and includes such incidental authority as is necessary, usual and proper as a means of effectuating the purpose of the employment". ${ }^{2}$

6 P.J. Cooke \& D.W. Oughton, The Comman Law of Obligations, 2nd ed. (Butterworths, London, 1993), p. 95.

7 Restatement, 7: "Authority is the power of the agent to affect the legal relations of the principal by acts done in accordance with the principal"s manifestations of consent to him."

8 B.S. Markensis \& R.J.C. Munday, Am outline of the Law of Agency, (Butterworths, London, 1992), p. 16.

9 H.G. Reuschlein \& W.A. Gregory, Handbook on the Law of Agency and Pat fnership, p. 34.

10 Lord Denning MR in Hely-Hutchinson ws. Brahead Ltd (1968) I QB 549 at 583.

11 Dobbs vs. Zink, 290 Pa. 243, 138 A. 758, 759 (1927).

12 Steven ws. Frost, 140 Me. 1, 32 A. 2 d 164 (1943). 
The implied authority of an agent extends to all subordinate acts which are necessary or ordinarily incidental to the exercise of his explicit authority. A person may appear to have given authority to another, and acts within this apparent authority may effectively bind him to the third party. This authority may create an agency relationship where none already exists, or it may extend an existing relationship. ${ }^{13}$ It does not, however, extend to acts which are outside the ordinary course of the person's business, or which are neither necessary mor incidental to his explicit authority. ${ }^{1-4}$

The concept of apparent authority, or ostensible authority as it is usually called, is really an application of the principle of estoppel. Agency by estoppel arises where one person has acted so as to lead another to believe that he has authorised a third person to act on his behalf. Consequently, this other person, believing this to be the case, enters into transactions with the third person within the scope of this ostensible authority. Thus, where one person explicitly or implicitly represents another to have authority to act on his behalf, so that a third party reasonably believes him to possess that authority and deals with him in reliance on the representation made, the person making the representation will be bound to the same extent as if actual authority had in fact been conferred. He is estopped from denying the ostensible authority which he has created. ${ }^{15}$ There are three important conditions attached to apparent authority. First, the representation must be made by or with the authority of the principal. Secondly, subject to certain exceptions, the third party must rely on a representation of the agent's authority to act as agent; the concept cannot apply where the third party does not know or believe him to be an agent, as in the case of the undisclosed principal. Thirdly, the agent's lack of authority must be unknown to the third party. ${ }^{16}$

\subsubsection{The Concept of the Undisclosed Principal}

A principal is not liable through any bill of exchange or negotiable instrument unless he has signed it, but if it is signed by an agent acting under his authority, he will be liable. In fact, the only substantial limitations upon the principal's rights and liabilities are those which are imposed in the case of an undisclosed principal, in other words, where the fact that a person is acting as an agent for

13 Halsbury 's Laws of England, 4th ed. (Butterworths, London, 1990), p. 37.

14 lbid., p. 42

15 A.G. Guest, Anson's Law of Contract, 26th ed. (Clarendon, Oxford, 1984), p. 534

16 lbid., p. 534 
another person is not disclosed to the third party at the time that the contract is made. ${ }^{17}$

If the third party is not aware that the person with whom he concludes a contract is in fact acting on behalf of a principal, an undisclosed agency exists. The agency is undisclosed because the principal is undisclosed. The concept regarding this issue is called the concept of the undisclosed principal because the principal primarily determines the existence of an agency. When an agent concludes a contract on behalf of an undisclosed principal, the general rule is that, provided the agent acted within the scope of his authority, the undisclosed principal may subsequently provide evidence to show that he was the actual principal in the transaction and he may sue and be sued under the contract concluded by his agent. ${ }^{18}$ On the other hand, when the third party discovers that his contracting party acted as an agent on behalf of an undisclosed principal, he is entitled to elect whether he will treat the principal or agent as the party with whom he dealt. ${ }^{19}$

This concept is generally recognised but criticised. It contravenes the fundamental principles of the law of contract. Ordinary agency, where the principal is disclosed, can be reconciled with the common law concept, that only parties to a contract can acquire rights and liabilities under it, on the grounds that the principal is really a party to the contract (either in substitution for or in addition to the agent). In this situation, the agent may be regarded as being only an instrument by whose hand and act the principal contracts. But, when the third party does not know of the existence of the (undisclosed) principal, the same cannot be said of this form of agency. The fiction of the identity of principal and agent is inapplicable in this context. ${ }^{20}$

If a person appears to be contracting only for himself, but in fact is acting for a principal, it seems logical (certainly based upon rules of contract law) that the agent is party to the contract. The third party clearly intended to deal with the agent alone. However, some two hundred years ago, the courts began to hold that the principal could sue as a party to the contract and this has been the rule ever since in order to protect the principal or the third party in certain circumstances from the harshness of the general principles of contract law. It is not unfair to the principal to impose liability upon him for an authorised

17 Ibid., p. 551.

18 B.S. Markesinis \& R.J.C. Munday, op cit., n. 8, p. 130.

19 A.G. Guest, op cit., n. 15 , p. 560.

20 G.H.L. Fridman, The Law of Agency, (Butterwoths, London, 1983), p. 222. 
contract, since it was his business which was being done and so there is no reason why the ordinary rulle that the principal is responsible for authorised acts should not be invoked. ${ }^{21}$

The principal's right to intervene on his agent"s contract is limited in certain circumstances. In Fred. Drughorn Ltd. vs. Rederikatiebolaget Transatlantic ${ }^{22}$, the ship owners and Lundgren, as charterer, signed a charter party. A charter party is a written contract by which a person (the charterer) hires from a ship owner, in return for the payment of freight, the use of his ship or part of it for the carriage of goods by sea. Lundgren was in fact acting for an undisclosed principal. The undisclosed principal claimed that he was entitled to sue on the basis of the charter party. The House of Lords held that evidence that the agent contracted on behalf of an undisclosed principal was admissible, provided that the evidence did not contradict the terms of the contract. This was the first limitation on a principal's right to intervene in his agent's contract. An example of such a contradiction was given by Viscount Haldane in this case:

"The question is not before us now, but I see no reason to question that where one has the description of a person as the owner of property, and it is a term of the contract that he should contract as owner of that property, one cannot show that another person is the real owner."

This, more or less, points to the second limitation on a principal's right to intervene on his agent's contract: namely, the identity of the parties. The principal is not entitled to sue on contracts where the third party clearly intended only to contract with the agent and with no one else. The courts will also not permit the principal to sue the third party where the latter's contract with the agent is one which the third party entered into relying upon the agent's personal skills or solvency. ${ }^{23}$ An example can be found in the case of Said vs. Butt. ${ }^{24}$ Said wished to see a play on its first night at the Palace Theatre. He knew that the theatre owners would not sell a ticket to him because of previous differences between them over the production of one of his operas. He therefore asked a friend to buy a ticket for him. When he got to the theatre, Butt (the managing director) refused to allow him to proceed to his seat. Said brought an action for damages against Butt for wrongfully inducing the owners of the theatre to commit a breach of contract for the sale of the ticket. The action

21 H.G. Reuschlein \& W.A. Gregory, id. at note 7.

22 Fred. Drughory Lid. vs. Rederika Thansatlantic (1919) A.C. 203 (HL).

23 B.S. Markesinis \& R.J.C. Munday, op cit. N. 8, p. 136.

24 Said ws. Butt (1921) 124 L.T. 416. 
failed. The court of the King's Bench Division held that no contract existed on which Said could have sued the owners of the theatre because the personal element in the contract (the purchase of the ticket) was strikingly present, and the owners had made it clear that in no circumstances would they contract with Said, especially as it was the first performance of the play. ${ }^{25}$ Said could not sue because the third party (Butt) only wanted to contract with Said's friend, certainly not with Said, who was the undisclosed principal in this case.

In conclusion, if the agent does not disclose the existence of a principal, he contracts with the third party as if he were the principal. In this situation:

1 the undisclosed principal has, subject to the two limitations, the right to intervene and claim, and if necessary sue, the third party directly. If he makes use of this right, he renders himself personally liable to the third party, and

2 the third party, after having discovered the principal, has a choice. He may elect to hold liable and sue either the principal or the agent. ${ }^{26}$

The choice of the third party is a definitive one. In Kendall vs. Hamilton $(1879)^{27}$, it was made perfectly clear that if a third party obtains judgement against the agent, he cannot then sue the principal (and vice versa). The reason for this rule was pointed out by Lord Caims in Kendall vs. Hamilton:

"But the reasons why this must be the case are, I think, obvious. It would be clearly contrary to every principle of justice that the creditor who had seen and known, and dealt with, and given credit to the agent, should be driven to sue the principal if he does not wish to sue him, and, on the other hand, it would be equally contrary to justice that the creditor, on discovering the principal, who really has had the benefit of the loan, should be prevented from suing him if he wished to do so. But it would be no less contrary to justice that the creditor should be able to sue first the agent and then the principal, when there was no contract, and when it was never the intention of any of the parties that he should do so. Again, if an action were brought and judgement recovered against the agent, he, the agent, would have a right of action for indemnity against his

25 E.R. Hardy Ivamy \& P. Latimer, Casebook on Commercial Law, 3rd ed., (Butterworths, Landon, 1979) p. 146.

26 C.M. Schmitthoff \& D.A.G. Sarre, Chanlesworth's Mercamile Law, 14 th ed., (Stevens \& Sons, Londan, 1984), p. 243.

27 Kendall vs. Hamilton (1879) 41 L.T. 418. 
principal, while, if the principal were liable to be also sued, he would be vexed with a double action. Further than this, if actions could be brought, and judgements recovered, first against the agent and afterwards against the principal, you would have two judgements in existence for the same debt or cause of action; they might not necessarily be for the same amounts, and there might be recoveries had, or liens and charges created, by means of both, and there would be no mode upon the face of the judgements, or by any means short of a fresh proceeding, of showing that the two judgements were really for the same debt or cause of action, and that satisfaction of one was, or would be, satisfaction of both."

It was a purely practical reason for not granting the third party the option to sue both agent and principal. There would in that case be two different court rulings on the same issue which would give rise to all sorts of practical problems regarding the execution of both court rulings.

\subsubsection{The Unnamed Principal}

An agent may inform the third party that he is acting on behalf of a principal but he may not disclose the principal's identity. The principal is then said to be unnamed, sometimes also referred to as a partially disclosed principal.

The principal and third party have the same legal rights and liabilities as if the principal was named. ${ }^{28}$ The only difference is the position of the agent. An agent is, in this case, not personally liable under the contract he makes. In Universal Steam Navigation Co. Ltd. vs. James McKelvie \& Co. (1923), it was decided that where an agent indicates that he is contracting as an agent, he cannot be held liable under the contract. ${ }^{29}$

In Benton vs. Campbell, Parker \& Co. Ltd., an auctioneer sold a car at an auction on behalf of an unnamed principal. The buyer discovered that it was already subject to a hire purchase agreement, so he sought to hold the auctioneer personally liable under the contract of sale. The court of the King's Bench Division held that where an auctioneer sells specific goods for an unnamed principal, he cannot normally be held liable if the principal has no title to them. ${ }^{30}$

28 R. Lowe, Commercial Law, 6th ed., (Sweet Maxwell, London, 1983), p. 48.

29 Universal Steam Namigation Co. Ltd. vs. James McKelvie \& Co. (1923) 129 L.T. 395; also Gadd ve. Houghton \& Ca. (1876) 35 L. T. 222.

30 Benton vs. Campbell, Parker \& Co. Ldd. (1925) 2 K.B. 410; E. R. Hardy Ivamy \& P. Latimer, Casebook on Commercial Law, p. 155. 


\subsubsection{Summary}

\begin{tabular}{|llcc|}
\hline Agency cases & $\begin{array}{c}\text { Liability principal } \\
\text { vs. third party }\end{array}$ & $\begin{array}{c}\text { Liability agent } \\
\text { vs. third party }\end{array}$ \\
\hline 1 & Disclosed principal & Yes & No \\
\hline 2 & Undisclosed principal & Yes & Yes \\
\hline 3 & Unnamed principal & Yes & No \\
\hline
\end{tabular}

The liability works both ways. For example, if the third party holds a disclosed principal liable on the basis of the contract concluded by his agent, the third party is obviously liable under the same contract on the basis of his role as the other contracting party.

\subsection{THE LAW OF AGENCY ACCORDING TO CIVIL LAW}

\subsubsection{Introduction}

In civil law, the legal agency concept is included in several legal concepts; whereas in common law, the law of agency comprises the main rules. One typical civil law concept is mandatum. We are apt to think of mandatum in terms of agency, and the word agency is sometimes employed to translate the word mandatum. However, this is incorrect. Under contract law, agency implies a contractual relationship established between one person, termed the "principal" and a third party, by another person termed the "agent" who acts as intermediary. In English Law, at least, the topic "Principal and Agent" is mainly concerned with this relationship, though also with the relationship between the principal and agent. However, a mandate is essentially a contract of employment and its rules are concerned only with the reciprocal rights and duties of the mandator on the one hand and the mandatarius on the other. ${ }^{31}$

Where a mandate determines the rights and duties between the principal and agent, the German concept of Vollmacht is the agent's power of representation. This distinction is also made in Dutch law. The Dutch volmacht is the authority of the agent to conclude contracts in the name of his principal. The duty of the

31 R.W. Lee, The Elements of Roman Law, (Sweet \& Maxwell, London, 1956), pp. 334-336. 
agent to act according to the volmacht can result directly from law or from agreement (such as lastgeving). ${ }^{32}$

Within the framework of this study, the agent's power of representation is obviously an important area for study.

The German Civil Code (Bürgerliches Gesetzbuch) addresses the agent's power of representation (Stellvertretung) in the general part of the code (paragraphs 164-181). The general rules dealing with the power of representation are applicable to powers granted by law as well as to powers created by a jural act of the principal. ${ }^{33}$

The main principle is formulated in $\S 164$ of the German Civil Code:

"Eine Willenserklärung, die jemand innerhalb der ihm zustehenden Vertretungsmacht im Namen des Vertretenen abgibt, wirkt unmittelbar für und gegen den Vertretenen."

This provision states that the agent who has the power to represent someone can give a declaration of intent in the name of the one he represents. This declaration of intent (Willenserk]ärung) ${ }^{34}$ directly works for and against the represented party, or in legal terms binds the principal (the represented party) to the third party.

According to Dutch law, the agent who is authorised to act in the name of his principal must actually name his principal, otherwise the agent himself will be liable under the contract. ${ }^{35}$ The agent who acts in the name of his principal directly binds his principal. It is essential that the agent makes clear to the third party that he acts on behalf of someone else. ${ }^{36}$

32 The rules of wolmacht can be found in Book 3, ss $60-79$ Dutch Civil Code (Burgerlijk Wetboek).

33 R.B. Schlesinger, Comparative Law, (The Foundation Press, New York, 1980), p. 723.

34 A declaration of intent is a statement of parties showing their intentions. A contract is considered to be a declaration of intent.

35 According to Art. 67, Book Three, Burgerlijk Wetboek.

36 G. Pottschmidt \& U. Rohr, Privatrecht fiu den Katufmann ("Private law for the businessman") 8th ed., (Munchen 1990), page 91 . 


\subsubsection{Direct Representation}

If the agent acts in the name of his principal, he legally binds his principal. Civil law calls this type of representation "direct representation" (offene Stellvertretung). Representation is present if the agent recognisably acts on someone else's behalf. ${ }^{37}$ If the agent concludes contracts in the name of his principal, he thus acts recognisably on behalf of his principal and so is directly representing his principal. As in common law, the agent must be authorised to conclude contracts in the name of his principal. Schmidt states: "Wer mit Vertretungsmacht erkennbar 'im Namen des Unternehmens' handelt, berechtigt und verpflichtet den Unternehmensträger." ${ }^{38}$ According to Schmidt, decisions are made in view of whether the represented enterprise or the agent were deemed to be the contracting partner. If the agent acts in the name of the principal, the intent of the contracting parties is that the principal is, in fact, one of the contracting parties and so is liable under the contract and not the agent.

\subsubsection{Indirect Representation}

The type of representation known as indirect representation is in fact no representation. The term "indirect" implies that the acting person does not pretend to act on behalf of someone else but implies that he intends to legally bind himself to the third party. ${ }^{3.9}$

If for example $B$ concludes a contract in his own name with $C$, but $B$ acts silently on behalf of $A, B$ does not represent $A$ with regard to $C$. In this case there are two legal contracts: one between the "agent" $B$ and the third party $C$ and another between principal $\mathrm{A}$ and agent $\mathrm{B}$. The essential fact is that, in this case, there is no legal liability between principal $\mathrm{A}$ and the third party $\mathrm{C}$.

A typical example of indirect representation is the civil law commissionait. A commissionair is a person who acts on behalf of someone else but concludes contracts in his own name. The commissionair's principal is not liable for the contract with the third party.

37 A. Pitlo, De benoende overeenkomsten, 8thed. (Gouda Quint, Arnhem, 1979), p. 347.

38 K. Schmidt, Hondelsrecht, 4th ed. (Heymanss, Köln, 1994), p. 121.

39 C. Asser, Ventegenwoordiging en rechtspersoon, 6th ed. (Tjeenk Willink, Zwolle, 1985), p. 84. 
In the case of direct representation, that is when the agent is acting in the name of the principal, only one obligatory agreement ${ }^{40}$ is present: an agreement between the principal and the third party. For indirect representation, that is when the agent acts in his own name, there are two obligatory agreements present: firstly, the agreement between the principal and the agent and, secondly, between the agent and the third party. In the case of indirect representation, the agent does not bind his principal.

\subsubsection{Summary}

\begin{tabular}{|llcc|}
\hline & Agency cases & Liability principal & Liability agent \\
\hline 1. & Direct representation & yes & No \\
\hline 2. & Indirect representation & no & Yes \\
\hline
\end{tabular}

The common law counterpart of direct representation is the law of agency. Indirect representation according to civil law can be compared to the common law concept of the undisclosed principal. The concept of apparent authority is known in common law and civil law jurisdictions.

\subsection{TIIE BROKER}

\subsubsection{According to Common Law}

In Fowler versus Hollins, judge Brett J. defined a broker as:

"an agent employed to make bargains and contracts between persons in matters of trade commerce and navigation. Properly speaking, a broker is a mere negotiator between other parties. He himself has no possession of the goods, no power actual or legal of determining the destination of the goods, no power or authority to determine whether the goods belong to buyer or seller or either., 41

According to the quote above, a broker primarily negotiates contracts on behalf of his principal. A broker is a person who acts as a go-between for buyers and sellers of goods which he may never see. Brokers can negotiate different kinds

40. An obligatory agrement is an agreement which creates rights and obligations for all the contracting partners concerned.

41 Fowler Hollins (1872) LR 7 QB 616 at 623. 
of contracts, for example stockbrokers deal with the sale of stock or shares, insurance brokers arrange insurance policies, other brokers deal in the hiring of ships through charter parties (shipbrokers). ${ }^{42}$ A more recent growth area is that of the credit broker, whose function is to arrange credit for those who wish to purchase goods. ${ }^{4.3}$

Brokers who are members of the Stock Exchange or a commercial exchange or other similar institution have an implied authority to make their contracts subject to the rules of such an institution but beyond that they have no implied or presumed authority of any kind. Brokers are not liable for the failure of a third party to pay the price. ${ }^{44}$

In conclusion, a broker is an intermediary whose ordinary course of business is to negotiate and make contracts for the sale and purchase of goods and other property, of which he is not entrusted with the possession, ownership or control. $^{45}$

\subsubsection{According to Civil Law}

The Dutch broker (makelaar) is, according to article 62 Wetboek van Koophandel (Dutch Commercial Code), an officially sworn in person who intermediates in the realisation and conclusion of contracts in the name of his principal. The Dutch makelaar is an agent who acts in the name of his principal, not in his own name, and who the law presumes has the relevant authority. The makelaar is a broker who is a real agent in that he concludes contracts on behalf and in the name of the principal. ${ }^{46}$ The Dutch makelaar is sworn in by the district court (arrondissementsrechtbank) and is thus the only broker who may call himself makelaar. Other intermediaries who conduct the same business as the makelaar, but are not swom in, are not allowed to call themselves makelaar.

The German broker (Makler) differs from the Dutch makelaar in that he, by German law, has no authority to conclude contracts in the name of the principal.

42 There are also bill brokers, cotton brokers, diamond brokers, fruit brokers, hotel brokers, loading brokers, mortgage brokers and wool brokers.

43 G.H.L. Fridman, The Law of Agency, 5th ed (Butterworths, London, 1983), p. 37.

44 C.M. Schmithoff \& D.A.G. Sarre, Charlesworth's Mercamile Law, 14th ed. (Stevens \& Sons, London, 1984), p. 241.

45 F.M.B. Reynolds, op cit., n. 1, p. 11.

46 S.J.A. Mulder, Hoofdzaken waardepapieren en mssenpersonen, 2 nd ed. (Kluwer, Deventer, 1995), p. 65. 
In practice, however, they can conclude contracts if the principal grants them the authority, by means of a Vollmacht. ${ }^{47}$

In German trade business, the commercial broker (Handelsmakler) is frequently used. The general broker is called the Zivilmakler. The commercial broker is one who commercially undertakes the negotiation of agreements concerning commercial matters for other persons in exchange for commission, without being entrusted to do so permanently by contractual relationship (paragraph 93, German Civil Code). ${ }^{48}$ The broker is regarded as being independent.

\section{5}

\section{THE COMMISSION AGENT}

\subsubsection{According to Common Law}

Commission agents, according to English law, are agents employed for a variety of purposes, for instance, the sale and purchase of goods. The group includes estate agents, instructed to find a purchaser by the vendor of land, and forwarding agents, employed by manufacturers or private persons to arrange for the carriage of goods by land, sea or air carriers and to look after customs and other formalities. ${ }^{49}$

The estate agent has no authority to conclude a contract of sale but merely an authority to negotiate. The contract between principal and estate agent is a mere promise that the principal pays a commission when a specified event happens, in other words, the principal concludes a contract of sale with a third party who is in a position to carry out the terms of the contract. ${ }^{50}$ The commission merchant, a typical English type of commission agent, is a person appointed by a principal to deal (especially to buy) on his behalf, on the understanding that when dealing with the third party the agent will deal in his own name and not create any contractual privity for the principal. ${ }^{51}$ As between principal and agent, however, the relationship is one of agency, in other words, the agent does not promise to achieve a result but only to use his best endeavours, he is

47 K.H. Capelle \& C.W. Canaris, Handelsrecht, 19th ed. (Beck, München, 1980), p. 84.

48 M. Peltzer, J.J. Doyle, \& M.T. Allen, German Commercial Code, 2nd rev, ed. (O. Schmidt, Koin, 1993), p. 9.

49 Siater"s Mercantile Law, p. 134.

50 IT.R. Gibson, South African Mercawtile and Company Law, 5th ed., (Juta \& Company Ltd, Cape Town, 1983), p. 259.

51 Also the factor can have the implied authority to sell in his own name, according to Halsbuy's Laws of England, vol.1(2), page 46. 
normally remunerated by pre-arranged commission, he may not without disclosure take commission from the other party and he does not answer to his principal as seller or as buyer. ${ }^{52}$

US common law does not specifically define the commission agent. It does have a kind of commission agent, namely the independent contractor. This is a person who contracts with another to do something for him but who is not controlled by the other nor subject to the other's right to control with respect to his physical conduct in the performance of the undertaking. He may or may not be an agent. Examples of the independent contractor are brokers, factors, attorneys at law, auctioneers, selling agencies and collection agencies. ${ }^{53}$ What these various agents have in common is their remuneration, calculated on the basis of the value of the transaction which they have brought about, according to Slaters's Mercantile Law.

The agent's liability to third parties is important. The general rule is that the agent incurs no such liability and that he drops out once he has tied the knot between principal and third party. The common practice of some markets, however, has created the presumption that the agent for a foreign principal is personally liable in England as that agent is entitled to recoup from his principal. ${ }^{54}$ Under the International Air Transport Association's Cargo Sales Agency Rules, forwarding agents are personally liable for the charges of air carriers with whom they contract on behalf of their principals, and the same applies to their dealings with carriers by sea. ${ }^{55}$

\subsubsection{According to Civil Law}

A civil law commission agent, commissionair in Dutch and Kommissionär in German, is a frequently used type of intermediary. Their meaning and role is basically the same in the Netherlands and in Germany.

A commissionair is an intermediary who acts on behalf of his principal but concludes contracts in his own name. Usually the commissionair concludes purchasing agreements. The commissionair is liable under the contract that he concludes with the third party. The principal runs the risk of the contract which

52 F.M.B. Reynolds, op cit., n. 1, p. 6.

53 H.G. Reuschlein \& W. A. Gregory, Handbook on the Law of Agency and Parmership, (West Publ. Co., St. Paul, 1979), p.4.

54 Slater's Mercantile Law' p.134.

55 According to Slater's Mercantile Low. 
the commissionair concluded on his behalf. This risk, the acting "on behalf of", is at the expense of the principal through his payments made under the commission agreement. All benefits and damages are at the expense of the principal. $^{56}$

The Dutch Commercial Code used to have a special section of the law dedicated to the commissionair. On 1 January 1992, these special provisions were withdrawn. Since then, the law concerning the commissionair is mainly dominated by the rules of assignment (lastgeving) of the Dutch Civil Code. ${ }^{57}$ The commissionair is an agent without the power of representation, a typical example of civil law indirect representation. ${ }^{58}$

German law does contain a special provision concerning the Kommissionär. Paragraph 383 of the Handelsgesetzbuch (German Commercial Code) states:

"A commissionair is someone who professionally buys or sells goods or securities in his own name but on behalf of someone else. ${ }^{.59}$ [See Appendix, Quote 2 for original in German.]

Again, German trade practice developed a different type of Kommissionär, namely the Kommissionsagent. The Kommissionsagent binds himself, by contract, for a longer period of time to his principal. For the third party, generally the buyers, he is regarded as a "normal" Kommissionär. He acts in his own name. His relationship with his principal differs from the Kommissionär in that some aspects of the internal relationship are ruled by the provisions of the Handelsvertreter (commercial agent), mainly aspects concerning the duration of the contractual relationship between the Kommissionsagent and his principal. ${ }^{60}$

56 S.J.A. Mulder, Hoofdwaken wardepapieren en tussenpersonen, p. 69.

57 Articles 414-424, Book 7, Burgerlijk Wetboek.

58 H. de Groot \& P.A. Stein, Grondtrekken van het handelsrecht, 7th ed. (W.E.J. Tjeenk Willink, Deventer, 1996), p. 394.

59 Schlegelberger Handelsgesetzbuch, 5th ed. (Vahlen, München, 1977).

60 K.H. Capelle \& C.W. Canaris, Handelsrecht, p. 196. 


\section{SCHEDULE OF COMMERCIAL AGENTS AND OTHER REPRESENTATIVES}

In the following schedule all sorts of commercial agents and other representatives are listed and defined. The kind of agency that appllies is indicated:

(1) Agent and a named principal

(2) Agent and an unnamed principal

(3) Agent and an undisclosed principal

Broker:

Commission agent:

Commission merchant:

Commissionair:

Del credere agent:

Delivery agent:
Agent whose ordinary course of business is to negotiate and make contracts for the sale and purchase of goods and other property of which he is not entrusted with the possession or control ( 1 or 2 ).

Typical common law agent which refers to a large group of agents varying from estate agents to, for example, the forwarding agent. In general, the agent does not incur liability, he drops out of the transaction; so the principal is liable under the contract (1).

A UK type of commission agent who contracts in his own name and whose principal is not liable (1).

A typical civil law agent who concludes a contract in his own name, who is personally liable and entitled under the main contract and who does not bind and entitle his principal ${ }^{61}(3)$.

Agent who, in consideration of extra remuneration, called a del credere commission, guarantees to his principal that third parties with whom he enters into contracts on behalf of the principal will duly pay any sums due under those contracts ${ }^{62}(1)$.

Agent who maintains a stock of goods from which he regularly fills orders (1).

61 H.L.E. Verhagen, Agency in Private Iniernational Law, p. 36.

62 Factorlbroker/del credere agents from F.M.B. Reynolds, Bowstead on Agency, op cit., n. I, p. 23. 
Distributor:

Estate agent:

Factor:

Forwarding agent:

Independent contractor:

Mercantile agent:
Independent merchant who purchases from the manufactures or other suppliers and resells; the distributor deals on his own account; that is, his purchases are made in his own name and on his own credit and he bears the credit and risks incidental to his sales; a distributor, as such, is not an agent of the manufacturer or supplier ${ }^{63,64}$.

Agent who is employed to find a purchaser for property, has implied authority to make representations or to give warranties relating to the property; however, he has no authority to effect an actual contract for the sale of property unless explicitly authorised so to do ${ }^{65}(1$ or 2$)$.

Agent whose ordinary course of business is to sell or dispose of goods, of which his principal has entrusted him with the possession or control; the factor was a trading person who was well known and widespread in the nineteenth century (Factors Act 1899); nowadays a factor is called a mercantile agent (1).

An agent who ships or transports goods; the trade has a custom that a forwarding agent incurs personal liability for freight charges whether they are transported by sea or air; the result is that after paying the transportation costs he can recover this payment from his principal ${ }^{66}(1)$.

A person who contracts with another to do something for him but who is not controlled by the other nor subject to the other's right to control with respect to his physical conduct in the performance of the undertaking; he may or may not be an agent; examples of the independent contractor type of agent include brokers, factors, attorneys at law, anctioneers, selling agencies and collection agencies ${ }^{67}(2$ or 3$)$.

Agent who has in the course of his ordinary activities the authority to sell the goods which he has in his possession (as well as the power to purchase goods) ${ }^{68}$ (10).

63 P.H. Vishny, Guide to International Commerce Law, (Shepard"s/MoGraw-Hill, Colorado Springs, 19811$),$ p. $4-4$.

64 The distributor is not an agent at all, he is an independent dealer who, legally speaking, only represents himself.

65 A.G. Guest, Awsion's Law of Contract, 26th ed. (Clarendon, Oxford, 1984), p. 542.

66 Halsbury's Laws of England, 4th ed. (Butterworths, London, 1990), p. 11 .

67 H.G. Reuschlein \& W.A. Gregory, Handbook on the Law of Agency and Partnership, p. 4.

68 R. Baldi, Distributorship, Franchising, Agency, (Kluwer, Deventer, 1987), p. 111. 
Receiver:

A person appointed to carry on or superintend a trade, business or undertaking in addition to receiving rents and profits, or to enter outstanding property; he bas the power to deal with the property and to appropriate the proceeds in a proper manner (1).

\section{7}

\section{SUMMARY}

According to common law, an agent binds his principal when he acts as an agent. Even when the agent does not disclose that he is acting as an agent, evidence may subsequently be cited to show that the undisclosed principal was the real principal in the transaction and he may sue or be sued on the contract concluded by his agent. If the third party knows the existence of a principal but does not know his actual name, the principal is liable as if his name is known.

According to civil law, the principal is bound by the contract concluded by his agent only if, the agent acted in the name of his principal. This is called direct representation. If the agent acted in his own name, the principal is not bound by the contract. Civil law does not define this latter situation (indirect representation) as a kind of representation. The acting person does not pretend to act on behalf of someone else but implies that he intends to legally bind himself to the third party.

A broker according to common law is an intermediary whose ordinary course of business is to negotiate and make contracts for the sale and purchase of goods and other property, of which he is not entrusted with the possession, ownership or control. He is not a party to the contract, and he is therefore, from a legal point of view, not an agent but an intermediary. A civil law broker, generally speaking, does not have the authority to conclude contracts in the name of a principal. This principal can, however, give the broker the authority through a power of attorney (vollmacht according to German law). It is generally accepted that the broker is an intermediary who is independent, meaning he works for any number of clients.

The common law term commission agent is a generic term which includes a wide range of different types of agents. An English commission agent can be either an estate agent, forwarding agent or commission merchant. A US commission agent is a independent contractor which is also a generic term for agents such as a broker, selling agent or attorney. So, if the term commission agent is used, it can only refer to a common law agent, which can then include 
different kinds of agents. Commission agent in a civil law context is usually translated as commissionair. A commissionair, however, is a typical civil law concept with its own typical civil law meaning and application.

A commissionair acts on behalf of his principal but concludes contracts in his own name. The principal is in this case not bound by the contract which the commissionair concludes with the third party. The commissionair is solely liable under the contract with the third party. The principal is only bound by the commission agreement concluded between the principal and the commissionair.

In the author"s view, the commissionair has one element which can be found in common law agency rules, namely that a commissionair has an unnamed principal. The third party who, for example, buys something from a commissionair knows that the commissionair acts on behalf of a seller but does not know the actual name. So, in this sense, the commissionair could be compared to the unnamed principal. The legal consequences are nevertheless completely different; the commissionair does not create liability for his principal under civil law, whereas the agent who has an unnamed principal from a common law perspective does create liability for his principal. 


\section{The German Agency Permanent Establishment}

The history of agencies and permanent representatives goes back to the end of the last century. The problem of clouble taxation forced the late Prussian municipalities to take measures which would result in avoiding this double taxation. The PE was the first step in this development. As Skaar shows in his study, the term PE was originally not used as a tax concept but occurred as early as 1845 in the Industrial Code of Prussia for other purposes.

The first German expression for PE as a tax concept was stehendes Gewerbe (fixed business place). Skaar described the development from stehendes Gewerbe to Betriebstatte (PE) in detail but, interestingly for this study, until the first codification of the PE concept in Prussia ${ }^{2}$, PE was used alongside terms such as agency, place of management, branch and place for the sale of goods. ${ }^{3}$

A fixed physical location formed the core of the PE concept in those days. Another important element was the foreigner's intention to perform business activities from this domestic location. Permission had to be obtained from the authorities for a foreigner to conduct business in Prussia. ${ }^{4}$

\section{2}

\section{THE FIRST APPEARANCE OF THE AGENCY PE}

The first appearance of the Agency PE as a tax concept (ständige Vertreter in German) was in the double taxation convention on 21 June 1899 between Prussia and Austria/Hungary. In that convention the ständige Vertreter was mentioned as a person conducting domestic business for the foreign principal.

1 Cr. A.A. Skaar, page 72.

$2 \$ 2$ Abs. 1(b) Einkommenstenergesetz, June 24, 1891, Preußische Gesetzessamming 175 (1891).

32 Abs. 1 of Kommunalabgaben-Notgesetz. The Kommunalabgaben-Notgesetz was special legislation concerning municipal taxes.

4 Cf. \& 18 Allgemeine Gewerbeordnung January 17, 1845, Gesetzsammlung für die Königlichen PreuBischen Staaten (5). 
Acting in the name of the principal or on behalf of the principal was not explicitly mentioned at that time. These were later recognised as two core elements of the Agency PE concept.

The second sentence of article 2 of this treaty stated:

"Permanent establishments are branches, factories, wharehouses, offices, purchasing or sales offices and other places of business for carrying on the business of the entrepreneur himself, partner, deputy manager or other permanent representative." [See Appendix, Quote 3 for original in German.]

The object (the PE) in this definition is the first and prominent condition of the PE concept. First, there must be a physical location and, second, a person de facto conducting the business in this physical location. This person can be the entrepreneur himself (Unternehmer), his partner (Geschäftsteilhaber), deputy manager ${ }^{6}$ (Procuristen) or any other permanent agent (Ständige Vertreter). In other words, as long as a PE is present, it is irrelevant who is responsible for the actual conduct of the business of the entrepreneur.

The text of the provision demonstrates this in the sentence: "zur Ausübung des stehenden Gewerbes". This concept will be defined for the purposes of this study as the replacement theory. An entrepreneur can conduct his business himself but can, if he wishes, be replaced by his agent. If the agent has the same competence or power as the entrepreneur, there is actually no difference between the entrepreneur and the agent regarding the actual management or business organisation. It is, however, essential that the agent has the same powers as the entrepreneur himself. Early German legislation supports this view. Paragraph 61 of the General Business Licence Law (Allgemeine Gewerbeordnung), dated 17 January 1845 , states with regards to the power of the deputy or agent:

"The authority regarding the company can be exercised by the representative; it must not only be sufficient regarding the independent

5 C. Parry (Ed.), Consolidated Treaty Series, vol. 187. (Oceana Publications Inc., Dobbs Ferry, New York), p. 360. The original text of the treaty is quoted from this source. [1898-1899]

6 Deputy manager, meaning a confidential clerk or attorney who has been granted a power of attorney. 
company in general, but also regarding specific conditions of the respective company." ? [See Appendix, Quote 4 for original in German.]

This law stipulates that the agent must not only have a general power to conduct business but must also meet the specific requirements or conditions concerning the actual business he conducts. An agent could, in this sense, only obtain a business licence if he had full power to conduct the business. The only difference between the agent and the entrepreneur is that the latter owns the business. If an entrepreneur from abroad conducts business, a state has a right to levy taxes when this business has sufficient local substance to meet the general PE conditions. When not the entrepreneur himself but a fully authorised agent actually conducts the domestic business, there is no reason for the domestic state not to apply the same rules concerning taxation of the domestic business; otherwise, it would be easy to avoid a taxable presence by having the entrepreneur being replaced by his agent. As is the case in determining a permanent establishment, the factual assessment is decisive. If the facts show that there is no difference between the entrepreneur or his agent conducting the business, classifying the agent as a permanent establishment can be expedient. The author believes that the replacement theory is the prime element of the Agency PE concept. The agent as a PE was created because an agent can conduct business to the same extent as the entrepreneur himself. This concept can be recognised in the current OECD definition of the Agency PE where the agent acts on behalf of an enterprise and with the authority to conclude contracts in the name of the enterprise. In both cases the agent is acting as the entrepreneur's replacement.

\section{3}

THE DEVELOPMENT OF THE CONCEPT OF THE PERMANENT AGENT

The Industrial Revolution caused mass production and enlarged the distances between manufacturers and consumers. Because of this increase in production and at the same time because the marketing and selling areas grew, the entrepreneur could not conduct his business alone. This is why the concept of the commercial agent appeared in Germany at the end of the last century. The

7 Allgemeine Gewerbeordnung vom 17. Januar 1845, nr. 2541, Gesetz. Sammlung für die königlichen Preußischen Staaten, paragraph 61 , page 53. 
German Commercial Code (Handelsgesetzbuch) of 1897 is the first known law which describes the rights and obligations of the commercial agent. ${ }^{8}$

At that time, a group of people who acted as aids to trade were active in the trade business. They represented several foreign principals in the area where they were settled. These trade aids had barely any authority to act on behalf of the foreign principal. The foreign principal's approval was essential for the legal validity of a sales agreement concluded by the trade aid. During that same period, the travelling salesman, however, did have sufficient authority to conclude contracts binding the foreign principal. All these travelling salesmen were employed by their principal. A customer of a travelling salesman always knew that he conducted business with a company employee. Most of the trade aids had several principals whose presence or identity could be unknown in an early stage of the negotiating process. Because of the essential approval of the principal with regard to any agreement concluded by the trade aid, the presence of the principal was always disclosed before the agreement was final. ${ }^{9}$

Because of these developments in the early German trade business, the tax concept of the agency was born after the general legal concept was created. Because of the variety of agents, German municipalities had to find a way to create tax liability for the foreign principals of all these agents. At that time it was agreed that a company could not only be represented by one of its employees (which used to be the general idea, as the concept of the travelling salesmen demonstrates) but also by a domestic merchant who simultaneously acted for the foreign principal. The domestic merchant could have his own trading company but also act on behalf of a foreign principal. In the latter case, tax liability occurred for the foreign principal. ${ }^{10}$ After this development, a provision concerning the Agency PE was included in the German bilateral tax treaties. In 1922, a provision concerning the Agency PE was included in the German national tax laws. Although the interaction between legislation and case law was close, it seems clear that case law was the leading force in the development of the agency as a PE. ${ }^{.1}$

8 H.H. Lidgard, C.D. Rohwer, \& D. Campbell, A Sumey of Commercial Agency, (Kluwer Law and Taxation Publishers, Deventer 1984), p. 60.

9 Cf. R. Baldi in Distributorship, Franchising, Agency - Community and National Laws and Practice in the EEC, (Kluwer Law and Taxation Publishers, Dewenter 1987), p. 8.

10 Cf. O. Bühler, Einzelsteuerrecht, Verlag Franz Vahlen, Berlin 1938, page 138.

Il A.A. Skaar, op cit., n. 1, p. 471. 


\section{THE AGENCY PE IN EARLY GERMAN LEGISLATION AND CASE LAW}

\subsubsection{German Income Tax Act 1922}

Before 1922, German tax law only created a limited tax liability for a PE (Betriebsstätte). On 8 April 1922, however, the German Income Tax Act (Einkommensteuergesetz) extended the limited tax liability to foreign principals who acted through a domestic permanent agent. This provision was also applicable to the German Corporate Tax Act (Körperschaftsteuergesetz) through a connecting provision.

It was agreed that the general PE concept alone did not create tax liability for all the foreign parties' possible domestic activities. The permanent agent could not create tax liability for the foreign principal mainly because the entrepreneur lacked a permanent business centre. If, economically speaking, no significant differences could be detected with regard to a general PE, tax liability for the Agency PE was considered justified. It was noted:

"...in case of the permanent agent, despite the lack of a fixed establishment, the economic cirumstances are essentially the same as in the case of a permanent establishment, meaning, fundamental business functions as the concluding of contracts are performed inland."12 [See Appendix, Quote 5 for original in German.]

In other words, the activities of the agent (ständige Vertreter) result in the same economical circumstances as the PE, even though a fixed business place of the entrepreneur is absent. The concluding of contracts is considered to be a decisive ellement of the business activities of the agent, when comparing the economic circumstances of the agent with the PE.

Whether such a representative is an employee or not was considered to be of no relevance. In that sense, equality was achieved between a foreigner acting through a German based $\mathrm{PE}$ and a foreign principal acting through a person who does business in Germany on behalf of the principal. ${ }^{13}$

In the 1925 text of the new provision in the German Income Tax Act (article 3, paragraph 2, point 2), the limited tax liability also included:

12 BT Drucks. 1921 , Nr. 2867, page 5, published as well in BStB1. II 1972 , page 788.

13 Cf. A.H.M. Daniels in his annotation concerning Court The Hague, June 25, 1986, ar. 576/84, FED $1987 / 297$. 
"Business income, where a permanent establishment is maintained inland or where a permanent agent is ordered." ${ }^{\text {14 }}$ [See Appendix, Quote 6 for original in German.]

Business income for which a domestic PE is maintained or a permanent agent is appointed is regarded as taxable domestic income. German tax law, however, did not define the concept stöndige Vertreter (Agency PE). Case law determined the definition of the Agency PE.

\subsubsection{German Case Law}

The first relevant case was ruled by the Reichsfinanzhof (RFH) on 4 March $1927 .^{15}$ A foreign company had a tobacco stock in a German bonded warehouse (Zollniederlage). The question was whether this stock of goods could be regarded as a PE. Interestingly, the storage took place in the name of the German forwarding agent. This forwarding agent was regarded as an Agency $\mathrm{PE}$ of the foreign company. The court held that the forwarding agent and an employee of the foreign company could have disposal of the warehouse. The PE activity (in this case, the storage of tobacco) had to be attributed to the activities of the foreign company and the entrepreneur or his permanent representative had to exercise these activities. The court described the ständige Vertreter (Agency PE) as follows:

"as a permanent agent, conducting the same business as the entrepreneur, meaning, is dependent on him and conducts business activities in stead of the entrepreneur." [See Appendix, Quote 7 for original in German.]

The Agency PE must be dependent (Abhängig) on his principal and act instead of his principal regarding activities concerning the principal's enterprise.

In Reichsfinanzhof. 28 June $1935,{ }^{16}$ the court explained what it meant by the term dependent or dependency relationship (Abhängigkeitsverhältnis). In this case, the question was whether the manager of a filling station could be regarded as an Agency PE. The foreign principal owned the filling station, and the fuel was sold in the name of the principal and on behalf of the principal. The

14. Einkonmenstenergesetz August 10, 1925, Reichsgesetzblatt Part 1, page 189.

15 RFH 4. März 1927, I B 1/27, Reichssteuerblatt 1927, Nr. 161.

16 RFH 28. Juni 1935, IV B 20/34, Reichssteuerblatt 1935, Nr. 727. 
principal determined the selling price of the fuel. The manager received a commission. The RFH, in this instance, regarded the manager as an Agency PE of the principal. The court used the same definition of the Agency PE as was used by the Reichsfinanzhof on 4 March 1927. On the dependency relationship of the agent versus his principal, it stated:

"This dependency is not the social dependency, which also exists in employment relationships, but the commitment to business instructions of the principal. It can also be present without an employment relationship or other legal basis present." [See Appendix, Quote 8 for original in German.]

Just as an employee is, without any doubt, regarded as being dependent on his employer, the court stated that non-employees can also have a kind of dependency relationship with a principal. The court considered this dependency to be present if the principal's business instructions bind the agent. ${ }^{17}$ In the continuation of this court decision, in Reichsfinanzhof, 11 September $1935,{ }^{18}$ the court also stated that the fact that the manager of the filling station had a certain freedom of movement did not stand in the way of their decision to regard him as dependent. The manager had the right to be replaced by someone else and receive commission instead of wages. These facts, according to RFH, disagreed with the assessment of the manager as an employee but not with the assessment of the manager as an Agency PE (ständige Vertreter).

Reichsfinanzhof, 22 March $1934,{ }^{19}$ dealt with almost the same proposition as RFH, 4 March 1927, involving a stock of goods or warehouse in Germany belonging to a foreign entrepreneur. The follow-up that RFH gave to its description of the Agency PE is interesting:

"As such a body (referring to the Agency PE, $A P l$.), also an independent entrepreneur, like for example an agent or haulage contractor, can be engaged, insofar his business activities are out of the

17 In this context $\mathbb{1}$ consistently use the terms agent and principal to point out the factual relationship. These terms, however, are in some cases legally not correct. Terms like "client" or "customer" are sometimes more appropriate than principal; clatity forces me, however, to use the term "principal". Especially in this case law discourse, its clearer and more comprehensible to consistenly use the terms agent and principal.

18 RFH 11. September 1935, IV B 11/35, Reichssteuerblatt 1935, Nr. 947.

19 RFH 22. Mărz 1934, IV B 47/33, Reichssteuerblatt 1934, Nr. 443. 
ordinary course of his business" [See Appendix, Quote 9 for original in German.]

The Reichsfinanzhof opens up the possibility that the agent, as an independent entrepreneur, can indeed constitute an Agency PE because of the activities he conducts on behalf of his principal. If these activities are not similar to the core activities of his own enterprise, the agent (independent entrepreneur) acts as a real agent or representative (Organ) of the foreign enterprise.

In Reichsfinanzhof, 13 September $1929,{ }^{20}$ a case was decided concerning the insurance business. An English insurance company (principal) had an agreement with a German insurance company (agent) to re-insure 50 percent of the German insurance policies. When clients preferred English policies instead of German ones, the business threatened to wander abroad. The German company then suggested that the English company authorised it to conclude insurance policies in the name of the English company, therefore generating more business. The principal agreed, since they re-insured 50 percent of all the policies issued by the agent, and authorised the manager of the German insurance company accordingly.

The German tax authorities considered the German manager to be a ständige Vertreter (Agency PE) of the English principal. The principal argued that the manager was to be regarded as completely independent and that they had no economic interest in the insurance policies concluded by their agent, even if these contracts were concluded in their own name.

The German RFH did not agree with these two positions. They reasoned that the German manager was justly being regarded as an agent because he had the authority to act in the name of the principal. He should be regarded as a permanent agent, because the authorisation was given without any time limit. Economically, the agent acted as a Zweigniederlassung (branch) or Prokuristen (deputy manager) of the principal, according to the court. Finally, the principal would certainly have an interest in the number of policies issued by their agent since they would participate in each contract through their 50 percent reinsurance.

It was decided in this case that the ständige Vertreter, who creates tax liability for the foreign company he represents, could be a dependent employee but also

20 RFH 12. September 1929 , I A a 263/29, Sammlung der Entscheidungen und Gutachten des Reichsfinanzhofs, Bd. 25, 1929, Nr. 97. 
an authorised independent businessman. If the independent entrepreneur or businessman had full power of attorney, he would be regarded as a permanent agent of the company he represented.

In Reichsfinanzhof, 23 July $1930,{ }^{21}$ a Dutch firm had a kind of pooling arrangement ${ }^{22}$ with a German firm concerning the mutual purchasing and selling of raw tobacco. The German tax authorities claimed that the German firm acted as an Agency PE of the Dutch firm. The court disagreed with the tax authorities' standpoint on the following grounds:

"The German company is not obliged, even not entitled, without prior notification to purchase on the joined account. That's why in case of purchasing it acts as an agent, but not as a permanent agent (Agency PE, APl.) of the Dutch company" [See Appendix, Quote 10 for original in German.]

From this it follows, in the author's view, that the court held that the German firm had no authority to conduct business on behalf of the Dutch firm; the Dutch firm had to confirm and approve every transaction. Furthermore, the court stipulated that no limited tax liability (through a PE or Agency PE) should arise for Metaverbindungen (pooling arrangements) if either contracting parties had no obligation to participate in single business transactions undertaken by the other party.

The court pointed out that a pooling arrangement did not mean that both contracting parties would constitute one company or that both parties participated in each others' businesses. RFH formulated the essence of a pooling arrangement as follows:

"What exists are only contractual relations between both firms, leading to claims from one against the other." [See Appendix, Quote 11 for original in German.]

A pooling arrangement is a mere contractual relationship resulting in mutual contractual claims. The court agreed with the Minister of Finance's proposition that it is possible in a pooling arrangement for one party to constitute an Agency

21 RFH 23. Juli 1930, VI A 2120/29, Reichssteuerblatt 1930, Nr. 913.

22 The case names this agreement a Metaverbindung, meaning a legal relationship were both contracting parties are conducting business in their own name, but for their mutual benefit. 
PE of the other foreign pooling partner. The court described the circumstances which could lead to an Agency PE in a pooling situation:

"In particular a business relationship of a longer period and continuity must exist, where the business is conducted, because of an existing contractual relationship, not on the basis of special agreements for a particular business deal." [See Appendix, Quote 12 for original in German.]

The business connection or relationship must have a certain permanency and continuity. If business deals are concluded, they must be based on that regular business relationship instead of special agreements for a particular business deal. In this case, a permanent and lasting arrangement was indeed present; however, every purchasing transaction was concluded on the basis of specific one-off agreements.

In the Reichsfinanzhof rwling on 29 June $1934,{ }^{23}$ the court decided that the occasional presence of travelling salesmen from a foreign company in Germany did not constitute an Agency PE even if those salesmen represented the general interests of the foreign enterprise.

The equal treatment of the Agency PE as a PE was only appropriate when the agent had a fixed business place in Germany. The German Supreme Tax Court stated:

"The resemblance with a permanent establishment is only present, if the foreign company has a fixed place of business through which the agency is conducted. It is not obliged that a permanent agent should be one and the same person, it's even not obliged that the agent lives inland."[See Appendix, Quote 13 for original in German.]

So, the ständige Vertreter did not always have to be the same person, or have to actually live in Germany. However, a fixed place of business should exist from which the agent conducts the activities for the principal. The court determined that the occasional sending out of travelling salesmen by a foreign company into Germany did not constitute an Agency PE. The fact that these salesmen represented the interests of the foreign company in Germany was not sufficient 
for the finding of an Agency PE. The lack of permanency of the representation in this case proved to be decisive.

The RFH explains the term dauernde Einrichtung ${ }^{24}$ in relation to the agency concept:

"..., there must be a fixed place of business, which has, economically, the same function as a permanent establishment." [See Appendix, Quote 14 for original in German.]

RFH points to the German Income Tax Act of 1922 ( $\$ 4.1$ of this chapter). This act introduced the Agency PE provision because the foreign principal involved with an Agency PE did not have a local installation or establishment at his disposal, according to the court. In this instance, the term danernde Einrichtung refers to the PE. If the agent had some kind of physical permanent presence in Germany, like for example an office, this office was considered to be a dauernde Einrichtung of the foreign principal.

\section{5}

THE 1932 LEAGUE OF NATIONS GERMAN REPORT

Further details on the Agency PE concept can be deducted from the rules concerning the limited tax liability. In the 1932 League of Nations German report ${ }^{25}$, the limited tax liability (beschränkte Steuerpflicht) was discussed extensively. The draughtsmen of the German report applied the rules for the German limited tax liability to:
a) a $P E$;
b) an agent selling out of a stock owned by the foreign enterprise;
c) an agent with power of attorney;
d) a commission agent or broker, and
e) a travelling salesman.

The report states that the rules applicable to the taxation of income from the carrying out of a trade or a business through the five cases mentioned above "may be set forth as follows...". This indicates, in my view, the hypothetical

24 Dawende Einrichnong can, in my view, only be justly translated into "permanent establishment".

25 Taxation of Foreign and National Enterprises, the German report, LON, Geneva 1932, page 114. 
content of their analysis. The report, however, contains interesting and certainly relevant material for this study. The text of the analysis is given below:

"In cases (1) and (2), the liability to German taxation arises because a permanent establishment (Betriebsstätte) is maintained in Germany.

In case (3) permanent establishment in Germany can also be assumed if there is a plant used by the authorised agent for carrying on a trade. If this is not so in this case, and in cases 4 and 5 , there will be no liability to tax, on the grounds of there being a permanent establishment in Germany; but it remains to be examined to what extent liability to tax is incurred by having a permanent agent (ständige Vertreter) in Germany. An agent is a person who carries out a legal transaction for another person and in his stead, and it is irrelevant with regard to third parties whether he acts in his own name or in the name of his principal. The term "permanent agent" includes an independent businessman, for instance, a general agent (Generalagent), or other agent, commission agent (Kommissionär), forwarding agent (Spediteur), or a representative who, it is true, is dependent, but regularly resides in Germany, such as a managing clerk (Prokurist), an agent with full power of attomey (Handelsbevollmächtiger) or other employees, or a travelling salesman. A non-recurring representation, or one which only lasts for a short time, does not, however, give rise to tax liability for the foreign enterprise. For example, the transaction of a broker (Makler) within the meaning of the German law is not sufficient to give rise to taxation, because it is the essence of his business to undertake the handling of definite transactions for gain on behalf of another without being permanently employed by this other party on a contractual basis. Having regard to these remarks, it would seem that, in case $(1)^{26}$, the agent who receives a commission must in principle be regarded as a permanent agent, but not the broker, within the meaning of the German Commercial Code. As for the travelling salesman, it would depend upon the circumstances of the case, which may be constantly differing. Where there is an agent with a power of

26 The original text refers to case 1 . According to the previous argument it seems not logical that the dratghtmen referred to the case 1 at the top of the analysis, namely the PE. I think they meant the "commission agent" when referring to case 1 . 
attomey, however, the existence of a permanent agent must be assumed., 27

It is concluded from this analysis that the presence of a fixed locall plant or installation is sufficient to constitute a PE. In cases (1) and (2), a place owned by the entrepreneur is present where the entrepreneur or representative can carry on the business himself, so a PE exists in both instances. In the author's view, this line of reasoning proves the function of the Agency PE provision as an addition to the existing PE concept. Checking the Agency PE provision is only expedient if the general PE conditions are not met, although German case law offers no real proof for this assumption.

The replacement theory (paragraph 2 of this chapter) is confirmed by the definition of the agent as: "a person who carries out a legal transaction for another person and in his stead."

This line clearly states "and in his stead", not "or in his stead". The agent replaces the principal and because of this the definition above continues with: "and it is irrelevant with regard to third parties whether he acts in his own name or in the name of the principal."

It seems an illogical statement that it is irrelevant whether the agent acts in his own name or in the name of his principal. Civil law tradition makes a distinction between the agent acting in his own name and the agent acting in the name of the principal. Germany, as a typical civil law country, defines the relationship where the agent acts in the name of his principal as a type of direct representation (offene Stellvertretung), meaning that the agent binds his principal as a result of this type of legal representation. ${ }^{28}$ Lex loci solutionis ${ }^{29}$ confirms the applicability of German law when the agent concludes contracts in Germany. When the agent acts in his own name, generally speaking, the principal is not liable concerming the customer.

27 Taxation of Foreign and National Enterprises, a study of the tax systems and the methods of allocation of the profits of enterprises operating in more than one country, the German report, League of Nations Geneva 1932, page 115.

28 M. Wurm, Prokura und Handlungsvolmacht - Handelsvertreter und Makler, Kolin 1988, page 4.

29 The law of the place where a contract is to be performed or a debt is to be paid; L. Strikwerda, Inleiding tot het Nederlands Internationaal Privatrecht (Introduction to Dutch Private International Law), Groningen 1995, page 183. 
According to Bellstedt, this problem relates to one of the conditions of the limited tax liability of article 49 of the German Income Tax Act. The agent must, according to German domestic tax law, act instead of the principal and be bound by his instructions. As long as the agent meets these two requirements, it is indeed irrelevant whether or not he acts in his own name or in the name of his principal. ${ }^{30}$

According to German commercial law, the Makler (broker) concludes contracts on behalf of, and in the name of, the principal. Because of the absence of a long-term relationship between a Makler and a principal, the Makler is not considered to be a permanent representative (no Agency PE). A one-off deal concluded by the Makler, or for that matter any other representative, is not based on a sufficient permanent relationship, and lacks enough duration or permanence, to conclude that the Makler is acting instead of the principal and thus replacing the principal. The ständige Vertreter, or Agency PE, has to be active for the foreign principal during a certain period of time (eine gewissen Dauer). The German expression ständige means "permanent" or "continuous" in English.

\section{THE AGENCY PE IN GERMAN DOUBLE TAXATION CONVENTIONS}

The 1932 League of Nations report continues with the Agency PE according to double taxation conventions concluded by Germany at that time:

"In the double-taxation treaties which have hitherto been concluded by the German Reich, It is expressly stated that the term 'permanent establishment' does not include the maintenance of business relationships merely through a completely independent agent, or the maintenance of a representative (agent), who, although he is constantly employed on behalf of individuals or corporations of one State in the territory of the other State, merely acts as intermediary in effecting business transactions without being empowered to conclude the transactions on behalf of the firm which he represents. In accordance with

30 Ch. Bellstedt, Der "ständige Vertreter" im Außensteuerrecht, Der Betrieb 1968, Nr. 38, page 1554: Also K. Kunze, Der Begriff der Betriebsstätte und des ständigen Vertreters, Mannheim 1963, page 73 . 
these provisions, the facts in the cases (3), (4) and (5) might be such that the liability to tax within Germany would not arise."31

German treaty policy excluded the completely independent agent from the Agency PE concept and the agent who only acts as an intermediary and has no authority to conclude contracts. ${ }^{32}$ This can be found, for example, in the 1935 double taxation convention between Germany and Finland. The Final Protocol reads:

"It is agreed that the maintenance of business relations exclusively by means of a completely independent representative shall not constitute a business establishment (Betriebsstätte) in the sense of Article 3. The same shall apply in regard to the maintenance of a representative (agent) who, whilst permanently acting for individuals or companies of the one State in the territory of the other State, only negotiates business, without having full power to conclude transactions on behalf of the firm he represents.

Almost the same text can be found in the double taxation conventions between Germany and Romania (8 February 1937), Germany and Belgium (1 December 1938 ) and Germany and Denmark (16 December 1938). ${ }^{34}$ The first treaty with this concept was the treaty with Sweden, dated 25 April 1928.

Treaties concluded before 1928 did not contain the clause mentioned above regarding independent agents. In those treaties, a standard provision regarding the Agency PE was included. An example of this can be found in the 1921 treaty between Germany and Czechoslovakia. Article 3 reads:

"The term business establishment shall include: branch establishments, factories, offices where purchases or sales are effected, depots, counting-houses, and all other business establishments maintained

31 See sipra note 101.

32 Bühring, Das Betriebsstättenprinzip in den deutschen Doppelbesteuerungsabkonmen, Der Betriebs-Berater, Vol. 18, June 30, 1954, page 558.

33 Agreement for the avoidance of double taxation in the matter of direct taxes between Finland and Germany, Helsinki, September 25, 1935, Treaty Series, Volume CLXXI, No. 4000, translated by the Secretariat of the League of Nations.

34 The treaty texts can be found in Diamond \& Diamond's Internationa! Tax Treaties of all Nations, Volume 1, New York 1975. 
for the purpose of carrying on the said industry, either by the owner himself, his partners, managers or any other permanent representatives." 355

German Double Taxation Conventions concluded after 1945 did not include the term ständiger Vertreter ${ }^{36}$; conventions concluded after 1958 were very much influenced by the OEEC recommendations. The older treaties were largelly determined by article 16, paragraph 2, under 2, of the Steueranpassungsgesetz (StAnpG). ${ }^{37}$ The Steneranpassungsgesetz was a general fiscal law which gave an Agency PE definition for all German tax laws. German Double Taxation Conventions used their own definition. ${ }^{38}$

In the definition of a PE in article 16, paragraph 2, under 2, of the Tax Revision Law (Steueranpassungsgesetz), is, amongst others, the Agency PE (ständigen Vertreter) listed. This German domestic provision is obviously a pre-war definition of the Agency PE. The Steuerampassungsgesetz was enacted on 16 October 1934. All the old treaties are based upon this PE concept. This provision created the term Vertreterbetriebsstätte or, in English, the Agency $\mathrm{PE}{ }^{39}$ The Agency $\mathrm{PE}$ concept, according to the Steueranpassungsgesetz, is treated as an example of a PE.

In article 49 of the German Income Tax Act (Einkommensteuergesetz) the Agency $\mathrm{PE}$ is mentioned next to the $\mathrm{PE}$, in that sense regarded of equal value. ${ }^{40}$ According to article 16 StAnpG, a PE is present if the entrepreneur or his agent operates through a local establishment. This means that the entrepreneur can be replaced by his agent without altering the PE status. ${ }^{41}$

35 Double taxation convention between Germany and Czechoslovakia, Prague, December 31 , 1921, Treaty Series, Volume XVII, No. 447.

36 These treaties followed the League of Nations London/Mexico Model APE provision.

37 CF.K. Kunze, Dar Begriff der Betriebsstätte und des ständigen Vertreters, Mamnheim 1963, page 71 .

$38 \mathrm{Cl}$. H. Flick, German report on the development in different countries of the concept of a permanent establishment, Studies on International Fiscal Law, Cahiers de droit Fiscal International, Volume L II, Stockholm 1967, page 444.

39 According to H. Gebbers, Der standige Vertreter bei Grundstückvermietung oder verpachtung, Die steuerliche Betriebsprufung 4/89, page 78.

$40 \mathrm{Cf}$. Klaus Kunze, Der Begriff der Betreibsstătte und des ständigen Vertreters, page 72.

41 Bend Münch, Der doppeldeutige Begriff des "ständigen Vertreters" im geltenden deutschen Aubensteuerrecht, Außenwirtschaftscienst des Betriebs-Beraters, März 1964, Heft 3, page 78. 


\subsubsection{Introduction}

In 1977 , the Steueranpassungsgesetz was replaced by a completely new general fiscal law called the Abgabenordnung (AO). Whereas the Agency PE was considered to be a type of PE in the Steueranpassungsgesetz, in article 13 of the $\mathrm{AO}$, the Agency $\mathrm{PE}$ concept was defined separately from the PE concept of article 12 of the $\mathrm{AO} .^{42}$

The conditions for an Agency PE were substantially altered. It is important in this respect that the present agency clause does not require the agent to have a right to use a fixed place of business. ${ }^{43}$ If the conditions of article 13 of the AO are met, limited tax liability is established on the basis of article 49 of the Einkommensteuergesetz (EStG), the German Income Tax Act. The EStG uses the PE and Agency PE concepts as two equal concepts; limited tax liability exists for income derived from a Gewerbebetrieb, meaning a trade or business, exploited through a PE or Agency PE.

The Agency PE concept of article 13 of the AO entails three important aspects. An Agency PE is a (legal) person who:

a) conducts business for an enterprise (Geschäfte eines Unternehmens besorgt);

b) acts durably and permanently (dies nachhaltig iut), and

c) must comply with the instructions of the principal (dabei den Sachweisungen des Unternehmens unterliegt). ${ }^{44}$

Individuals or corporations (or any other legal entity) can be an Agency PE. They can be employees, independent entrepreneurs or subsidiaries, according to some authors. ${ }^{45}$ The German tax authorities, however, issued a ministerial order in $1997^{46}$ where they explicitly stated that the Agency PE could not be established solely by an employee. An Agency PE must be established by a person who acts "instead of the entrepreneur himself. A statement which can be

42 H. Gebbers, see supra note 112, page 79.

43 A.A. Skaar, Permanent Establishment, page 472.

44 W. Kumpf, Betriebsstätte: Prinzip und Definition, contribution to "Die beschränkte Steuerpflicht", W. Haarmann, Fonum der Internationalen Besteuerung, Band 2, Köln 1993, page 40 .

45 H. Schaumburg, Intrmationales Steuerrecht, Köln 1993, page 102.

46 Bundesminister der Finanzen, Verwaltungsgrundsätze fur die Prufung der Aufteilung der Einkünfte und des Vermögens der Betriebsstätten international tătiger Untemehmen. Verfügung $1 \mathbb{1} / 1997$. 
traced back to the original concept behind the Agency $\mathrm{PE}$, namely the replacement theory (cf. paragraph 3.2). The new Agency PE definition does not require, contrary to the $\mathrm{PE}$ concept, a fixed location in Germany. ${ }^{47}$

\subsubsection{Conducting Business for an Enterprise}

According to article 13 of the $\mathrm{AO}$, the ständige Vertreter is in particular an agent who conducts business for an enterprise by concluding contracts (Verträge abschließst) or soliciting or negotiating contracts (vermittelt oder Verträge einholt). Article 13 of the $\mathrm{AO}$, under part 2, also includes the delivery agent. The delivery agent is an agent who maintains a stock of goods from which he regularly fills orders.

In the Bundesfinanzhof decision of 18 December $1990^{48}$, the court did not approve of a German independent sales representative being his own Agency $\mathrm{PE}$ in the former East German Republic (DDR). The independent sales representative was a resident of former West Germany and thus taxable on his worldwide income. He represented a German firm exclusively in former East Berlin and the rest of the DDR. The sales representative claimed to have an Agency PE in East Germany. His reasons were obvious: the former article 3 number 63 of the EStG stated that income derived from East German sources were not taxable in West Germany. ${ }^{49}$ The court stated that an agency relationship, based on the Agency PE concept, requires the agent to act instead of his principal within the framework of the latter company, thus implying two different persons.

Earlier German case law acknowledged the possibility that a domestic independent entrepreneur could be regarded as an Agency PE on behalf of a foreign principal. In BFH, 27 November 1963, a domestic independent purchasing agent (or importer) represented seven Spanish orange export firms. ${ }^{50}$ Interestingly, the court determined that the domestic agent had the power to conclude contracts in the name of his Spanish principal. It was decided that the independent entrepreneur acted outside the ordinary course of his business and therefore constituted an Agency PE, because an independent entrepreneur usually concludes contracts in his own name.

47 V. Kluge, Das deutsche Internationale Steuerrecht, Münehen 1992, page 172.

48 BFH 18. Dezember 1990 X R 82/89, Bundessteuerblatt 1991, Teil II, Nr.8, page 395.

49 Article 3, Nr.63, EStG states that tax-free are: Einküntte der in \& 49 bezeichneten Art, wenn sie in der Deutschen Demokratischen Republik oder in Berlin (Ost) bezogen worden sind;'. L. Schmidt, Einkommensteuergesetz, 6.Autlage, München 1987, page 40 .

50 BFH 27 November 1963 I $335 / 60$ U, Bundessteuerblatt 1964, Teil III, Nr. 5, p. 76. 
The agent who concludes contracts must have a Vollmacht (authority or power of attorney) to act instead of the principal. ${ }^{51}$ According to German civil law this would mean that the agent concludes contracts in the name of the principal. In the case of direct representation (offene Stellvertretung), the third party is aware that the agent does not conduct his own business but someone else's. German law therefore stipulates in article 164 of the Bürgerliches Gesetzbuch (German Civil Code) that the principal is liable if the agent shows his intentions (Willenserklärung), according to the will of the principal, by concluding a contract, not in his own name but in the name of the principal who is the one he represents. $^{52}$

This civil law view is not thought to be decisive when considering an Agency $\mathrm{PE}$. According to Schaumburg the actual economic presence is decisive, meaning that the agent acts instead and for the account of the principal. ${ }^{53}$

\subsubsection{Acting Durably and Permanently}

The time condition requires that the activities of the agent are not temporary. Jacobs finds that activities of an agent exceeding a period of 9 to 12 months, should not be considered to be of a temporary nature. Besides the actual duration of the agent's activities, Jacobs believes that the intent at the start of the agency relationship can be decisive as well. ${ }^{54}$ So, if the foreign company intends to establish an agency on a permanent basis, this time condition is fulfilled.

\subsubsection{Subjected to Business Instructions}

The final condition of article 13 of the $A O$ is that the agent must comply with the instructions of the principal. The German term for this condition is sachliche Weisungsgebundenheid. In the decision of the Bundestinanzhof of 28 June $1972^{55}$, a non-German limited company ran a shipping cargo service between America and Europe, whose main agency was based in the Netherlands. The ships also docked in Bremen and Hamburg. Two domestic shipbrokers represented the company in the German harbours. They solicited and negotiated freight orders, hauled in the freight and took care, in general, of the incoming

51 H. Gebbers, see supra note 112, p. 79.

52 M. Wurm, Prokura und Handlungsvollmacht - Handelsvertreter und Makler, Koln 1988, page 6.

53 H. Schaumburg, Internationales Steuerrecht, Köln 1993, page 102.

54 Cf. O.H. لacobs, see supra note 122.

55 Cf. BFH 28. Juni 1972, I R 35/70, Bundessteuerblatt, Teil II, Nr.24, page 785. 
ships and their cargo. They were bound by the instructions of the shipping company or the Dutch agent. The BHF ruled that the German shipbrokers were an Agency $\mathrm{PE}$ of the foreign company in question. This decision was contrary to previous case law, for example RFH 4 March 1927 and RFH 13 September 1929. In this particular case law, the independent agent was not considered to constitute an Agency PE. Before this ruling, a personal contingency ${ }^{56}$ relationship was essential for the Agency $\mathrm{PE}$. This contingency relationship implied that the agent submitted to the instructions of the foreign company.

An independent entrepreneur (for example, a shipbroker) was only considered to constitute an Agency PE if he, besides his own business activities, acted on behalf of a foreign enterprise. The agent's activities for the foreign enterprise had to fall outside the ordinary course of the agent's business. The court held that German commercial law should determine what the ordinary course of business could be. In the author's view, the contracting authority of the independent entrepreneur determines what falls within or without the ordinary course of its business. An independent entrepreneur who acts within the ordinary course of his business obviously concludes contracts in his own name. If he concluded contracts not in his own name, he would be acting on behalf of someone else's business.

In the 28 June $1972 \mathrm{BFH}$ ruling, the senate deviated from its previous line of reasoning. ${ }^{57}$ One of the arguments the senate put forward was that the Weisungsgebundenheid (compliance with the instructions or directions of the principal) did not require an actual personal contingency relationship. In an objective or businesslike contingency relationship, the business instructions of the principal would bind the agent. The senate reasoned that this last aspect was in fact decisive. An independent entrepreneur can also comply with the business instructions of the principal within the framework of his own business. So, in other words, the independent agent can also constitute an Agency PE if he is subjected to the business instructions or directions of his principal.

The term Sachweisungen of article 13 of the AO, although based on the case law mentioned above, does not confine its meaning strictly to the independent entrepreneur who acts as an agent on behalf of a foreign enterprise. Firstly, this condition is recorded in the general Agency PE definition of article 13 of the $\mathrm{AO}$, namely that an Agency $\mathrm{PE}$ is a person who conducts business for an

56 Contingent on the judicial meaning of the word, namely stressing the dependent character.

57 For example, BFH 27. Novernber $19631335 / 60$ U, Bundessteuerblatt 1964, Teil III, Nr. 5, p. 76. 
enterprise during a longer period of time, and is subjected to its business instructions.

Secondly, case law clearly shows the application of the condition of the Weisungsgebundenheid to all possible Agency PE cases. In, for example, the BFH ruling of 12 April $1978,{ }^{58}$ a US resident (former German resident) owned a German hotel which was leased to a German resident. In this case the senate regarded the lessee as an Agency PE of the US owner because the lessee acted according to the instructions of the lessor and, therefore, actually took care of the interests of the lessor. The lessor, for example, decided how much renovation (the actual amount in DM) could take place in a year, decided what actual renovations were to be undertaken and who should carry them out. The lessee stated that nothing happened without the explicit instructions of the lessor. The BFH confirmed its view that a lessee could be an Agency PE of the foreign lessor in BFH 28 July $1982 .{ }^{59}$

In a ruling of the BFH of 14 September $1994^{60}$, a German company (GmbH) sold industrial goods in the name of an English company who belonged to the same group of companies. The English company contested the view of a previous court (Finanzgericht) that the GmbH was an Agency PE of the English company. The BFH held that the GmbH should be considered an independent agent who acted within the ordinary course of his business. Because the GmbH was an independent legal entity, and carried out several different activities, the court held that the $\mathrm{GmbH}$, in this case, was sachlich and persönlich independent. The legal structure prevented, according to the court, the English company from enforcing the sachliche Weisungsgebundenheid. Another important element in this ruling is that the court explained the meaning of the condition in article 5, para. 6 of the OECD regarding the independent agent. The particular phrase that it defined was 'acting in the ordinary course of their business'. According to the BFH, 'ordinary course of their business' means that an agent must perform his usual activities, in other words, activities common in the day-to-day business. This interpretation would make it essential to look at the group of agents to which the agent in question belongs. The BFH points to the OECD Commentary where, in paragraph 38 , groups of agents are mentioned which refers to general commission agents who usually do not conclude contracts in the name of the principal.

58 BFH 12. April 1978 I R 136/77, Bundessteuerblatt 1978, Teil II, Nr.17, p. 494.

59 BFH 28. Juli 1982 I R 196/79, Bundessteuerblatt 1983, Teil II, Nr.3, p. 77.

60 BFH 14 September 1994, I R 116/93, Bundessteuerblatt 1995, Teil II, Nr, 6. 
German authors take the position that the sachliche Weisungsgebundenheid implies that the principal must actually and frequently intervene in the agent's activities on behalf of the principal. ${ }^{61}$ When the agent is actually conducting the principal's business, he must be submitted to the instructions of that same principal. The principal must have the power to actively intervene in this case. The factual circumstances are decisive. Furthermore, it is important that obedience to the wishes and demands of the principal are the primary concern of the agent when he conducts his business. ${ }^{62}$ Mössner points to the power of the principal. The principal can, if he desires, carry out his wishes. ${ }^{63}$

An independent agent, for example the commission agent, is likely to be considered an Agency PE on the basis of article 13 of the AO. The commission agent, too, is submitted to the business instructions of the principal. Because of this very reason, the German tax authorities introduced Section 222 of the Einkommensteuer-Richtlinien (Income Tax Act Guidelines). ${ }^{64}$ This income tax directive renounces German tax liability for the foreign principal who acts through a German broker or commission agent. There are, however, certain conditions attached to this provision.

\subsection{0}

\section{SECTION 222 INCOME TAX ACT GUIDELINES}

German double taxation conventions follow the OECD Model closely. On the basis of a German double taxation convention, the broker (Makler) and commission agent (Kommissionär) do not constitute an Agency PE on behalf of the principal because German DTCs contain a provision similar to article 5, paragraph 6, of the OECD Model. When, however the principal is resident in a non treaty country, tax liability in the previous case does exist on the basis of article 13 of the AO. To end this situation Section 222 of the Income Tax Act Regulations was introduced in 1993. ${ }^{65}$ The broker and commission agent will not constitute an Agency PE on behalf of a foreign enterprise even if the foreign enterprise is resident in a non-treaty state.

61 For exanple W. Kumpf, Besteuerung inländischer Betriebstätten won Steuerausländem, Köln 1982 , page 50.

62 M. Maßbaum/D. Meyer-Scharenberg/H. Perlet, Die Deutsche Unternehmensbesteuerung in europäischen Binnenmarkt, 1994, page 43.

63 J.M. Mössner and others, Stenerrecht international tätiger Unternehmen, Köln 1992, page 90.

64 H. Schaumburg, Internationales Steuerrecht, Köln 1993, page 103.

65 K-H Baranowski, Praktiker-Handbuch 1994 Außensteuerrecht, 18. Auflage, Düsseldorf 1994, page 1131 
The German commercial agent is an independent entrepreneur who, according to article 84 of the German Commercial Code, either negotiates business transactions or concludes contracts in the name of the principal. On the basis of this definition, the German commercial agent fulfils the requirements of article 13 of the AO. Section 222 of the EstR, however, stipulates that the commercial agent, as an independent entrepreneur, does not create tax liability on behalf of his foreign principal if he does not have a general authority to conclude contracts nor act as a delivery agent.

\subsection{SUMMARY}

The Agency PE concept was first introduced in German double taxation conventions in the late nineteenth century. The original concept recognised that it would make no difference whether a PE was actually run by the entrepreneur himself or by his fully empowered permanent representative. For the purpose of this study, this concept of the agent acting instead of the principal has been called the replacement theory.

The German Income Tax Act of 1922 introduced the Agency PE into domestic legislation. After 1922, case law further developed the German Agency PE concept. Post-war treaties followed the LON and OECD views on the Agency PE.

German domestic tax law contains a broader Agency PE concept. Article 13 of the AO defines the Agency PE for German tax laws and puts emphasis on the Weisungsgebundenheid. If the business instructions of the principal binds the agent, an Agency PE is likely to exist. In general, an independent agent that qualifies under the conditions of article 13 of the AO also constitutes an Agency PE. Because of German treaty policy, Section 222 of the EStR contains a limited exception to this rule. 



\section{The UK Agency PE Concept}

Avery Jones and Ward believe that the origin of paragraph 6 of article 5 of the OECD Model, which excludes brokers, commission agents and other agents with independent status from Agency $\mathrm{PE}$ status, can be traced back to developments in the UK at the beginning of this century. This chapter, therefore, will analyse UK law and treaty developments concerning the Agency PE concept. This analysis will be based on those of Avery Jones and Ward.

The Income Tax Act 1842 rendered any person not resident in the UK who was subject to taxation in respect of his profits or gains amenable to assessment by the Inland Revenue in the name of any factor, agent or receiver who received those profits or gains. Section 41 of the Income Tax Act 1842 reads:

"And be it enacted That the Trustee, Guardian, Tutor, Curator, or Committee of any Person, being an Infant, or Married Woman, Lunatic, Idiot, or Insane, and having the Direction, Control, or Management of the Property or Concern of such Infant, Married Woman, Lunatic, Idiot, or insane Person, whether such Infant, Married Woman, Lunatic, Idiot, or insane Person shall reside in Great Britain or not, shall be chargeable to the said Duties in the like Manner and to the same Amount as would be charged if such Infant were of full Age, or such Married Woman were sole, or such Lunatic, Idiot, or insane Person were capable of acting for himself; and any Person not resident in Great Britain, whether a subject of Her Majesty or not, shall be chargeable in the Name of such Trustee, Guardian, Tutor, Curator, or Committee, or of any Factor, Agent, or Receiver, having the Receipt of any Profits or

1 J.F. Avery Jones \& D.A. Ward, Agents as Permanent Establishments under the OECD Model Tax Convention, European Taxation, May 1993. 
Gains arising as herein mentioned, and belonging to such Person, in the like Manner and to the like Amount as would be charged if such Person were resident in Great Britain, and in the actual Receipt thereof; and every such Trustee, Guardian, Tutor, Curator, Committee, Agent, or Receiver, shall be answerable for the doing of all such Acts, Matters, and Things as shall be required to be done by virtue of this Act in order to the assessing of any such Person to the Duties granted by this Act, and paying the same."2

This quite lengthy provision shows that the roots of agency taxation in the UK originated in the tax authorities' need to find a way to collect taxes from nonresidents. The non-resident is thus charged in the name of his agent, "as if such person (the non-resident) were resident in Great-Britain".

Not without reason, the provision treats the agent in the same manner, for example, as it treats a guardian or curator, in other words, a person who has the power to act on behalf of another person. This person acts instead of the person he represents. During the discussions in the House of Commons on the 1915 Finance Act, representative Radford referred to section 41 of the Income Tax Act of 1842 and explained the meaning of this provision:

"The purport of the Clause is that whereas there were certain persons through whose hands passed the profits of a business not for their own advantage, but for the advantage of some other persons, and who in such cases were trustees for married women and infants or committees for lunatics, the Chancellor of the Exchequer said to the trustee or the committee that they should be chargeable with the tax in respect of those persons who were beneficiaries.".3

This is similar to the developments that were happening in Germany in those days. According to the replacement theory (see Chapter 3, paragraph 2), the agent who has the same powers as the entrepreneur himself creates tax liability for the foreign principal on this very basis. The 1842 UK provision is based on the same concept. Section 44 of the 1842 Income Tax Act states:

2 Section XLI Income Tax Act 1842 , Statutes at Large, United Kingdon of Great Britain and Irelond, 5 \& 6 Victoriae, Public General Acts, Sixteenth Volume, C.35. p. 135.

3 Finance (No. 3) Bill, House of Commons, The Parliamentary Debates (Official Report), Fifh Series, Volume LXXV, Eighth Volume of Session 1914-1915, p. 1875. 
"And it be enacted, That where any Person, being Trustee, Agent, Factor, or Receiver, Guardian, Tutor, Curator, or Committee of or for any Person, shall be assessed under this Act in respect of such Person, or where any Chamberlain, Treasurer, Cletk, or other Officer of any Corporation, Company, Fraternity, or Society as aforesaid, it shall be lawful for every such Person who shall be so assessed, by and out of the Money which shall come to his Hands as such Trustee, Agent, Factor, or Receiver, Guardian, Tutor, Committee, or Curator as aforesaid, or as such Chamberlain, Treasures, Clerk, or other Officer, to retain so much and such Part thereof from Time to Time as shall be sufficient to pay such Assessment; and every such Trustee, Agent, Factor, or Receiver, Guardian, Tutor, Committee, or Curator, Chamberlain, Treasurer, Clerk, or other Officer, shall be and is hereby indemnified against every Person, Corporation, Company, Fraternity, or Society whatsoever, for all Payments which he shall make in pursuance and by virtue of this Act."4

The law levied taxes on the agent for the profits that he collected on behalf of his foreign principal. The law assessed the agent as if he were the principal by granting him the power(s) to act 'instead of' the principal. The law authorised the agent to pay the taxes on these profits directly from these profits. Further, the law indemnified the agent against his principal who possibly did not agree with these payments.

A principal was assessable through his agent only if:

1. the sale contract was made in the UK, meaning that the sale contract was concluded and signed in the UK, but this did not mean that the non-resident himself had to be a party to it or even directly bound by it, and

2. the agent had receipt of the profits or gains. ${ }^{5}$

The last element (2) originated from section 41 of the 1842 Income Tax Act. The first element (1) originated also from the Income Tax Act. Non-residents were, and still are today, taxable on some UK sources of income. An important source is the source of income derived from trades, professions or vocations exercised within the UK. ${ }^{6}$ It confirms the principle that where the contract which gave rise to the trading profit was made in the United Kingdom then the

4 lbid. fn. 144, p. 136.

5 D. Waimman, "The Agent of a Non-Resident", The Tax Joumal, 27 April 1995, p. 9,

6 Schedule D, Case I and II, Income Tax Act. 
trade is likely to have been exercised in the United Kingdom. ${ }^{7}$ This principle is put into words by Brett L.J. in Erichsen v. Last in 1881:

"Now, I should say that wherever profitable contracts are habitually made in England by or for a foreigner with persons in England, because those persons are in England, to do something for or supply something to those persons, such foreigners are exercising a profitable trade in England, even though everything done by or supplied by them in order to fulfil their part of the contract is done abroad."

In Erichsen v. Last, a Danish telegraph company had offices in the UK where messages were received for transmissions overseas by the company's submarine cables. It was held that the company was carrying on a trade in the UK, even though the messages were transmitted around the world by the company's cables, which involved the company performing the contract with the customer outside the United Kingdom.

The reason behind point (2), the receipt of the profits as an important factor for the assessment of the agent, was clearly explained by Cockburn C. J. in Sulley $v$. Attorney-General:

"Wherever a merchant is established, in the course of his operations his dealing must extend (sic.) over various places; he buys in one place and sells in another. But he has one principal place in which he may be said to trade, viz., where his profits come home to him. That is where he exercises his trade. It would be very inconvenient if this were otherwise. If a man were liable to income tax in every country in which his agents are established, it would lead to great injustice.",

This seems to indicate primarily a choice of convenience. Taxes can only be collected if money, belonging to the non-resident, is present in the UK. Cockburn C. J. more or less states this accordingly in Sulley v. AttorneyGeneral:

7 E.C.D. Norfolk, Non-Resident: United Kingdon Trade, 1980 British Tox Review, p. 72.

8 Erichsen v. Last (1881) 4 TC 425-426 (CA).

9 Sulley w. Attoney-General (1860) 2 TC $149(\mathrm{ExCh})$. 
"How then are their [non-residents"] profits to be made amenable to the fiscal law? Simply by the provision that whosoever carries on the business and receives the profits here shall be assessed."10

A case where both principles, namely (1) the contract must be made in the UK and (2) the agent had receipt of the profits or gains, are simultaneously applied is Pommery and Greno v. Apthorpe (1886). ${ }^{11}$ A firm of French wine merchants employed an agent in the UK, who received orders from customers in the UK and collected the payments for wine sold in the UK. The wine was supplied either from the stock kept in England, or if it was a large order, the firm shipped the wine from France directly to the customer. The contracts in this case were concluded in England and the profits were received by the UK agent first. The High Court of Justice (Queen's Bench Division) held that the French firm's profits from the sale of wine in England, whether supplied from the stock in England, or shipped direct from France, were liable to tax assessment. More cases concerning French wine merchants were judged accordingly. ${ }^{12}$

The extent of the agent's authority to make the contract is not material if the contract is made by, or through, him. The UK agent may have full authority to make contracts for the sale (Watson v. Sandle \& Hull, 2 TC 611) or may only be in the position to accept the third party's offer when authorised to do so by the non-resident principal, as in Macpherson \& Co. v. Moore (6 TC 107). Moreover, even if the UK agent is merely the postbox through which the acceptance of the non-resident principal is communicated to the UK offeror, this will be sufficient for the contract to have been made in the UK through the UK agent. $^{13}$

10 rbid. fin. 151 .

11 Pommery and Greno v. Apthorpe (1886) 2 TC 182 (HC).

12. For example Tischler v. Apthorpe (1885) 2 TC 89 (HC); Wenle \& Co. v. Colquhoun (1888) 2 TC 402 (CA); Grainger and Son v. Gough (1896) 3 TC 462 (HL).

13 E.C.D. Norfolk, op cit., n. 7 , p. 74. 


\subsubsection{Introduction}

The provision of the 1842 Income Tax Act was amended by the Finance Act 1915 section 31. The Finance Act 1915 stated in section 31:

"(1) Section forty-one of the Income Tax Act, 1842 (which relates to the charge of income tax in special cases), shall, so far as it relates to the taxation of non-residents, be extended-

(a) so as to make non-resident persons chargeable to income tax in the name of any branch or manager as well as in the name of any factor, agent, or receiver; and

(b) so as to make non-resident persons so chargeable, although the branch, factor, agent, receiver, or manager may not have the receipt of the profits or gains of the non-resident.

(2) A non-resident person shall be chargeable in respect of any profits or gains arising, whether directly or indirectly, through or from any branch, factorship, agency, receivership, or management, and shall be so chargeable under section forty-one of the Income Tax Act, 1842, as amended by this section, in the name of the branch, factor, agent, receiver, or manager.

(3) Where a non-resident person not being a British subject or a British, Indian, Dominion, or Colonial Firm or Company, or branch thereof, carries on business with a resident person, and it appears to the Commissioners by whom the assessment is made that, owing to the close connection between the resident and the non-resident person, and to the substantial control ${ }^{14}$ exercised by the non-resident over the resident, the course of business between those persons can so be arranged, and is so arranged, that the business done by the resident in pursuance of his connection with the non-resident produces to the resident either no profits or less than the ordinary profits which might be expected to arise from that business, the non-resident shall be chargeable to income tax in the name of the resident person as if the resident person were an agent of the non-resident person.

(4) Where it appears to the Commissioners by whom the assessment is made or, on any objection or appeal, to the general or special

14 The author italicised certain passages in this paragraph. 
Commissioners that the true amount of the profits or gains of any nonresident person chargeable in the name of a resident person with income tax cannot in any case be readily ascertained the Commissioners may, if they think fit, assess the non-resident person on a percentage of the turnover of the business done by the non-resident person through or with the resident person in whose name he is chargeable, and in such case section fifty-three of the Income Tax Act, 1842, shall extend so as to require returns to be given on the business so done by the non-resident through or with the resident in the same manner as returns are to be given under that section of the profits or gains to be charged.

(5) The amount of percentage shall in each case be determined, having regard to the nature of the business, by the Commissioners by whom the assessment on the percentage basis is made, subject, in the case of an assessment made by the additional Commissioners, to objection or appeal to the general or special Commissioners.

If either the resident or non-resident person is dissatisfied with the percentage determined either in the first instance or on objection or appeal by the general or special Commissioners he may, within four months of that determination, require the Commissioners to refer the question of the percentage to a referee or board of referees to be appointed for the purpose by the Treasury, and the decision of the referee or board shall be final and conclusive.

(6) Nothing in section forty-one of the Income Tax Act, 1842, (as amended by any subsequent enactment or by this section) ${ }^{15}$, shall render a non-resident person chargeable in the name of a broker or general commission agent, or in the name of an agent, not being an authorised person carying on the non-resident's regular agency or a person chargeable as if he were an agent in pursuance of this section, in respect of profits or gains arising from sales or transactions carried through such a broker or agent.

(7) The fact that a non-resident executes salles or carries out transactions with other non-residents in circumstances which would make him chargeable in pursuance of this section in the name of a resident person shall not of itself make him chargeable in respect of profits arising from those sales or transactions." "16

15 The Income Tax Act of 1842 was still in force in 1915. The Finance Act of 1915 primarily dealt with an increase of income tax and an exiension of the taxable base.

16 Finance (No.2) Act, 1915, Chapter 89, 5 \& 6 Geo.5. The Law Reports 1914-1916, volume Lill, London 1916, p. 289 \& 290. 
This important article contains an extension as well as a limitation of the fiscal jurisdiction compared to the 1842 Income Tax Act. Both topics will be discussed in subsections 4.3.5 and 4.3.6.

During the parliamentary debates in the House of Commons the Chancellor of the Exchequer (Mr. McKenna) pointed to three cases which were the immediate cause for the new section 31 of the 1915 Finance Act.

\subsubsection{Case One}

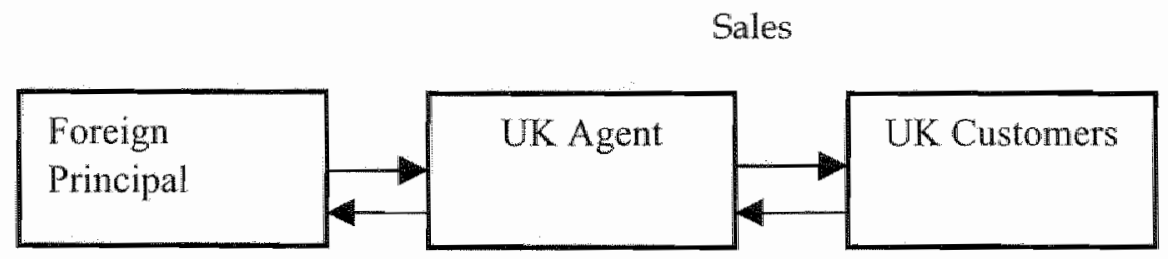

Orders

Orders

A foreign firm employs a UK agent and provides him with price lists and all the machinery required for receiving orders. The UK agent receives orders from UK customers and forwards the orders abroad. The agent has been carrying on trade in the UK, either in wholesale or retail, but does not effectively receive money or accept orders in this country. ${ }^{17}$ As paragraph 4.2 showed, under the 1.842 Income Tax Act the principal was only assessable through his agent if the sale contract was made in the UK and the agent received the profits or gains. In this case, the agent only obtains orders; the contract was concluded and signed abroad. Furthermore, the agent does not receive any profits or gains. He merely receives his commission. The profits of this trade thus escapes UK taxation because of a technicality in the law. The 1915 Finance Act altered this technicality through section 31 (1)(b), where the condition of the 1842 Income Tax Act, that the agent must receive the profits or gains, was dropped.

17 Ways and Means, Taxation of Non-Residents, House of Commons, The Parliamentary Debates (Official Report), Fifth Series, Volume LXXV, Eighth Volume of Session 1914. 1915, p. 664. 


\subsubsection{Case Two}

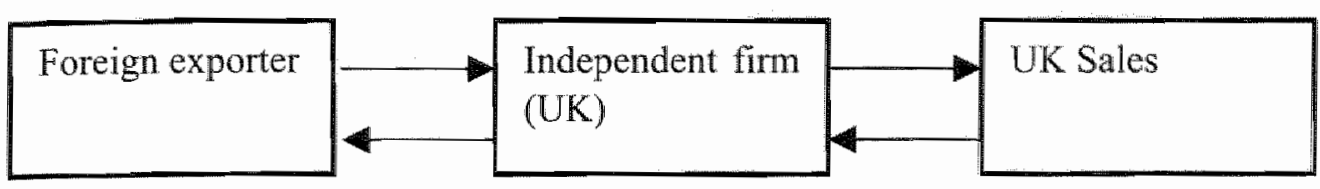

retail prices

(practically) no profits

This case deals with the following situation:

"a foreign exporter exports his commodities to an apparently independent firm carrying on business in the UK, but, owing to an arrangement between the exporter and the trader here, the goods or commodities are invoiced to the UK trader at or so near the price at which the trader can retail his goods or commodities to the public that the trader makes no profit. Although the foreign exporter and importer here may be making a gigantic profit, the whole of those profits, which are really made in the UK, escape taxation". 18

This case could be typified as a transfer pricing issue. Although the UK firm is supposed to be an independent firm, the only reason for this arrangement is some kind of association between the foreign exporter and the UK firm. This association would most probably be a participation of the foreign exporter, directly or directly, in the management, control or capital of the UK firm. ${ }^{19}$ The prices between the foreign exporter and the UK firm are clearly not at arm's length and should be adjusted accordingly.

18 Ibid, fin. 159, p. 665.

19 According to Art. 9 of the OECD Model. 


\subsubsection{Case Three}

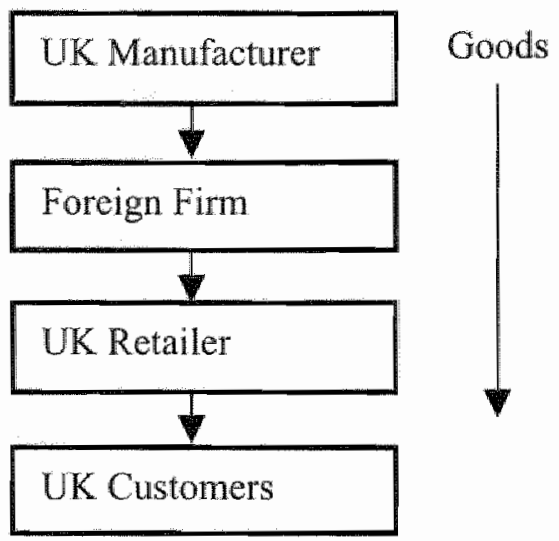

In this final case the goods are manufactured in the UK. They may be sold by the manufacturer to a foreign firm, and the foreign firm may resell them to the retailer, but at such prices as to show no profit except to the firm abroad, and thus Income Tax is avoided. It is likely that the goods may never leave the $\mathrm{UK}^{20}$ Like in case two, this case also deals with transfer pricing issues. Through this concoction the inter-company prices between the foreign firm and the UK retailer are almost the same as retail prices, so almost no profits are generated if the UK retailer sells the products to a UK customer.

Section 31 (3) FA 1915 gives the Inland Revenue the power to tax profits in this case where no profits, or less than the ordinary profits which might be expected, arise in the UK.

\subsubsection{Extending the Taxable Base of Non-residents}

\subsubsection{Not Receiving the Profits}

Section 31 paragraph l(b) extended the scope for assessment of a non-resident in the name of an agent by removing the restrictive requirement concerning actual receipt by the agent of the profits or gains in question. ${ }^{21}$ This was obviously to

20 lbid, fin. 159 , p. 665 .

21 D. Davies, Booth: Rexidence, Domicile and UK Taxation, 2 nd ed. (Butterworths, London, 1995), p. 21.5. 
counter, what I would like to call, 'case one' tax avoidance. According to Norfolk, in all the cases where the receipt of proceeds of sale was mentioned as a factor contributing to the trade being exercised in the UK, the contracts were made in the UK. ${ }^{22} \mathrm{So}$, under the general source rules a UK trade was likely to exist if the contract, for example a contract of sale, was made in the UK. This could lead to the conclusion that the receipt of the sale proceeds by a UK agent was by no means an overwhelming factor and could perhaps therefore be easily omitted from the new proviso of the 1915 Finance Act.

\subsubsection{Branch or Manager}

Section 31 paragraph1(a) creates tax liability for the foreign entrepreneur who works through a UK branch or manager. The 1842 Income Tax Act did not contain a provision which dealt with the taxation of the foreign entrepreneur who had a branch in the UK. The extension to this effect in the 1915 Finance Act broadened the taxable base to, what we call today, the permanent establishment (branch) and the agency PE. According to Davies ${ }^{23}$, this provision gives the Inland Revenue power to assess a non-resident in the name of almost anyone with whom he has dealings in the UK - a solicitor, an accountant, a stockbroker, an insurance broker or even a bank - but the provision is, in fact, limited in various ways, both from within and from without legislation.

\subsubsection{Anti-avoidance Legislation}

Section 31 (3) FA 1915 could be distinguished as being early anti-avoidance legislation. If a non-resident conducted his business in the UK through a resident person and met the three conditions contained in paragraph 3 , he would be taxed in the name of the resident. Interestingly, paragraph 3 treated the resident person as if he was an agent. So, this kind of middleman was not legally an agent but for tax purposes was treated as if he was an agent.

The three conditions were:

1. there must be a close connection between non-resident and resident;

2. the non-resident has substantial control over the resident, and

3. the domestic business leads to no profits or less than might be expected.

22 E.C.D. Norfolk, op cit., n. 7, p. 79.

23 D. Davies, op cit., n. 21, p. 216. 
If a contract was made in the UK on behalf of a non-resident person, this could mean that the resident person acted as an agent, thus creating tax liability for the non-resident.

This did not mean that only persons who had the authority to conclude contracts would create tax liability for the non-resident principal. Section 31 paragraph 3 is proof of this assumption. If a non-resident trader consigned goods to a UK agent, and the agent sold the goods on certain terms and certain prices, the nonresident was held to be trading in the UK through an agent if a proportion of the proceeds of the sale would be for the account of the non-resident. ${ }^{24}$

The case two and three evasion techniques were covered by paragraph 3 . This paragraph was designed to put an end to clear evasions by means of bogus companies, according to one of the members of the House of Commons. ${ }^{25}$ It was described as follows:

"If the agent is doing a bonâ-fide business and receiving his 1 percent, the ordinary trade retum, there will be no more Income Tax charged, except on the agent's profit of 1 per cent. But if there is a collusive arrangement whereby the agent gets no profit, he will be charged in respect of the proper profit of the agent." 26

Paragraph 3, therefore, also stipulated that in this case "the non-resident shall be chargeable to income tax in the name of the resident person as if the resident person were an agent of the non-resident person". This would implicate two tax corrections: (1) taxing the agent on a fair market value commission, and (2) taxing the foreigner on his UK profits, in the name of the resident person, as if they were generated by means of a UK agent.

The Chancellor of the Exchequer explained the meaning of the phrase "substantial control":

"In practice it means a subsidiary company in which a great majority of the shares are owned by the parent company so that the subsidiary company makes no profit, but buys the goods from the parent company at a price where all the profits go to the parent company abroad. 
I think the words "substantial control exercised by the non-resident over the resident' bring up many cases which are familiar to us all. The nonresident holder in a British company, or the non-resident, may be the principal partner in a firm which carries on business here and substantially controls the firm. We are putting in the word 'substantial' in order to avoid one rather obvious means of escape."27

The former UK legislators were clearly opposed to improper use of the agency taxation rules. If foreign entrepreneurs wanted to avoid UK taxation using frontmen or bogus companies, the introduction of section 31 (3) Finance Act 1915 prohibited those very avoidance methods. Essential in this provision is the 'control" aspect. If the foreign entrepreneur had control over the UK person in such a way that he could determine the inter-company prices, section 31 (3) would be applicable.

\subsubsection{Limiting the Taxable Base of Non-residents}

\subsubsection{Exclusion of the Broker and General Commission Agent}

Section 31(6) FA 1915 reads:

"(6) Nothing in section forty-one of the Income Tax Act, 1842, (as amended by any subsequent enactment or by this section $)^{28}$, shall render a non-resident person chargeable in the name of a broker or general commission agent, or in the name of an agent, not being an authorised person carying on the non-resident's regular agency or a person chargeable as if he were an agent in pursuance of this section, in respect of profits or gains arising from sales or transactions carried through such a broker or agent."

A new element in the 1915 provision was the rule that a non-resident person was not to be chargeable in the name of a broker, including the general commission agent. The reason that business transactions made by a non-resident through a UK broker or commission agent escaped UK taxation in the 1915

27 Finance (No.3) Bill, House of Commons, Considered in Committee, The Parliamentary Debates (Official Report), fifth Series, Volume LXXV, Eight Volume of Session 1914-1915, p. $1891 \& 1901$.

28 The Income Tax Act of 1842 was still in force in 1915. The Finance Act of 1915 primarily dealt with an increase of income tax and an extension of the taxable base. 
Finance Act was purely an economic one. A vast quantity of business was being done in the City of London by stockbrokers who, on behalf of foreign capitalists and foreign banks, bought and sold enormous quantities of investments and securities on the London Stock Exchange. Millions" worth of all kinds of fruit, vast quantities of bacon and provisions, and other articles of that sort were sold every week in London, Liverpool and other similar markets, by brokers for foreign owners for sale and return. ${ }^{29}$

A broker is essentially an intermediary acting for both the parties to a contract where it is his business to bring them together. Brokers do business in such branches of commercial activity as stock and share dealing, insurance, and above all the buying and selling of many kinds of commodities. ${ }^{30}$

The term "general commission agent" was used in those days as a another word for "factor". The factor is an agent entrusted with the possession of goods, or documents of title representing goods, for the purpose of sale. A factor is likely to fall within the definition of a mercantile agent in the Factors Act 1889 and to have the powers of the mercantile agent. A mercantile agent has authority either to sell goods, to consign goods for the purpose of sale, to buy goods or to raise money on the security of goods on behalf of his principal. The consignment of goods means keeping the goods on behalf of the consignor.

A factor has a lien ${ }^{31}$ over the goods entrusted to him that covers any claims against the principal arising out of the agency. A lien is the right of one person to retain possession of goods owned by another until the possessor's claims against the owner have been satisfied. ${ }^{32}$

The word "general" indicated that the commission agent worked for clients in a manner common to brokers, meaning he worked for any number of clients. The common opinion was that a general commission agent should have broker-like qualities. ${ }^{33}$ As Megarry J. expressed it in the Fleming versus London Produce Co. Ltd case:

29 lbid., fin. 159 , p. 878 .

30 Especially raw materials such as cotton, wool and colonial produce.

31 Lien is an English tern which originated, through old French, from the Latin-word liganen, meaning "a binding".

32 E.A. Martin, A Dictionary of Law, 3 rd ed. (Oxford University Press, 1994).

33 Cf. Fleming versus London Produce (1968) 44 TC 582. 
"...the general trend of the proviso" is to confer exemption on non-residents who merely employ brokers for broking in the ordinary way, even if they regularly employ the same one. The words "ordinary course of his business', "carrying on bona fide the business' and 'a rate not less than that customary in the class of business in question" seem to me to be significant: in relation to broking the proviso is redolent of ordinariness.

Third, the word 'general" in the phrase general commission agent itself must have the same import; and in the context I think the most likely sense is that of a commission agent who holds himself out as being ready to work for clients generally, and who does not in substance confine his activities to one principal, or even an insignificant number of principals. This is perhaps another fact of his broker-like qualities: he must be broker-like in the receipt of custom., ${ }^{, 35}$

That being the case, a non-resident could not escape taxation by virtue of the proviso if, in substance, he carries on business within the UK through the medium of an agent who is virtually a sole agent, running the entire business for him and merely sending him remittances on request. ${ }^{36}$ This being proven by the facts of Fleming v. London Produce Co. Ltd.

London Produce Ltd. was a UK company that imported meat from New Zealand for sale in London. It dealt entirely with a New Zealand company ( $\mathrm{N}$ Ltd.) which bought the meat from farmers. London Produce conducted $95 \%$ of its business on behalf of a South African Company ( $K$ Ltd.) and the remaining $5 \%$ on behalf of independent farmers acting through $\mathrm{N}$ Ltd. The company paid for the meat on behalf of $\mathrm{K} \mathrm{Ltd}$. through letters of credit in New Zealand entitling a bank to pay $\mathrm{N}$ Ltd. on behalf of K Ltd. London Produce paid the freight from New Zealand to London and arranged and paid for marine assurance. The balance of the proceeds of sale, less freight and insurance charges and the company's own commission was held by London Produce in London to the credit of K Ltd. as and when K Ltd. required. The company's bookkeeping was appropriate to consignment sales on behalf of a principal. $A$ fascinating detail was that London Produce Ltd., K Ltd. and $\mathrm{N}$ Ltd. were all under the shareholding control of one family. The court held that London

34 This refers to the UK domestic provision which excluded the broker and general commission agent from the Agency PE status. This clause was based on the 1915 Finance Act provision.

35 Fleming versus London Produce (1968) 44 TC 582, at 596.

36 E.C.D. Norfolk, op cil., n. 7, p. 77. 
Produce Ltd. was acting as an agent for K Ltd., and not as a principal, and that it was neither a broker nor a general commission agent.

In this sense, the "broker-like qualities" of the general commission agent mentioned before, points to the fact that the general commission agent, as the broker, works for a significant number of principals. A general commission agent does not act exclusively for only one principal. However, there was a significant difference: the factor usually sold goods in his own name without disclosing the existence of his principal (owner of the goods), whereas the broker sold the goods in the name of his principal. The commission agent, like the factor, concludes contracts in his own name and does not bind or entitle his principal. $^{37}$

I conclude from the facts of Fleming v. London Produce Co. Ltd. that London Produce Co. Ltd. sold the meat in its own name but was not considered to have broker-like qualities, in the sense that they worked solely for one principal. All. the companies involved were controlled by one family.

"General" commission agents were exempted because, with emphasis on "general", they acted for any number of principals. The commission agent who acted exclusively for one principal, and thus was not being regarded as a "general" commission agent, was not exempted from taxation of the nonresident principal.

\subsubsection{Other Agents}

Section 31 (6) also excludes from the Agency PE taxation the non-resident who conducts his business through an agent "not being an authorised person carrying on the regular agency of the non-resident person".

The Chancellor of the Exchequer explained the meaning of this provision:

"The effect is to exclude all agency transactions, except such transactions as come within the existing law - that is to say, it must be a regular constituted agent in order to bring the relations between the foreign resident and the agent under the conditions of taxation prescribed by this clause and the Act of $1842 ., 38$

37 H.L.E. Verhagen, Agency in Private International Law, p. 36.

38 Finance (No. 3) Bill, House of Comnons, The Parliamentary Debates (Official Report), Fifth Series, Volume LXXVI, Ninth Volume of Session 1914-1915, p. 1203. 
The discussion in the House of Commons focused around the distinction between an agent and an agency. According to the Chancellor of the Exchequer:

"An agent may be a person who is ordinarily and regularly employed as an agent, but he may not be conducting an agency. It is really a sort of branch business. In conducting a regular agency a man is doing something more than acting as an agent." ${ }^{.39}$

Scrutton J. gave his view on this issue in Nielsen, Andersen \& Co. $\%$. Collins:

"The words "not being an authorised person carrying on the non-resident's regular agency' apply to the whole of the preceding descriptions, and the contrast intended to be drawn is between casual employment, temporary employment, for a transaction or a few transactions, and regular appointment of a permanent agent who is there as representing the foreigner... I think the distinction is between the casual agent and the authorised person carrying on the non-resident's regular agency."40

This seems to indicate that an agency relationship had to be of a certain permanency which then constituted a taxable presence for the principal. One-off deals and temporary arrangements are apparently excluded. This could mean that this provision is the basis for the current Agency $P E$ requirement which can be found, for example, in the OECD Model, namely the condition that the agent must "habitually exercise" the authority to conclude contracts.

\subsubsection{The Double Foreigner Exemption}

Section 31 (7) contained the "double foreigner exemption". The double foreigner exemption was clarified as follows:

"Those words exclude the case of an agent or auctioneer who is simply acting in this country as the middleman between, for example, the Australian seller of wool on the one hand and the French purchaser on the other... Where the transaction is not really one in which the profits in the

39 Ibid., in. 159, p. 1209.

40 Nielsen, Andersen \& Co. Collins (1926) 13 TC 91 (CA). 
true sense of the word are earned in this country, we do not propose to $\operatorname{tax}^{.41}$

This provision seems to be based upon an economic view. If the foreign entrepreneur undertakes economic activities (by using some sort of agent) in such a way that these activities really create UK profits, taxation would be in order. The use of an agent merely as a middleman in a foreign-to-foreign transaction was not considered to justify British taxation. This kind of middleman was really a broker. According to Pollock: "...a broker has no authority to receive payment."42

A good example of the application of the double foreigner exemption can be found in early UK case law. In Maclaine \& Co. v. Eccott ${ }^{43}$, a Java firm of general merchants and commission agents sold East Indian produce, mainly sugar, in London through an associated London firm as its agent, sometimes on their own account and sometimes as agents for planters. The sales were effected in a variety of ways. One of these ways was that the London firm sold, on commission, sometimes through brokers, goods bought, or to be bought, by the Java firm who consigned them direct to the purchasers, whether in the UK or elsewhere. The contracts for sale were made in the UK. Payment was effected by the purchasers providing a credit with a London bank upon which the Java firm drew. The London firm always purported to act as agents for the Java firm, and the latter invariably controlled the price at which the goods were sold. With regard to the transactions mentioned above, the court held that, in view of the provisions of section 31 (7) of the Finance Act 1915, the profits arising from the Java firm's sales to non-residents through the agency of the London firm should, where these profits were not received by the London firm, be excluded from LKK taxation.

\subsection{THE FINANCE ACT 1925}

The Finance Act 1925 adhered to the same principles embodied in the Finance Act 1915. Section 17, paragraphs 1-3, of the Finance Act 1925, reads:

4.1 lbid, fn. 159, p. 1860.

42 lbid. fn. 159 , p. 1137.

43 Maclaine \& Co. v. Eccott (1926) 10 TC 481 (HL). 
"(1) Where sales or transactions are carried out on behalf of a non-resident person through a broker in the ordinary course of his business as such, and the broker satisfies the conditions required to be satisfied for the purpose of this section, then, notwithstanding that the broker is a person who acts regularly for the non-resident person as such broker, the non-resident person shall not be chargeable to income tax in the name of that broker in respect of profits or gains arising from those sales or transactions.

(2) The conditions required to be satisfied for the purposes of this section are that the broker must be a person carrying on bona fide the business of a broker in Great Britain or Northern Ireland, and that be must receive in respect of the business of the non-resident person which is transacted through him remuneration at a rate not less than that customary in the class of business in question.

(3) In this section the expression 'broker' includes a general commission agent." 44

Mitchell B. Carroll pointed out the reason for this exemption clause:

"As London was the centre for the entrepôt trade in raw materials of all kinds, the heads of the tax administrations of the European countries who attended in the early 1920 s the meetings of the LON Committee of Technical Experts sought to prevail upon the British menber to restore the exemption of non-residents selling such materials through bona fide commission agents or brokers in London or other British trading centres. This lead to amending the UK income tax act to exempt such transactions under certain conditions. ${ }^{, 45}$

In this provision, the exempted broker and, through paragraph 3, general commission agent must act in the ordinary course of their business. This condition is still in force today, as article 5 paragraph 6 of the OECD Model Treaty proves.

44 Finance Act 1925, the Law Reports, The Public General Statutes, Volume II, Chapter 36, Eyre and Spottiswood limited, London 1925, page. 1119.

45 Mitchell B. Camroll, 'International Tax Law, 2'Inermational Lawyer 692, 1968. 
Paragraph 2 points to the bona fide agent, as we will see in the League of Nations draft convention of 1927. Secondly, the agent must receive a customary remuneration. During the parliamentary debates, the Financial Secretary to the Treasury (Mr. Guinness) stated:

"The exemption applies to agents who are paid commission agents, and salaried agents." 46

The question as to what a customary remuneration actually is must be answered from an objective point of view. As the text clearly shows, the remuneration must be compared with a remuneration customary in the class of business in question.

The phrase used in paragraph 1 ("in the ordinary course of his business as such"), points to a objective perspective in looking at the "ordinary course of business'. The 'business as such' puts emphasis on the business of the broker. The remarks of the Financial Secretary to the Treasury (Mr. Guinness) during the parliamentary debates were very interesting. He states: "Where the agent acts exclusively for the particular non-resident principal he will, of course, remain liable for the Income Tax of that principal. ${ }^{, 47}$

This statement is very clear, only agents who are acting for a number of clients are exempted. The broker who acts solely for one principal is not exempted.

\section{5}

\section{TAXES MANAGEMENT ACT 1970}

The provisions of the Finance Act 1925 applied until 1970. Section 78(1) of the Taxes Management Act 1970 (TMA) stated that:

"...a person not resident in the United Kingdom, whether a British subject or not, shall be assessable and chargeable to income tax in the name of any such trustee, guardian, tutor, curator or committee..., or of any branch or agent, whether the branch or agent has the receipt of the profits or gains or not, in like manner and to the like amount as such non-

46 Finance Bill, House of Commons, The Parliamentary Debates (Official Report), Seventh Volume of Session, 1924-1925, p. 1132.

47 Finance Bill, House of Commons, The Parliamentary Debates (Official Report), Seventh Volume of Session, 1924-1925, p. 1123. 
resident person would be assessed and charged if he were resident in the United Kingdom and in the actual receipt of such profits or gains. 48

This provision is very wide indeed and gives the Inland Revenue the power to assess a non-resident in the mame of almost anyone with whom he has dealings in the United Kingdom - a solicitor, an accountant, a stockbroker, an insurance broker or even a bank - but the provision is, in fact, limited in various ways, both from within and from without the legislation. ${ }^{49}$

The first limitation can be found in section 79 of the TMA. where it is formulated that:

"a non-resident person shall be assessable and chargeable to income tax in respect of any profits or gains arising, whether directly or indirectly, through or from any branch or agency, and shall be so assessable and chargeable in the name of the branch or agent."

Only profits earned through the UK agency are taxable. This visualises the connection necessary between the agent and the profits to make the agent the assessable agent for those profits. Sully v. Attorney-General (1860) demonstrated the essence of this provision. Sulley was a partner in a firm of general merchants and drapers which carried on business in the United States and England. Sully resided in the UK and all the other partners in the US. In England, Sulley transacted the business of the firm, which consisted of purchasing and shipping goods for export. The profits were made by the re-sale of goods purchased in the US, France and Germany. The Exchequer Chamber ruled that only the share ${ }^{50}$ in the company belonging to the partner resident in the UK. (Sulley) was liable to tax. No other profits were taxable in the UK. Cockburn explained this ruling as follows:

"The profits of the firm in America do not accrue in respect of any trade carried on in this country, but in respect of the trade carried on in New York, where the main business is conducted." 51

\footnotetext{
48 Taxes Management Act 1970 section 78(1), The Public Gencral Acts 1970, part I, Council of Law Reporting, London 1970, p.81.

49 D. Davies, op cit., n. 21, p. 216.

50 Meaning part of the total profits of the firm which Sulley as a partner was antitled to.

51 Sulley w. Attomey-General (1860) 2 TC 149 (ExCh).
} 
The profits must accrue in the UK, or in other words, the profits must develop and accumulate through the UK branch or agency. Cockburn clearly refers to the main business. The agent's profits are linked to the main business of his foreign principal.

Not every kind of agent creates tax liability for his foreign principal. Rowlatt stated in Nielsen, Andersen \& Co. v. Collins:

"Nobody would dream of charging an agent in respect of profits or gains that did not arise from sales or transactions carried out through him. ${ }^{.52}$

Another important limitation to section 78(1) of the TMA can be found in section 82(1):

"Nothing in this Part of this Act shall render a non-resident person chargeable in the name of a broker or in the name of an agent not being an authorised person carrying on the regular agency of the non-resident person, in respect of profits or gains arising from sales or transactions carried out through such broker or agent:

Provided that where sales or transactions are carried out on behalf of a non-resident person through a broker in the ordinary course of his business as such and the broker-

(a) is a person carrying on bona fide the business of a broker in the United Kingdom, and

(b) receives in respect of the business of the non-resident person which is transacted through him remuneration at a rate not less than that customary in the class of business in question, then, notwithistanding that the broker is a person who acts regularly for the non-resident person as such broker, the non-resident shall not be chargeable in the name of that broker in respect of profits or gains arising from those sales or transactions.

In this subsection, 'broker' includes a general commission agent."

This provision is based on section 31 (6) of the Finance Act 1915 and section 17 (1-3) of the Finance Act $1925 .{ }^{53}$ All the provisions in the TMA are assessment provisions and not charging provisions. None of the provisions can impose a tax

52 Nielsen, Andersen \& Co. v. Collins (1926) 13 TC 91 (CA).

53 See para 4.3 of this chapter. 
charge which would not occur if the TMA provisions were not present. The basis for the non-resident tax liability is found in the Income and Corporation Taxes Act, not the TMA.

The other limitation in the TMA is the exclusion of agents for "double foreigner transactions" (section 82(2) of the TMA). Section 82(2) of the TMA reads:

"The fact that a non-resident person executes sales or carries out transactions with other non-residents which would make him chargeable in pursuance of this Part of this Act in the name of a resident person shall not of itself make him chargeable in respect of profits arising from those sales or transactions."

The double foreigner exemption originated from section $31(7)$ of the Finance Act 1915. The intention and effect of section 82(2) of the TMA is to exempt from taxation in the name of a resident agent those cases where that agent is not in receipt of the profits. ${ }^{54}$

This exemption was applied in Muller \& Co. Ltd. v. Lethem (1927). In this case, a UK company acted as agent for a Dutch shipping line operated by two Dutch companies, which attended to all matters relating to passenger and goods traffic on the line between London and Rotterdam, including, in certain cases, the collection of freight and fares. It was held that the Dutch companies were exercising a trade in the UK through the UK company in whose name they were assessable to income tax, except in relation to profits from shipments under contracts made with non-residents where the proceeds were not received by the UK agent company. ${ }^{55}$

Section 118 (1) of the TMA 1970 states that for the application of the TMA:

" "branch or agency" means any factorship, agency, receivership, branch or management, and 'branch or agent' shall be construed accordingly." 56

54 Viscount Cave L.C. thus concluded, based upon section 31(7) Finance Act 1915, in the case of Maclaine v. Eccott (1926) $10 \mathrm{TC} 481$ (HL).

55 E.C.D. Norfolk, op cit, n. 7, p. 92.

56 Taxes Management Act 1970 section 118(1), Halsbury's Statunes of England and Wales, fourth ed.(Butterworths, London, 1996), p. 323. 
The basis for the non-resident tax liability is primarily codified in the Income and Corporation Tax Act. Companies not resident in the UK are taxable according to section 11(1) Income and Corporation Taxes Act 1988 (ICTA):

"A company not resident in the United Kingdom shall not be within the charge to corporation tax unless it carries on a trade in the United Kingdom through a branch or agency, but, if it does so, it shall, subject to any exceptions provided for by the Corporation Tax Acts, be chargeable to corporation tax on all its chargeable profits wherever arising."

This provision refers to the source of taxable income under Schedule D of the ICTA.

Schedule D rules that:

"Tax under this Schedule shall be charged in respect of-

(a) the annual profits or gains arising or accruing-

(i) ...

(ii) ...

(iii) to any person, whether a Commonwealth citizen or not, although not resident in the United Kingdom from any property whatever in the United Kingdom or from any trade, profession or vocation exercised within the United Kingdom, and..." 58

The computation rules for these categories of income are broadly the same as those for residents. However, unlike the case for residents, income or corporation tax liability in respect of a non-resident's trading profits depends on where the trade is exercised: unless exercised in the UK, the profits are no: taxable.

57 Halsbury"s Siames of England and Wales, volume 44, 1996 reissue, fourth ed. (Butterworths, London, 1996), p. 41 .

58 Lord Hailsham of StMarylebone, Harsburys Laws of England, volume 23, fourth ed. reissue (Butterworths, London, 1991 ).

59 B. Larking in Pennanent Eshablishment loose-leaf edition, United Kingdom chapter (IBFD, Ansterdam, 1996). 
The Finance Act 1995 (FA 1995) repealed sections 78-85 of the TMA 1970 for the purpose of income tax and capital gains tax for the years 1996-1997. These new rules are contained in section 126, 127 and Schedule 23 of the FA 1995. The concept of 'UK representative' was created, meaning the branch or agency through which trade is carried on. A special compliance regime exists for UK representatives. ${ }^{60}$

The basic rule in FA 1995 is laid down in section 126(1):

"Schedule 23 to this Act shall have effect for imposing obligations and liabilities in relation to income tax, corporation tax and capital gains tax on a branch or agency which, under this section, is the UK representative of a person who is not resident in the United kingdom ("the non-resident')."

Section 126(8) of the FA 1995 states that "branch" or "agency" in this section has the same meaning as in the TMA. So the FA 1995 holds no new views on the range of the UK agency concept. Schedule 23 contains extensive rules concerning obligations imposed on UK representatives, varying from rules regarding criminal offences, penalties and indemnities to general imposition of obligations and liabilities.

4.8

\section{THE UK AGENCY CONCEPT IN DOUBLE TAXATION CONVENTIONS}

\subsubsection{Introduction}

Whereas Germany concluded double taxation conventions as early as 1899 (double taxation conventions between Prussia and Austria/Hungary), The UK started concluding specific taxation conventions from the 1930s. Although the UK did have commercial and trade conventions before 1900, they did not contain specific tax provisions for the prevention or avoidance of double taxation. The UK is the first State (with Norway) that concluded a specific tax convention solely for the purpose of agency taxation. The convention was

60 S. Hoyle, 'Connecting factors for UK corporate tax", International Tax Review, April 1996, p. 45. 
signed in London on 21 December 1938. It was officially called: Agreement between the Government of the United Kingdom and the Norwegian Government for the exemption from taxation of profits or gains arising through an agency (1938 Agency Convention). ${ }^{61}$

\subsubsection{Agency Tax Convention (1938)}

\subsubsection{Provisions}

This agreement was concluded for reciprocal exemption from taxes in certain cases of profits or gains arising through an agency. Article 1 defines the UK standpoint in the relationship with Norway concerning the agency exemption:

"The Government of the United Kingdom of Great Britain and Northern Ireland undertakes that the profits or gains to which this Article relates shall, so long as the exemption specified in Article 2 hereof remains effective, be exempted from Income Tax (including Surtax) chargeable in the United Kingdom for the year of assessment commencing on the sixth day of April, nineteen hundred and thirty-five, and for every subsequent year of assessment, and will take the necessary action with a view to giving the force of law to the exemption aforesaid.

The profits or gains to which this article relates are any profits or gains from the sale of goods arising, whether directly or indirectly, through an agency in the United Kingdom, to a person who is resident in Norway and is not resident in the United Kingdom, unless the profits or gains either-

(a) arise from the sale of goods from a stock in the United Kingdom; or

(b) accrue directly or indirectly through any branch or management in the United Kingdom or through an agency in the United Kingdom where the agent has and habitually exercises a general authority to negotiate and conclude contracts."

Article 2 of the convention is a kind of mirror of article 1. Article 2 deals with the Norwegian agent who acts on behalf of a UK principal. Article 3 reads:

61 Treaty Series No.11 (1940), Cnd. 6195, London, December 21, 1938. 
"The Royal Norwegian Government undertakes that..., profits or gains accruing to a person, resident in the United Kingdom and not resident in Norway, from sales under contracts entered into in the United Kingdom (that is to say, where the acceptance of the offer is effected in the United Kingdom) of goods stocked in a warehouse in Norway for convenience of delivery and not for purpose of display, shall be exempted from Norwegian Income Tax even though the offers of purchase have been obtained by an agent in Norway of the principal in the United Kingdom and transmitted by him to the principal for acceptance..."

Article 4 deals specifically with independent agents. It reads:

"...if a person resident in Norway and not resident in the United Kingdom carries out sales in the United Kingdom through a broker or general commission agent acting in the ordinary course of his business as such, then, notwithstanding that the sales are made from a stock of goods in the United Kingdom or that the broker or general commission agent is a person who acts regularly for the Norwegian principal in such capacity, the broker or general commission agent is not chargeable to United Kingdom Income Tax (including Surtax ${ }^{62}$ ) on behalf of the Norwegian. principal in respect of profits or gains derived by the Norwegian principal from those sales; provided that the broker or general commission agent is a person carrying on bona fide the business of a broker or general commission agent in Great Britain or Northern Ireland, and that he receives remuneration in respect of the business of the Norwegian principal transacted through him at a rate not less than that customary in the class of business in question."

\subsubsection{Analysis}

According to article 1 of the convention, looking from the UK point of view, a Norwegian principal who has a UK agency is exempt from UK income tax on profits derived from that agency. This does, however, not apply in two separate

62 Sur-tax is an extra or additional tax. Specifically it is a graduated income tax over and above the usual or fixed income tax, levied on the amount by which net income exceeds a certain sum.

63 The second part of Article 4 contains the exact same provision as the cited part, but in this case for the UK principal who conducts business in Norway through a Norwegian broker or general commission agent. 
cases: (a) when the profits arise from the sale of goods in the UK; or (b) in the case of a UK branch or management or agency. The agency is described in the provision as an agent who has and habitually exercises a general authority to negotiate and conclude contracts. The agent concluding contracts "in the name of" the principal is not mentioned but it seems likely that this would be the case in view of the general authority.

The thus construed tax base is limited in article 4 of the convention. This provision contains an exemption for the Norwegian principal who conducts his business in the UK through a genuine broker or general commission agent. Article 4 seems to be copied from Section 17 (1-3) of the 1925 Finance Act. The conditions which must be met are the same:

(1) the broker or general commission agent is a person genuinely carrying on the business of a broker or general commission agent, and

(2) he must receive a customary remuneration.

If the ordinary course of the business of, for example, the general commission agent is to sell goods from a stock held in the UK, that last fact does not endanger the exemption.

Mitchell B. Carroll wrote in 1939 that a PE would exist if an agent:

(1) is a duly accredited agent who habitually enters into contracts for the enterprise for which he works;

(2) is bound by an employment contract and habitually contracts commercial business on behalf of the enterprise in return for remuneration, or

(3) is habitually in possession, for the purpose of sale, of a depot or stock of goods belonging to the enterprise. ${ }^{64}$

It is likely that Mitchell B. Carroll and the League of Nations were influenced by this UK Agency Convention and UK domestic tax laws.

Article $1(a)$ of the 1938 Agency Convention is similar to Mitchell B. Carroll's third point. Article 1 (b) of the 1938 Agency Convention entails the same concept as that in points (1) and (2) described by Mitchell B. Carroll. The agent

64 Prevention of International Double Taxation and Fiscal Evasion, Two Decades of Progress under the League of Nations, Mitchell B. Carroll, Official no.: F./Fiscal/111, Geneva, June 22nd, 1939 , pages $32 \& 33$. 
who "has and habitually exercises a general authority to negotiate and conclude contracts" is a description of an Agency PE which is almost the same as the Agency PE provision of the 1995 OECD Model. The term "duly accredited. agent" points to the agent who has sufficient authority to conclude contracts "in the name of" the principal.

This convention contains two Agency PEs, namely the agent who concludes contracts and the agent who is selling from a stock of goods. All other profits which are generated through an UK agent, are exempt from UK income taxation. If the agent, for example, makes sales from a stock of goods, the profits could nevertheless be exempt from UK taxation if the UK agent is a broker or generall commission agent.

The starting point of the Agency PE provision in this convention is typical. All the UK profits a foreigner creates through a UK agent is exempt from UK income taxes, except if the agent is an agent concluding contracts or filling orders from a stock of goods.

\subsubsection{Treaty Policy from $1940-1960$}

An example of an Agency PE provision in a UK tax treaty in the 1940 s can be found in the 1945 treaty with France. Article 4 of the UK-France double taxation convention reads:

"The profits or gains described in the following paragraph shall be exempted in the United Kingdom from Income Tax (including Surtax).

The profits or gains to which this Article relates are any profits or gains from the sale of goods arising, whether directly or indirectly, through an agency in the United Kingdom to a person resident in France, unless the profits or gains either:

(i) arise from the sale of goods from a stock in the United Kingdom, or (ii) accrue directly or indirectly through any branch or management in the United Kingdom where the agent has and habitually exercises a general authority to negotiate and conclude contracts."

65 Agreement between His Majesty in respect of the United Kingdom and the Head of the Provisional Government of the French Republic for Relief from Double Traxation in certain circumstances of Individuals and Comparies in the United Kingdom of Great Britain and Northern Ireland and France respectively, Paris, 19th October, 1945, Treaty Series No .56 (1946), Cnd. 6987, 
This treaty provision follows the 1938 Agency Tax Convention, so does the 1946 UK treaty with the United States, for example. ${ }^{66}$

From 1948 onwards until the early 1960s, the Agency PE provision was written differently from the Agency PE provisions of the early 1940s. This new provision first occurred in the treaty with the Netherlands. Article II $(1)(\mathrm{k})$ of the UK-Netherlands double taxation convention reads:

"The term 'permanent establishment' when used in respect to an enterprise of one of the territories, means a branch, management, factory, or other fixed place of business, but does not include an agency unless the agent has, and habitually exercises, a general authority to negotiate and conclude contracts on behalf of such enterprise or has a stock of merchandise from which he regularly fills orders on its behalf. In this connection:

(i) An enterprise of one of the territories shall not be deemed to have a permanent establishment in the other territory merely because it carries on business dealings in that other territory through a bona fide broker or general commission agent acting in the ordinary course of his business as such;

(ii) The fact that an enterprise of one of the territories maintain in the other territory a fixed place of business exclusively for the purchase of goods or merchandise shall not of itself constitute that fixed place of business a permanent establishment of the enterprise," 67

The 1948 change is only a textual change, not a change concerning the import of the Agency PE concept. More examples of this new text can be found in the double taxation conventions with Sweden (1949), Denmark (1950) and Norway $(1951)^{68}$

66 Article 2 (1)(1). Treaty Series No.26 (1946), Cmd. 6902.

67 Convention between His Majesty in respect of the United Kingdom of Great Britain and Northern Ireland and Her Majesty the Queen of the Netherlands in respect of the Kingdom of the Netherlands for the Avoidance of Double Taxation and the Prevention of Fiscal Evasion with respect to Taxes on Income, London, 15th October, 1948, Treaty Series No. 43 (1950), Cund. 8015.

68 DTC UK - Sweden, 30th March 1949, Treaty Series No. 63 (1949), Cmd. 7800; dtc UK Denmark, 27 th March 1950, Treaty Series No. 47 (1950), Cmd. 8023; dtc UK - Norway, 2nd May 1951 , Treaty Series No. 85 (1951). 


\subsubsection{Treaty Policy from 1960}

The UK followed the 1963 OECD Model Agency PE provision, and so introduced the phrase which referred to the agent "acting in the name of" the principal. In the double taxation convention with Japan (1962), the OECD Model was already being adhered to. ${ }^{69}$ The UK also followed the 1977 OECD Model. ${ }^{70}$ A slight textual change, with regards to the OECD Model, can be found in the 1985 convention with Russia. Article 5 (3) reads:

"Notwithstanding the provisions of paragraph (1) of this Article, where a resident of a Contracting State carries on commercial activities in the other Contracting State through an agent who:

(a) is not an agent of an independent status to whom paragraph (4) of this Article applies;

(b) acts in the interest and on behalf of that resident; and

(c) has and habitually exercises an authority to conclude contracts in the name of that resident;

that resident shall be deemed to have a permanent establishment in the other State..."71

This was obviously a unique change because all later treaties copied the OECD Model provision. ${ }^{72}$

England deviated from the OECD Model in the mid 90s. The phrase 'in the name of' was removed. Article 5, paragraph5, of the treaty with Mexico stated:

"Notwithstanding the provisions of paragraphs (1) and (2) of this Article, where a person - other than an agent of an independent status to whom paragraph (7) of this Article applies - is acting on behalf of an enterprise and has, and habitually exercises, in a Contracting State an

69 DTC UK - Japan, September 4 1962, Treaty Series No.44 (1963), Cmnd. 2064; also ditc UK Germany, 26 November 1964, Treaty Series No. 17 (1967), Cmnd. 3249; dtc UK - Canada, 6 December 1965, Treaty Series No. 18 (1966), Cmnd. 3033.

70 For example the dtc UK - Poland, 6 December 1976, Treaty Series No. 36 (1978), Cmnd. 7170; dtc UK - Hungary, 28 November 1977, Treaty Series No. 82 (1978), Cmnd. 7325; dtc UK - China, 26 July 1984, Treaty Series No. 7 (1985), Cmnd. 9439.

71 Convention between the Government of the United Kingdom of Great Britain and Northern Ireland and the Government of the Union of Soviet Socialist Republics for the Avoidance of Double Taxation with respect to Taxes on Income and Capital Gains, London, 31 July 1985, Treaty Series No.49 (1986), Cmnd. 9881.

72. For example the dtc UK - Belgium, I June 1987, Treaty Series No.25 (1990), Cm 1037. 
authority to conclude contracts on behalf of the enterprise, that enterprise

shall be deemed to have a permanent establishment in that State..."73

This deviation from the OECD Model can be explained in the light of the common law concept of the law of Agency. According to common law, the agent actually contracting 'in the name of' the principal is a relatively unimportant factor and is certainly not decisive. A common law agent binds his principal when acting as an agent. Althoagh the OECD recognised this different agency concept and altered the OECD Commentaries in March 1994 accordingly, they did not change the actual treaty provision. The UK apparently did not want to wait until the OECD changed the model provision.

\subsection{SUMMARY AND CONCLUSIONS}

The UK basis for the Agency PE taxation was laid down in the 1842 Income Tax Act. A foreign principal was taxed on his UK profits made through his UK agent if:

(1) the sale contract was made in the UK, and

(2) the agent received the profits or gains of these transactions.

The actual text of the 1842 provision indicates that in the UK the agent was looked upon as a person who was responsible for the business of the foreign principal. Consequently, it could be concluded that the replacement theory was the leading principle behind Agency PE taxation. This conclusion is also supported by the fact that the law authorised the agent to pay the taxes directly from the profits of his transactions on behalf of his foreign principal.

The Finance Act 1915 played a very important role in the Agency PE. development. The new section 31 of the Finance Act 1915 was introduced, primarily, as anti-avoidance legislation. During the parliamentary debates, three cases were introduced which were the basis for the new legislation. All three cases showed ways to avoid UK taxation of the non-resident principal. Section

73 Convention between the Government of the United Kingdom and Northerr Ireland and the Government of the United Mexican States for the Avoidance of Double Taxation and the Prevention of Fiscal Evasion with Respect to Taxes on Income and Capital Gains, Mexico City, 2 June 1994, Treaty Series No.83 (1995), Cm 2993. 
31 (3) named three conditions justifying application of the anti-avoidance provisions, namely:

(1) the close connection between non-resident principal and resident agent;

(2) the non-resident must have substantial control over the UK agent, and

(3) the domestic business leads to no profits or less than might be expected.

In this act, the taxable base of non-residents was extended, with regards to the 1842 legislation, if the agency relationship met the three conditions mentioned above. Taxation of the non-resident, through the UK agent, was allowed. Two further extensions of the taxable base were introduced. In other words, it was not necessary to tax the non-resident through his UK agent if the profits or gains of the business of the non-resident were actually received by the UK agent. Further, the foreign entrepreneur was also liable to UK taxation if he worked through a UK branch or manager. The taxable base was limited if the nonresident conducted his UK business through a domestic broker, general commission agent or an agent who was not authorised to carry out the regular agency of the non-resident. The 'double foreigner exemption' was also introduced. If a UK agent acted as a middleman between two foreign entrepreneurs, UK taxes were not imposed. The provision exempting brokers, general commission agents and other 'non-authorised' agents was the first of its kind. The League of Nations and OECD later copied it.

Following parliamentary debates at the introduction of this exemption provision, the broker or general commission agent who worked for only one principal were no longer eligible for this provision. A 'general' commission agent was a commission agent who worked for clients generally and who did not in substance confine his activities to one principal, or even an insignificant number of principals (Fleming v. London Produce Co. Ltd.). This shows that current case law, which considers the general commission agent ${ }^{74}$ to be an independent agent and thus eligible for the Agency PE exemption provision, like for example article 5(6) of the OECD Model, is contradictory to the historical meaning of the provision.

The Finance Act 1925 further developed this exemption provision. Roughly, there were three conditions for application of the exemption provision for the

74 For example, the subsidiary company who acts as a civil law commissionair on behalf of their foreign parent company. 
broker or general commission agent: the agent must act 'in the ordinary course of his business as such"; the agent must genuinely conduct the business of a broker or commission agent, and finally he must receive a normal remuneration. The first condition is still an important part of the Agency PE provision of Article 5 (6) of the OECD Model. The League of Nations' 1927 Draft Convention copied the other conditions. It was confirmed that the agent who acted exclusively for the particular non-resident principal remained liable for the income tax of that principal.

An important landmark in the Agency PE development is the UK-Norwegian Agency Tax Convention of 1938. In this convention, an Agency PE provision was made that could be considered to be a basic Agency PE provision which served as a model for later treaties. The provision was based upon the 1915 and 1925 Finance Act.

UK double taxation conventions followed the OECD Model pretty accurately. In the mid-90s, however, the UK altered their Agency PE provision; they omitted the condition that the agent must conclude contracts "in the name of' the enterprise. 


\section{The Agency PE according to United States Tax Law}

\subsection{INTRODUCTION}

In this chapter I will analyse the United States' tax view on the Agency PE concept. First the domestic regulations will be analysed and then the Agency PE provisions in US double taxation conventions. Also, relevant case law will be discussed.

The domestic regulations concerning the Agency PE concept can be found in the general concept concerning the taxation of foreign individuals and corporations. These regulations deal with foreign tax liability. This concept is also known as the "trade or business concept". The US system of taxing foreign individuals or corporations differs from other jurisdictions as a permanent establishment is not the basis for taxation of business income. ${ }^{1}$ The PE concept, however, is analogous but not identical to that of being engaged in a US trade or business and in general would seem to require a greater physical attachment to the United States, not necessarily more activity. ${ }^{2}$

The first part of this chapter deals with the tax liability of foreign individuals and/or corporations. References are made to US domestic tax provisions. These federal tax laws are enacted by US Congress and are contained in the Internal Revenue Code (IRC). Income Tax Regulations (Treas. Regs.) are issued by the Treasury Department, and represent the federal government's interpretation of the IRC. The US tax authorities, the IRS, issues, among other things", "revenue rulings" which provide additional interpretation and clarification to taxpayers.

1 J.C. Amico, Introduction to the U.S. Income Tax System (Kluwer, Deventer, 1993), p. 203.

2 Richard E. Madigan, Taxation of the Shipping Industry, 2nd ed., (Cornell Maritime Press, Maryland, 1982), p. 93.

3 E.g., revenue procedures, private letter rulings, notices and technical advice memoranda. 
5.2

\section{U.S. TAXATION OF FOREIGN INDIVIDUALS AND} CORPORATIONS

There are three basic concepts involved: (1) the nature and source of the taxpayer's income; (2) the taxpayer's activities in the US, i.e. whether he is engaged in US trade or business; and (3) the relation between his income and his US activities, i.e. whether his income is "effectively connected" with a US trade or business. It is within the framework of these three variables that the pattern of US taxation is established. ${ }^{4}$

\section{Scheme: US TAXATION OF FOREIGN CORPORATIONS}

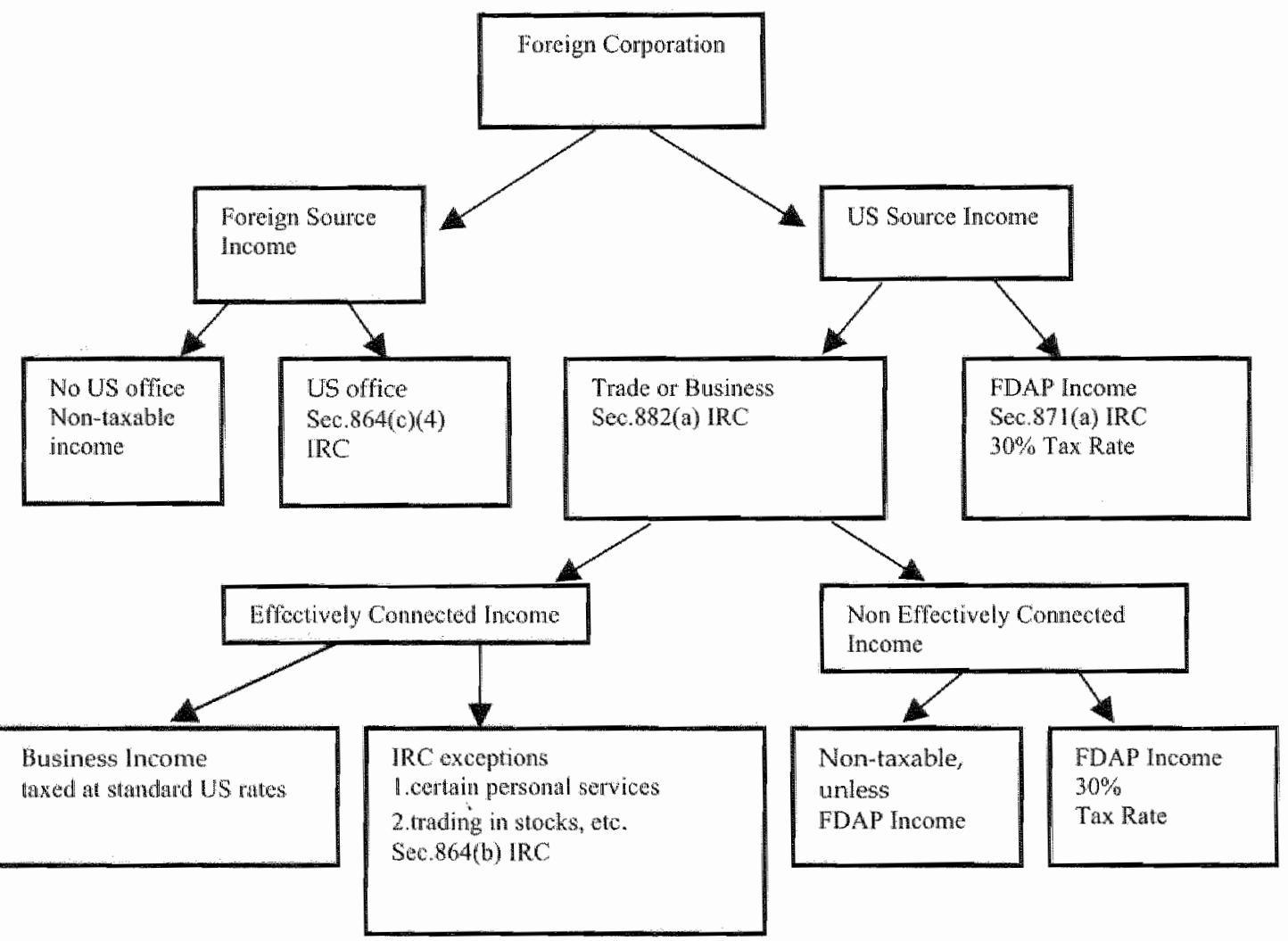

4 P. R. McDaniel \& H. J. Ault, Introduction to United States International Taxation, 3d rev, ed., (Kluwer, Deventer/Boston, 1989), p. 53 . 
In chapter 1, sub-chapter $\mathrm{N}$, the IRC deals with taxes based on income from sources within or outside the United States. Income derived from these sources within the US constitutes "US source income". This income is, according to the IRC, among other interests, dividends, personal services (including labour), rentals and royalties. Sec. 862 IRC describes income from sources outside the United States, or "foreign source income". Non-resident aliens and foreign corporations are taxed only on US source income. ${ }^{5}$ There is an exception to this rule for certain foreign source income eamed through a US office, which will be discussed in the next paragraph. In general, a taxpayer is not taxable on US source income from business operations unless the taxpayer is engaged in a trade or business within the United States.

Part II of chapter 1 contains two different subparts which deal with the taxation of non-resident alien individuals (Sub-part A, \$ 871-879) and foreign corporations (Sub-part B, $\$ 881-885$ ). In light of this study, it's appropriate to analyse the taxation of non-resident foreign corporations. A company is a foreign company if its place of incorporation is outside the US. The place of effective management is not relevant in determining whether a foreign corporation is "within" the US." U.S. OFFICE

\subsubsection{Introduction}

There is one exception to the rule that a foreign taxpayer's foreign source income is not taxable under US code, namely if the foreign taxpayer has an office or other "fixed place of business" within the US and the foreign source income is "attributed" to that office. ${ }^{7}$ If these US office requirements are met, this particular foreign source income is considered to be income effectively connected to US trade or business and will therefore be taxed accordingly.

Sec. $864(\mathrm{c})(4)$ IRC lists four categories of foreign source income earned through a US office which are classified as effectively connected income:

5 Jbid., p. 39.

6 J.C. Amico, op cit., n. 1, p. 8.

7 B.I. Bitker \& L. Lokken, Fundamentals of International Taxation, 2nd ed, Warren, Gorham \& Lamont, Boston/New York, 1991), 66.3.4. 
(1) certain rents, royalties, and capital gains or losses derived from the active conduct of a business of licensing or leasing foreign patents

(2) certain dividends and interest and gain and losses from the sale or exchange of stock or debt instruments that are derived by a foreign taxpayer engaged in the active conduct of banking or financing.

(3) certain foreign source income derived from the sale of inventory property.

(4) the foreign source income of a foreign insurance company attributable to the company's US business.

\subsubsection{The U.S. Agent and Office Requirements}

The agent's activities are taken into account in order to determine if a foreign person has an office or other fixed place of business in the United States. If so, foreign source income may be attributable. Sec. 864(c)(5)(A) stipulates:

"In determining whether a non-resident alien individual or a foreign corporation has an office or other fixed place of business, an office or other fixed place of business shall be disregarded unless such agent (i) has the authority to negotiate and conclude contracts in the name of the nonresident alien individual or foreign corporation and regularly exercises that authority or has a stock of merchandise from which he regularly fills orders on behalf of such individual or foreign corporation, and (ii) is not a general commission agent, broker, or other agent of independent status acting in the ordinary course of his business,"

If a non-resident alien or foreign corporation maintains an office in the US and staffs the office with employees who have neither authority to conclude contracts nor a stock of goods, the office is a US office of the taxpayer, not because an agent's office is attributed to the taxpayer but because the taxpayer maintains the office directly. ${ }^{8}$ The resemblance between the US and OECD Model Agency PE provision is not accidental. The legislative history of the provision states that the agency concept embodied therein is substantially similar to the permanent establishment concept present in many existing US income tax treaties.

8 Treas.Regs $81.864-7(\mathrm{e})$

9 E. Madole, 'Agents as permanent establishments under U.S. incone tax treaties', Tax Management Intemational Journal, June 10, 1994. 
The quoted provision demonstrates, according to Roberts, the extensive reliance on the terminology of the 1963 OECD Model. While the 1963 OECD Model served as the model for the definition of "office or other fixed place of business" in $\$ 864(\mathrm{c})(5)$, nothing in the extensive legislative history of the Foreign Investors Tax Act of 1966 indicates that the Act incorporates the civil law concept of direct representation. ${ }^{10}$ This view seems logical when considering what this provision actually says. A foreign corporation has an office or fixed place of business in the US if his agent concludes contracts in the name of the foreign corporation. In this case the office of the agent shall be treated as the office of the foreign corporation. "This indeed does not primarily indicate a legal interpretation of the phrase "authority to conclude contracts in the name of'. It seems to have a more practical and/or commercial dimension. Regarding the determination of the authority to conclude contracts Treas. Reg. $\$ .1 .864-7$ (d)(1)(ii) states:

"This determination shall be made on the basis of the facts and circumstances in each case, taking into account the nature of the business of the principal; but, in all cases, the frequency and continuity tests are to be applied conjunctively... An agent shall not be considered regularly to negotiate and conclude contracts on behalf of his foreign principal if the agent's authority to negotiate and conclude contracts is limited only to unusual cases or such authority must be separately secured by the agent from his principal with respect to each transaction effected."

The agent of IRC sec. 864(c)(5)(A)(i) is referred to in the Regullations as a dependent agent. An agent, as that term is understood at common law, is subject to a high degree of control by the principal. It is this control, rather than the terms used to describe that relationship, that permits the activities of an agent to be regarded as emanating from the principal. ${ }^{13}$ Isenbergh emphasises the control that a principal has on its agent, therefore describing a "dependent" agent. The agent's authority must have some regularity or rather substance and meaning. If the agent must obtain the proper authority to act in the name of the principal

10 S.I. Roberts, "The Agency Element of Permanent Estabiishment: The OECD Commentaries fiom the Civil Law View (Part Two)", Intertax 1993/10, p. 504.

11 Treas.Reg. $\$ 1.864-7(\mathrm{~d})(1)$.

12 All Treasury Regulations quotes are taken from Intemational Income Taxation, Code and Regullations Selected Sections, 1996-1997 edition, (CCH, Chicago, 1996).

13 J. Usenbergh, The "Trade or Business" Of Foreign Taxpayers In The United States, Taxes, December 1983, p. 982 . 
regarding each individual transaction, it cannot be said that the agent has the required level of authority according to sec. $864(\mathrm{c})(5)(\mathrm{A}) \mathrm{IRC}$.

\subsubsection{Independent Agent}

Treas. Reg. \& 1.864-7(d)(3) gives a definition of an independent agent:

"...the term "independent agent" means a general commission agent, broker, or other agent of an independent status acting in the ordinary course of his business in that capacity."

This text complies fully with standard treaty language (for example, in Art. 5, para. 6, OECD model). However, in the case of the dependent agent:

"the office or other fixed place of business of an independent agent... shall not be treated as the office or other fixed place of business of his principal irrespective of whether such agent has authority to negotiate and conclude contracts in the name of his principal, and regularly exercises that authority, or maintains a stock of goods from which he regularly fills orders on behalf of his principal."14

This indicates that an independent agent who concludes contracts in the name of his principal can still be an independent agent.

Treas. Reg. \$1.864-7(d)(3) gives an example of an independent agent, showing that the way he conducts his business makes him an independent agent, not the authority given by the principal:

"Thus, for example, an agent who, in pursuance of his usual trade or business, and for compensation, sells goods or merchandise consigned or entrusted to his possession, management, and control for that purpose by or for the owner of such goods or merchandise is an independent agent." 


\subsubsection{Exclusive Agent}

The independent agent who acts (almost) exclusively for one non-resident principal risks being no longer regarded as an independent agent. Treas. Reg. $\$$ 1.864-7(d)(3)(iii) stipulates that in such a case:

"...the facts and circumstances of a particular case shall be taken into account in determining whether the agent, while acting in that capacity, may be classified as an independent agent."

This issue was addressed in Handfield $v$. Commissioner ${ }^{15}$, which will be discussed in more detail in para. 5.5.5. The exclusive US distributor of postal cards manufactured by Canadian resident Handfield was an independent company (American News Company Inc.). However, the court ruled:

"From all the provisions of the contract and all the information on the operations of the petitioner in relation to it that are in this record, we think that the arrangement between the petitioner and the News Company was one in which the News Company was his agent in the United States."

The outcome was that Handfield was considered to be engaged in US trade or business and was therefore taxed on US profits.

\section{U.S. SOURCE INCOME}

\subsubsection{Introduction}

After analysing the US tax treatment regarding foreign corporations who earn foreign source income, the next step is to analyse US domestic taxation on foreign corporations who earn US source income. If a particular item of income is deemed to originate or is deemed to be generated from the US, it's called US source income. Under the code, foreign corporations are taxable on two categories of US source income: (1) taxable income effectively connected to a US trade or business; and (2) several types of non-business income from US sources. 


\subsubsection{Non-Business U.S. Source Income}

Income not effectively connected with a US trade or business is exempt from US tax unless it is from sources within the United States and falls within certain designated classes, which include dividends, interests, rents and royalties but not capital gains and other income earned on sales of property. ${ }^{16}$ IRC sec. 871 (a) provides that an amount received by a foreign person or corporation is subject to a flat 30 percent withholding tax if five conditions are met:

(1) The amount received is periodical income;

(2) The amount received constitutes gross income of the taxpayer;

(3) The periodical income is derived from US sources;

(4) The gross income is not effectively connected with a US trade or business;

(5) The gross income is not exempt from the 30-percent tax under some provisions of the code. ${ }^{17}$

This type of income is generally known as FDAP income which stands for fixed, determinable, annual or periodic income from US sources. These sources of income will be taxed, according to Sec. 881 (a), at a 30 percent rate applied to the gross amount of the income, without any deductions or personal exemptions.

\subsubsection{U.S. Trade or Business Concept}

Sec. $882(\mathrm{a})(1-2)$ reads:

"Imposition of tax-

(1) In general. -A foreign corporation engaged in trade or business within the United States during the taxable year shall be taxable as provided is section $11,55,59 \mathrm{a}$, or 1201 (a) on its taxable income which is effectively connected with the conduct of a trade or business within the United States.

(2) Determination of taxable income. -In determining taxable income for purposes of paragraph (1), gross income includes only gross income

16 B.I. Bittker \& L. Lokken, Fundamentals of International Taxation, 2nd ed. (Warren, Gorham \& Lamont, Boston/New York, 1991), p. 66-3.

17 Exemptions for amounts included in the gross income of foreigners apply to two broad categories of interest: income-bank deposit interest and portfolio interest- and to certain other, namowly defined, categories of interest income. Michael I. McIntyre, The International Income Tax Rules of the United States (Michie Law Publishers, Charlottesville, 1992), p. 2-36. 
which is effectively connected with the conduct of a trade or business within the United States." 18

The term "trade or business within the United States" is not defined in the IRC or the Treasury Regulations. As applied to foreign persons, a US trade or business will be found to exist if there are regular, continuous and considerable business activities in the United States. Isolated or sporadic transactions will not usually be construed as the conduct of a trade or business. The classic example of a trade or business are situations in which the taxpayer is engaged in the marketing of goods and services. ${ }^{19}$

In general, whether a foreign corporation is engaged in a trade or business is a question of fact dependent upon the nature and extent of its economic activities. A foreign taxpayer who is engaged in a US trade or business has achieved a substantial level of economic penetration in the US. He is not merely a passive investor but has become a direct participant in the economic life of the country. ${ }^{20}$

\subsubsection{Effectively Connected Income}

If a non-resident foreign corporation has derived US source income and that corporation is engaged in a trade or business in the US, then the actual tax treatment depends on whether the income is effectively connected with the conduct of a trade or business in the US. ${ }^{21}$

Generally, income arising from a US business is clearly effectively connected to US business income. But the US uses a limited forcemof-attraction rule to include as US business income some US source investment income. ${ }^{22}$ This is based on sec. 864(c)(3) which reads:

"OTHER INCOME FROM SOURCES WITHIN UNITED STATES-All income, gain, or loss from sources within the United States (other than income, gain, or loss to which paragraph (2) applies) shall be treated as effectively connected with the conduct of a trade or business within the United States."

18 IRC quotations are from Internal Revenue Code, Income Taxes $\$ \$ 1-999,1996$, Volume 1, (CCH Incorporated, Chicago, 1996).

19 H. Gustafson, J. Peroni \& R. Crawford Pugh, Taxation of International Transactions (West Publishing Co., St. Paul, Minn., 1992), 3010.

20 P.R. McDaniel \& H.J. Ault, op cit., n. 4, p. 53.

21 Ibid., p. 57.

22 J. C. Amico, op cit, n. 1, p. 205. 
In determining whether periodical income is effectively connected with a US business, two factors are considered, based upon sec. 864(2) IRC: (1) whether the income is derived from assets used in, or held for use in, the conduct of a US business; and (2) whether the activities of the US business were a material factor in the realisation of the income.

This narrow grouping of income is not very much considered as effectively connected unless it is attributable to an office or other fixed place of business of the foreign person located in the United States. ${ }^{23}$ If a foreign corporation (or, for that matter, a foreign person) carries on a trade or business in the United States, US tax is imposed on all taxable income that is effectively connected with the trade or business. This taxable income is computed under the same rules that apply to US corporations (or persons), except that gross income not effectively connected with the US trade or business is excluded and deductions are limited to those that are connected with effectively connected income. ${ }^{24}$ Certain periodical income (discussed in para. 5.5.2) not effectively connected to a US trade or business is taxed against a 30 -percent flat rate at the source.

Prior to the enactment of the Foreign Investors Tax Act of 1966, a foreign corporation that was engaged in trade or business in the US was subject to taxation under the force-of-attraction principle, meaning that all income from US sources was subject to taxation. One of the principal changes in 1966 was the rejection of the force-of-attraction principle in favour of the effectively connected concept. ${ }^{25}$ According to Roberts, a principal change was to adopt the concept of a permanent establishment (denominated "fixed place of business" in the Internal Revenue Code as the nexus for taxing foreign taxpayers on business income. ${ }^{26}$ The "fixed place of business" (FPB) concept, referred to by Roberts, is laid down in sec. 864(c)(5) IRC. A section which only applies to foreign source income. The adoption of the PE concept in the IRC by means of the FPB clearly connects to treaty application. Certain foreign source income is treated as effectively connected income if the foreign corporation has a fixed place of business in the US. Because of the US FPB, when applying double taxation conventions, taxation is assigned to the US.

23 E. Madole, 'Agents as permanent establishments under U.S. income tax treaties', Tax Management International Joumal, June 10, 1994.

24 Ibid. Borris L. Bittker \& Lawrence Lokken.

25 J.E. Bishel \& R. Feinschreiber, Fundamentals of Intemational Taxation, 2nd ed. (Practising Law Institute, New York, 1985), p. 214.

26 Sydney Roberts, Intertax 1993/10, p. 504. 
Congress intended the FPB concept to be similar to that of a PE in bilateral income tax treaties. ${ }^{27}$ Thus, precedents illuminating the idea of a PE may be relevant for Code FPB purposes, and, conversely, the regulations interpreting the FPB language may cast some light on the scope of PE clauses in US treaties $^{28}$, nevertheless only relevant concerning foreign source income.

\subsubsection{Foreign Corporation receiving U.S. Source Income through a U.S. Agent}

A corporation as opposed to a natural person, can only act through agents and employees and can only be deemed to be engaged in a trade or business in the United States through the activities of its employees or agents who are performing services on behalf of corporations. ${ }^{29}$ The assessment that a foreign corporation is engaged in a US trade or business does not automatically mean that the foreign corporation has a permanent establishment in the US Treas. Reg. para. 1.864-2(e) states:

"Whether or not such a person (i.e. a foreign taxpayer) is engaged in trade or business within the United States shall be determined on the basis of the facts and circumstances in each case."

This conclusion can be drawn from deAmodio v. Commissioner ${ }^{30}$ In this case a Swiss non-resident alien purchased real estate in the United States and managed it through real estate agents was found to be engaged in a US trade or business, but was not considered to have a PE in the US. The local real estate agents acting on behalf of deAmodio collected the rent, paid taxes and insurance, and arranged for leases on the properties. On the basis of the US- Swiss double taxation convention, the real estate agents were considered to be independent agents acting in the normal course of their business.

In Pinchot v. Commissioner ${ }^{31}$ a British citizen and non-resident owned real estate in the city of New York. Pinchot, a US resident, managed the properties

27 S.REP.No. 1707, 89h Congress, 2d Session 20, reprinted at 1966-2 C.B. 1055, 1072 (1966).

28 Harvey P. Dale, 'Effectively Connected Income', Tax Law Review, vol 42, 1987, p. 734.

29 I. Sarafoponlos, Foreign corporations/U.S. Income Taxation, Tax Management Foreign Income Portfolios, 1988 Tax Management Inc., p. A-46.

30 deAmodio v. Commissioner, 34 T.C. 894,299 E.2d 623 (3d Cir. 1962).

31 US Circuit Court of Appeals for the 2nd Circuit, July 17, 1940, 113 F. (2d) 718, US Tax Cases it 9592. 
under broad powers of attomey which also included the management of certain personal property of the British subject and her two brothers. He bought and sold property for the co-owners under his discretion without consulting the nonresident. The Court of Appeals reasoned:

"The management of real estate on such a scale for income producing purposes required regular and continuous activity of the kind which is commonly concerned with the employment of labour; the purchase of materials; the making of contracts; and many other things which come within the definition of business in Flint v. Stone Tracy Co., 220 U.S. 107, and within the commonly accepted meaning of that word... It is held that the decedent was engaged in business in this country..."

Three elements can be recognised in the quotation cited above, namely that the activities are (1) substantial ("...on such a scale"); (2) regullar and (3) continuous. Interesting is that the Court of Appeals looks at the total activities which are necessary for maintaining the US real estate. The activities of the agent and the principal are bundled together.

In Herbert v. Commissioner ${ }^{32}$ a non-resident was determines to not be engaged in a trade or business. The non-resident owned some US real estate rented to one tenant who was responsible for its operation and repairs. The non-resident's sole activities in connection with this property, other than receiving rents, consisted of paying taxes, insurance, and interest on a mortgage.

The Investor's' Mortgage Security Company Ltd. v. Commissioner ${ }^{33}$ again dealt with a non-resident who had real estate in several states in the US. The properties were operated by agents or attorneys-in-fact ${ }^{34}$ who were located in several states. They were engaged in business as real estate, insurance, and loans, brokers, and financial agents. Most of the properties were rented under leases executed in the name of the non-resident by its atiomey-in-fact. The court concluded that the non-resident was engaged in a US trade or business concerning the real estate activities. In the Memorandum Opinion, Judge Sternhagen points to the fact that all of the US real estate was operated by agents under the control and supervision of the non-resident, therefore leading

3230 Tax Court of United States Reports (1958).

334 TCM 45, 1945, CCH Dec. 14,333 (M).

34 An attomey-in-fact is an agent or representative authorized by his principal, by virtue of a power of attomey, to act for her in certain matters; \$.G. Handler, Ballentine's Law Dictionary (Delmar, Albany N.Y, 1994). 
to the conclusion that the non-resident was conducting business in the US. This ruling is interesting if one compares it with the current Agency PE definition. The agents concluded contracts in the name of the non-resident, which under the current Agency PE concept would lead to tax liability for the non-resident. In Revenue Ruling 55-182 $2^{35}$ the carrying out of transactions in stocks through a resident broker or commission agent did not lead to US taxation. This ruling also complies with the Agency PE concept. This rule was later codified in the IRC, and this provision will be analysed in the next paragraphs.

In Handfield $v$. Commissioner ${ }^{36}$ the court had to determine if Handfield, a Canadian manufacturer of postal cards, was engaged in US trade or business. Handfield had an agreement with a US news company giving the latter exclusive distribution rights of Canadian postal cards in the United States. The court determined that they had "an extremely meagre record" on which to decide if Handfield was engaged in trade or business. The court resolved their problem by answering the question by means of the PE definition in the USCanada treaty. ${ }^{37}$ Because the US news company, under its contract with Handfield, had a stock of merchandise from which it regularly filled orders for the public, they qualified the company under the treaty as being the agent of Handfield. Because Handfield was considered to have a PE in the US under the treaty, this subsequently meant that he was engaged in business within the US.

In Revenue Ruling 76-322 $2^{38}$, the IRS ruled that a US subsidiary of a foreign corporation can be an independent agent. They stated:

"The subsidiary corporation"s presence in the country concerned, where it is engaged in trade or business, is by itself no basis to hold that the parent corporation has a $\mathrm{PE}$ in such country, unless the subsidiary has and habitually exercises a general authority to contract for its parent, or as an agent of the parent regularly fills orders of goods on behalf of the parent from a stock of the parent's goods located in such country.,39

35 Revenue Ruling 55-182, 1955-1 C.B. 77.

3623 Tax Court of United States Reports 633 (1955).

37 The article provides that an agency shall be regarded as a PE if the agent has, and habitually exercises in that State a general. authority to negotiate and conclude contracts on behalf of the enterprise.

38 Rev.Rull. 76-322, 1976-2 C.B. 487.

39 Rev.Rul. 76-322, at 488. 
This possibility was already offered by a 1949 court ruling in National Carbide Corporation versus Commissioner. ${ }^{40}$ In this case a parent corporation claimed that its subsidiaries were employed as its agents to manage and operate manufacturing plants, as well as to sell the output of the plants, and therefore, that all of the income of the subsidiaries was attributable to the parent. The Supreme Court rejected the parent's claim, but indicated that is was possible for an entity to be a "true corporate agent under some circumstances." is that the court summed up several factors which could help the correct assessment of a true agency:

"Whether the corporation operates in the name and for the account of the principal, binds the principal by its actions, transmits money received to the principal and whether receipt of income is attributable to the services of employees of the principal and to assets belonging to the principal... If the corporation is a true agent, its relations with its principal must not be dependent upon the fact that it is owned by the principal, if such is the case. Its business purpose must be the carrying on of the normal duties of an agent. ${ }^{.42}$

\subsubsection{IRC Exemption Provisions}

Section 864(b) attempts to define the term "engaged in a trade or business" but really does little more than set out two general exceptions: (1) performance of personal services for certain employers, if the person spends no more than 90 days in the US and earns no more than $\$ 3,000$; and (2) trading in stocks, securities, and commodities through independent parties or for one's own account. ${ }^{43}$ The specific provisions regarding the performance of personal services do not contain rules regarding the treatment of permanent representatives or agents. The specific provisions regarding the treatment of trading in stocks, securities or commodities do contain certain rules regarding agents. ${ }^{44}$

4069 S. Ct. 726, 37 AFTR 834 (1949).

41 H.J. Levin \& A.J. Littman, "Contracting Out, Not Branching Out: Manufacturing Revisited", Tax Management Intemational, 1993, p. 351 .

$4269 \mathrm{~S}$. Ct. at 734 .

43 R.L. Kaplan, "Federal Taxation of Intemational Transactions - principles, planning and policy", Anerican Casebook Series (West Publishing Co., St. Paul, 1998), p. 541.

44 H.D. Rosenbloom, D.K. Sutherland, \& D.M. Ring, Taxation of permanent establishments - The United States, (IBFD, Amsterdam, 1994), p. 36. 


\subsubsection{Trading in Stocks, Securities or Commodities}

The trade or business within the United States does not include, according to sec. $864($ b) $(2)(A-C)$ IRC:

"TRADING IN SECURITIES OR COMMODITIES.-

(A) STOCKS AND SECURITIES.-

(i)IN GENERAL.-Trading in stocks or securities through a resident broker, commission agent, custodian, or other independent agent.

(ii) TRADING FOR TAXPAYER'S OWN ACCOUNT.-Trading in stocks or securities for the taxpayer's own account, whether by the taxpayer or his employees or through a resident broker, commission agent, custodian, or other agent, and whether or not any such employee or agent has discretionary authority to make decisions in effecting the transactions. This clause shall not apply in the case of a dealer in stocks or securities, or in the case of a corporation (...) the principal business of which is trading in stocks or securities for its own account, if its principal office is in the United States.

(B) COMMODITIES.-

(i) IN GENERAL.-Trading in commodities through a resident broker, commission agent, custodian, or other independent agent.

(ii) TRADING FOR TAXPAYER'S OWN ACCOUNT.- Trading in commodities for the taxpayer's own account, whether by the taxpayer or his employees or through a resident broker, commission agent, custodian, or other agent, and whether or not any such employee or agent has discretionary authority to make decisions in effecting the transactions. This clause shall not apply in the case of a dealer in commodities.

(iii) LIMITATION.- Clause (i) and (ii) shall apply only if the commodities are of a kind customary dealt in on an organised commodity exchange and if the transaction is of a kind customarily consummated at such place.

(C) LIMITATION.- Subparagraphs (A)(i) and (B)(i) shall apply only if; at no time during the taxable year, the taxpayer has an office or other fixed place of business in the United States through which or by the direction of which the transactions in stocks or securities, or in commodities, as the case may be, are effected."

Trading "through a resident broker, commission agent, custodian, or other independent agent" is not a trade or business if the taxpayer does not have an 
office in the United States. The foregoing rule applies to brokers and dealers in securities and commodities, as wel $\|$ as to casual investors, and the volume of the taxpayer's securities and commodities transactions in the United States is irrelevant to its application. ${ }^{45}$

The exemption does not apply in the case of a "dealer in stocks". A dealer in stocks is a merchant of stocks and securities ${ }^{46}$, with an established place of business, regularly engaged as a merchant in purchasing stocks or securities and selling them to customers with a goal of gains and profits that may be derived. Persons who buy and sell, or hold stocks or securities for investment or speculation are not considered to be dealers in stocks or securities within the meaning of this provision. ${ }^{47}$

The commodities exemption only applies when the following conditions are met: (i) the commodities are of a kind customarily dealt in on an organised commodity exchange, such as grain futures or the cotton futures market, (ii) the transaction is of a kind customarily consummated at such place, and (iii) the taxpayer at no time during the taxable year has an office or other fixed place of business in the United. States through which, or by the direction of which, the transactions in commodities are affected. ${ }^{48}$ The term "commodities" does not include goods or merchandise in the ordinary channels of commerce. ${ }^{49}$

The term "discretionary authority", according to sec. $864(\mathrm{~b})(2)(\mathrm{A})(\mathrm{ii}) \mathbb{R} \mathrm{RC}$, needs some elaboration. A daily pattern of instructions to sell or buy within a reasonable price range and to adjust hedge positions to reflect these transactions may well go beyond the statutory safe harbour and constitute a US trade or business. To limit this risk of doing business, the US broker would have to operate within very narrow trading limits provided by the foreign dealer. ${ }^{50}$

According to the history of sec. $864(\mathrm{~b})(2)(\mathrm{A}-\mathrm{C})$ IRC, which goes back to the Revenue Act of 1936, the word "commission agent" comprises a person similar

\footnotetext{
45 Bitter \& Lokken, $\mid 66.3 .2$.

46 The term "securities" means any note, bond, debenture or other evidence of indebtness, or any evidence of an interest in or right to subseribe to or purchase any of the foregoing, according to Treas. Reg. $1.864+2(\mathrm{c})(2)(\mathrm{c})$.

47 Treas.Reg $\$ 1.864-2(\mathrm{c})(2)(\mathrm{iw})$.

48 Treas Reg $1.864-2$ (d)(1).

49 Treas.Reg. $1.864-2$ (d)(3).

50 L.B. Samuels \& P.A. Brown, "Observations on the Taxation of Global Securities Trading", Tax Law Review, 1990/45, p. 550.
} 
to a broker who makes transactions in commodities for the public in general, as distinguished from an ordinary agent who receives his compensation on the basis of a percentage of the merchandise sold. The idea of exclusiveness enters into an employment of agency. An agent often works exclusively for one principal, while a broker generally holds himself out for employment in matters of trade and commerce. ${ }^{51}$ The US agent with discretionary powers is a regular agent who would be taxed on behalf of his foreign principal by means of sec. $864(\mathrm{c})(5)(\mathrm{A})$ IRC. This explains the condition of the lack of discretionary powers of the US trader in stocks and securities who acts on behalf of a foreign trader and wants to qualify for the safe harbour rule. A brokerage status alone, for example, is not enough for qualifying under this rule, a factual assessment of the activities of the broker is essential.

\subsubsection{U.S. Partnerships}

\subsubsection{IRC Rules}

Sec. 875(1) IRC rules that:

"a non-resident alien individual or foreign corporation shall be considered as being engaged in a trade or business within the United States if the partnership of which such individual or corporation is a member is so engaged,..."

The imputation from a general partnership would probably arise in the absence of any statutory provision because of the common law notion that a partnership is a mutual and collective agency relationship. ${ }^{52}$ In a general partnership each partner functions as an agent of every other partner, while in a limited partnership the limited partners are viewed as having appointed the general partners as their agents. ${ }^{53}$ The tests for determining whether a partnership is engaged in a US trade or business are those applicable to foreign persons generally, as discussed in the previous paragraphs. Basically, under US tax law, a non-resident partner may be taxable on:

51 D.M. Garelik, "What Constitutes Doing Business Within the United States by a Non-Resident. Alien Individual or a Foreign Corporation', Tax Law Review, 1963/18, p. 431.

52 J. Isenbergh, "The "Trade or Business" of Foreign Taxpayers in the United States", Taxeswhe Tax Magazine, December 1983, p. 982.

53 E.W. Madole, 'Agents as Permanent Establishments under U.S. Income Tax Treaties', Tax Management Intemational Journal, June 1994. 
(1) income which is effectively connected with the conduct of a trade or business within the US, and

(2) FDAP income. ${ }^{54}$

The principal effect of sec. 875 (1) IRC is that the partner's distributive share of the partnership's income effectively connected with the US business is subjected to income tax in the partner's hand. The converse issue- whether a partnership is engaged in a US business by virtue of a partner's activities-- depends upon whether the partner is acting as an agent for the firm or on his own behalf. ${ }^{55}$

\subsubsection{U.S. Case Law}

A constant challenge for international tax practitioners- concerning the IRS- is to reconcile the principle of the Code (IRC) with their analogues under tax treaties to which the US is a party. ${ }^{56}$ There are two US tax court decisions which specifically deal with the question if a US partner or partnership can create tax liability in the US for a foreign partner. In the Donroy case $e^{57}$ it was decided that limited partners have a PE in the country where the partnership has its office or other PE-constituting premises. A California-based limited partnership had a business in beverages and other products, dealing in real property and the transportation business. Donroy was a Canadian resident who was a limited partner in the US partnership. The court reasoned the following:

"each partner, whether general or limited, has an interest as such in the assets and the profits of the partnership, including the physical plant or offices at which the partnership conducts its business, so that the office or PE of the partnership is, in law, the office of each partnerwhether limited or general".58

In the Unger case ${ }^{5 y}$ the same issue as in the Donroy case was under evaluation: did a Canadian limited partner have a PE because of his participation in a US limited partnership? The same considerations as in Donroy were stipulated: the

54 A.H.M. Daniels, Issues in Internationall Partnership Taxation, (Kluwer, Deventer, 1991), p. 73.

55 Bittker \& Lokken, $\$ 66.3 .2$.

56 R.E. Andersen, "Permanent Establishments" for partmers under treaties fround from (somewhat) analogues code provisions", The Journal of International Taxation, May/June 1992, p. 62.

57 Donroy Ltod. versus United States, 196 F. Supp 54 (N.D.Cal.1961), affd, 301 F.2d 200 (9th Cir. 1962).

58 lbid.

59 Robert Unger, 190,015 PH Memo TC. 
limited partner owned undivided interest in assets of the US partnership and therefore owned interest in a partnership's PE (offices, etc.). The court stated:

"Because the actual taxation of a partnership is achieved through the aggregate theory of partnership, we hold the aggregate theory of partnership to be also applicable when determining whether a partner has a 'permanent establishment' in the United States within the meaning of the Convention."

In Revenue Ruling $91-32^{61}$ the IRS held that a foreign partner is taxable on its sale of an interest in a partnership engaged in a US trade or business through a fixed place of business, as though there had been a sale of the underlying partnership assets allocated to the selling partner. This is a view which also adheres to the aggregation theory. The US tax liability for a non-resident partner of a US partnership all depends on the question if the US partnership has a US trade or business. If this is the case, the US trade or business is imputed to the foreign partner. If no US trade or business is present, the US source income will be defined as FDAP income. If a non-resident partner receives US source income from his participation in a US partnership which does not engage in a US trade or business, the income will be classified as FDAP income and will therefore be taxed against a flat 30 percent rate.

\subsection{DOUBLE TAXATION CONVENTIONS}

The US has concluded numerous bilateral taxation conventions. A basis for its treaty negotiations is the US Model Income Tax Convention, which was modified in 1996 (from hereon referred to as the US Model 1996).

Art. 7 (1)US Model 1996 reads:

"The business profits of an enterprise of a Contracting state shall be taxable only in that State unless the enterprise carries on business in the other Contracting State through a permanent establishment situated therein. If the enterprise carries on business as aforesaid, the business profits of the enterprise may be taxed in the other State but only so much of them as are attributable to that permanent establishment."

60 The U.S.-Canadian treaty was applicable.

61 Revenue Ruling 91-32, 1991-1. CB 109. 
According to this article a foreign taxpayer will not be taxed on business income from sources within the US unless that income is attributable to a permanent establishment located in the US. In general, a PE may take the form of an office, or other fixed place of business, or an agent of the taxpayer with authority to enter into contractual relationships or who fills orders from a stock of goods located in the agent's country. Beyond these two general principles, many treaties enumerate in detail the types of activities which will or will not constitute a permanent establishment. ${ }^{62}$

US treaties commonly say that a PE exists if an enterprise works through an agent in the treaty country and if that agent has the authority to bind the parent organisation. Such authority is the agent's ability to make contracts for the enterprise if (1) the authority is regularly used and (2) the contracts cover more than just the agent's purchases of goods for the enterprise. ${ }^{63}$

Before looking into the various forms in which Agency PE provisions appear in US treaties, the US Model 1996 will discussed.

\section{7}

\section{THE U.S. MODEL INCOME TAX CONVENTION 1996}

Art. 5 (5) and (6) of the US Model 1996 contain the Agency PE provisions:

"5. Notwithstanding the provisions of paragraphs 1 and 2, where a person-- other than an agent of an independent status to whom paragraph 6 applies- is acting on behalf of an enterprise and has and habitually exercises in a Contracting State an authority to conclude contracts that are binding on the enterprise, that enterprise shall be deemed to have a permanent establishment in that State in respect of any activities that the person undertakes for the enterprise, unless the activities of such person are limited to those mentioned in paragraph 4 that, if exercised through a fixed place of business, would not make this fixed place of business a permanent establishment under the provisions of that paragraph.

6. An enterprise shall not be deemed to have a permanent establishment in a Contracting State merely because it carries on business in that State through a broker, general commission agent, or any other

62 P.R. McDantel \& Hugh J. Ault, op cit., n. 4, p. 180.

63 R.M. Sommerfeld, H.M. Anderson, H.R. Brock et al., An Introduction to Taxation Advanced "Topics, 2nd ed., (Harcourt Brace Jowanovich, New York, 1982), p. 21/11. 
agent of an independent status, provided that such persons are acting in the ordinary course of their business as independent agents."

If one compares this provision to Art. 5 of the OECD Model, it is obvious that the United States omitted the OECD Agency condition, namely that the agent must have the authority to conclude contracts in the name of the enterprise. ${ }^{64}$

The Technical Explanation on the US Model 1996 explains the omission as follows:

"The OECD Model uses the term "in the name of that enterprise" rather than 'binding on the enterprise'. This difference is intended to be a clarification rather than a substantive difference. As indicated in paragraph 32 to the OECD Commentaries on article 5, paragraph 5 of the Article is intended to encompass persons who have "sufficient authority to bind the enterprise's participation in the business activity in the State concerned"."

The writers of the US Model 1996 state that the omission of the phrase "acting in the name of" is merely for the sake of clarification. It's no substantive difference compared to the Agency PE provision of the OECD Model. Its interesting to observe that the previous US Model of 1981 did contain an Agency PE provision which was completely in line with the OECD Model provision. ${ }^{65}$ According to Nitikman the thrust of the US Model 1981 Agency PE provision is that the agent must be able to bind the principal in contract. ${ }^{66}$

In the next paragraph I will analyse if indeed there is no substantive difference between the Agency PE provision in the US Model 1996 and the OECD Model.

64 A Pleijsier, "The Agency Permanent Establishment Under Revision?: "Acting in the nane of", or "what"s in a name?" ", Intertax 1997, Volume 257, Issue 6-7, p. 253.

65 Art. 5. para. 5, US Model 1981 reads: "... Where a person... is acting on behalf of an enterprise and has and habitually exercises in a Contracting State an authority to conclude contracts in the name of the enterprise, that enterprise shall be deemed to have a permanent establishment in that State..."

66 J. Nitikman, "The Meaning of "Permanent Establishment" in the 1981 U.S. Model Income Tax Treaty: Part 2", The International Tax Journal, 1989, p. 261. 

MODEL

The omission of the phrase "in the name of" is in my view an important change of the Agency PE definition. The US seems to adhere to Sidney Roberts' view, as he outlined in 1993. ${ }^{67}$ According to Roberts:

"The OECD Treaties incorporate the civil law nontax concept of direct and indirect representation. Direct representation refers to contracts concluded in the name of the foreign enterprise, which means that under the internal nontax law that is applicable to the contract the principal and the third party are liable on the contract. 168

The omission of the phrase "in the name of" in the US Model 1996 is in my view in line with the domestic "trade or business" concept. The commercial activities of the foreign principal who acts through a resident agent are being assessed on a factual and commercial basis. This is, according to Treasury Regulations primarily a factual assessment, not a legal one. Also, because US law is based on common law, the phrase "in the name of" has practically no meaning in US legal practice. The law of agency is based on the agent who has the authority to legally bind his principal. ${ }^{69}$ So on the basis of this conclusion, it seems coherent with domestic tax law that the US doesn't need the phrase "concluding contracts in the name of" in their model Agency PE provision.

\section{9}

\section{AGENCY PE PROVISIONS IN U.S. TREATIES}

Pre-OECD treaties concluded by the US provide that a PE exists if the dependent agent maintains a stock of merchandise from which the agent regularly fills orders on behalf of the non-resident. OECD-type treaties typically do allow for the use of facilities solely for the purpose of storage, display, or delivery of goods and correspondingly allow maintenance of a stock of goods solely for these same purposes. ${ }^{70}$

67 S. Roberts, "The Agency Element of Permanent Establishment: The OECD Commentaries from the Civil Law View (Part One) \& (Part Two)", Intertax 1993/9 \& 1993/10.

68 S.I. Roberts, op cit., n. $67,(1993 / 9)$, p. 399.

69 Or in other words, create legal liability for the principal to the contract concluded by the agent.

70 Tax Treaties, volume 1, 1 1002.7, (Wamen, Gorham \& Lamont, Boston, 1996), p. 1017. 
Many US treaties contain Agency PE provisions similar to the OECD Model. For example, in the US/UK double taxation treaty (1975), according to Art. $5(4)^{71}$, a person acting in one state on behalf of an enterprise of the other state is deemed to be a PE. This is qualified by the requirement that the person: (1) has an authority to conclude contracts in the name of the enterprise; and (2) habitually exercises that authority in the state. ${ }^{72}$ The treaties concluded with Australia, India, Ireland and Switzerland contain a somewhat different Agency PE provision. For example, Art. 5 (4)(a) of the 1982 Australian treaty reads:

"it carries on business in that other State through a person, other than an agent of independent status to whom paragraph 5 applies, who has authority to conclude contracts on behalf of that enterprise and habitually exercises that authority in that other State,..."73

This provision omits the last part of the OECD phrase: concluding contracts "in the name of". Perhaps its no coincidence that this deviation from the OECD provision occurs in treaties with mainly common law countries.

The provision which excludes independent agents, like the broker or general commission agent, from the general Agency PE clause, appears in most US treaties in the exact same way as in the OECD Model. The US treaties with Belgium, China, India and the Philippines contain independent agency provisions which are more extensive than the OECD Model counterpart. Art. 5 (6) of the treaty with Belgium reads:

"A resident of one of the contracting States shall not be deemed to have a permanent establishment in the other Contracting State merely because such resident engages in industrial or commercial activity in that other Contracting State through a broker, general commission agent, or any other agent of an independent status, where such broker or agent is acting in the ordinary course of his business. This paragraph shall not apply if such broker or agent is acting on behalf of an insurance company

71 Art. 5 (4) of the convention of December 31, 1975 between the United States and the United Kingdom, America-Dutch Tax Series, main volume, January 1995 edition, (New Amsterdam Law Books, Amsterdam, 1995).

72 A review on U.S. treaties can be found in I. S. Phillips, Tax Treaty Networks, (Worldwide Information Inc, Chur, 1988).

73 This text is taken from Doemberg/van Raad's US Tax Treaties, (Kluwer, Deventer, 1991). 
if such broker or agent has, and habitually exercises, an authority to conclude contracts in the name of that company.",

The last phrase is typical Belgian treaty language. ${ }^{75}$ Belgium is one of the few countries which considers an independent insurance agent or broker to be an Agency PE of the foreign insurance company in which name the agent concludes contracts, like insurance policies.

In the treaty with India, after the standard treaty provision [like Art. 5(6) OECD Model] the following phrase is added in Art. 5 (5):

"However, when the activities of such an agent are devoted wholly or almost wholly on behalf of that enterprise and the transactions between the agent and the enterprise are not made under arm's-length conditions, he shall not be considered an agent of independent status within the meaning of this paragraph."

This phrase, more or less, can also be found in the US treaties with China and the Philippines.

\subsubsection{The Taisei Case}

In 1995 the US Tax Court ruled in the so-called Taisei case that a US agent didn't create a Agency PE of its Japanese principals. ${ }^{77}$ Four Japanese insurance companies wrote reinsurance through a North Carolina corporation (Fortress Re, Inc.) which conducted its operation in the United States. The US-Japanese Income Tax Treaty contained in Art. 9 (4-5) an Agency PE provision similar to the OECD Model. During the court proceedings it was accepted by both parties (IRS and the Taisei Insurance Company) that Fortress, the US agent, did in fact have- and habitually exercised- the requisite contractual authority to conclude contracts in the name of Japanese insurance companies. The IRS conceded that Fortress had acted in the normal course of its business during the course of its

74 lbid.

$75 \mathrm{Ph}$. Hinnekens, Belasting van niet-imwoners ("Taxation of non-residents"), (Biblio, Kalmthout, 1994), p. 69.

76 Doemberg/van Raad's, op cit, n. 73.

77 Taiset Fire and Marine Insurance Co., Ltd., 104 TC No. 27 (May 2, 1995). 
representation of such companies. Accordingly, the only issue to be decided was whether Fortress was an "agent of an independent status"?

Because the Agency PE provision in the applicable treaty indeed duplicated Art. 5 of the OECD Model, the court justly went to the OECD commentaries for further analysis. Because the treaty with Japan was concluded March 8, 1971, comment 15 to article 5 of the 1963 OECD Model was applicable, which states:

"Persons who may be deemed to be PE's must be strictly limited to those who are dependent, both from the legal and economic points of view, on the enterprise for which they carry on business dealings."

The court agreed with the IRS that either legal or economic dependence determines independence. The taxpayer submitted that an agent is independent unless it is dependent both legally and economically on its principal. ${ }^{79}$

The court stated that Fortress was legally independent of the Japanese insurers. The insurers had no interest in Fortress and no representative of any of the insurance companies was a Fortress director, officer, or employee. The management agreement granted complete discretion to Fortress to conduct the reinsurance business on behalf of the insurers. In that same management agreement, the only limitation that Fortress had to take into account was "net acceptance limit". This is the maximum amount of liability that Fortress was authorised to write on behalf of a company for any one reinsurance contract. Fortress could issue any number of reinsurance contracts as they saw fit, as long as the net acceptance limit was not exceeded in each contract. ${ }^{80}$ The court reasoned:

"...even an independent agent only has authority to perform specific duties for the principal. It is freedom in the manner by which the agent performs such duties that distinguishes him as independent."

78 E.W. Madole, "The Importance of Being Independent: The Taisei Case", Tax Management International, 1995, p. 373.

79 R. S. Schwartz, "Taisei: U.S. Agent Did Not Create Permanent Establishment", The Joumal of Intemational Taxation, July 1995, p. 293.

80 According to the record, the gross acceptance limits were set by Fortress as part of its strategy to limit risk through diversification. Fortress advised petitioners (the Japanese insurance companies) of the gross acceptance limits for informational purposes and changed the limits without the advice or consent of petitioners. Fortress refused to put gross acceptance limits in the management agreements in order to retain flexibility; 104 TC No.27, p. 552 . 
Concerning economic independence, the court determined that Fortress did bear entrepreneurial risk. It was economically independent of the Japanese insurance companies because:

"Fortress access to profitable reinsurance contracts, as well as its experience and ability to choose profitable reinsurance contracts, attracted petitioners to Fortress, and would attract other insurance companies if Fortress needed another client to take a share of the contracts." $" 81$

Finally, the court found the actual profits of Fortress significant: "This is not the kind of sum paid to a subservient company."

The importance of the Taisei case is undisputed. It demonstrates firstly the importance of the OECD commentaries. Since the OECD commentaries are customarily more detailed than even Treasury's explanations of a treaty, the ability to rely on them can significantly help establish an interpretation. ${ }^{82}$ I believe that the Taise case modifies the definition of the independent agent. A principal can most certainly give instructions to his agent. Because it's his business that is being conducted by the agent, the principal can set certain conditions. This does not necessarily mean that the agent would not be considered to be independent. Any agent has overall strategic limits on its authority, and it is freedom to perform normal duties that distinguishes the agent as independent. ${ }^{83}$

In the Taisei case no evidence was found that the Japanese insurance companies directed Fortress' day-to-day operations. Interference with the daily business of the agent would not be tolerated; no independent agent would accept such interference. I do agree with Fink that, given the fact-specific nature of the Taisei Case, more cases outside the insurance area will be necessary to define the term "independent agent" with any precision. ${ }^{84}$

81104 TC No.27, p. 556.

82 B.W. Reynolds \& C. Clinton Stretch, First Tax Court Test of New IRS Approach to Agency Permanent Establishment: Service Loses', Joumal of Taxation, September 1995, p. 173.

83 See in 279.

84 E.H. Fink in US Tax Scene, Intertax 1995/8-9, p.460. 


\subsection{0 .2 InverWorld}

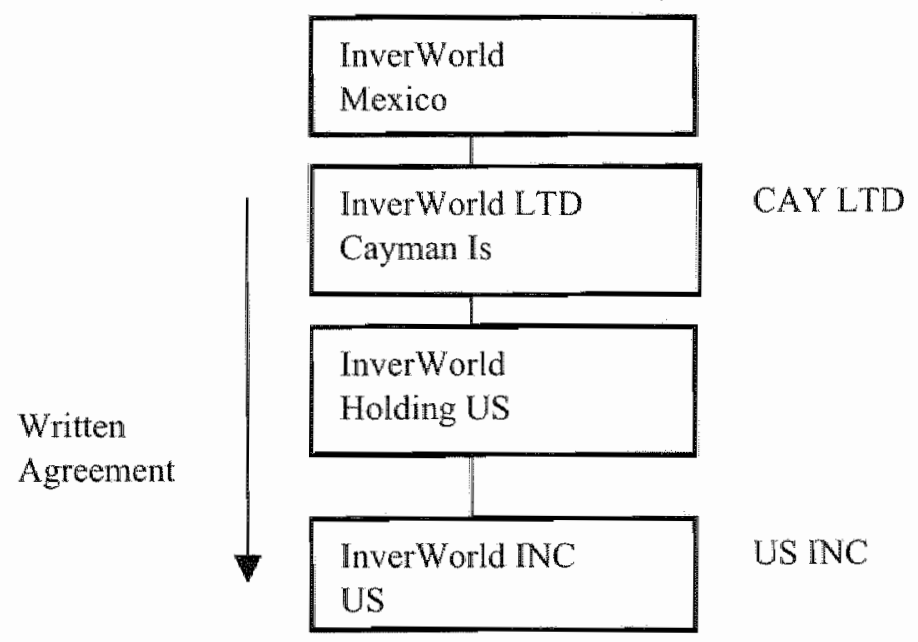

InverWorld, Inc. versus Commissioner ${ }^{85}$, a US Tax Court ruling in June 1996, dealt with numerous tax issues. In light of this study, one of those issues is important, namely the question when and if a foreign corporation can be deemed to be engaged in a US trade or business by means of its US agent. Because of the multiplicity and complexity of the facts in this case I will limit my analysis to the above-mentioned question.

A Cayman Island based company, InverWorld LTD, was an investment management and financial services company, which formed a US company (InverWorld INC). As the illustration on this page shows, the shares of InverWorld INC (from hereon referred to as US INC) were held by InverWorld Holdings, a 100 percent US subsidiary of InverWorld LTD (from hereon referred to as CAY LTD). The Tax Court had to determine whether or not US INC was an agent of CAY LTD. ${ }^{86}$

The written agreement between CAY LTD and US INC gave US INC the power to invest cash, securities and other properties, maintain accounts, books and records on behalf of CAY LTD. The agreement further stated that US INC

85 T.C. Memo 1996-301, Tax Ct Rep. 51,428(M) (CCH), at 3231.

86 For an extensive analysis of the InverWorld case, R.W. Toan, B.L. Gold, P.J. Connors, \& B.L. Patton, "Foreign Broker Was Engaged in US Trade or Business Through the Activities of an Agent: InverWorld, Inc. v. Comr.', Tax Management International Journal, October 1996. 
would for all purposes be an independent contractor and not an agent, and that US INC shall have no authority to act for, represent, bind or obligate CAY LTD. ${ }^{87}$ The court, nevertheless, decided that US INC had "the authority for and in the name of CAY LTD" to carry out the "acts specified in the agreement pursuant to CAY LTD's instructions." Accordingly, the court concluded that US INC had the authority to negotiate and conclude contracts in the name of CAY LTD.

Although in their written agreement CAY LTD and US INC stipulated that US INC would not be an agent of CAY LTD, the court found that US INC was indeed acting as an agent. ${ }^{88}$ However, the written agreement did give US INC the power to invest cash, securities and other properties as CAY LTD might instruct, and the authority to purchase and hold securities and other properties, all on behalf of CAY LTD. The court found that the statement that US INC was not an agent of CAY LTD was contradictory to US INC's authority- for example, to purchase securities and invest cash. The making of such investments on behalf of CAY LTD and on behalf of their clients appears to confirm the ability of US INC to bind CAY LTD to third parties and thus confirm the agency relationship.

The next question was if US INC was an independent agent. The court referred to Treas. Reg. $\$ 1.864-7$ (d)(3)(iii). In that provision it is determined that the independent agent who acts almost exclusively for one non-resident principal risks being no longer regarded as an independent agent. ${ }^{89}$ US INC earned more than 90 percent of its income from CAY LTD. As the court noticed, US INC acted almost exclusively for one principal, namely CAY LTD. The next step in the court's analysis was the application of sec. $864(\mathrm{c})(5)(\mathrm{A})$. On the basis of this provision the office of an agent is attributed to its foreign principal if the agent (1) concludes contracts in the name of the principal and (2) is not a broker, general commission agent or other independent agent. ${ }^{90}$

Because the court already determined that US INC was not an independent agent, the analysis was restricted to the first condition of IRC sec. 864(c)(5)(A), the concluding of contracts "in the name of" the foreign principal. After reviewing the agreement between CAY LTD and US INC the court states that

87 See th 283, p. 656 .

88 As Toan, Gold, Connors \& Patton noticed, this conclusion was drawn by the court as a preliminary matter, virtually without analysis.

89 See para. 5.4.4. of this chapter.

90 See para. 5.4.2. of this chapter for the complete text of this provision. 
US INC had "the authority for and in the name of CAY LTD" to carry out the following:

"acts specified in the agreement pursuant to CAY LTD's instructions, including, inter alia, purchasing, selling and dealing in instruments or evidences of indebtedness by whomsoever issued. US INC alone performed the purchase, sale, and redemption of the instruments and evidences of indebtedness."

The court's final conclusion was that US INC was acting as an agent of CAY LTD; that US INC was conducting significant business activities in the US on behalf of CAY LTD; and that CAY LTD on these grounds was engaged in a US trade or business. The extensive trading activities of US INC on behalf of CAY LTD could be regarded as a brokerage business. Trading through an independent broker is, based on Treas. Reg. $\$ 1.864-7(d)(3)$, exempt from US taxation. In this case the court decided that US INC was not an independent broker because US INC almost acted ( $90 \%$ ) exclusively for CAY LTD.

\subsection{1}

\section{SUMMARY AND CONCLUSIONS}

The US trade or business concept determines whether or not a foreign corporation will be liable to US taxation on its US business activities. The trade or business concept is not based upon the permanent establishment. Sec. 864(c)(5)(A) IRC, part of the trade or business concept, shows striking resemblance with the Agency PE provision of the OECD Model. If a foreign entrepreneur has a US agent who has the authority to negotiate and conclude contracts in the name of his principal and regularly exercises that authority, and cannot be regarded as a general commission agent, broker or other independent agent, the foreign entrepreneur is liable for US domestic taxation- a provision which only applies to foreign source income.

Treas. Reg. $\S 1.864-7(d)(3)$ (iii) contains a special provision which stipulates that the independent agent who acts (almost) exclusively for one non-resident, will carefully be investigated to determine if that agent indeed is an independent agent. In Handfield $v$. Commissioner an unrelated US company (Inc.) was considered to be the agent of a Canadian company, thus creating tax liability for the Canadian company. The assessment of the facts in this case lead to this

91 Toan, Gold, Connors \& Patton, p. 661. 
conclusion: in InverWorld v. Commissioner a quantitative standard was laid down to determine when an independent agent is considered to be acting almost exclusively for one principal, namelly more than $90 \%$.

Because this is the first case in which the court mentions a percentage in this regard, no definite standard can be derived from the InverWorld case. New case law has to show, for example, if a US agent who acts- say $85 \%$ - for one principal is considered by the court to act almost exclusively for one principal. Similar to this line of reasoning is the consideration of the court in the Taise case, namely that the fees the US agent (Fortress) received from the Japanese principal "is not the kind of sum paid to a subservient company".

The US largely depends on the Agency PE provision of the OECD Model in their bilateral tax conventions. However, a major change to that policy came about with the introduction of the US Model convention of 1996. In the Agency PE provision of the US Model 1996 the phrase "in the name of" was left out in the standard Agency PE definition. Although the US authorities state that this omission is intended to be a clarification rather than a substantive difference, I do not share this opinion. As I showed in para. 5.13 this omission is coherent with US domestic tax law. According to Treas. Reg. $\$ 1.864-7$ (d)(1)(ii) the phrase "authority to conclude contracts in the name of" does not have to be judged legally but commercially. The facts and circumstances in each agency relationship shall determine if the foreign principal is liable to US taxation. So in other words, if the US agent generates profits for his foreign principal doing this by selling products or services that the foreign principal manufactures or supplies, then US taxation is in order. The legal basis in this instance is certainly not decisive; the actual activities of the agent are.

The Taisei case proved the importance of the OECD commentaries with interpreting the purport of the Agency PE provision in bilateral tax treaties. Another important conclusion which can be drawn from the Taisei case is that the independent agent can be subjected to some degree of control or instructions by the principal. Any agent has overall strategic limits on its authority but has freedom to perform normal duties that distinguish the agent as independent. The Taisei case also proved that an agent who acts "in the name of" the principal can still be an independent agent and thus not necessarily an Agency PE. 


\section{The Dutch Agency PE Concept}

\section{1}

\section{INTRODUCTION}

As Daniels pointed out, the Agency PE first appeared in Dutch tax law at the introduction of the Besluit Inkomstenbelasting 1941 (Income Tax Act 1941). ${ }^{1}$ In Dutch the phrase Agency PE is translated as vaste vertegenwoordiger, which literally means permanent representative. This Dutch term is based on the German term ständiger Vertreter, which also stands for "permanent representative". Rouwers proved in his dissertation on foreign tax liability rules in the Netherlands that there were some references made to a kind of representative from the 1893 business tax law onwards. ${ }^{2}$

Art. 1 (h) of this 1893 law levied business tax from:

"from others residing abroad, who conducted their business, profession, office, dignity, services or employment in this country personally or by authorised representatives, at least three months in succession, or from others, if it can be concluded, on the basis of agreements or other information, that they conduct the business at least three months consecutively." 3 [See Appendix, Quote 17 for original in Dutch.]

The idea behind this provision was the replacement theory, it would make no difference if a foreign entrepreneur or an authorised person (gevolmachtigde) appointed by the entrepreneur would conduct his business in the Netherlands. This was the same concept as was used in Germany $(\$ 3.2)$.

The word agent (vertegenwoordiger in Dutch) first appeared in the 1914 Income Tax Act. This provision was not different, with respect to the content,

1 A.H.M. Daniels in his annotation on a ruling of Hof $s$-Gravenhage, 25 jun 1986 nr. $576 / 84$ M IT, FED $16-7-1987$, p. 1191.

2 R.W.G. Rouwers, Buitenlandse belastingplicht, (Vermande, Lelystad, 1996), p. 44.

3 Wet van 2 October 1893 tot heffing eener belasting op bedrifs-en andere inkomsten, Staatsblad 1895, No.149, p. 104. 
from the above quoted 1893 business tax law provision. Non-resident persons or companies were liable to Dutch income tax if they, according to Art. 2, conducted the business in the Netherlands themselves, or used an agent who conducted the business for, at least, a three months period. ${ }^{, 4}$

Several developments in this area occurred. The regulation of 15 April 1920, No. 91 (B.2777) interestingly states that persons who have the task of locating potential buyers of products of foreign companies, a task comparable to that of a broker, are not considered to be agents. ${ }^{5}$ If a foreign entrepreneur has a Dutch agent who conducts his business for a period longer than three months, he will be liable to Dutch income tax. The revised income tax act of 1928 , known as the Beshit Inkomstenbelasting 1928, did not alter article 2 of the 1914 Income Tax. Act. A decision of the Hoge Raad (Supreme court) of 13 April 1932 (B.5196) pointed out that a resident wife, who was married without marriage settlements ${ }^{6}$, and had a domestic business, was not an agent of her husband who lived abroad.

The Minister of Finance declared in a 1933 regulation $^{7}$ that if a foreign company only used a Dutch address regarding an advertising campaign, this would not lead to the assumption that the foreigner conducted his business in the Netherlands. If, however, that foreign company sold its products in the Netherlands by means of an agent who had general authority to act and to conclude contracts, the foreign company-apart from the advertising campaignwould be considered to have a Dutch business conducted by its agent. In Hoge Raad 28 October 1936 (B.6228) a foreign entrepreneur (manufacturer of stockings) hired a Dutch agent who worked on a commission basis, assisted by an employee of the non-resident entrepreneur. The agent sold the foreign entrepreneur's goods, sometimes supplying the goods from a stock of goods the agent kept in Holland. The court held that the mere fact that a non-resident entrepreneur used an independent agent who only solicited orders was not sufficient to establish tax liability for the non-resident. The agent in this case took orders from cllients and in some cases, passed them on to the foreign principal. He also wrote all the invoices, monthly accounts and receipts. In this case, however, the court held that the agent's activities went further than merely soliciting orders. The non-resident had a stock of goods in Holland managed by

4 Art.2, Wet op Inkomstembelasting 191.4, Schumrman en Jordens No. 53a, (Tjeenk Willink, Zwolle, 1915), p. 5-6.

5 R.W.G. Rouwers, op cit., n. 2, p. 82.

6 According to Dutch law this means that all the marital assets belong to the man and wife. Both have the same rights.

7 Regulation 8 December 1933 , No. 136, B.5776. 
the agent, the orders were placed and issued in Holland, and finally, the activities were not only done by the agent but also by the employee of the nonresident. The foreign stockings manufacturer was liable to pay Dutch income tax. $^{8}$

An important statement is made by the Hoge Raad in their ruling of 20 November 1940 (B.7250):

"...it can only be determined that an agent conducts the business in the Netherlands for a foreign company, if the person of flesh and blood residing in the Netherlands or the legal entity performs acts, belonging to the business purpose of the foreign company, in the name of, on behalf of, for the account of, and more or less according to the instructions of the foreign company;"[See Appendix, Quote 18 for original in Dutch.]

In this statement a lot of relevant elements of the current Agency PE concept can be found. An agent conducts a domestic business if the resident agent, whether a person or a company, acts (1) in the name of, (2) on behalf of, and more or less (3) according to the instructions of the foreign company, if these acts belong (4) to the core activities (bedrijfsdoel) of the foreign company. This court decision is one of the few, in those days, that mentioned the fact that the agent must conclude contracts in the name of the foreign company.

\section{2}

\section{INCOME TAX ACT 1941}

During the German occupation, the 1914 Income Tax Act was replaced by the Besluit Inkomstenbelasting 1941, based upon the German Einkommenstewergesetz of 1934. This 1941 Income Tax Act contained a separate section which dealt with the tax liability of non-residents. According to art. 39 (1)(b) liable to pay income tax were non-agricultural companies, if conducted by a permanent establishment or permanent representative present in the Netherlands. ${ }^{10}$

8 This was in accordance with the resolution of 4 September 1930, No.80, B.5019. There it was decided that an agent who had a stock of consigned goods and sold goods on behalf of the foreign principal indeed was to be considered to be an agent within the meaning of Art. 2 of the 1914 lncome Tax Act.

9 R.W.G. Rouwers, op cit., n. 2 , p. 107.

10 Beshut op de inkonstenbelasting 1941, De Belastingwetgeving Serie D.B. No. 2, door P. Karmelk, zevende druk, (I.Noorduijn \& Zn., Gorinchem, 1954.), p. $278 \mathrm{e}$. 
This provision codified tax liability for the non-resident who had a nonagricultural enterprise in the Netherlands conducted through a domestic PE or Agency PE (vasten vertegenwoordiger). An Agency PE was considered to be present if there was a subordinate relationship between the foreign entrepreneur and the domestic agent, or if the agent had general power of authority (volmacht) to conclude contracts. The holder of a stock of goods in commission was not- on that single fact allone- deemed to be an Agency PE of the foreign owner of the stock of goods. However, if this fact was combined with other circumstances- like the fact that the foreign entrepreneur gave the agent a compensation for different expenses, e.g. office rent, advertising costs and so forth- this coulld very well lead to an Agency PE. ${ }^{11}$

An important court ruling was Hoge Raad 17 May 1961. ${ }^{12}$ An English insurance association, active in the shipping industry, had a Dutch agent who had full. authority with certain transactions, and a limited authority for other transactions. The double taxation convention between Holland and the UK, contained in Article II $(1)(k)$ a provision which stipulated that a Agency PE was present if the agent had a general authority to conclude contracts. The lower court (gerechtshof) ruled that the Dutch agent had no general authority, because an authority which did not apply to a major category of transactions, could not be regarded as being general. Commentator A.J. van Soest called this view a quantitative interpretation, and he claimed that the Dutch Supreme Court, the Hoge Raad, applied a qualitative interpretation. The Supreme Court ruled that it is adequate for the application of the Agency PE rule of the treaty, if there is a general authority present and this authority is exercised habitually. The court also noted that an authority to conclude contracts of a certain category without the presence of a particular authority to conclude all kinds of contracts, still complies to the term "general authority".

There were two points that the Supreme Court found decisive in this case: (1) the agent concludes contracts in the name of the principal, and (2) the principal was liable to the contract concluded by its agent. The Dutch agent was deemed to constitute an Agency PE of the English insurance association. Van Soest referred to the OEEC report $(\$ 7.6)$ where the commentary mentions the "scope of their agent's authority" and "the nature of their agent's business dealings". These phrases point to a qualitative interpretation of the term "general authority".

11 According to the commentary by P. Karmelk on Art 39 of the Besluit Intomstenbelasting 1941 , see ibid fin. 225 .

12 Hoge Raad, 17 May 1961, Rolno. 14 458, published in BNB 1961/196. 


\section{3}

In 1964 the Dutch Income Tax Act, inkomstenbelasting (IB 1964), was completely revised. In art. $48(4)^{13}$ IB 1964 as business income was considered the amount of all profits which are derived from a business, or part of a business, that is carried on by a permanent establishment or agency PE present within the kingdom (domestic enterprise). This was the only provision in the Income Tax Act 1964 which referred to the Agency $\mathrm{PE}$.

The content of this provision is completely in line with the Income Tax Act of 1941.

This provision basically deals with the allocation of profits of the foreign entrepreneur who has a PE or Agency PE in the Netherlands.

\section{4}

\section{UNILATERAL REGULATION 1965}

In 1965 a new law was introduced in the Netherlands, a law which provided for unilateral relief of double taxation. This law is called the Bes/uit voorkoming dubbele belasting (order for the prevention of double taxation) also in the Netherlands known as the Eenzijdige regeling (unilateral regulation).

This law stipulated in Art. 2(4)(b):

"not an Agency PE is:

1. a completely independent agent;

2. an agent not authorised to conclude transactions, regardless if he keeps a stock of goods for emergency deliveries;"

Art.2(4)(c) added:

" if only goods are held in commission, a permanent establishment or Agency PE is not considered to be present." "It "See Appendix, Quote 19 for original in Dutch.]

An Agency PE is not (1) a completely independent agent; or (2) an agent who isn't authorised to conclude transactions, regardless of the fact that he keeps a stock of goods for rush orders. If an agent merely keeps goods in commission ${ }^{15}$,

13 Originally this provision was numbered as article 48(4); a year later this provision wax renumbered as article $49(1)(a)$.

14 Besluit Voorkoming Dubbele Belasting, 7 April 1965, Staatsblad 145.

15 Meaning that the principal entrusted the goods to the agent. The principal is the legal owner of the goods. 
no Agency PE is present. This refers to the Dutch commissionair who has goods in commission, and on the basis of that fact will not be an Agency PE.

\section{5}

\section{CASE LAW IN THE $1970^{\mathrm{S}}$}

In Hoge Raad 13 January 1971 the question was if an American insurance company had a Dutch Agency PE. ${ }^{16}$ The American company engaged a Dutch insurance broker to sell air travel policies at a counter at Amsterdam airport. The Dutch agent sold the policies in the name of the US company. In the agreement between the US company and the Dutch insurance broker there was no provision which granted the Dutch broker an explicit authority to negotiate on behalf of the US company. In fact, at the counter at the airport there was no substantial negotiating between the counter clerk and the clients. Clients could only choose from two policies. The clerk filled in the forms, cashed the premiums, signed them, and the insurance agreement was concluded. The Hoge Raad (Supreme Court) ruled that the Dutch broker had a general authority, although this authority was not a written one. It was further determined that the concluding of insurance contracts in the name of the insurance company, was not acting in the ordinary course of an insurance broker. Decisive in this issue was the fact that the agent fully acted according to the "Franchise Manual", issued by the insurance company. This manual, in great detail, demanded a certain facial expression, glimpse, voice and choice of words which the agent must use in order to sell the insurance policies. According to the court, this was not the way a true independent insurance broker would normally act.

In Hoge Raad 21 April $1971^{17}$, it was decided that a German company, that owned a block of apartment buildings in the Netherlands, was liable to pay Dutch income tax because they had a Dutch Agency PE. A Dutch broker managed the block of flats. He collected the rents and other payments and could, if necessary, hire an attorney to recover the rent. The broker could order repairs of the building and pay for the repairs. He also paid all of the taxes on behalf of the Germany company. In all of the affairs concerning the management of the building, the broker was authorised to represent the Germany company (even in court). The Hoge Raad held that the broker constituted an Agency PE of the German company. The way in which the broker conducted his business was not the way of a broker who acted in the normal course of his business, but the way of an Agency PE. However, the 
Hoge Raad did recognise the possibility that a broker could do more for his clients than the mere intermediating between two parties.

The Amsterdam court ruled in 1978 that the factual assessment of the activities of a resident agent of a Swiss company, could lead to an Agency PE, although there is no actual written authority of the agent, but a de facto authority. ${ }^{18}$ Besides concluding contracts in the name of the Swiss company, the agent made decisions about decreasing or increasing prices, price-fixing and discounts. The resident agent was, according to the court, an Agency PE of the Swiss company. The Beshit Voorkoming Dubbele Belasting of 1989, altered in 1994, contains the exact same Agency PE provision as in the 1965 version.

6.6 KINGDOM TAX REGULATION

The Netherlands enacted a law (Rijkswet) which deals with the prevention of double taxation between the Netherlands and the Dutch Antilles and Aruba, former Dutch colonies. The 1964 law (BRK) ${ }^{19}$ was concluded between the Netherlands, and Surinam and the Dutch Antilles. In the 1985 law ${ }^{20}$ Surinam was omitted from the BRK and replaced by Aruba. ${ }^{21}$ This law has a provision which deals with the Agency PE, namely article 4.

This provision is practically the same as Art. 5, para. 6, OECD model. While the OECD model, however, mentions "any other agent on an independent status", the BRK refers to "een andere agent met een wezenlijke onafhankelijke positie" [in English "another agent with a essentially independent position"]. The Dutch word "wezenlijk" means something is "of vital importance". The new BRK of 13 December $1996^{22}$ did not alter the Agency PE definition.

\section{7}

\section{CASE LAW IN THE $1980^{\circ}$}

A Swiss company was 100 percent owned by a Dutch resident. The resident concluded business transactions on behalf of the Swiss company. He could, without any limitations, financially bind the company to its clients. The Hague

18 Hof Amsterdan, 20 June 1978, Rolno. 1106/76, BNB 1979/190.

19 Rijkswet, 28 October 1964, Stb. 425.

20 Rijkswet, 5 December $1985, \mathrm{Stb} .645$.

21 The Netherlands and Surinam concluded a double taxation convention on 25 November 1975 , Tractatenblad 1975, nr. 134.

22 KB 13 December 1996 , Stb. 644. 
court found the resident to be an Agency PE of the Swiss company. An important point was that the Dutch resident, as 100 percent shareholder, was the only one involved in the company who had the skills and technical knowledge concerning the specific activities of the company (air-conditioning and refrigeration). ${ }^{23}$

In BNB $1986 / 100^{24}$, a case known as the Baggerarrest (the dredger case), a Dutch dredger did a project, in partnership with other companies, in Liberia. The main problem in this case was the allocation of profits. For the actual duration of the project the dredger appointed a supervisor in Liberia. The supervisor had an authority to represent the dredger. The case did not mention what the actual powers of the supervisor were. The Hoge Raad, without clearly explaining why, ruled that the appointment of an authorised supervisor for the duration of a project abroad, is not sufficient for the assessment of the supervisor as an Agency PE. If the supervisor would primarily supervise the project, it could not be determined that the supervisor concluded contracts regarding the core activities of the Dutch dredger. The contracts the supervisor would possibly conclude, would in my view be contracts of a preparatory and/or auxiliary character. The ruling of the Hoge Raad is therefore a correct one.

\subsection{DOUBLE TAXATION CONVENTIONS}

After the 1914 Income Tax Act, the Netherlands ratified four tax treaties: with Belgium (1933), Sweden (1935), the United Kingdom (1935) and Hungary $(1938)^{25}$

In para. 3 of the treaty with Belgium ${ }^{26}$ the PE is described as follows:

"As permanent establishments are considered seats of the actual management, branches, factories, workshops, agencies, warehouses, offices, laboratories, purchasing and salesoffices, storage depots, as well as other permanent establishments of a productive nature. The fact that an enterprise, established in one of the states, maintains business relations

23 Hor"s-Gravenhage, 28 March 1983, Rolno. 101/82 MII), BNB 1984/279.

24 Hoge Radd, 23 Janwary 1974, Rolno. 17237), BNB 1986/100.

25 R.W.G. Rouwers, op cit «, n. 2, p. 81.

26 Verdrag tusschen Nederland en België ter voorkoming van dubbele belasting en tot regeling van eenige andere belastingaangelegenheden, 20 februari 1933, Staatsblad 1935, S.214, p. 298. 
with the other state through mediation of a truly independent company (broker, commissionair, subsidiary company...etc.), does not mean that that company has a permanent establishment in that state.,27?

[See appendix, quote 20 for the original in Dutch.]

The starting point of this provision is the permanent establishment. The text sums up the different ones, like the factory, office, warehouse, etc. Interesting is that this summary contains "agentschappen", Dutch for agencies. The last sentence of this provision resembles the current Agency PE exclusion provision. If a foreign company has business relations in the Netherlands through a truly independent company, this does not mean that the foreign company has a Dutch PE. Between brackets examples are given of this truly independent company, namely the broker, commission agent and subsidiary company.

In the 1935 treaty with the UK the term "vertegenwoordiger" (agent) is used in the main text and defined in art. 1(b) as an agent who has a general authority to negotiate and conclude contracts, and exercises this authority habitually. ${ }^{28}$

In the 1950 s the Agency PE provision was slightly modified and expanded. An example can be found in the treaty with Denmark of 20 February $1957 .{ }^{29}$ Article 2 (1)(f) reads:

"This expression does not contain agencies, unless the agent has a general authority to negotiate contracts and concludes those contracts in the name of the enterprise which he represents, en exercises this authority habitually, or has a stock of goods from which he regularly delivers ordered goods in the name of the enterprise.' [See Appendix, Quote 21 for the original in Dutch.]

In comparison to the 1935 treaty text with the UK, this provision adds that the agent must conclude contracts "in the name of" of the foreign company. It further adds that an Agency PE is also the agent who has a stock of goods from which he fills orders. The treaty further stated if a foreign entrepreneur has

27 The same provision is contained in the 1935 treaty with Sweden (S.282) and in the 1938 treaty with Hungary (Handelingen der Staten-Generaal, Bijlagen 1938-1939). In the treaty with Hungary, however, the term "vaste vertegenwoordigingen" (Agency PE) is added to the text.

28 The text of the treaty can be found in Handelingen der Staten-Generaal, Bijlagen 1934-1935, 472.1.

29 Tractatenblad 1957 , nr.52. 
business relations in the Netherlands by means of a bona fide broker or general commission agent, acting in the normal course of his business, this single fact doesn't mean that the foreign company has a PE in the Netherlands. ${ }^{30}$

Treaties concluded in the 1960s and later closely follow the OECD model. The Netherlands adheres to the OECD model concerning the Agency PE provision. The Agency PE provision in the Dutch model treaty of $1987^{31}$ is an exact copy of the OECD model.

\subsection{SHIP BROKER CASE}

One of the most important court rulings on the Agency PE is, without a doubt, the Cargadoorsarrest (ship broker case). ${ }^{32}$ A Dutch cargadoor, or shipping broker, represented about sixteen different shipping companies. The Dutch tax authorities wanted to $\operatorname{tax} X$ Ltd., a shipping company from Singapore, that was represented in the Netherlands by the Dutch shipping broker. X Ltd. offered a container service between the Far East and some European ports. The services of the shipping broker were incorporated in the "Port Agency Agreement", a standard contract used by the shipping broker, and they performed standard services. ${ }^{33}$ Although the shipping broker had many duties, the Hoge Raad found that the instructions to X Ltd. were not very detailed and comprehensive, and the shipping broker had no freedom to perform those very duties.

The shipping broker mainly acted in his own name, meaning that most contracts were not concluded in the name of the principal. Only in the case of cargo booking the shipping broker acted in the name of X Ltd. The Hoge Raad (Supreme Court) determined that the shipping broker was an independent agent of X Ltd. The Hoge Raad noticed that it could be possible that an agent who performs several duties for his principal, could be regarded as an Agency PE for certain duties, while for the other activities the agent would be considered to act as an independent agent. The Dutch Supreme Court did not agree with the standpoint of the The Hague tax court (Gerechtshof) which stipulated that the shipping broker should be regarded as an Agency PE concerning all contracts

30 Art. 2 ( 1 )(f)(i) of the Dutch -- Danish dtc of 20 February 1957, op cit., n.29.

31 Nederlands Standaand Verdrag 1987.

32 Hoge Racd, 15 June 1988, Rolno. 24 881, BNB 1988/258.

33 The cargadoor took care of, for example, the economic management (husbandry), custom services, payment of port charges, supply of fuel, etc, arrange for repairs and dry docking, cargo booking, advertising campaigns, arrange for stevedoring (loading and/or unloading of ships), control and superwise movement by $X \mathbb{L} t d$. owned or leased equipment, prepared and processed container documents, delivery of inward cargoes, etc. 
he concluded in the name of his principal. The Supreme Court referred to the Dutch broker who can, according to Art. 62 of the Dutch Commercial Code ${ }^{34}$, conclude contracts in the name of the principal, but still is explicitly named in the Agency PE exemption provision (e.g., Art. 5 (6) OECD Model).

Van Brunschot stated that, on the basis of the OECD model, (i) an independent agent can't be an Agency PE provided that he acted in the normal course of his business, (ii) the broker, who concluded contracts in the name of his principal, is mentioned explicitly as an independent agent, and therefore (iii) it can't be said that the agent who concludes contracts in the name of his principal cannot be independent. ${ }^{35}$ Also Van Raad draws this conclusion from the Cargadoorsarrest: an agent who acts on behalf of, and in the name of a foreign entrepreneur, does not on these grounds disqualify himself as an independent agent. $^{36}$

In this ruling the Hoge Raad implicitly rejected Roberts' view on the Agency $P E$, namely that if an agent concludes contracts in the name of the principal, he absolutely can't be recognised as an independent agent within the scope of Art. 5, para. 6, OECD model. ${ }^{37}$ Another important conclusion from this case is that the Hoge Raad looks at the group of independent agents (e.g., brokers or general commission agents) when considering the phrase "acting in the ordinary course of their business" of Art. 5, para. 6, OECD model. ${ }^{38}$ The Cargadoorsarrest had a sequel in 1995 (BNB 1996/108c). In the next paragraph this important ruling will be discussed.

\subsection{THE DUTCH INSURANCE AGENT CASE}

In the ruling of the Hoge Raad of 28 June $1995^{39}$, the facts were as follows: a UK property insurance company (X PLC) employed a Dutch agent. This Dutch agent (C BV) represented several different insurance companies. Dutch law knows two types of insurance agents, namely the legal representative and the authorised agent. These are two kinds of agents who are by law authorised to

34 See paragraph 2.4.2.

35 See BNB 1988/258, p.1668-1669.

36 K. wan Raad, De vaste vertegenwoordiging en de bepaling van de daarmee behalde winst, Gielebundel, (Kluwer, Deventer, 1990), p. 520 .

37 P.G.H. Abent, Vaste inriching, (FED, Deventer, 1994), p.70.

38. E.A. Brood \& E. Boomsluiter, Vaste vertegenwoordiger of onofhankeliyke ondernemer?, WFR $1994 / 6090$, p. 203.

39 Hoge Raad, 28 June 1995, Rolno. 29 435, BNB 1996/108c. 
act on behalf of a property insurance company. ${ }^{40}$ Legal representative in this case meant that X PLC was supposed to be established at the office of C BV and that according to the law $\mathrm{C} B V$ has, with regards to the conducting of the property insurance business, the same powers as X PLC. When C BV acted as an authorised agent, this would mean that C BV acted in the name of X PLC. It (C BV) signed insurance policies and arranged damaged procedures. The question in this procedure, obviously, was if $\mathrm{C} \mathrm{BV}$ was an Agency PE of X PLC.

The Chancellor of the Exchequer (staatssecretaris van Financiën) argued that $\mathrm{C}$ BV acted in two capacities, or, as he called it, with two hats on. One hat is that of the truly independent agent (in this case when acting as the legal representative) and the other that of the dependent agent acting in the name of the principal. The Hoge Raad didn't agree with this viewpoint. The Hoge Raad reasoned that this view of the Chancellor of the Exchequer would mean that, although $\mathrm{C} \mathrm{BV}$ on the whole would be regarded as an independent agent ${ }^{41}$, with regards to the application of the treaty, the activities of $C B V$ must be split in two parts. One part of the activities of C BV, on behalf of X PLC, must be regarded as belonging to the enterprise of X PLC, whereas the other activities belong to the enterprise of $\mathrm{C} \mathrm{BV}$ as an independent insurance agent.

This view is, according to the Hoge Raad, not correct. The Hoge Raad refers to the treaty and the OECD model, and stipulates that there's no basis for the view that if an entrepreneur, as an agent of a foreign company, concludes a contract, the entrepreneur was supposed to be acting partially dependent and partially independent from the one he represents. The Hoge Raad doesn't say, in my view, that it is not possible that an agent could be regarded as acting as an independent agent towards one client, and as an dependent agent in relation to another client. In other words, the relationship between the agent and the client or principal must be analysed separately from the relationships with other clients. This is a pure and correct methodology, because the Agency PE is the concept by which a foreign entrepreneur can be taxed by the state where the agent is conducting the business. The Agency PE question must be answered in determining to what extent the foreign entrepreneur, as an individual person or company, is active in the agent's state.

40 Based upon the Wet op het schadeverzelevingsbedriff (law regarding the property insurance companies). This law contains conditions to which foreign insurance companies must adhere, if they want to engage in the Dutch property insurance business.

41 This fact was not contended by the Chancellor of the Exchequer during the appeal. 
Van $\mathrm{Raad}^{42}$ states that it is also possible, based on BNB $1996 / 108 \mathrm{c}$, that one kind of transaction on behalf of a principal does create tax liability in the Netherlands, while the other kind of activities do not create tax liability. So Van Raad even recognises the possibility that with regard to one principal an assessment could be made that two different activities lead to two different conclusions: on the one hand possible tax liability for the principal (the agent deemed to be an Agency PE), and on the other hand no tax liability on the basis of the other activities. This view agrees with my above-mentioned conclusions about this ruling. The Hoge Raad does not approve that one kind of activities of the agent on behalf of the foreign principal (where in general the agent is regarded to act as an independent agent) as a whole could be split into one or more parts which must be regarded as activities of an dependent agent, thus creating tax liability for the foreign principal.

\subsection{SUMMARY}

The historical development of the Dutch Agency PE concept strongly resembles the German Agency PE concept. The first Agency PE-like provision was found in the 1893 business tax law. The idea behind this provision was the replacement theory, it would make no difference if the foreign entrepreneur or his Dutch authorised agent would conduct business in the Netherlands. The 1914 Income Tax Act followed on those same lines. The Besluit Inkomstenbelasting 194I was the first tax law which mentioned the Agency PE (vaste vertegenwoordiger). The Dutch Income Tax Act, from 1964 on, does not contain a definition of the Agency PE. A law which provides unilateral relief of double taxation (Beshit voorkoming dubbele belasting) contains a provision which shows in which case there's no Agency PE. Dutch treaty policy narrowly follows the OECD Model.

There are two Dutch court rulings which provide important material concerning the Agency PE concept. In the Cargadoorsarrest, the Hoge Raad rejected Sidney Roberts' view on the independent agent, namely that if an agent concludes contracts in the name of the principal he can never be recognised as an independent agent within the scope of Art. 5, para. 6, OECD model. The Hoge Raad takes an objective standpoint when considering the phrase "acting in the normal course of their business". The most important conclusion of the Cargadoorsarrest was that the Hoge Raad assumed that it could be possible

42 C. van Raad in his anmotation on BNB 1996/108c. 
that an agent who performs certain duties for his principal, could be regarded as an Agency PE for certain duties, while for the other activities the agent would be considered to act as an independent agent. This line of reasoning was the subject of a court ruling some years later. In Hoge Raad 28 June 1995 (BNB 1996/108c) the Hoge Raad didn't approve that the activities of an independent agent could be split into independent agency activities (not leading to tax liability for the foreign principal) and dependent agency activities leading to tax liability for the foreign principal. 


\section{CHAPTER 7 \\ The League of Nations \& OECD}

\section{1}

INTRODUCTION

In the previous chapters of this study I've analysed the Agency PE concept in Germany, the United Kingdom, the United States and the Netherlands. The next important step in the development of the Agency PE concept is the work of the League of Nations (LON). The LON, founded in 1919, had as its main objective the promotion of international co-operation, peace and security. Through disarmament, peaceful settling of conflicts and to guarantee sovereignty and independence of its member states, the LON tried to reach its goals." The sovereignty of a state also includes fiscal sovereignty. With that in mind, the Financial Committee of the LON appointed in 1921 a committee of four economists. They had to investigate the economic consequences of double taxation, as a basis for further study on this area. The committee published their final report in April 1923. ${ }^{2}$

In the 1920s, during the London conference of the International Chamber of Commerce (ICC), from June 27 to July 1, 1921, the selected committee of the Chamber presented their report on double taxation. The ICC committee formulated principles conceming the legal claim of a country to tax citizens and foreigners. ${ }^{3}$ In the following year, at the end of 1922, the Financial Committee of the LON appointed a committee of tax experts "to examine from an administrative and practical point of view both the problem of double taxation and that of tax evasion". This committee was known as the committee of technical experts. The Financial Committee considered that "in order to arrive at any real solution of the two important questions, it was essential to obtain the opinion of the representatives of certain Governments."

1 M. N. Shaw, Imernational Law, 3rd ed, (Grotius Publications, Cambridge, 1991). p. 747.

2 The four mentioned economists were Bruins of Rotterdam, Einaudi of Turin, Seligman of Columbia University and Stamp of the University of London. The repont was called 'Report of Double Taxation', LON, Document E.F.S. 73/F.19, Geneva April 5, 1923.

3 International Chamber of Commerce, brochure no. 11, Double Taxation, Paris 1921. 
This committee consisted of representatives from Belgium, former Czechoslovakia, France, Great Britain, Italy, the Netherlands and Switzerland, and their final report was issued on February 7, 1925. After this report's publication, the committee of technical experts was expanded to include representatives from Argentina, Germany, Japan, Poland and the United States. This committee of twelve met three times in plenary sessions between May 1926 and April 1927. They produced four drafts of conventions, namely a convention for the prevention of double taxation, a convention for the prevention of double taxation in the special matter of succession duties, a convention on administrative assistance in matters on taxation and finally a convention on judicial assistance in the collection of taxes. ${ }^{5}$

In October 1928 a plenary session was held and the report on double taxation of the commintee of technical experts was discussed by the fiscal representatives of the Member States. ${ }^{6}$ The aforementioned plenary session resulted in the founding of a Fiscal Committee. The main objective of the Fiscal Committee was the prevention of double taxation by drafting model treaties, the preparation of conferences and the study of tax-related problems of international law. The Fiscal Committee assembled a number of times in $1929 .{ }^{8}$

\section{THE AGENCY PE ACCORDING TO THE LEAGUE OF NATIONS (1921-1929)}

\subsubsection{The 1927 League of Nations Draft Convention}

The first mentioning of the agent as a permanent establishment by the LON can be found in the Draft Convention for the Prevention of Double Taxation of $1927 .^{9}$ As explained in para. 7.1 of this chapter, this draft convention was produced by the

4 LON, Dowble Taxation and Tax Evasion, Report and Resolutions, Document C.115.M.55.1925.II (F.212), Geneva February 7th, 1925.

5 LON, Dowble Taxation and Tax Evasion Repor presented by the committee of Technical Experts on Double Taxation and Tax Evasion, Document C.216.M.85.1927.II., Geneva, April 1927.

6 LON, Double Taxation and Fiscal Evasion, Collection of International Agreements and Internal Legal Provisions for the Prevention of Double Taxation and Fiscal Evasion, Document C.345.M. 102.1928.11, Geneva, October 1, 1928.

7 H. Aufricht, Guide to League of Nations Publications, (Columbia University Press, New York, 1951), p. 214

8 LON. Fiscal Committee, Report to the Conncit on the work of the first session of the committee, Document C.516.M.175. 1929.11, Geneva, October 17-26, 1929

9 LON, Doc.C.216.M.85.1927.II, Geneva, Aprill 1927, p. 11. 
Committee of Twelve, the committee of tax experts appointed by the Financial Committee of the LON in 1922. Art. 5 of this draft states:

\begin{abstract}
"The real centres of management, affiliated companies, branches, factories, agencies, warehouses, offices, depots, shall be regarded as permanent establishments.

The fact that an undertaking has business dealings with a foreign country through a bonafide agent of independent status (broker, commission agent, etc.), shall not be held to mean that the undertaking in question has a permanent establishment in that country."
\end{abstract}

In the commentary on Art. 5 the Committee states that the list of the establishments regarded as permanent are:

"real centres of management, affiliated companies, branches, factories, agencies, warehouses, offices, depots, no matter whether such establishments are used by the traders themselves, by their partners, attorneys, or their other permanent representatives."

This statement in the commentary closely resembles early German concepts. It resembles provisions of early German double taxation conventions, like for example Art. 2 of the 1899 DTC between Prussia and Austria/Hungary. The starting point of the agent as a permanent establishment is, indeed, the establishment. In this PE concept, it is of no relevance if the establishment is actually used by the entrepreneur himself, or by someone else as his permanent representative.

The second sentence of Art. 5 of the 1927 LON convention explains what is not to be considered as an Agency PE. Here the framework of the current Art. 5, para. 6 $\mathrm{OECD}$ provision is laid down, namely the exclusion of the broker, general commission agent or other independent agent from the Agency PE definition. In the commentary the term bonafide agent is explained:

"The words bonafide agent of independent status are intended to imply absolute independence, both from the legal and economic point of view. The agent's remuneration must not be below what would be regarded as a normal remuneration.","11 
So the agent must be a genuine agent- not a front man. It's more than likely that German case law had some influence on this interpretation. German case law in the $1920 \mathrm{~s}$ and $30 \mathrm{~s}$ often dealt with the question of whether the agent could be considered to be an independent agent or not. ${ }^{12}$ It's certain that the implementation of an exemption for the independent agent came as a reaction to the practice of the UK Board of Inland Revenue. In the early 1920s the Board sought to assert taxing jurisdiction over non-residents who sold goods through a local commission agent or broker, if the contracts were concluded within the UK. This resulted in a provision in the code which later became the model for the independent agent clause in the tax treaties. ${ }^{13}$ The English representative in the committee of technical experts (Sir Percy Thompson, Deputy Chairman, Board of Inland Revenue) at this stage could have referred to English legislation. Indeed, the U.K. Finance Act of 1925 contained a similar provision.

The exception for independent agents found in the draft is a limitation of the source-state's jurisdiction to tax income earned through agencies, compared to a number of Post-World War I treaties where no such reservation was made. Most of the double taxation agreements that were concluded until the end of the $1920 \mathrm{~s}$ did not distinguish between dependent and independent agents. Since 1927 the exception for independent agents is a comerstone in the agency clause. ${ }^{14}$

\subsubsection{The Agency PE in Tax Treaties from 1921-1929}

After the drafting of the LON 1927 Draft Convention was completed, the Fiscal Committee continued its work. The economic and financial section of the secretariat of the League of Nations prepared, in accordance with the Council resolution of September 15th, 1927, a collection of international agreements and internall legal provisions for the prevention of double taxation and fiscal evasion. ${ }^{15}$ Not one of the treaties compiled in this report contains a provision similar to Art. 5 of the Draft Convention of 1927. Almost all the treaties, mainly treaties concluded by Germany, did have a provision establishing a tax liability for principals acting through a permanent representative. An example can be found in the 1925 treaty between Germany and Hungary. Art. 2, para. 2 of that treaty states:

12 For example RFH 13 September 1929, in which case the issue was if the manager of a German insurance company was a completely independent agent of an English insurance company; or RFH 28 June 1935, where the court explains when an agent is considered to be dependent on his principal. Further information on the case law can be found in $\$ 3.4 .2$ of this study.

13 A.A. Skaar; p. 474

14 Bbid., p. 475.

15 LON, Document C.345.M. 102.1928.1I, Geneva, October 1st, 1928. 
"The term 'business establishment' shall include the manager's office, branch establishments, workshops, offices where purchases or sales are effected, depots, branches, and all other establishments maintained for the purpose of carrying on the industry by the owner himself, or by his partners, responsible agents or other permanent representatives."

This Agency PE provision is a copy of the provision of the 1899 treaty between Prussia and Austria/Hungary. However, in the treaty between Germany and Sweden of 1928, the independent agent is mentioned in the final protocol. Para. 6 of the final protocol stipulates:

"It is agreed that the maintenance of business relations exclusively by means of a completely independent representative shall not constitute a business establishment (Betriebsstätte) in the sense of Article 3. The same shall apply in regard to the maintenance of a representative (agent) who, whilst permanently acting for individuals or companies of the one State within the territory of the other State, only negotiates business without being fully authorised to conclude transactions on behalf of the firm he represents." 17

Art. 3, para. 1 and 2 , of the treaty between Germany and Sweden of 1928, states:

"(1) Income derived from the exercise of commerce, industry or any other form of business shall, without prejudice to the following provisions, be taxable only in that State in whose territory the undertaking has its business establishment (Betriebsstätte); the same shall also apply when the undertaking extends its activities to the territory of the other contracting State without possessing therein a business establishment.

(2) For the purposes of the present Agreement, a business establishment (Betriebsstätte) is a permanent business installation of the undertaking, in

16 Treaty between Germany and Hungary for the adjustment of taxation at home and abroad, in particular for the avoidance of double taxation in the field of direct taxation, signed in Berlin, November 6, 1928, LON, Document C.345.M.102.1928.II, Geneva, October 1st, 1928, page 36 (translated report). The original German text can be found in Reichsgesetzblatt 1925, Teil II, p. 641.

17 Agreement between the German Reich and the Kingdom of Sweden for the adjustment of internal and external taxation, and, in particular, for the prevention of double taxation in the special matter of direct taxes, signed in Berlin, April 25, 1928, LON, Document C.345.M.102.1928.11, Geneva, October 1st, 1928 , p. 68 . 
which the activities of the said undertaking are carried on either wholly or in part."

Two types of agents are mentioned specifically: the completely independent representative and the representative who merely acts as a negotiator. The agent fully authorised to conclude contracts on behalf of the firm he represents was considered to be a ständiger Vertreter (Agency PE). The activities of the agent who merely negotiates business without being fully authorised to conclude contracts on behalf of the firm he represents, were not considered to justify qualification of the agent as an Agency PE. The latter agent does not replace his principal, when conducting his business. The agent merely conducts supportive activities or duties.

The Fiscal Committee noted that the number of documents signed was not very great. The impact of the 1927 Draft convention was insignificant. The Fiscal Committee contributed this effect to the recent date of the convention.

\subsubsection{Report of the Fiscal Committee (1929)}

The Fiscal Committee reported to the Council on the work of the first session of the committee in Geneva from October 17-26, 1929, and it placed various questions on its agenda, such as the examination in detail of:

1. Measures to be taken to avoid double taxation of income derived from patents and from author's rights;

2. Rules for the apportionment of profits or capital of industrial or commercial enterprises operating in several countries;

3. Measures for the avoidance of double taxation of trusts and companies owning large amounts of easily transferable securities. ${ }^{18}$

For this study it's important to note that the Fiscal Committee decided to add to the above-mentioned questions the study of the definition of the term "autonomous agent" and "permanent establishment". The reason for this additional study can be found on page 3 of the report:

"The Fiscal Committee placed various questions on its agenda, and decided to add to them the study of the definition of the terms 'autonomous agent' and 'permanent establishment', which, if universally recognised, would greatly facilitate the application of the rules 
incorporated in the Model Conventions relating to the taxation of foreign undertakings."

The committee considered four different criteria employed in different countries to determine if an agent can be regarded to be autonomous and thus does not lead to tax liability for the foreign principal, namely the power to conclude contracts, the having of a fixed depot, the retaining of fixed emoluments and finally the continuity of the relation between agent and principal. All these four criteria were examined and no criterion was found to be sufficient to be used for distinguishing between agents that claim to be autonomous agents. Further, it's interesting that the committee does not mention the term "acting in the name of".

The committee then formulated a general principle governing the matter:

"When a foreign enterprise regularly has business relations in another country through an agent established there, who is authorised to act on its behalf, it shall be deemed to have a permanent establishment.".19

This principle shows clear resemblance to the current Art. 5, para. 5 provision of the OECD Model Treaty. It was then considered that a duly accredited agent, who habitually enters into contracts on behalf of the enterprise for which he works, constitutes a PE. A duly accredited agent is an agent who has the authority, for example by means of a power of attorney or mandate, to conclude contracts on behalf of his principal. Although the report does not mention that the duly accredited agent concludes contracts in the name of the principle, the latter can be derived from the above-mentioned general principle. The authorisation thus can only refer to the external relationship, namely between the agent and the third party. A duly accredited agent is an agent who has the power, granted by the principal in the internal relationship (meaning the relationship between principal and agent), to act externally (towards third parties) as an agent who has enough legal power to bind the principal. The habitually acting on behalf of the principal, was the next element of the current Agency PE definition that can be recognized from the 1929 report. From then onwards new treaties require the habitual exercise of that authority, changing the determination from one of theoretical power to one of actual practice. ${ }^{20}$

19 See supra note $204, \mathrm{p} .4$.

20 H.I. Lazerow, The OECD Drafi Influence on United States Income Tax Treaties, Publication no. 24 (International Bureau of Fiscal Documentation, Amsterdam, 1976), p. 36. 
Regarding the broker and commission agent the committee states on page 4 of their report:

"A broker who places his services at the disposal of an enterprise in order to bring it into touch with customers does not, in his own person, constitute a PE of the enterprise, even if his work for the enterprise is continuous or carried on at regular periods.

Similarly, a commission agent (commissionnaire) who acts in his own name for any number of undertakings and receives the normal rate of commission does not constitute a $\mathrm{PE}$ of any of the undertakings he represents."

The committee translated the English term "commission agent" into the French commissionnaire. They further elaborate on the commission agent at the bottom of page 4 of their report:

"It is important to distinguish the agent who constitutes a permanent establishment from the commission agent (commissionnaire) who acts in his own name and not in that of the party for whose account he acts. The commission agent is, under the law of many countries, an independent person in business for himself and is responsible to persons buying from him the products which the real vendor has shipped him to sell.

In most instances, the buyers do not know the real seller and the latter does not know the buyers. Each looks to the commission agent, whose primary role is that of a responsible intermediary between sellers and buyers who would otherwise have difficulty in entering into communication. He usually disposes in wholesale of consigned stocks and keeps no permanent stock on behalf of any one seller.

The commission agent (commissionnaire) in this sense is not to be confused with the so-called commission agent (agent à la commission) who has a stock of goods belonging to a foreign enterprise on consignment, and makes retail sales out of it continuously for the account of the foreign enterprise. Such a "commission agent" usually acts expressly, if not in fact, for the foreign enterprise, inasmuch as the contract of sale or invoice usually bears the name of the foreign enterprise and the agent usually signs on its behalf."

The last mentioned agent $\dot{a}$ la commission is indeed an agent who concludes contracts in the name of the principal. In this case the contract usually is a standard 
contract based upon fixed prices determined by the principal. The broker is, according to the committee, not an Agency PE because he merely brings an enterprise into touch with customers. The regular commission agent is not an Agency PE because he acts in his own name for any number of undertakings. The second quote of page 4 (bottom page) of the report further distinguishes the commission agent from the Agency PE by stressing the fact that the commission agent is an independent person in business for himself. The commission agent is responsible to the persons buying from him and secondly to the real vendor. The real vendor, the person who concluded a commission agreement with the commission agent, is in fact an undisclosed principal (and so an undisclosed vendor). The person who buys goods from the commission agent, does not necessarily know the identity of the real vendor.

So in this instance its logical that the committee states that the commission agent "is responsible to persons buying from him the products which the real vendor has shipped him to sell". The real vendor, of course, is the principal on whose behalf the commission agent operates. The commission agent acts on behalf of the principal if the principal concluded a commission agreement with the commission agent, authorising the commission agent to sell goods for a certain price. The responsibility is- in my view - a legal one, namely the legal liability of the commission agent to the buyer. The principal is undisclosed, so the buyer can only put his legal claim before the commission agent. This is a typical civil law standpoint. In fact, in common law the commission agent is a form of agency with an undisclosed principal. ${ }^{21}$

The commission agent who keeps no permanent stock on behalf of any one seller, is what the French call a commissionnaire. Under French law, according to Art. 94 of the Code de Commerce, the commissionnaire is defined as a person who acts in his own name and on behalf of others. ${ }^{22}$ Article 94 of the French Code de Commerce reads:

"The commission agent is the one who acts in his own name or in his business name and on the account of the principal. The rights and duties of the commission agent are being determined under the Civil Code. ${ }^{, 23}$ [See Appendix, Quote 22 for original in French.]

21 See Chapter II on legal issues regarding the agency.

22 R. Baaldi, Distributorship, Franchising, Agency, Community and National Laws and Prachice in the EEC, (Kluwer, Deventer, 1987), p. 109.

23 Code de Commerce, Quatre-Vingt-Onzième édition, edited by Yves Chaput, Paris 1995. 
The agent a la commission, however, is an agent who has a stock of goods belonging to a foreign enterprise on consignment, and makes retail sales out of it continuously for the account of the foreign enterprise. The meaning of retail sales in this context is selling goods in small quantities, opposite to selling goods in wholesale, and with the invoice in the name of the principal. Such a commission agent, according to the committee, acts in the name of the principal and thus constitutes an Agency PE. Although the committee does not state that the agent a la commission constitutes an. Agency PE, I think that there can be no other conclusion based upon the reasoning of the committee on page 4 of their report. He also satisfies the general principle of the Agency PE, formulated by the committee.

Concerning the Agency PE, the committee concluded that the essential elements of the relationship between the agent and the foreign enterprise are:

1 - The authorisation given to the agent to act for the foreign enterprise; and 2 - The fact of his carrying out these transactions regularly; and 3 - The fact of his carrying them out in an establishment. ${ }^{24}$

The authorisation mentioned in the first element is, according to the committee:

"A criterion of a legal nature, it being considered that the only agents dependent on an enterprise are those having sufficient powers to conclude contracts binding upon that enterprise., 25

According to the committee, the authorisation given to the agent is the duly accredited power of the agent to legally bind his principal. In a strictly civil law sense, this could only mean that the agent has the power to conclude contracts in the name of the principal. The meaning of the term "dependent" is somewhat vague. In previous LON reports the Agency PE is not mentioned as a dependent agent. The 1927 LON report only refers to agents of independent status. ${ }^{26}$ So perhaps the term "dependent" is only used to emphasize the difference with the independent agent. The agent legally binding the principal constitutes, when he complies with the other two elements, an Agency PE. 
The committee excludes from this Agency PE concept:

"(1) Casual or even frequent transactions through a broker, because such an intermediary merely brings the parties together;

(2) Sales through a commission agent who acts in his own name for any number of parties;",27

Firstly, the broker is not an agent because he does not conclude contracts. Instead, the broker brings parties together who then can, if they wish to do so, conclude contracts between themselves. The broker is not a contracting party. This reasoning would, in my view, justify the exclusion of the broker of the Agency PE concept on these very grounds. The exclusion of the broker in a separate provision is therefore unnecessary. My second conclusion would be that the commission agent is excluded by the committee of the Agency PE concept, because the commission agent does not conclude contracts in the name of the principal. He also acts for any number of principals, which could mean that the committee was uncertain whether the commission agent who acts for just one single principal should be excluded from the Agency PE concept. The committee also formulates that the commission agent must receive the normal rate of commission. I think this particular reference indicates that the committee had a typical independent commission agent in mind, one that is economically and legatly independent of his principals. The term principal is in this case misplaced; a commission agent has customers or clients. For the sake of clarity, however, I will keep on using the term principal.

According to civil law tradition, the agent binds the principal if the agent acts in the name of the principal. English common law however expresses the rule of agency in the maxim

"He who does an act through another is deemed in law to do it himself." 28 Or as G.H.L. Freedman states:

"Agency is the relationship that exists between two persons when one, called the agent is considered in law to represent the other, called the principal in such a way as to be able to affect the principal's legal position in respect of strangers to the relationship by the making of contracts or the disposition of property. ${ }^{.29}$

27 LON, Document C.516.M.176. 1929.II, Geneva, October 26, 1929, p. 4.

28 H. H. Lidgard, C. D. Rohwer, \& D. Campbell, A survey of commercial agency, p. 107 (The U.K. report).

29 G.H.L. Fridman, The Law of Agency, quoted from Lidgard/Rohwer and Campbell, A survey of commercial agency, p. 108. 
According to civil law only an agent who concludes contracts in the name of the principal legally binds the principal to the contract. According to common law the actual contracting in the name of the principal by the agent is not the decisive factor in the agency relationship. A common law agent may even bind an undisclosed principal when acting as an agent. Even if the third party has no knowledge of the fact that his contracting partner is in fact an agent (the undisclosed agent), the agent binds the principal. So, from a common law perspective, an agent could not have the authority to conclude contracts in the name of his principal, but in fact does conclude binding contracts.

Further, the second element, regarding the criterion of regularly carrying out transactions, points to the continuity of the relations between the agent and the principal. The final element, namely the fact that the agent carries out his business in an establishment, is clearly based upon the general PE concept, and is explained by the committee as follows:

"(1) When the agent carries out the whole or part of his activities in an office or other premises placed at his disposal by the enterprise;

(2) When the office or premises where the agent carries out the whole or part of his activities are designated by outward signs as being an establishment of the enterprise itself."

These elements both point to a certain known "presence" of the principal in the agents state. If the agent has an office with outdoor signs with the name of his principal, it would be logical to assume that the designated agent would only act in the name of that same principal. $I$ think that in this case a "regular" permanent establishment is present, because of this fixed place of business. These facts are in contrast with the agent who, like for example the commission agent, is in fact in business for himself and has his own office or premises.

\section{3 \\ THE AGENCY PE ACCORDING TO THE LEAGUE OF NATIONS (1930-1947)}

The League of Nations published in 1932 a study of the tax systems and the methods of allocation of the profits of enterprises operating in more than one country. Five countries were investigated: France, Germany, Spain, the United Kingdom and the United States of America. ${ }^{30}$ Specifically, the German double

30 LON, Taxation of Foreign and National Enterprises, League of Nations, Geneva, 1932. 
taxation treaties in those days included permanent agencies under the PE concept. This report mentions on page 115 , regarding the independent agent:

"It is expressly stated that the term "permanent establishment" does not include the maintenance of business relationships merely through a completely independent agent, or the maintenance of a representative (agent), who, although he is constantly employed on behalf of individuals or corporations of one State in the territory of the other State, merely acts as intermediary in effecting business transactions without being empowered to conclude the transactions on behalf of the firm which he represents."

It seems that the term "completely independent agent" refers to the commission agent, while the latter agent, the intermediary, seems appropriate for the broker. The general concept of the Agency PE is put into words by Mitchell B. Carroll in his 1939 evaluation report on two decades of work by the League of Nations. ${ }^{31}$ "When a foreign enterprise regularly has business relations in a State through an agent established there who is authorised to contract on its behalf, it shall be deemed to have a permanent establishment". Mitchell B. Carroll further states:

"In accordance with the foregoing principle, a permanent establishment shall be deemed to exist when the agent in the state: (1) is a duly accredited agent who habitually enters into contracts for the enterprise for which he works; (2) is bound by an employment contract and habitually contracts commercial business on behalf of the enterprise in return for remuneration or (3) is habitually in possession for the purpose of sale of a depot or stock of goods belonging to the enterprise.

It is furthermore specified that the term does not include a broker who places his services at the disposal of an enterprise in order to bring it into touch with customers, or a commission agent who acts in his own name for one or more enterprises and receives a normal rate of commission." 32

These comments on the Agency PE concept are a brief summary. No new thoughts can be derived from these comments, or perhaps only the fact that Carroll also excludes the commission agent who acts in his own name for one or more

31 M.B. Carroll, Prevention of International Double Taxation and Fiscal Evasion, Two Decades of Progress under the League of Nations, Official no.: F./Fiscal/1 11, Geneva, June 22, 1939, pp. 32 \& 33.

32. See supra note 216, p. 33. 
enterprises. This would imply that an exclusive commission agent, according to Carroll, does not constitute an Agency PE if he acts in his own name. This is a surprising conclusion, and in my view solely attributable to Carroll's view, because the Fiscal Committee did not address this issue in their 1929 report, or for that matter, in other LON reports. Carroll describes what kind of agent certainly constitutes an Agency PE. He does not ellaborate on what condition is decisive in determining an Agency PE.

\subsection{THE INTERNATIONAL CHAMBER OF COMMERCE}

The International Chamber of Commerce (ICC) developed several initiatives concerning the problem of international double taxation. It did not approach the technical difficulties pertaining to this problem in terms of drafting modell treaties. ${ }^{33}$ It first paid attention to the Agency PE, and recommended a three-fold test to define one, at its Washington conference in May 1931, under the following criteria:

1 - An authority to act on behalf of the principal;

2 - The habitually performing of such acts of trade;

3-A fixed place of business.

These three elements are exactly the same elements as the Fiscal Committee of the LON formulated in their 1929 report. $^{34}$ Also interesting is the fact that the US Revenue Act 1936 contained a special proviso concerning the broker and commission agent. Section 211 (B) of that Act states:

"A nonresident alien individual engaged in trade or business in the US...shall be taxable.

Such phrase does not include the effecting of transactions in the U.S. in stocks, securities or commodities through a resident broker, commission agent or custodian."

In this case the US broker and commission agent who trade in stocks or securities on behalf of a foreign principal (the client), did not create tax liability for their foreign principal.

33 A.A. Skaar, op cit., n. 13, p. 80.

34 LON, Document C.516.M.176.1929.11, Geneva, October 26, 1929.

35 U.S. Revenue Act 1936, 74th Congress session 11.Ch.690, June 22, 1936, Supplement H nonresident aliens, Section $211(\mathrm{~B})$. 
3ecause of the politicall situation in the late $30 \mathrm{~s}$, and the outbreak of the Second Norld War, the League of Nations Fiscal Committee did not resume their ictivities until after the war. The first major event was the tax conference in Mexico on July 1943, and the three-fold test recommended by the ICC was also used in the Mexico/London Model Conventions.

\subsection{THE MEXICO/LONDON MODEL CONVENTIONS}

\subsubsection{Introduction}

In Mexico (1943) and in London (1946) two model conventions were drafted by he Fiscal Committee of the League of Nations. Because of World War II the Mexico conference was not attended by major European countries. The model zonvention drafted in Mexico received a lot of criticism from the London zonference. Effective divergence between the views of the 1943 Mexico meeting and those of the 1946 London meeting are those relating to the taxation of interest, dividends, royalties, anmuities and pensions. ${ }^{36}$ There was however agreement on Agency PE provisions. The Mexico and London Conventions continued, from the earlier work of the Fiscal Committee, the provisions which allow a distinction to be made between dealings through an autonomous agent and those through a permanent establishment or branch.

\subsubsection{The Agency $\mathrm{PE}$ according to the Mexico/London Conventions}

The text of the model bilateral convention for the prevention of the double taxation on income, concluded July 1943 in Mexico, did not contain a specific provision concerning the Agency PE. The term permanent establishment is mentioned in a couple of articles (articles IV \& VII), but never defined. The protocol to the Mexico model, however, does elaborate on the Agency PE concept. Article V of the protocol, paragraphs 3-5, states:

"3. The fact that an enterprise established in one of the contracting States has business dealings in another contracting State through an agent of genuinely independent status (broker, commission agent, ete.) shall not

36 LON, London and Merico Madel Tax Connentions, Commentary and Text, Official no: C.88.M.88.1946.II.A., Geneva, November 1946, p. 6. 
be held to mean that the enterprise has a permanent establishment in the latter State.

4. When an enterprise of one of the contracting States regularly has business relations in the other State through an agent established there who is authorised to act on its behalf, it shall be deemed to have a permanent establishment in that State.

A permanent establishment shall, for instance, be deemed to exist when the agent:

A. Is a duly accredited agent (fond de pouvoir) (f) $^{37}$ and habitually enters into contracts for the enterprise for which he works; or

B. Is bound by an employment contract and habitually transacts business on behalf of the enterprise in return for remuneration from the enterprise; or

C. Is habitually in possession, for the purpose of sale, of a depot or stock of goods belonging to the enterprise.

5. As evidence of an employment contract under the terms of B above may be taken, moreover, the fact that the administrative expenses of the agent, in particular the rent of the premises, are paid by the enterprise.

These paragraphs were completely in line with previous reports of the Fiscal Committee of the League of Nations. Because the protocol states in the second sentence, under 4., that "a PE shall, for instance, be deemed to exist...", I am inclined to conclude that the protocol does not give a restrictive summary of relevant elements constituting an Agency PE, but merely gives examples.

The evaluation report by Mitchell B. Carroll on two decades of work by the LON, contains exactly the same ideas on the Agency PE. ${ }^{39}$ The Commentary on the Mexico model formulated four distinct criteria according to which a foreign enterprise may be deemed to have a PE in the country where it deals through an agent. These criteria are exactly the same criteria as Mitchell B. Carroll formulated in his 1939 report. The commentary states:

37 The French term fondes de powwoir literally means "deputy manager". The German expression is Prokwrist. As the duly accredited agent, these expressions have in common that the agent is an agent who has either power of attoney or a mandate to act on behalf of the principal.

38 LON, Model Bilateral Conventions for the Prevention of International Double Taxation and. Fiscal Evasion, Mexico, D. F., July 1943, Geneva 1945, Official No.: C.2.M.2. 1945.II.A., pp. 15 \& 16.

39 M.B. Carroll, Prevention of International Double Taxation and Fiscal Evasion, Two Decades of Progress under the League of Nations, Official no: F.JFiscal/111, Geneva, June 22, 1939. 
"...there seems to be consequently four distinct criteria according to which a foreign enterprise may be deemed to have an establishment in the country where it deals through an agent: (a) power of the local agent to bind the enterprise; (b) existence of a contract of employment with a local agent; (c) maintenance in the country of a stock of goods under the control of an agent for sales in that country; (d) payment of the rent of the premises used by the agent and of his office expenses. Any of these four conditions is sufficient to render an enterprise liable to income tax in its own name in the country where an agent operates, provided that the condition which is fulfilled corresponds to a permanent state of things or an habitual practice." 40

In the commentary it is stated that any of the four conditions are sufficient to constitute an Agency PE. This certainly is a new approach. In the LON's 1929 report $(\$ 7.2 .3)$ the Fiscal Committee stated that no criterion was found to be sufficient for the constituting of an Agency PE. The first criterion ("the power to bind the enterprise") emphasises the legal implications of the activities of an agent. If the agent binds the principal, an Agency PE is constituted. This legal criterion was already used in the 1929 report of the Fiscal Committee." The criterion of the power to bind is explained in the Commentary as follows: "The agent habitually acts in the name of the enterprise concemed as a duly accredited agent and enters into contracts on its behalf'. This comment was made when the Fiscal Committee elaborated on the differences between the autonomous agent and the dealings through a permanent establishment or branch. The commission agent (see $\$ 5.5 .3$ ) is referred to as an agent who acts in his own name. The Agency PE is therefore defined as an agent who has the authority (duly accredited agent) to act in the name of the principal.

The second criterion, the employment contract, can be traced back to the 1927 Draft convention of the Committee of Technical Experts. ${ }^{42}$ Here the replacement theory (see Chapter $2 \S 2$ of this book), which originated from German Treaty provisions at the end of last century, is embodied. This criterion serves as an example of the regular Agency PE. The employee replaces the employer, which therefore creates tax liability for his employer. The employee is an example of an agent who solely acts in the name of and certainly on behalf of his principal. His

40 LON, Document C.2.M.2. 1945, II.A. p. 46.

41 LON, Report to the council on the work of the first session of the committec, Document C.516.M.176.1929.II, Geneva, October 1929, p. 3.

42 LON, Document C.216.M.85.1927.1I, p. 15. 
principal at the same time is his employer. Meanwhile, Skaar emphasises another aspect:

"The employment contract could be characterised as a specific assignment, in which the agent (the employee) normally has a high degree of dependency upon the principal. Thus, the employer usually has the right to instruct the employee in almost all aspects concerning the business activity."

The maintenance of a stock of goods by the agent on behalf of the principal is a provision commonly used in the older US treaties. The older US treaty definitions, like for example the 1948 Danish treaty, define as an Agency PE the agent who has a stock of merchandise from which he regularly fills orders on behalf of his principal. ${ }^{44}$ The final criterion can be classified under, what Skaar refers to as, the dependency test: the principal pays the rent of the premises used by the agent, and the agent in question can be regarded as economically dependent on his principal, thereby constituting an Agency PE. In this case the principal has the power of disposal of premises in the agent's state. Consequently, the principal is physically present in the other country through his agent. ${ }^{45}$ In conclusion, the London model convention (1946) copied the Agency PE comments in the Commentary of the Mexico model.

\subsubsection{The Independent Agent}

According to Article V, paragraph 3, Mexico Model Protocol, a foreign enterprise is not liable to income tax in a country if its operations in that country are exclusively carried out through a broker, commission agent, or other agent of a genuinely independent status in that country. Art.V, para. 6, Mexico Model Protocol, further elaborates on the broker and commission agent:

"6. The fact that a broker places his services at the disposal of an enterprise in order to bring it into touch with customers does not in itself imply the existence of a permanent establishment for the enterprise, even if his work for the enterprise is, to a certain extent, continuous or is carried on at regular periods, and even if the goods sold have been temporarily placed in a warehouse."46

43 A.A. Skaar, op cit., n. 13, p. 504.

44 J.E. Bischel, Inconte Tax Treaties, (Practising Law Institute, New York, 1978), p. 216.

45 A.A. Skaar, op cit, n. 13, p. 503.

46 The last part of this sentence is italicized by the author of this study. 
Similarly, the fact that a commission agent (commissionmaire) acts in his own name for one or more enterprises and receives a normal rate of commission does not constitute a permanent establishment for any such enterprise, even if the goods sold have been temporarily placed in a warehouse.

Paragraph 6 is almost completely copied from the 1929 report of the Fiscal Committee (Cf. $\$ 5.2 .5$. of this study). Only the last part of the first sentence, which is italicized, was added to the Protocol. Sidney Roberts ${ }^{47}$ concludes that the broker described above, is a broker according to civil law traditions. I agree with this conclusion of Roberts. According to Roberts the texts of the earlier League of Nations Models ${ }^{48}$ incorporate the civil law concept of direct representation by excluding brokers, who do not generally conclude contracts. The rationale for excluding brokers is, according to Roberts, the fact that the broker does not conclude contracts in the name of the foreign enterprise, nor does he do so in his own name. ${ }^{49}$ This view would imply that brokers would never constitute an Agency PE, providing they acted in the normal course of their business, because the broker does not conclude contracts, and therefore a broker is, from a legal point of view, not an agent. The exclusion of the broker, e.g., according to Art. 5(6) of the OECD Model, seems- on the basis of these arguments- pointless and redundant. On the other hand, in the civil law systems, authority is usually understood as the competence or power to act in the name of the principal, whereas in the common law the notion of authority is not necessarily linked with acting in the name of someone else. ${ }^{50}$

The remarks in the Protocol on the commission agent support the civil law basis, as Roberts suggests. According to civil law an agent who acts in the name of his principal directly binds his principal. If the agent concludes contracts in the name of his principal, he thus acts recognisably on behalf of his principal and is thereby directly representing his principal. This type of representation is in civil law referred to as direct representation. This is in contrast with indirect representation which in fact is no representation. The term "indirect" implies that the acting person does not pretend to act on behalf of someone else, but implies that he intends to legally bind himself vis-à-vis the third party. ${ }^{51}$ Because the civil law

47 S.I. Roberts, "The Agency Element of Permanent Establishment: The OECD Commentaries from the Civil I aw View (Part One)', Jitertax $1993 / 9$, p. 412.

48 Roberts refers to the 1929 Report of the Fiscal Committee.

49 S.I. Roberts, op cit, n. 49 , p. 413.

50 H.L.E. Verhagen, Agency in Private Intemational Law, p. 144.

51 I would like to refer to Chapter II of this study, which is dedicated to issues such as the civil and common law concept of agency and representation. 
commission agent acts in his own name, he does not legally bind his principal when the concludes contracts with third parties.

While the LON used to treat the broker and commission agent as two different kinds of agents, the Mexico Model treats them as being one group, namely the agents of a genuinely independent status. This cannot be right, because the broker only brings parties together. Therefore, the broker is not an agent. Article $\mathrm{V}$, para. 6, Mexico Model Protocol, states: "an agent of genuinely independent status (broker, commission agent, etc.)". The draughtsmen gave examples of a genuinely independent agent, by referring to the broker and commission agent between brackets. The use of the abbreviation "etc.", short for et cetera, points to the fact that the draughtsmen did not limit their genuinely independent agent only to the broker and commission agent.

\section{6.}

\section{OEEC 1958 REPORT}

The Fiscal Committee of the OEEC ${ }^{52}$, predecessor of the OECD, issued a report on the elimination of double taxation in $1958 .^{53}$ The reason for this report was, among other things, the lack of double taxation conventions between many countries. Because of the increasing post-war development of economic relations between OEEC member states and the increasing interdependence of their economies, cases of double taxation remained. The observation was made that bilateral treaty provisions were by no means uniform. The effect was that identical problems were subjected to different and more or less satisfactory solutions. ${ }^{54}$

The aim of the committee's work (Chapter 3 of the report) was to study four subjects:

1. listing and defining taxes on income and capital (including taxes on estates and inheritances) which should be covered by double taxation agreements;

2. the concept of permanent establishment;

3. the concept of fiscal domicile;

4. tax discrimination on grounds of nationality or similar grounds.

52. The abbreviation OEEC stands for Organisation for European Economic Co-operation.

53 OEEC, The elimination of double taxation, report of the tiscal committee of the OEEC, Paris 1958.

$54 \mathrm{lbid}, \mathrm{p} .11$. 
The OEEC Fiscal Committee proposed to establish a series of articles which, taken together, would finally cover all the problems which the bilateral double taxation conventions were designed to solve and would thus constitute a Model Bilateral Convention acceptable to all member countries. In this OEEC model convention, the Agency PE definition is as follows:

\section{"4. A person acting in a Contracting State on behalf of an enterprise of the other Contracting State- other than an agent of an independent status to whom paragraph 5 applies- shall be deemed to be a permanent establishment in the first-mentioned State if he has, and habitually exercises in that State, an authority to conclude contracts in the name of the enterprise, unless his activities are limited to the purchase of goods or merchandise for the enterprise. \\ 5. An enterprise of a Contracting State shall not be deemed to have a permanent establishment in the other Contracting State merely because it carries on business in that other State through a broker, general commission agent or any other agent of an independent status, where such persons are acting in the ordinary course of their business. ${ }^{.55}$}

In the commentary on the article on permanent establishment, the OEEC Fiscal Committee adheres to the LON Fiscal Committee's standpoint. The OEEC defines the Agency PE concept as follows:

"Treatment as a permanent establishment should be limited to dependent agents of those enterprises which, in view of the scope of their agent's authority or of the nature of their agent's business dealings, take part to a particular extent in business activities in the other State. Therefore, the Article proceeds on the basis that only persons having the authority to conclude contracts shall be treated as permanent establishments." ${ }^{.56}$

The OEEC Fiscal Committee refers, in this respect, to the Report of the Fiscal Committee of the League of Nations from 1928, page 12. I believe that the date in question must be 1927, not 1928. In 1928 only a collection of international agreements for the prevention of double taxation was published by the LON. However, the above-mentioned position can be exactly traced back to the LON 1927 Draft Convention. ${ }^{57}$

55 lbid. Appendix II Article on permanent establishment, para. 4 \& 5, pp. 33-34.

56 Ibid, p. 51.

57 I would like to refer to $\$ 7.2 .1$ of this study. 
The phrase in the OEEC Agency PE definition "the authority to conclude contracts" is based upon the view that an Agency PE should be limited to dependent agents of those enterprises which, in view of the scope of their agent's authority or of the nature of their agent's business dealings, take part to a particular extent in business activities in the other state. ${ }^{5 \%}$ Concerning the term "general authority", commonly used in older treaties, the word "general" was omitted. The committee felt it unlikely that any dependent agent would have a completely unfettered authority to conclude contracts. In all cases the authority would be limited to some extent.

Concerning the independent agent, the OEEC Fiscal Committee again agreed with the League of Nations' position. In this case, they referred to the Mexico and London Drafts. However, there is one major contribution to the work of the OEEC Fiscal Committee: the independent agents are only considered not to constitute an Agency PE if they are acting in the ordinary course of their business. In the commentary the following reason for this addition is explained:

"Where, for example, a commission agent not only sells the goods or merchandise of the enterprise in his own name but also habitually acts, in relation to that enterprise, as a permanent agent having an authority to conclude contracts, he would be deemed in respect of this particular activity to be a $\mathrm{PE}$ since he is thus acting outside the ordinary course of his own trade or business (namely that of a commission agent). ${ }^{, 59}$

In my view, this important commentary adheres to the Mexico/London Commentary concerning the commission agent. The commission agent who concludes contracts in the name of the principal, does not act as a commission. agent and therefore acts outside his regular business. The OEEC refers to the typical civil law definition of a commission agent/commissionnaire. The commission agent acts in his own name and thus does not represent a principal. In fact, the commission agent acts on behalf of clients. He does not legally bind any of his clients because he acts in his own name. Only if the commission agent doesn't conclude contracts in his own name, but in the name of a client and the invoice has the name of the client (in this case actually his principal), he does not act as a commission agent but as an agent who is regarded as an Agency PE.

58 OEEC, op cit., n. 55, p. 51.

59 lbid, p. 52. 
This is exactly what Sidney Roberts claims in his Intertax article. ${ }^{60}$ An agent who acts in the name of the principal always constitutes an Agency PE. On this point, I agree with Robert's view. I think the relevant issue in Agency PE taxation is determining to what extent the foreign principal is engaged in business through his domestic agent. The quality of the agent, dependent or independent, is less relevant than the assessment of the activities that the agent performs on behalf of the foreign principal. If the agent concludes contracts in the name of the principal, the principal is liable for those contracts, therefore legally and also commercially present in the agent's country. The fact that the actual agent can further be recognised as an independent agent does not alter the fact that the activities of the foreign principal through his agent fall within the main Agency PE rules. Therefore Agency PE taxation is justified if, for example, an independent agent concludes contracts in the name of the principal.

\section{7}

\section{OECD MODEL TREATY}

\subsubsection{Introduction}

The basic assumption of the 1963 Model was the permanent establishment as the starting point of taxation by the source state of foreigners' activities. Revenues attributable to the PE can be taxed by the source state.

\subsubsection{The Agency PE in the 1963 Model}

Art. 5 , para. 4 states:

"A person acting in a Contracting State on behalf of an enterprise of the other Contracting State- other than an agent of an independent status to whom paragraph 5 applies-shall be deemed to be a permanent establishment in the first-mentioned State if he has, and habitually exercises in that State, an authority to conclude contracts in the name of the enterprise, unless his activities are limited to the purchase of goods or merchandise for the enterprise."

This definition of the Agency PE clearly originates from the 1958 OEEC report. The OECD Commentary declares in para. 15 that the Agency PE is strictly limited to those agents who are legally and economically dependent upon the enterprise

60 S.l. Roberts, op cit, n. 49, p. 489.

61 K. van Raad (Ed.), Model lncome Tax Treaties and Commentaries, 2nd ed., Kluwer. 
for which they carry on business dealings. The Commentary refers to the 1928 League of Nations report, but also the OEEC report of 1958 embodies this principle. Nitikman points to the consequences of the formulation in the 1963 Model Commentary. Only an agent who is legally and economically dependent is a dependent agent. So an agent who is economically dependent but legally independent, cannot be regarded on the basis of the 1963 model as being a dependent agent. ${ }^{62}$ According to Nitikman economic dependence means that the enterprise supplies most if not all of the agent's work. Legally independent is the agent who acts as an intermediary at arm's length distance from the foreign enterprise, or in other words, if the agent's commercial activities for the enterprise are not subject to detailed instructions or to comprehensive control by it. ${ }^{63}$

The "purchasing agents" are also excluded from the Agency PE concept, as can clearly be concluded from the last subordinate clause from Art. 5, para. 4. The reason for this exclusion is the fact that the maintenance of a place of business exclusively for the purchase of goods or merchandise does not constitute a PE on the basis of Art. 4, para. 3, under d, 1963 Model. It was found logical to extend this exclusion also to an agent who has the authority to conclude contracts strictly limited to contracts covering the purchase of goods or merchandise. ${ }^{64}$ Meanwhile, the core of the Agency PE concept is explained in paragraph 16 of the Commentary:

"Treatment as a PE should be limited to dependent agents of those enterprises which, in view of the scope of their agent's authority or of the nature of their agent's business dealings, take part to a particular extent in business activities in the other State.

When the agent has sufficient authority to bind the (enterprise by concluding contracts, the extent of the $)^{65}$ enterprise's participation in the business activity of the other country is such that the agent should be deemed to be a permanent establishment."

62 I. Nitikman, "The Meaning of "Permanent Establishment" in the 1981 U.S. Model Income Tax Treaty: Patr: 2", The Intermational Tax Joumal, p. 267.

63 A.A. Skaar, op cit., n. 13, p. 504.

64 OECD Commentary, paragraph 18, Article 5.

65 The sentence between brackets was left out in the original text of the 1963 Model. It did however appear in the first interim report. Kees van Raad reasoned that without these words the sentence has no meatning whatsoever, Nederlandse Regelingen van International Belastingrecht, part.II.d. As my following plea shows, I do agree with Van Raad. 
The first sentence mentioned above is a confirmation of the fundamental Agency PE principle formulated by the League of Nations Fiscal Committee in their 1929 report: ${ }^{66}$

"When a foreign enterprise regularly has business relations in another country through an agent established there, who is authorised to act on its behalf, it shall be deemed to have a permanent establishment in that country."

The foreign enterprise has in fact the business relations in another country, only not directly but via an intermediary, namely the agent. In my view, the essence of Agency PE taxation is the level of participation of the foreign enterprise in the agent's business activities. The second sentence in the above-mentioned paragraph 16 of the commentary explains what the necessary level of foreign participation must amount to, to trigger Agency PE taxation: the agent must have authority to bind the enterprise by concluding contracts. In a civil law context this can only mean that the agent concludes contracts in the name of the principal. I think that the OEEC Commentary on their 1958 report also clearly points to this conclusion. The remarks on the independent agent acting in the ordinary course of their business especially adheres to this standpoint. The commission agent who acts in the name of the principal, legally binds the principal, and so constitutes an Agency $P E$. If an agent acts in the name of his principal, it can be said that the principal, by means of the agent, conducts business in the agent's state. For example, the principal builds up a clientele, not the agent.

\subsubsection{The Independent Agent}

Art. 5, para. 5 of the 1963 Model reads:

"An enterprise of a Contracting State shall not be deemed to have a permanent establishment in the other Contracting State merely because it carries on business in that other State through a broker, general commission agent or any other agent of an independent status, where such persons are acting in the ordinary course of their business."

In accordance with para. 20 and 21 of the commentary, the truly independent agent is considered not to constitute an Agency PE for the enterprise he represents, if he acts in the ordinary course of his business. The independent agent has an enterprise 
of his own. The core of his business dealings consists of acting as an intermediary between two or more parties. If an enterprise in state A concludes contracts through an independent agent in state $B$, the causal connection is too thin to conclude that the enterprise actually undertakes business dealings in state $\mathrm{B}$. The business dealings in state $B$ are conducted by the independent agent, and the enterprise in question has no further active part in the business dealings in state B. In this case, the independent agent is working within the ordinary course of his business. Concerning my last remark, the commentary contains an example of an independent agent not working within the ordinary course of his business. The example in para. 20 concerns a commission agent:

"Where, for example, a commission agent not only sells goods or merchandise in his own name but also habitually acts, in relation to that enterprise, as a permanent agent having the authority to conclude contracts, he would be deemed in respect of this particular activity to be a permanent establishment since he is thus acting outside the ordinary course of his own trade or business (namely that of a commission agent)."

On the basis of this example, Roberts concludes that the agent who concludes contracts in the name of the principal, does not act within the normal course of his business. He thus always constitutes an Agency PE. ${ }^{67}$ This example can be traced back to the 1958 OEEC report concerning the Mexico/London Model Commentaries.

Furthermore, paragraph 21 of the Commentary states:

"Although it stands to reason that agents of an independent status, representing as they do a separate enterprise, cannot constitute a permanent establishment of the foreign enterprise where they are acting in the normal course of their business..."

In relation to para. 20 of the Commentary, this means that a commission agent does not constitute an Agency PE for the enterprise he represents on the basis of Article 5, para.4 of the 1963 Model. This stands to reason because the commission agent, when acting in the ordinary course of his business, concludes contracts in his own name, not in the name of the enterprise he represents. Essential is the question whether or not the commission agent legally binds his principal. In my view, the writers of the OECD commentary had this in mind, because they state at the end of paragraph 21 of the Commentary that Art. 5, para. 5 of the 1963 Model

67 S.I. Roberts, "The agency element of permanent establishment: The OECD commentaries from the civil law view (Part Two)", Intertax 1993/10, p. 489. 
is retained in the article for the sake of clarity and emphasis, and especially since a similar provision is contained in nearly all of the double taxation conventions.

7.8

1977 OECD MODEL TREATY

\subsubsection{Introduction}

The actual treaty text with regards to the Agency PE provisions shows little difference with the 1963 Model provisions. There were some alterations made in the text, but certainly no changes concerning the content of the Agency PE provisions. ${ }^{68}$ The Commentary, however, was fully rewritten. ${ }^{69}$ The last sentence of para. 30 of the Commentary of the 1977 Model elaborates the rewrite as follows:

"The paragraph has been redrafted to clarify the intention of the corresponding provision of the 1963 Draft Convention without altering its substance apart from an extension of the excepted activities of the person. ${ }^{370}$

\subsubsection{The Agency PE in the 1977 Model}

The Agency PE definition in the 1977 Model is contained in Art. 5, para. 5, which states:

"Notwithstanding the provisions of paragraphs 1 and 2, where a person-other than an agent of an independent status to whom paragraph 6 applies- is acting on behalf of an enterprise and has, and habitually exercises, in a Contracting State an authority to conclude contracts in the name of the enterprise, that enterprise shall be deemed to have a permanent establishment in that State in respect of any activities which that person undertakes for the enterprise, unless the activities of such person are limited to those mentioned in paragraph 4 which, if exercised through a fixed place of business, would not make this fixed place of

68 S.l. Roberts, op cit., n. 49, p. 418.

69 Model Double Taxation Conwention an Income and on Capital, Report of the OECD Committee on Fiscal Affairs, OECD Paris 1977, p. 11.

70 lbid, p. 66 . 
business a permanent establishment under the provisions of that paragraph."

The paragraph starts off with: "Notwithstanding the provisions of paragraphs 1 and 2 ". This means that the activities of the agent need not be measured against the fixed-place-of-business test of Art. 5, para. 1. Through the agency rule, a foreign enterprise may have a permanent establishment even in the absence of a fixed place of business of the foreign enterprise. ${ }^{71}$

Para. 31 of the Commentary limits the definition of the Agency PE to: "persons who in view of the scope of their authority or the nature of their activity involve the enterprise to a particular extent in business activities in the State concemed." Although certainly the term "particular extent" is fairly vague, I think that this comment in para. 31 of the Commentary must be regarded with the 1963 Commentary in mind. The enterprise is in fact involved in business activities in the agent's state, when the agent: "has sufficient authority to bind the enterprise's participation in the business activity in the State concerned" (para. 31 Commentary). Skaar concludes that this statements seems to emphasise the material relationship between the agent and the principal, and not the parties in the formal conclusion of the contract. ${ }^{72}$ Although the first condition, namely the actual involvement of the enterprise in the business activities of the agent, indeed points to a mere material aspect, the connection with the binding of the enterprise clearly points to a legal connection with the third party. The enterprise is bound by contract, according to civil law, when the agent concludes contracts in the name of the enterprise. If that is the case, the enterprise is legally a contract partner concerning the contracts concluded by its agent. The enterprise's quality as contract partner can certainly be regarded as the above-mentioned required actual involvement in the agent's state.

The Commentary further stipulates that the authority to conclude contracts must cover contracts relating to operations which constitute the business proper of the enterprise. ${ }^{73}$ "The core activity of the enterprise is decisive whether or not the agent can be considered to constitute an Agency PE. If an industrial enterprise engages an agent only for supporting activities, such as taking on employees or undertaking advertising or public relations activities, the agent does not conclude contracts relating to the business proper of the enterprise (in this case industrial activities).

71 J. Nitikman, "The Meaning of "Permanent Establishment" in the 1981 U.S. Model Income Tax Treaty: Part 2", The Interwational Tax Joumal, 1989/?, p. 258

72 A.A. Skaar, op cit., n. 13, p. 487.

73 Paragraph 32 of the commentary. 


\subsubsection{The Independent Agent}

Aut. 5, para. 6 of the 1977 Model contains the provision concerning the independent agent:

"An enterprise shall not be deemed to have a permanent establishment in a Contracting State merely because it carries on business in that State through a broker, general commission agent or any other agent of an independent status, provided that such persons are acting in the ordinary course of their business."

The above-mentioned text is almost identical to the 1963 Model provision. The Commentary, however, has been extended for further definition of the independent agent. ${ }^{74}$ As in the 1963 Commentary, the 1977 Commentary also declares that an independent agent cannot constitute a permanent establishment because he represents a separate enterprise, and that the provision of para. 6 has only been inserted for the sake of clarity and emphasis. ${ }^{75}$

Paragraph 36 of the Commentary stipulates that an agent will come into the scope of Article 5, par.6, if:

"(a) he is independent of the enterprise both legally and economically, and

(b) he acts in the ordinary course of his business when acting on behalf of the enterprise."

The Commentary further elaborates on these two conditions. An example given of the legal independence is the subjection of the agent to detailed instructions or to comprehensive control. In this case the agent cannot be considered to be independent.

It almost goes without saying that a principal gives more or less detailed instructions to his, in this case, independent agent. This, however, does not make an agent dependent. The detailed instructions can be regarded as the principal's wishes. The agent provides services as good as is possible, keeping in mind the wishes of his principal. The actual activities of the agent are performed according to the skills, insights and abilities of the particular agent. The agent would be regarded as personally dependent when his obligation to obey instructions is not

74 M. Edwardes-Ker, The International Tox Treaties Service, OECD Income Article 5, p. 13.0001 (October 1990).

75 Para 35 of the Conmentary. 
merely related to specific transactions, but is of a comprehensive nature, such as it is by virtue of the power an employer has under labour laws to give orders to his employees. $^{76}$

Economic independence is described in the Commentary as bearing entrepreneurial risk by the agent. When an agent has only one principal or enterprise on whose behalf he concludes contracts, the agent is likely to be regarded as economically dependent on his one principal. However, under US and German Law, an agent can act for one principal but nevertheless be regarded as independent. ${ }^{7 /}$ This determination depends strongly on the actual facts of the case.

The basic Agency PE rule under the UN Model differs from the OECD Model. In the UN Model, Art. 5, para. 5, reads:

"Notwithstanding the provisions of paragraphs 1 and 2, where a person- other than an agent of an independent status to whom paragraph 7 applies- is acting in a Contracting State, that enterprise shall be deemed to have a permanent establishment in the firstmentioned Contracting State in respect of any activities which that person undertakes for the enterprise, if such person:

a) Has and habitually exercises in that State an authority to conclude contracts in the name of the enterprise, unless the activities of such person are limited to those mentioned in paragraph 4 which, if exercised through a fixed place of business, would not make this fixed place of business a permanent establishment under the provisions of that paragraph; or

b) Has no such authority, but habitually maintains in the first-mentioned State a stock of goods or merchandise from which he regularly delivers goods or merchandise on behalf of the enterprise."

Under section b, the delivery agent is classified as an Agency PE. This provision can be traced back to the 1929 LON report $(\$ 5.2 .3)$. The agent who maintains a stock of goods from which he regularly delivers goods or merchandise, does

76 K. Vogel, Double Taxation Comventions, (Khwer, London), p. 257.

77 J.F. Avery Jones \& D.A. Ward, 'Agents as Penmanent Establishments under the OECD Model Tax Conwention', European Toxation, May 1993, p. 171. 
constitute an Agency PE. Skaar calls this the "stock of goods test". "According to Skaar no fixed facilities, such as a storehouse or an open storage area, are required under the stock of goods test. ${ }^{79}$

The Agency PE provisions in the United Nations Double Taxation Convention concerning the independent agent differ in a few aspects from the OECD provisions. The first difference is the specific provision in the UN Model concerning the insurance agent. Art. 5, para. 6, UN Model states:

"Notwithstanding the preceding provisions of this article, an insurance enterprise of a Contracting State shall, except in regard to reinsurance, be deemed to have a permanent establishment in the other Contracting State if it collects premiums in the territory of that other State or insures risks situated therein through a person other than an agent of an independent status to whom paragraph 7 applies." $\$$

Under this provision, a permanent establishment exists if the insurer establishes its own agents or employees in the host country to collect premiums or to insure risks. ${ }^{81}$ The above-mentioned "own agent" is the regular insurance agent who could represent one or more insurance companies. If the agent is a truly independent agent, an Agency PE in this case will not be constituted according to the last part of paragraph 6 .

Further, the last sentence of Art. 5, para. 7, UN Model contains a unique condition:

"However, when the activities of such an agent (meaning the independent agent, $A . P()$ are devoted wholly or almost wholly on behalf of that enterprise, he will not be considered an agent of an independent status within the meaning of this paragraph."

The OECD Model does not contain this condition. This condition applies to all sorts of independent agents, such as the broker and commission agent. In the example of the insurance agent this will mean that the agent who represents only one insurance company will be considered to constitute an Agency PE of the

78 A.A. Skaar, op cit., n. 13, p. 529.

79 Kid, p. 530

80 United Nations Model Double Taxation Convention between Developed and Developing Countries, 1980. The text is copied from 'Teksten Internationaal \& EG belastingrecht 1999/2000'.

81 J. Huston \& L. Williarns, Permanent Establishment a planning primer, (KItwwer, Boston, 1993), p. 122. 
insurer, whether or not the agent is independent. The phrase "devoted wholly or almost wholly" leaves ample space for other factual interpretation. If an agent has for example five enterprises he represents, but one takes up a majority of his time and yields substantial profits to the agent, the agent can be regarded as an Agency PE of his major principal.

\subsection{0}

\section{SUMMARY}

The League of Nations continued the basis of German tax law, namely the replacement theory as a main principle for the taxation of foreign principals. The League of Nations 1927 Draft Convention excluded the bonafide agent of independent status from the Agency PE concept. The condition that the agent as permanent establishment would have to act habitually on behalf of the principal was laid down in the 1929 report of the LON's Fiscal Committee. The 1929 report clearly states that a broker cannot constitute an Agency PE because he merely brings parties together, he is not an agent. In line with this view, it would have been logical to exclude the broker from the Agency PE status because the broker is not an agent. The broker should have been excluded on the basis of the general Agency PE provision, and should not have been mentioned explicitly in the exemption provision regarding independent agents.

It also can be concluded that the delivery agent is to be regarded as an Agency PE. The League of Nations is clear on what they consider to be an Agency PE: namely the agent who has the authority to enter into contracts on behalf of the enterprise for which he works. In civil law countries this means that the agent concludes contracts in the name of the principal. The use of the term "duly accredited agent" implies this very point, and also indicates that the sending of invoices in the name of the principal by the agent, constitutes an Agency PE.

In the 1929 report the confusion started concerning the term "commission agent". The fiscal committee translated the English term commission agent into the French term commissionnaire. By also referring to the French agent a la commission, the confusion increased. The common law commission agent is the counterpart of the French agent à la commission. However, from this point onwards, the term "commission agent" was translated by the civil law term commissionnaire. I proved in paragraph 7.2.3. (and in Chapter II of this study) that the common law definition for "commission agent" is completely different than the civil law definition for commissionnaire. Further, the League of Nations is not explicit 
whether an independent agent who concludes contracts in the name of the principal is to be classified as an Agency PE.

The Mexico/London Model Conventions supplied the basis for the current Agency PE provisions in the OECD Model. In these conventions the broker and commission agent were treated as one group of agents of a genuinely independent status. This starting point, in my view, is a false doctrine. The broker is not an agent; he does not conclude contracts, and he should therefore be excluded from the Agency PE status on the basis of the general Agency provision, as stated in, for example, Art. 5(5) OECD Model. This is on the condition that the broker acts in the normal course of his business, meaning that he would not conclude contracts in the name of a principal and he would work for any number of clients. The specific condition concerning the independent agent "acting in the ordinary course of their business" was added to the Agency PE provisions due to the 1958 report of the Fiscal Committee of the OEEC. An important observation is that the OEEC considered a commission agent, who acts as a permanent agent having an authority to conclude contracts, to act outside the normal course of his own trade and thus constitutes an Agency PE.

In the 1963 Model a clear reference is made to another important aspect concerning the Agency PE, namely the fact that the agent as permanent establishment binds the foreign principle by concluding contracts. It's evident that acting "in the name of" the principal is a condition that leads to confusion among common law practitioners. Therefore, this element of the Agency PE concept is added on the basis of the civil law perception of agencies. 



\section{Current Agency PE Definition}

\subsection{INTRODUCTION}

The 1997 OECD Model contains an Agency PE provision exactly the same as the provision from the earlier 1977 OECD Model. During the period of 1992-1997 several paragraphs of the commentary were renumbered and amended. One significant paragraph of the commentary on the Agency PE was amended on 31 March 1994. This particular alteration will be discussed in one of the following paragraphs. The current Agency PE definition will be analysed on the basis of the analyses in the previous chapters. All the specific conditions in Art. 5, para. 5 and 6 , of the 1997 OECD Model will be discussed.

8.2.

ARTICLE 5, PARAGRAPH 5, OECD MODEL

\subsubsection{Treaty Text}

"Notwithstanding the provisions of paragraphs 1 and 2, where a person -other than an agent of an independent status to whom paragraph 6 applies- is acting on behalf of an enterprise and has, and habitually exercises, in a Contracting State an authority to conclude contracts in the name of the enterprise, that enterprise shall be deemed to have a permanent establishment in that State in respect of any activities which that person undertakes for the enterprise, unless the activities of such person are limited to those mentioned in paragraph 4 which, if exercised through a fixed place of business, would not make this fixed place of business a permanent establishment under the provisions of that paragraph."

\subsubsection{Paragraph 5 in Relation to Paragraphs 1 and 2}

The text of para. 5 starts off with: "Notwithstanding the provisions of paragraphs 1 and 2". If a foreign enterprise has a physical PE according to paragraphs 1 and 2, there would be no reason for application of the Agency PE clause of para. 5. I think that also para. 3 should be mentioned in the opening phrase of para. 5, 
because if, for example, a construction PE is present according to the conditions of para. 3, again, application of para. 5 would not be called for. Para. 31 of the OECD Commentary states:

"It is a generally accepted principle that an enterprise should be treated as having a permanent establishment in a State if there is under certain conditions a person acting for it, even though the enterprise may not have a fixed place of business in that State within the meaning of paragraphs 1 and $2 . "$

The reason for the fact that para. 3 is not mentioned in the opening phrase of para. 5 , could be because in the 1963 OECD Model the construction PE was included in para. 2. After the 1963 Model, the construction PE was transferred to a separate paragraph (para. 3).' The construction PE provision stipulates that a construction or building site which lasts more than twelve months, constitutes a PE. Because in this case there is a fixed place of business (the actual construction or building site), para. 3 should be mentioned in the opening phrase of para. 5 .

Before considering an Agency PE, two questions should be answered negatively, namely: (1) does the foreign enterprise has a fixed place of business in the other state?, and (2) does the foreign enterprise has a building site or construction or installation project with a duration of more than twelve months?

If a construction PE (referring to the second question) is present, the foreign enterprise may be taxed on its profits generated through the construction PE and there is no need to analyse whether or not an Agency PE is present.

In many Dutch tax treaties, like e.g. the 1992 Dutch - US double taxation convention $^{2}$, a construction PE is assumed if the building site or construction or installation project lasts more than twelve months. This means that, if such a project lasts less than twelve months, a construction PE is not present. In this case a PE, nevertheless, can still be deemed to exist if an Agency PE is present. It could be e.g. that on the construction project an employee of the foreign company has the authority to conclude contracts in the name of and on behalf of the foreign enterprise and habitually exercises that authority. If the contracts which the employee concludes concerns the core activities of the foreign enterprise, an Agency PE is deemed to exist although the project lasts less than twelve months. The employee could e.g. conclude contracts concerning assignments for new construction projects.

1 K. Vogel, Klans Yogel on double faxation conventions, 3rd. ed., (Kluwer, Boston, 1998), p. 305.

2 Article 5, para. 3 . 
If, however, the contracts can be considered to be of a preparatory of auxiliary nature, according to Article 5, para. 4, OECD Model, an Agency PE does not exist. This could be if, for example, the authorised employee hires extra personnel locally to work on the construction project.

\subsubsection{A Person other than an Agent of an Independent Status}

Persons who can create an Agency PE, can be either individuals or companies. ${ }^{3}$ Art. 3, para. I(a) defines persons as "any other body of persons". In the commentary it is mentioned that the term "person" includes any entity that (although not incorporated) is treated as a body corporate for tax purposes. ${ }^{4}$ So, for example, a foundation could be regarded as a "person", and could therefore be regarded as an agent when applying Art. 5 of the OECD Model. The OECD Commentary names these persons as "dependent agents".

One could argue that paragraph 6 comes after paragraph 5 , and therefore the correct analytical order would be to first consider if the agent meets the conditions laid down in paragraph 5 and than, if those conditions are not met, analyse if the agent is an independent agent according to paragraph 6 . This would be an illogical approach because if the agent does not meet the paragraph 5 conditions an Agency $\mathrm{PE}$ is never present, even if the agent is not an independent agent according to paragraph 6.

The text of paragraph gives the solution for the correct analytical order by stating: "...where a person- other than an agent of an independent status to whom paragraph 6 applies -...".

If there is an agent, before analysing if this agent meets the paragraph 5 conditions, one should first analyse if the agent is an independent agent according to paragraph 6. If this is the case, there is no need to analyse paragraph 5 , because the agent does not constitute an Agency PE on the basis of paragraph 6. On the other hand, if the agent does not meet the conditions of paragraph 6 , because perhaps he is an independent agent who does not act in the ordinary course of his business, paragraph 5 should than determine if that agent constitutes an Agency PE.

3 Para. 32 OECD Commentary on Article 5.

4 Para. 2 OECD Commentary on Article 3. 


\subsubsection{Acting on Behalf of an Enterprise}

\subsubsection{General Observations}

Art. 5, para. 5, lists the first essential element of the Agency PE, namely that a person must be acting "on behalf of an enterprise". This obviously excludes the person who works for his own enterprise. It means that the economic risk of the business contract concluded by the agent must fully lie with the principal. The agent receives his commission or remuneration and the principal receives the profits. This condition is based on the replacement theory ${ }^{5}$ : an entrepreneur can conduct his business himself, but can, if he so wishes, be replaced by an agent. The agent performs services on behalf of the entrepreneur being his principal. This condition of the Agency PE definition forms the basis of the assumption that the person must be an agent in accordance with Art. 5, para. 5, OECD Model.

\subsubsection{The Entrepreneur is Both Principal and Agent}

The entrepreneur could in fact act as his own agent. In absence of a fixed place of business, the question could then arise if the entrepreneur could constitute an Agency PE on his own behalf. There are a few United States rulings which give support to the concept that an individual principal can be his own permanent establishment given his substantial trading presence in the host country without regard to the existence of a fixed-place-of-business or dependent-agency permanent establishment. ${ }^{6}$

In a US 1981 private letter nuling ${ }^{7}$, the issue was if the filing of Form 001, a form denying the existence of a permanent establishment, by nonresident alien race horse owners, did relieve the US withholding agent from the liability to withhold tax on winners' purses. The US withholding agent was a US corporation that operated a harness racing track. The ruling states:

'The Service will consider, in part, activities such as an owner or agent, with general contracting authority, concluding contracts within the United States with respect to the entry of horses in a race, the stabling or training of the horse and his length of stay within the United States, as

5 See para. 3.2

6 J. Huston \& L. Williams, Pernonen Establishment: A Planner Primer, (Kluwer, Boston, 1993), p. 124

7 U.S./Canada Letter Ruling 81-38-020, Edwardes/Ker, OECD Income Article 5, p. 147. 
factors that may constitute the nonresident alien owners having a permanent establishment in the United States."

Here, the dictum states, "Activities such as an owner or agent." The term "or" implies that it makes no difference if the owner himself or his agent has a general authority to conclude contracts.

Meanwhile, in a 1956 United States Revenue Ruling a sole proprietor who demonstrated logging equipment which he manufactures, although he had no fixed place of business, was considered to have a PE in the US The Ruling states:

"Although the enterprise under consideration has no warehouse or other type of building in the U.S. in which or from which it is conducted, the equipment involved is logging equipment which is necessarily demonstrated in particular forest areas and was brought here for purposes of such demonstration with the expectation that orders would be obtained for such equipment."

This ruling seems to be prompted from a view to tax the profits of a foreign entrepreneur at any price. The foreign entrepreneur had no physical permanent establishment in the U.S., and could therefore only be taxed if an Agency PE could be discerned. The ruling clearly refers to the Agency PE in the last part of the quoted dictum, "with the expectation that orders would be obtained".

So, to the contrary, if no expectation of obtaining orders is present, an Agency PE could not be discerned. The IRS standpoint on this ruling is contrary to the essence of the tax-treaty agency clause. An agent must actually and frequently exercise his contracting authority. A mere expectation is not enough. If, for example, an enterprise engages an agent who is sent abroad with the mission to sell the enterprise's products, but in fact could not sell one single product, then no contracts were concluded, and determining that an Agency PE is present is not justified. The agent did not exercise the needed authority, according to the Agency PE treaty provision (an Art. 5, para. 5, OECD Model provision).

In a 1990 German Bundesfinanzhof ruling, a German independent sales representative claimed to be his own agent in the former East German Republic (DDR). The court, however, stated that an agency relationship requires that the agent acts instead of his principal within the framework of the latter company, thus

8 U.S.Switzerland Rewenue Ruling 56-165 (1956-1 CB 849), Edwardes-Ker, OECD Income Article 5, p. 70 . 
implying two different persons. The legal agency relationship departs from indeed two different persons, namely the principal and the agent. If the principal acts as an agent, he in fact represents himself, which makes an agency relationship redundant. German domestic law (Art. 13 General Fiscal Law) defines an agent as a person who conducts business for an enterprise, acts durable and permanently and must comply with the instructions of the principal. The last part of the definition contains the view that there should be two different persons. In conclusion, on the basis of the agency concept which demands two separate persons to constitute that legal relationship (namely a principal and an agent), if an entrepreneur acts as his own agent, an Agency PE cannot be established. Because the Agency PE concept is based upon the legal concept of agency, an entrepreneur cannot be his own agent. An agent acts in stead of the principal (or entrepreneur). If the principal concludes a contract himself, there is no agency present, and this will therefore not lead to an Agency PE.

\subsubsection{Fixed Place of Business}

From paragraph 31 of the OECD commentary it can be concluded that an enterprise could have an Agency PE, although the enterprise may not have a fixed place of business within the parameters of Art. 5, paragraphs 1 and 2. Absence of the fixed place of business requirement also applies to the agent, meaning the agent can be resident of state $A$ but works as an agent in state $B$, and could in state $\mathrm{B}$ constitute an Agency PE on behalf of an enterprise of state A (for example).

In a German Bundesfinanzhof ruling of 1974, a Danish company operated a restaurant on board a merchant vessel of German registry which operated between Germany and Sweden. Although the ship itself would obviously not qualify as a fixed place of business, the employee who worked in the restaurant selling food and beverages to customers could qualify as an Agency PE, if he had the authority to conclude contracts. In this case a permanent establishment was determined. ${ }^{9}$ Absence of a fixed place of business does not stand in the way of discerning an Agency PE.

In another example, a Swiss management consultancy firm rendered services to German companies. The Swiss director sometimes concluded contracts with German companies, but in other instances, the contracts were concluded by consultants chosen by the Swiss company for the job. These consultants usually worked at the offices of the German companies. The German tax authorities argued that the Swiss company had several permanent establishments in Germany, and they based their conclusion on two arguments:

9 BFH February 13, 1974, BStBI. III. 361, 1974, IR $219 / 71$ 
1. the offices of German companies were at the disposition of the Swiss company, therefore constituting a fixed place of business, or

2. the management consultants were dependent agents.

The German court (Finanzgericht) held, that the fact that a consultant has an office at his disposal, did not qualify as a fixed place of business within the meaning of provisions comparable to Article 5, para. 1 of the OECD 1963 draft. The GermanSwiss treaty had ended in 1971, and the court therefore referred to the 1963 OECD Model. The second argument of the German tax authorities was also rejected by the court, the consultants in this case were freelance persons rendering independent personal services and did not habitually conclude contracts. ${ }^{10}$ The temporary working place of the agent (an office of a company where the agent temporarily works) is not a fixed place of business which can be attributed to the foreign enterprise, according to the German court. Where the 1963 OECD Commentary did not specifically address this issue, the current OECD commentary on Article 5 states in paragraph 4 :

"A place of business may also exist where no premises are available or required for carrying on the business of the enterprise and it simply has a certain amount of space at its disposal. Again the place of business may be situated in the business facilities of another enterprise. This may be the case for instance where the foreign enterprise has at its constant disposal certain premises or a part thereof owned by the other enterprise."

According to this view a fixed place of business could be present if, for example, an agent has certain (office) space at its disposal. But, the commentary adds, this space must be at the constant disposal of the agent. If a company does not designate a certain work space or office permanently to the agent, no fixed place of business is present.

In another ruling in 1992, a German court decided that a Dutch butcher who worked for several German abattoirs was not deemed to have a German PE. He used space in the abattoirs, but according to the court, had no legal right to use the abattoir facilities which had been made available to him. ${ }^{11}$ This, in my view, is a valuable argument; an agent must have a legal right, created either by means of hiring or leasing certain working space, to use certain premises in order to establish a fixed place of business.

10. Lower Saxony FG/1, July 4, 1991 (No. VI 480/89; 1991 RiW 1055), Edwardes-Ker, p. 46.5.

11 Dusseldorf FG, June 24, 1992 (Finanzgericht: $13 \mathrm{~K} 56088 \mathrm{E} ; 1993 \mathrm{EFG} 42$ ), Edwardes-Ker, p. 46.5002 . 


\subsubsection{A General PE Combined with an Agency PE}

The situation could arise that an enterprise has a fixed place of business which qualifies as a general PE, according to an Article 5, para. 1 of the OECD Modellike provision, and also engages a dependent agent in the same state (as the fixed place of business) who has the proper authority according to Article 5, para. 5. Because Article 5, para. 5 of the OECD Model has a supplementary function, it provides for an alternative test to determine whether an enterprise has a permanent establishment in a state ${ }^{12}$, leading to a treatment of the general PE including the Agency PE's profits. Because the main purpose of the PE concept is determining the level of commercial activities of a foreign company justifying taxation of the PE's state on the profits generated through the PE, basically the following conclusion should be drawn: if a general PE and an Agency PE exist, both profits (created by the general PE and Agency PE) should be treated as one. Even if the connection between the general PE and Agency PE could be very thin, the main objective should be to determine if the foreign enterprise should be taxed by the PE's state on its profits. If a PE is present, the PE's state has the right to tax the PE's profits.

If, for example, a foreign enterprise owns a factory ${ }^{13}$ in the Netherlands but also engages an agent who is authorised to conclude contracts in the name of the foreign enterprise, the foreign enterprise is liable to Dutch taxes. The factory constitutes a PE, and the agent (if considered separately) constitutes an Agency $\mathrm{PE}$. The profits generated through the agent will be subjected to Dutch taxes, whether or not the agent constitutes an Agency PE, because of the presence of the general PE (in this case the factory). Both the factories' profits and the agents' profits will be taxed. The appropriate question, however, is how much of those profits should be taxed by the Netherlands. I think that the allocation method in this case could differ. The factories' profits could demand a different allocation method than in case of the agent's profits.

\subsubsection{The Agent's Authority}

Paragraph 5 stipulates that the agent must have an authority to conclude contracts in the name of the enterprise. An agent can receive the proper authority from his principal in a number of ways. In civil law and common law jurisdictions, usually the authority is given to an agent by means of an agreement with the principal. In

12 K. Vogel, op cit., n. 1, p. 330.

13 According to para. 2 of the OECD Commentary on Article 5 , para. 1, the factory must have a productive charncter, namely, it must contribute to the profits of the enterprise. 
the Netherlands this agreement would be called a volmacht. ${ }^{14}$ Its counterpart in common law jurisdictions would be called "express actual authority". 15 A principal, in short, can give authority by means of a written agreement.

I agree with Skaar that a crucial question concerns what circumstances will qualify as an authorisation to act on behalf of somebody else. ${ }^{16}$ As Persico pointed out ${ }^{17}$, Article 3, para. 2, OECD Model, should be applied because the term "authority" is not defined in the treaty, and therefore it should be defined under the law of that State which applies the treaty. If the principal's State is e.g. a common law jurisdiction and the agent's State a civil law jurisdiction, it could cause problems in interpreting the meaning of the term "authority".

I think that these interpretation problems could be solved on the basis of international private law. In contracts concluded between parties from different countries, its common to contain a provision stipulating which law governs the contract. If this choice is made, both jurisdictions will respect this choice on the basis of rules on international private law.

International private law in that case, overrules national law and should be applied. I think there is no reason to excluded international private law from Article 3, para. 2 OECD Model, meaning, that if e.g. in the contract between a principal and an agent, the law of the agent's State rules the contract, the latter jurisdiction has to be applied in analysing if the agent has the proper authority according to Article 5, para. 5, OECD Model. ${ }^{18}$

If there is no provision in the contract between the principal and the agent determining which law must be applied to the contract, the authority must be judged according to internal domestic law. This would obviously imply that both laws will be applied, namely the law of the principal's State if the tax position of the principal is considered by the residence State, and the law of the agent's State if the tax authorities of that source State consider the tax liability of the foreign principal.

14 This volmach gives the agent the necessary legal authority to conclude contracts in the name of the principal, according to Article 60, para.1, Dutch Civil Code.

15 See paragraph 2.2.2.

16 A.A. Skaar, op cit., n. 15, p. 490.

17 G. Persico, Agency Permanent Establishment under Article 5 of the OECD Model Convention, Intertax, vol. 28 , issue 2 , p. 69.

18. On the assumption that the treaty between both Contracting States is based on the OECD Model. 
As the OECD Commentary stipulates, agents must conclude contracts binding the enterprise (i.e. the principal). ${ }^{19}$ This implies that the agent must have the appropriate legal authority, for example by means of a mandate or volmacht, to conclude contracts which are legally binding on the foreign enterprise. This authority must obviously be exercised habitually.

Skaar concludes that "authority" in terms of tax treaties exists if the principal has put the agent in a position where a bona fide third party is justified in believing that the agent's actions are based on an authorisation and thus creates an obligation for the principal. ${ }^{20}$ This standpoint refers to external authority. Internal authority refers to the authorisation between the principal and the agent. External authority relates to the authorisation between the principal and the third party. ${ }^{21}$ I agree with Skaar that the external relationship is decisive in determining if the agent has the authority, required in para. 5 , to bind the principal. The internal relationship would be less appropriate to serve as a decisive factor in this "authority issue", because most domestic legislation regarding agencies - common law as well as civil law has provisions which enable the principal to, afterwards, validate the originally unauthorised action of its agent.

The OECD commentary, when explaining that it wouldn't have been wise to arrange for any dependent person to be regarded as an Agency PE, makes an interesting remark:

"Such treatment (meaning treatment as an Agency PE, $A P D$ ) is to be limited to persons who in view of the scope of their authority or the nature of their activity involve the enterprise to a particular extent in business activities in the State concerned., 22

This is the case when the agent concludes contracts binding the foreign principal. These remarks seems to indicate that next to the agent's authority, another element could be important when deciding if an agent constitutes an Agency PE of its principal, namely "the nature of their activity". This could imply that, although an agent perhaps doesn't have the proper legal authority to conclude contracts, he could still be active in such a way, that the "nature of his activity" could lead the conclusion that he should be regarded to constitute an Agency PE on behalf of his principal. In the next paragraphs, I will therefore analyse if this standpoint can be upheld.

19 See para. 32, OECD Commentary on Article 5

20 A.A. Skaar, op cit, n. 15, p. 502

21 H.L. B. Verhagen, Agency in Private International Law, p. 305.

22 Para. 32 OECD Conmentary on Article 5. 


\subsubsection{The Scope of the Agent's Authority}

A key element in the Agency PE definition is the agent"s "authority to conclude contracts". The authority must have authority which legally enables the agent to conclude contracts. The term "authority" is not explicitly explained in the OECD Model, according to Art. 3, para. 2: "...any term not defined therein shall, unless the context otherwise requires, have the meaning that it has at that time under the law of that State...". As a result, the authority is a restricted authority because Art. 5 , para. 5 only applies to an authority to conclude contracts. Because the term "authority" is not defined in the OECD Model, a second restriction can be recognised, the fact that in civil law countries the agent would have to conclude contracts literally "in the name of" the foreign enterprise, whereas in common law countries ${ }^{23}$ the agent would have to conclude contracts which are legally binding the foreign enterprise.

According to Art. 3, para. 2 the context of Article 5, para. 5 OECD Model could require a different interpretation of the term authority. The context of Art. 5, para. 5 is taxing profits generated by a dependent agent of a foreign enterprise. According to Vogel, the question whether an agent has an authority to conclude contracts within the meaning of treaty law, must be decided not only with reference to private law but must also take into consideration the actual behaviour of the contracting parties. An approach relying solely on aspects of private law would make it easily possible to prevent an agent from being deemed a permanent establishment even when he is engaged most intensively in the enterprise's business. ${ }^{24}$

This would be contrary to the context of Art. 5, para. 5 OECD Model. The way to prevent the Agency PE status would be to avoid meeting the general agency requirements. A civil llaw agent would simply never conclude contracts "in the name of" the principal. This could mean, either concluding contracts in his own name, or let the principal himself conclude the actual contracts. As I've pointed out earlier, the OECD Commentary, in my view, leaves the possibility open that an agent- because of the nature of his activities-could qualify as an Agency PE. If an agent does not have the actual authority to conclude contracts, but has the authority to involve the principal "to a particular extent in business activities in the State concerned", he could qualify as an Agency PE. This could apply to an agent who has extensive powers to negotiate contracts up to the point of actually concluding

23 Please refer to Chapter II of this study.

24 K. Vogel, op cit, n. 1, p. 331. 
contracts. One could argue that if an agent has sufficient authority to negotiate contracts on behalf of his principal, the principal accepts the fact that his agent is in the process of binding him to the contract. Also, according to private law, during contract negotiations there could be a kind of "point of no return", meaning that the contract is concluded, although the actual contract is not signed by both parties. Terminating contract negotiations could, in some instances, imply that the party that terminated the negotiations could be liable to pay damages incurred by the other contracting party. ${ }^{25}$ According to Dutch law, if negotiators (for example the agent and the third party) reached full agreement on the terms of the contract, but a reservation is made regarding approval by the agent's principal, the contract is concluded containing a suspended condition. ${ }^{26}$ If the principal approves, the contract can be executed. But more importantly, it is recognised that the agent concluded a binding contract.

\subsubsection{The Agent's Activities}

\subsubsection{Introduction}

Before an agent has sold the first product of his principal, performed the first service or concluded the first contract, many activities by the agent would have been undertaken. In the following paragraphs I will discuss these preliminary activities and analyse if these single activities fall within the definition of Art. 5 , para. 5 OECD Model.

\subsubsection{Advertising and Promotional Activities}

Before an enterprise engages an agent who will actively sell its products, an enterprise could decide to advertise in the agent's state in order to find out if there is a market for its products. This could mean, for example, advertising via the written media or television. If an enterprise engages an agent whose task it is to advertise in the local media, the question could arise if the enterprise's agent constitutes an Agency PE on behalf of the (foreign) enterprise.

The agent could also, in fact, have the authority to conclude contracts in the name of the enterprise. These contracts would be advertising contracts.

25 H. J. de Kluiver, Onderhandelen en privatrecht (Negotiating and private law), dissertation, (Kluwer, Deventer, 1992), p. 334.

26 W.I. Slagter, Het afbreken van onderhandelingen (Terminating contract negotiations), published in Intemationale Commerciele Contracten, M.J.G.P. Kaplan (editor), (Academic Service, Schoonhoven, 1993), p. 82. 
According to the OECD commentary, the agent's authority to conclude contracts must cover contracts relating to operations which constitute the business proper of the enterprise. ${ }^{27}$ Concluding advertising contracts would, at least if the enterprise itself is not active in the advertising business, not relate to the core business of the enterprise. Therefore, an advertising agent would not be deemed to constitute an Agency PE on behalf of his principal.

The last part of Article 5, para. 5 OECD Model states that even though a dependent agent has, and habitually exercises, the authority to conclude contracts in the name of his principal, he still would not be regarded as an Agency PE if "the activities of such person are limited to those mentioned in para. 4 which, if exercised through a fixed place of business, would not make this fixed place of business a permanent establishment under the provisions of that paragraph". Meanwhile, Article 5, para. 4 OECD Model lists a number of business activities which are not treated as a permanent establishment, because they could generally be considered to be preparatory or auxiliary activities. This means that an agent who performs duties of a preparatory or auxiliary nature, is excluded from the Agency PE status according Article 5, para. 5 OECD Model. In paragraph 23 of the OECD Commentary on Article 5, para. 4, a fixed place of business solely for the purpose of advertising, if such activities have a preparatory or auxiliary character, is treated as an exception to the general PE definition of Article 5, para. 1 OECD Model. These arguments could also be applied to the agent who undertakes promotional activities, like for example, visiting trade fairs or exhibitions, to promote the principals products or services. If, however, the promoting agent also has the authority to conclude contracts in the name of the principal, relating to the core business of the principal, and also exercises this authority, the agent could qualify according to Article 5, para. 5 OECD Model. But what if the majority of the agents activities will qualify as activities of a preparatory or auxiliary character, and a small part of the activities of the agent could be regarded as activities according to Article 5, para. 5 OECD Model? This issue of mixed activities will be analysed in the next paragraph.

\subsubsection{Mixed Activities}

It could very well be that an agent performs, what I would like to call, Article 5, para. 5 activities and those not covered by the article. An agent performs Article 5 , para. 5 , activities if he concludes contracts in the name of the principal, or

27 Paragraph 33. OECD Commentary on Article 5, paragraph 5. 
concludes contracts binding the principal. Activities which are not covered by the article are, for example, activities of a preparatory or auxiliary character. Activities covered by Article 5, para. 4, OECD Model.

If an agent performs services which can be regarded as Article 5, para. 5 activities, the principal is regarded as having an Agency PE. Does this imply that all the agent's activities, including the Article 5, para. 4. OECD Model activities, should be allocated to the Agency PE?

In a Dutch supreme court ruling of $1995^{28}$, a Dutch insurance agent acted on behalf of an English property insurance company in two different ways, as a legal representative and as an authorised agent. These are two different kinds of insurance agents, as defined by Dutch law. Acting as a legal representative was not considered to be an Agency PE activity, whereas acting as an authorised agent did meet the Article 5, para. 5 OECD Model requirements. The Dutch tax authorities claimed that the overall activities of the Dutch insurance agent should be divided accordingly. This would lead to partial taxation of the insurance agent's activities on behalf of the UK company. However, the Dutch Supreme Court didn't agree with this standpoint because, as they reasoned, it was not just to treat an agent who on the whole could be regarded as an independent agent, partially as a dependent agent.

Vogel states that if an agent has a restricted authority to specific lines of business within the enterprise"s overall business activities, the permanent establishment's activities would have to be restricted to business contracted by the agent, and any direct transaction by the enterprise would have to be disregarcled in connection with the permanent establishment's tax liability. ${ }^{29}$ Vogel has the situation in mind that next to the agent's activities, the principal himself undertakes some sort of business activities in the agent's state. If, for example, the agent has a restricted authority to conclude contracts up to a certain quantity or value, and contracts above the agent's limit are negotiated and concluded by the principal himself, the profits regarding the latter contracts cannot be allocated to the Agency PE.

This Dutch court case from $1995^{30}$ deals with another situation, namely an agent who performs duties or services on behalf of one and the same principal, but some of these duties or services qualify as Art. 5, para. 5 OECD Model activities, namely concluding contracts in the name of the principal, and some activities do not qualify. The Dutch supreme court made an overall assessment:

28 Dutch Supreme Court June 28, 1995, BNB 1996/108c.

29 K. Vogel, op cit., n. 1, p. 331.

30 Dutch Supreme Court June 28, 1995, BNB 1996/108c. 
is the agent in question a dependent or independent agent? In this case the agent was considered to be an independent agent. But what if the agent, on an overall basis, could be regarded as a dependent agent? In this case, should all activities be allocated to the then deemed Agency PE? The OECD Commentary is clear about this issue:

"Where the requirements set out in paragraph 5 are met, a permanent establishment of the enterprise exists to the extent that the person acts for the latter, i.e. not only to the extent that such a person exercises the authority to conclude contracts in the name of the enterprise., ${ }^{, 31}$

This view seems to indicate that the "concluding contracts in the name of the principal" condition has a threshold function, and obviously, therefore also the other Article 5, para. 5 OECD Model conditions. If an agent qualifies, all the actions the agents performs on behalf of the principal will be included in the Agency PE, according to para. 34 OECD Commentary.

If the agent acts on behalf of his principal, the profits which could arise from these actions are allocated to the Agency PE. If, for example, an agent not only concludes binding contracts on behalf of the principal, but also acts as a purchasing agent (Article 5, para. 4 (d), OECD Model), both activities will be included in the Agency PE profits. The last part of Article 5, para. 5, is in line with this conclusion, because it states there that an agent will be excluded from para. 5 if "the activities of such person are limited to those mentioned in paragraph 4". So, if an agent concludes not only para. 4 activities, but also para. 5 activities, the para. 4 exemption rule cannot be applied.

\subsubsection{A Principal with a PE and an Agency PE in the Same State}

It could occur that a foreign principal has a factory in a certain state but also an agent who concludes contracts on his behalf in the same state. The factory is a fixed place of business according to Article 5, para. $1 \& 2$ OECD Model and therefore constitutes a PE on behall of the foreign principal. The agent who concludes contracts in the name of the principal and habitually exercises that authority constitutes an Agency PE on behalf of his foreign principal. 
According to paragraph 35 of the OECD Commentary, Article 5, para. 5 OECD Model simply provides an allemative test determining whether an enterprise has a PE in a state. If it can be shown that the enterprise has a $\mathrm{PE}$ within the meaning of paragraphs 1 and 2, it is not necessary to show that the person in charge is one who would fall under paragraph 5 . In my example, this view refers to the person who runs the factory. But what if there is not a close connection between the factory and the agent? My opinion is that, in light of the purpose of the PE concept, it can be said that the foreign principal (or enterprise) is engaged in the PE state in such a way that that the state has the right to impose taxes on the profits which the principal derives from that state, from both the PE and Agency $\mathrm{PE}$.

The principal has one PE, because one PE is sufficient in giving the PE's state the right to levy taxes. The one PE consists of two different activities, that of the factory and the agency.

\subsubsection{The Sub-Agent}

If a fully authorised agent, meaning an agent having the legal authority to conclude contracts in the name of the principal or legally binding the principal, engages another agent to perform certain duties he himself should perform under the contract between himself and the principal, it could be determined that the foreign principal has an agent and a sub-agent. Legally, it seems obvious that the principal is obliged to give his consent to the involvement of the sub-agent. If the consent is given, the principal has two agents, which, in my opinion, are treated as one Agency PE. ${ }^{32}$

Problems could arise if the sub-agent himself, for example, does not have the authority to conclude contracts in the name of the principal. He would therefore not qualify as an Agency PE. Paragraph 34 of the OECD Commentary states that, if the agent is considered to constitute an Agency PE, all the acts for the principal will be included in the Agency PE. The hiring of the sub-agent, in my view, is an action of the agent on behalf of the principal and therefore should be included in the Agency PE profits.

\subsubsection{Preparatory or Auxiliary Activities}

According to Art. 5, para. 4 OECD Model, the maintenance of a fixed place of business solely for the purpose of purchasing goods or merchandise or for collecting information for the enterprise will not be regarded as a PE. Art. 5,

32 Provided the conditions of Art. 5 , para. 5 OECD Model are met. 
para. 5 OECD Model excludes from that paragraph the agent whose activities are limited to those mentioned in paragraph 4 which, if exercised through a fixed place of business, would not make this fixed place of business a PE.

This means that agents who solely undertake activities which can be defined as preparatory and auxiliary activities will not be regarded as an Agency PE. This includes the delivery agent, purchasing agent, the information collecting agency (like for example a newspaper bureau) and advertising agent. It is recognised that such a place of business may well contribute to the productivity of the enterprise, but the services it performs are so remote from the actual realisation of profits that it is difficult to allocate any profit to the fixed place of business in question. ${ }^{33}$

\subsubsection{After-Sale Services}

Paragraph 25 of the OECD commentary on Article 5, para. 4 stipulates that an after-sale organisation performs an essential and significant part of the services of an enterprise vis-à-vis its customers, activities which are not merely auxiliary ones. An agent performing after-sales services could on this basis not be exempted from an Agency PE status if he concludes binding contracts regarding after-sales services.

A 1992 French court ruling ${ }^{34}$ had the same outcome. A Swiss company exported machine tools which it manufactured to France. It had a warehouse in France, the personnel of which assured an after-sales service to fulfil guarantees which these tools carried. However, the personnel fulfilled orders for spare parts and mended tools, without referring these orders of business back to their head office in Switzerland; they invoiced according to a scale established by the head office. The court ruled that the French office possessed a certain autonomy regarding its relations with clients. The agents who were working there habitually exercised powers restricted to the aforementioned operations of sales and rendering of services, but represented an important tumover. This was not limited to the purchase of merchandise for the Swiss company and permitted them to conclude contracts in the home of the office. On these grounds the court ruled that the French office constituted a PE. In this case the agents did not exclusively perform services of an auxiliary nature. They also fulfilled orders for spare parts. They had the authority to conclude contracts in the name of the Swiss company. In view of

33 Paragraph 23 OECD Commentary on Article 5, paragraph 4.

34 Cour Administrative d'Appel Lyon, no. 92-133, December 9, 1992, Edwardes-Ker, International Tax Treaties Service, p. 35.5005. 
the important turnover these sales generated, an (Agency) PE status is in my view justified. The sales activities obviously exceeded the pure after-sale activities. If agents, on the other hand, would only perform after-sale services, and the concluding of sales contracts would be a minor part of the overall activities, Agency PE status is in my view not called for.

\subsubsection{Soliciting and Concluding of Contracts}

Soliciting of orders literally means inviting a party to a business transaction. ${ }^{35}$ Soliciting orders at fixed prices subject to substantive home office approval could lead to avoidance of the Agency PE status, according to Huston and Williams. ${ }^{36}$ This means for example that the home office can alter the terms of the offer. So the essence of this issue is the role or involvement of the principal. If an agent has a fixed price list and draws up an order form, he invites his customer and his principal to conclude a contract. If the agent draws up an order form it merely means that the customer and agent agree on the terms of the specific order. The order, however, can not be regarded as a legal contract. The order form is then forwarded to the principal. If the principal has the power, and does exercise that power, to change the terms of the order or reject the order, the principal has the power to conclude contracts, not its agent. The agent, in this case, does not involve the principal in business transactions in such a way that the principal can be taxed based on the activities of his agent. The agent in this case would, in my view, not qualify as an Agency PE. In a Canadian court case it was held that an agent whose task was to interview prospective customers and to notify their requirements to the company"s office in the US was not considered to constitute an Agency PE. In this case the contracts were negotiated and concluded by the US resident employees of the company. ${ }^{37}$

Skaar states that a denial of an Agency PE must also apply to activities which include a limited authority to commit the principal, for instance keeping and running an office for the principal, collecting outstanding claims, etc., as long as it does not include the power to conclude business agreements. ${ }^{38}$ Skaar focuses primarily on the concluding of the actual contracts. Meanwhile, Avery Jones and Ward state that, concerning the authority to conclude contracts, one should look at

35 According to Ballentine's Law Dictionary.

36 J. Hustond L. Williams, Permanent Establishments - a plamning primer, (Kluwer, Boston, 1993), p. 83.

37 American Wheelabrator and Equipment Corporation v. M.N.R. 4 Canadian Tax App. Bd. 345, 1951 .

38 A.A. Skaar, op cit, n. 15, p. 492. 
the position as a matter of substance rather than the mere form. ${ }^{39}$ I think that the involvement of the principal is the decisive factor. If the principal is bound to the contract or order concluded by its agent, the agent exercised the necessary authority required according to Art. 5 para. 5, OECO Model. If the agent officially has no authority to concluded contracts, but he negotiates all the terms of the contract, and the official approval of the principal is only pro forma, the agent, in my view, has the necessary authority according to paragraph 5. If, on the other hand, the approval of the principal (or head office) certainly is not pro forma, the agent does not qualify. This would, however, implicate that the customer, or third party, should be aware of the fact that the order or contract he concluded with the agent is only provisionally, and that only if the principal approves of the contract, the latter is bound and the contract is final.

\section{Paragraph 33 of the OECD Commentary concludes likewise:}

"A person who is authorised to negotiate all elements and details of a contract in a way binding on the enterprise can be said to exercise this authority "in that State", even if the contract is signed by another person in the State in which the enterprise is situated."

The Commentary relates to a situation where the approval of the principal is merely a pro forma action. Skaar concludes that an Agency PE should be attributed to the country where the major part of the business activities are performed. Normally this will be the State where the contract is negotiated. ${ }^{40}$ A view which would not necessarily be contradictory to my view which emphasises the involvement of the principal. Article 5, para. 5 OECD Model further excludes from the Agency PE definition the agent whose activities are limited to those mentioned in Art. 5, para. 4 OECD Model. Paragraph 4 excludes from the general PE and Agency PE definition, activities of a preparatory or auxiliary character. A marketing agent for example engages in activities of a preparatory or auxiliary nature. Para. 28 of the OECD commentary on para. 4 states:

"The fixed places of business mentioned in paragraph 4 (also applicable to the Agency $\mathrm{PE}, A P l$ ) cannot be deemed to constitute permanent establishments so long as their activities are restricted to the functions which are the prerequisite for assuming that the fixed place of business is not a permanent establishment. This will be the case even if

39 J.F.Avery Jones \& David. A. Ward, 'Agents as Permanent Establishments under the OECD Model Tax Convention', European Taxation, May 1993, p. 162; K. Vogel, op cit, n. 1, p 332 , expresses the same view.

40 A.A. Skar, op cit, n. 15, p. 494. 
the contracts necessary for establishing and carrying on the business are concluded by those in charge of the places of business themselves."

\subsubsection{Marketing Agent}

The term "marketing agent" has a very broad meaning. A marketing agent for example investigates what can be done to improve marketing performance, effectiveness and efficiency. He analyses market factors (market share, competition, etc.), buyer factors (consumer habits, buyer loyalty, etc.) and company factors (profits vs, volume, skimming vs. penetration, etc.) ${ }^{41}$

If a marketing agent concludes contracts necessary for his marketing activities, this concluding of contracts would not implicate that the marketing agent would fall within the definition of Art. 5, para. 5 OECD Model, provided that the concluding of contracts could be labelled as a part of the preparatory or auxiliary activities.

A 1983 Italian ruling ${ }^{42}$ showed a strict application of the Art. 5, para. 4 OECD Model exception-rule. A Swiss company (S) had an Italian purchasing agency, which exclusively bought goods for S. Ninety percent of the goods were despatched unaltered to $\mathrm{S}$ in Switzerland, while $10 \%$ of the goods were processed, transformed and repackaged by the Italian purchasing agency before being dispatched to $\mathrm{S}$.

Art. 5, para. 3(d) of the 1976 Italian-Swiss tax treaty states that the term "permanent establishment" does not include the maintenance of a fixed place of business solely for the purpose of purchasing goods, merchandise or for collecting information. Art. 7 , para. 5 of the same treaty further states that no profits shall be attributed to a $\mathrm{PE}$ by reason of the mere purchase by that $\mathrm{PE}$ of goods or merchandise for the enterprise. The Italian ruling holds that as soon as the activities of an establishment cease to be solely concerned with the purchase of goods, it ceases to have a preparatory or auxiliary character and becomes a PE. Because Article 7, para. 5 provides that no profits are deemed to arise out of the mere purchase of goods, the ruling holds that in this case only profits that may be taxed in Italy are those from the activities involving $10 \%$ of the goods.

The OECD Commentary contains two statements on this issue. When discussing a mix of several Art. 5, para. 4 OECD Model activities, paragraph 21 states that combinations of activities mentioned in Art. 5, para. $4(\mathrm{a}-\mathrm{e})$ shall be deemed not

41. W. Beacham, R.T. Hise \& H.N. Tongren, Beacham's Markering Reference, (vol. 1), (Research Publishing, Washington D.C., 1986), p. 410.

42 Italy/Swizerland, July 21,1983 note (no. 12/533), Edwardes-Ker, p. 53. 
to constitute a PE, provided that the overall activity of the fixed place of business resulting from this combination is of a preparatory or auxiliary character. An overall assessment could also very well be applied if a combination of activities containing both Art. 5, para. 4 activities and Art. 5, para. 5 activities are conducted by the (marketing) agent. The overall outcome could be that the fixed place of business as a whole has a preparatory or auxiliary function. The concluding of contracts [which could qualify as Art. 5, para. 5 activities] could be a small part of the overall business conducted by the marketing agent. The outcome could, obviously, also lead to a reverse outcome, meaning that the Art. 5, para. 5 activities could exceed the Art. 5, para. 4 activities and therefore lead to an Agency PE.

The line which has to be drawn between activities which have a preparatory or auxiliary character and those which don't, needs to be determined in each individual case. Paragraph 24 of the OECD Commentary on Art. 5, para. 4 states that the decisive criterion is whether or not the activity of the fixed place of business in itself forms an essential and significant part of the activity of the enterprise as a whole. This statement is in line with paragraph 33 of the OECD Commentary on Art. 5, para. 5 which states that the authority to conclude contracts must cover contracts relating to operations which constitute the business proper of the enterprise.

The (marketing) agent whose prime activities fall under the Art. 5, para. 4 list of activities, being of a preparatory or auxiliary character, but also concludes contracts in the name and on behalf of his principal can, in my view, only be deemed to constitute an Agency PE on behalf of his principal if two extra conditions are met, namely:

1. if the concluding of contracts constitutes the biggest part of his overall activities, and

2. the authority to conclude contracts covers contracts relating to operations which constitute the business proper of the principal.

\subsubsection{In the Name of}

Paragraph 31 of the Commentary on Art. 5, para. 5, 1977 Model, was renumbered and amended on 31 March 1994, and para. 31 became para. 32. At the end of this paragraph one sentence was added to the Commentary. The last sentence of paragraph 32 of the 1997 Model reads: 
"Also, the phrase "authority to conclude contracts in the name of the enterprise' does not confine the application of the paragraph to an agent who enters into contracts literally in the name of the enterprise; the paragraph applies equally to an agent who concludes contracts which are binding on the enterprise even if those contracts are not actually in the name of the enterprise."

The text of Article 5, para. 5, 1997 Model, states that a person who is acting on behalf of an enterprise, and habitually exercises an authority to conclude contracts in the name of that enterprise shall be treated as an Agency PE of that enterprise. As Skaar pointed out, the commentaries state that it is sufficient for the establishment of an Agency PE that the agent "has sufficient authority to bind the enterprise's participation in the business activity", and that the agent's "activity involve(s) the enterprise to a particular extent in business activities". Skaar concludes from this, that this statement, contrary to the text of the OECD Model, seems to emphasise the material relationship between the agent and the principal, and not the parties in the formal conclusion of the contract. ${ }^{44}$ This last conclusion by Skaar is obviously shared by the OECD; the agent does not necessarily have to enter into contracts literally in the name of the enterprise.

Skaar wrote this on the basis of the 1977 Model. The 1997 Model, however, seems to point in a different direction. The 1997 Commentary states that the agent who does not act in the name of the principal, but concludes contracts binding the enterprise can also establish an Agency PE. This last element points to a legal emphasis, namely contracts which are legally binding the principal, thus creating liability by contract for the principal. The reasons for this conclusion are obvious; if an agent concludes a contract which is binding on the enterprise (de facto the principal) it can only mean that the principal can sue based on the contract and be sued as well. ${ }^{45}$

In my view, the new commentary renounces the exclusive civil law element in the Agency PE provision, namely agents acting "in the name of" the principal. When a civil law agent acts in the name of his principal, he legally binds the principal, and can establish an Agency PE according to Art. 5, para. 5, OECD Model. The common law agency concept differs substantially from the civil law concept. For

43 Model Tax Convention on Income and on Capital, OECD Committee on fiscall Affairs, Updated as of 1st September 1995, loose-leaf edition, Paris.

44 A.A. Skatar, op cit., n. 15, p. 487.

45 P.S. Atiyah, An iwroduction to the Law of Contract, 4 th ed. (Clarendon Press, Oxford, 1989), p. 380 . 
extensive coverage of this particular legal problem, I would like to refer to Chapter II of this study. By stating that an agent who concludes a contract not actually in the name of the principal but still legally binds the principal can also be classified under the Agency PE provision, the OECD actually recognises the legal dimension and importance of this provision. Concluding contracts binding the principal is a very important, or perhaps, the most important element of the Agency PE provision. This conclusion refers to the view which the League of Nations Fiscal Committee proclaimed in their 1929 report. The agent's authority is, according to the Fiscal Committee: "A criterion of a legal nature, it being considered that the only agents dependent on an enterprise are those having sufficient powers to conclude contracts binding upon that enterprise." 46

The altered Commentary of the 1997 Model clearly tried to overcome interpretation problems on the acting "in the name of" element of Article 5, para. 5, OECD Model by emphasising the importance of concluding contracts binding the principal. This commentary means a fundamental change in Agency PE taxation, namely the abandonment of the exclusive "concluding contracts in the name of the principal" condition of the basic Agency PE definition. Because the OECD draughtsmen did not alter the literal treaty text, but only the Commentary, problems could arise, because according to the Commentary, an agent who concludes binding contracts, but does not conclude contracts "in the name of" the principal, could be deemed to constitute an Agency PE. This is an obvious inconsistency. In my view, it's important that this inconsistency be removed, simply by altering the treaty text of Art. 5 , para. 5 according to the OECD Commentary. The first sentence of Art. 5 , para. 5 should be formulated as follows:

"Notwithstanding the provisions of paragraphs $1-3^{47}$, where a person -other than an agent of an independent status to whom paragraph 6 applies- is acting on behalf of an enterprise, and has, and habitually exercises, in a Contracting State an authority to conclude contracts binding the enterprise, that enterprise shall be deemed to have a permanent establishment in that State..."

\subsubsection{Habitually Exercising the Authority}

The agent's authority to conclude contracts must be exercised habitually, according to paragraph 5. According to the OECD Commentary the use of the

46 LON, Doc. C.516.M.176.1929.11, Geneva, October 1926, 1929, p.3

47 See paragraph 8.2.2. of this study. 
term "permanent establishment" in this context presupposes that the agent makes use of his authority repeatedly and not merely in isolated cases. ${ }^{48}$

The reason for this condition is the resemblance with the regular permanent establishment of Art. 5, para. 1-3, OECD Model. In a 1934 German court case, the RFH pointed to the general PE connection, an Agency PE can only be present if it resembles the general $\mathrm{PE}$. The resemblance is present, according to the RFH, if the foreign company has a permanent establishment through which the agency is run. ${ }^{49}$ The Agency PE later on developed into a individual independent concept. ${ }^{50}$

In the 1929 Report of the Fiscal Committee of the LON, the current "habitually exercising the authority" condition was described as follows: "When a foreign enterprise regularly has business relations in another country through an agent established there, who is authorised to act on its behalf, it shall be deemed to have a permanent establishment." In this statement the term "regularly" is not specifically linked to the exercising of the authority by the agent, but more to the overall activities (business relations) of the foreign enterprise by means of its agent.

The ICC, at their 1931 conference, listed three conditions of an Agency PE:

(1) An authority to conclude contracts

(2) The habitually performing of such acts of trade

(3) A fixed place of business

This is the start of the current Agency PE condition that the agent must habitually exercise the authority to conclude contracts. If a foreign enterprise conducts a single transaction through an agent, even if the agent concluded the single contract "in the name of' the foreign enterprise, the foreign enterprise does not have an Agency PE because his activities in the agent's state are too brief to justify domestic taxation. The parallel with the construction PE of Art. 5, para. 3, seems evident: "A building site or construction or installation project constitutes a PE only if it lasts more than twelve months." An activity which lasts less than twelve months, is considered to be a preparatory activity. ${ }^{52}$ Although a building site is

48 Paragraph 32 of the OECD Commentary on Article 5.

49 RFH 29 Juni 1934, I A 56/33, Reichsstenerblatt 1934, Nr. 1008, paragraph 3.4.2. of this study.

50 Independent from the regular PE concept, meaning that an Agency PE does not require a permanent establishment through which the agent conduct his business on behalf on the principal.

51 LON, Document C 516.M.176.1929.11, Geneva, October 1929, p. 4.

52 According to the 1996 US Model Technical Explanation. 
obviously different than an agency, I think that the idea behind the time limit set in Art. 5, para. 3, also applies to the agency issue. The penetration of a foreign enterprise into to the domestic market must have some permanence, in order to justify domestic taxation. Only if a foreign enterprise engages an agent who conducts business transactions regularly, the foreign entrepreneur can be considered to be present in a state, by means of his representative (i.e. the agent), and this lasting presence can justify taxation by the agent's state.

\subsection{ARTICLE 5, PARAGRAPH 6, OECD MODEL}

\subsubsection{Treaty Text}

"An enterprise shall not be deemed to have a permanent establishment in a Contracting State merely because it carries on business in that State through a broker, general commission agent or any other agent of an independent status, provided that such persons are acting in the ordinary course of their business."

\subsubsection{Introduction to Paragraph 6}

Paragraph 36 of the OECD Commentary states that paragraph 6 has been inserted in Article 5 for the sake of clarity and emphasis. Emphasis, I gather, of the statement made in paragraph 32 of the Commentary, which reads: "It would not have been in the interest of international economic relations to provide that the maintenance of any dependent person would lead to a permanent establishment for the enterprise." The 1977 OECD Commentary even mentioned that a special paragraph on the PE-status of independent agents is unnecessary, because the independent agent represents a separate enterprise. ${ }^{53}$ Independent agents conduct business activities for foreign entrepreneurs as their own business, whereas dependent agents operate as integral parts of the principal's organisation. ${ }^{54}$

The U.K. introduced a paragraph 6-like exemption provision in 1915, primarily to protect its own economy. ${ }^{55}$ International economic relations would certainly be endangered if a double taxation convention would not have an exemption provision concerning independent agents. It would have serious economic consequences if trade through independent agents would be taxed. Foreign

53 Paragraph 35 of the 1977 OECD Commentary on Article 5 .

54 A.A. Skaar, op cit, n. 15, p. 474.

55 See paragraph 4.3.6.1. 
investors would certainly move their business to a State where these transactions would be exempted from Agency PE taxation.

Laleman states that, although Art. 5, para. 6 OECD Model refers to independent agents, the application of Art. 5, para. 5 of the OECD Model is, according to the treaty text, not exclusively restricted to dependent agents. An independent agent who binds his principal out of the ordinary course of his business, can also fall with the terms of Art. 5, para. 5 of the OECD Model. ${ }^{56}$ An independent agent who concludes binding contracts but meets the conditions of Article 5, para. 6, does not constitute an Agency PE. This leads to the conclusion that the condition of Article 5 , para. 5, namely the concluding of contracts in the name of the foreign enterprise cannot serve solely as the main condition which seperates the dependent and independent agents, because an independent agent could also conclude contract in the name of the foreign enterprise and still not constitute an Agency PE.

A broker should not be included in the category of independent agents of Art. 5, para. 6 OECD Model, because he merely brings parties together. ${ }^{57} \mathrm{~A}$ broker does not conclude contracts in the name of his principal, and could therefore never constitute an Agency PE because of the lack of required authority.

Two groups of independent agents are explicitly named, namely the broker and general commission agent. These two categories of agents were considered likely to be independent under domestic laws of all countries, and such agents were therefore not held to be an integral part of the business of the principal. ${ }^{58}$ The third and final group of independent agents is referred to as "any other agent of an independent status".

\subsubsection{Broker}

The broker is, generally, a person who merely brings parties together. He is not a party to the contract. A broker is, according to civil law and common law, not regarded as being an agent. Because of this reason, and the fact that the broker does not conclude contracts, the broker would not qualify as an Agency PE on the basis of Article 5, para. 5. Article V, para. 6, of the 1943 Mexico Model Protocol, therefore states:

56 P. Laleman, De agentuur vanuit fiscale hoek bekeken, A.F.T. I. January 1997, p. 24.

57 S.I. Roberts, "The Agency Element of Permanent Establishment: The OECD Commentaries from the Civil Law view (Part One), Infertar 1993/9, p. 413 .

58 A.A. Skaar, op cit., n. 15, p. 505 . 
"The fact that a broker places his services at the disposal of an enterprise in order to bring it into touch with customers does not in itself imply the existence of a permanent establishment for the enterprise, even if his work for the enterprise is, to a certain extent, continuous or is carried at regular periods..."

If a broker, however, performs services which exceed the regular broker activities, the broker could be regarded as acting outside the ordinary course of his business, and thus could find himself constituting an Agency PE on behalf of his principal if he meets the conditions of Art. 5, para. 5 OECD Model. In paragraph 8.3.8. the "ordinary course of business" test will be discussed.

\subsubsection{General Commission Agent}

The term general commission agent is a very broad term, covering several types of agents. In Chapter 2, I concluded that a general commission agent is usually translated as a "commissionaire", a typical civil law concept with its own typical civil law meaning and application. There are, nevertheless, several kinds of commissionaires, namely a purchasing and/or selling commissionaire, those who act at public auctions and who work at the stock exchange- in the US this type of intermediary would be called a stockbroker-and lastly, a commissionaire forwarding agent. 59 The word "general" is meaningful. The UK 1915 Finance Act and appropriate case law proved that the term "general" means that the commission agent worked for clients in a manner common to brokers, meaning he worked for any number of clients. According to the UK ruling concerning Fleming versus London Produce itd:

"... a commission agent ...holds himself out to work for clients generally, and who does not in substance confine his activities to one principal, or even an insignificant number of principals.

For example, the 1996 double taxation treaty between the Netherlands and Argentina contains an Agency PE exemption provision which in my view refers to the above-mentioned meaning of the word "general". Art. 5, para. 6 of the treaty

59 R. van Peteghem \& K. Beeckmans, De commisionairstructum in Belgie (The Belgium Commissionaire-structure), A.F.T. 11, Novernber 1996, p. 380.

60 Fleming vs. London Produce ltd. (1968) 44 TC 582. 
contains a provision identical to its OECD Model counterpart. The NetherlandsArgentina ${ }^{61}$ treaty provision, however, adds the following line to para. 6 :

"However, when activities of such an agent are devoted wholly or almost wholly on behalf of that enterprise and in his commercial or financial relations with the enterprise conditions are made or imposed that differ from those generally agreed to by independent agents, he will not be considered an agent of an independent status within the meaning of this paragraph."

This is a provision in my view is fully in line with the original exemption provision from the 1915 UK Finance Act- a meaning and interpretation which should be generally accepted. The exclusion of the commission agent referred to the general commission agent, the commission agent who worked for numerous clients. Because the term general commission agent is mentioned in Art. 5, para. 6 OECD Model, it should be noted that this group does not include the "exclusive commission agent" and/or the exclusive commissionaire. A different situation could arise if the commissionaire is not an actual person but a legal corporate body, like for example, a limited company. This issue will be addressed in paragraph 9.4.5.

\subsubsection{The Independent Agent}

The OECD Commentary contains three basic conditions which all independent agents must meet in order to be considered within the scope of paragraph 6 . The text of paragraph 37 of the OECD Commentary leaves no other conclusion:

"A person will come within the scope of paragraph 6-i.e. He will not constitute a permanent establishment of the enterprise on whose behalf he acts only if

a) he is independent of the enterprise both legally and economically, and

b) he acts in the ordinary course of his business when acting on behalf of the enterprise."

"Only if" these requirements are met, a person could be an independent agent in light of paragraph 6.

61 Convention between the Kingdom of the Netherlands and the Argentine Republic for the avoidance of double taxation and the prevention of fiscal evasion with respect to taxes on income and on capital, December 27, 1996, 98 TNI 19-1, Doc. 98-4044. 


\subsubsection{Legally Independent}

"Where a person's commercial activities for the enterprise are subjected to detailed instructions or to comprehensive control by it, such person cannot be regarded as independent of the enterprise," according to para. 38 of the OECD Commentary. In the Taisei case $^{62}$ the US tax court concluded that the US agent (a US company) was legally independent because the principal ${ }^{63}$ had no shareholder interest in the US company and no representative of any of the insurance companies was a director, officer or employee of the US company. The management agreement, concluded between the Japanese insurance companies and their US agent, granted complete discretion to the agent to contract the reinsurance contract on behalf of the insurers. They could issue any number of reinsurance contracts as they (the US agent) saw fit, as long as the net acceptance limit was not exceeded in each contract. The court stated that "even an independent agent only has authority to perform specific duties for the principal. It is freedom in the manner by which the agent performs such duties that distinguishes him as independent."

In the Dutch shipbrokers case (Cargadoorsarrest) ${ }^{64}$ the Dutch Supreme Court concluded that the principal's instructions were not so detailed and comprehensive that the Dutch shipbroker had no freedom in performing his duties. The Supreme Court agreed with the court of appeal that, taking into consideration the economically independent position of the shipbroker, the content of the management agreement (the agreement was a standard management agreement), the shipbroker had enough freedom to determine the quantity of commercial activities it would undertake on behalf of its principal.

In the Domroy case $e^{65}$ the independent agent is compared to an employee:

"An independent agent generally means one who, exercising an independent employment, contracts to do a piece of work according to his own methods and without being subject to control of his employer except as to the result of the work."

In conclusion, an independent agent is legally independent if he can conduct the business of the principal according to his own view, expertise and methods. The principal can certainly give instructions, but only regarding to the final business result. If the principal frequently intervenes when the agent is conducting his

62 Taise Fire and Marine Insurance Co. Ltd, 104 TC No.27 (May 2, 1992). See par. 5.10.1.

63 In this case four Japanese insurance companies.

64 Hoge Raad, 15 June 1988, Rolno. 24881 , BNB 1988/258.

65 Domoy Ltd., versus United Stcries, 301. F. 2d 200, 206 (9th Cir. 1982). 
business and the agent must comply, the agent would not meet the legally independency test.

An independent agent performs, so to speak, cettain services. If an enterprise engages such an agent, they engage him because he performs services required by the enterprise- for example, in the case of a ship broker, being an agent who takes care of custom services, payment of port charges, etc. The ship broker has the tequired expertise to perform those very duties. Because of this expertise, a ship owner would contract a ship broker. The ship owner would normally not intervene in the way the shipbroker performs his duties.

\subsubsection{Economically Independent}

If an agent is economically independent from his principal this would mean that if the principal would no longer require the services of the agent, the agent could still be in business. If the agent is economically independent from its principal, then the agent's business must be able to stand on its own and not look to the principal for its very economic viability. ${ }^{66}$

Meanwhile, if a principal pays the agent an arm's length commission, the agent, at least in that respect, has an economic independent position, whereas the agent who receives a remuneration only sufficient to cover expenses, could not be considered to be independent. This view is expressed by the U.S. tax court in the Taise Case $^{67}$ : "Finally, we think that the amount of Fortress' (i.e. the agent) profits is significant. For the three years in issue, Fortress was paid over 27 million dollars. This is not the kind of sum paid to a subservient company."

Two independent companies use arm's length prices (Art. 9 OECD Model) if they have business dealings with each other. If an enterprise engages a true independent dealer, the fee can only be an arm's length fee. A lower fee could only be paid if the dealer is in fact, to some extent, dependent upon its principal. According to the Technical Explanation of the 1996 U.S. Model treaty, a relevant factor in determining whether the agent is economically independent, is the extent to which

66 E. Madole, "Agents as Permanent Establishments under U.S. Income Tax Treaties', Tax Managenent International Joumal, June 10,1994.

67 Taisei Fine and Marine Insurance Co., Ldd., 104 TC No.27 (May 2, 1992). See para. 5.10.1. 
the agent bears business risk. ${ }^{68}$ The Technical Explanation highlights two important issues concerning the economic independence of the agent:

1) the agent must bear risks of loss from its own activities;

2) an exclusive or almost exclusive relationship with the principal may indicate that the principal has economic control over an agent.

These two issues capture, together with the arm's length commission, in my view, the main elements of a true economic independent agent. If an agent shares business risk with the principal or has its own business risk, the agent is economically independent because its business activities are not integrated with those of the principal. ${ }^{69}$ If an agent works exclusively for one (or few) enterprise he would likely be economically dependent. The more enterprises he represents, the more economically independent he will be. If one of the enterprises terminates the agency contract, the agent will still be in business because he is economically independent from one particular enterprise. The arm's length commission the agent receives, strongly points to an independent business partner because this fair market value commission is charged to any enterprise who wishes to engage the independent agent.

\subsubsection{Ordinary Course of his Business}

This test applies to the broker, general commission agent and any other agent of an independent status, and it was introduced in the OEEC 1958 report. The reason for this test is argued in the commentary:

"Where, for example, a commission agent not only sells the goods of the enterprise in his own name, but also habitually acts, in relation to that enterprise, as a permanent agent having an authority to conclude contracts, he would be deemed in respect of that particular activity to be a PE since he is thus acting outside the ordinary course of his own trade or business (namely that of a commission agent). ${ }^{, 70}$

68 Technical Explanation U.S. Model Income Tax Convention of September 20, 1996, Article 5, paragraph 6. This commentary on this particular point is more clear than the OECD Commentary. The economic dependency test is explained in more detail than the OECD Commentary counterpart.

69 Because according to para. 36 of the OECD Commentary, an independent agent represents a separate enterprise. Each enterprise, that of the principal and that of the agent, has their own specific business dealings.

70 OEEC Report, Paris 1958, p.52. See paragraph 7.6 of this study. 
It seems important to point to the 1943 Mexico Model where the draughtsmen used the phrase: "agents of genuinely independent status". "In my view, this test wants to prevent misuse of brokers or general commission agents. If an agent claims to be a general commission agent, he must act accordingly. If he, in fact, acts within the scope of Art. 5, para. 5 OECD Model, his status should not prevent him from the Agency PE status.

The OECD Commentary states that: "Persons cannot be said to act in the ordinary course of their own business if, in place of the enterprise, such persons perform activities which, economically, belong to the sphere of the enterprise rather than to their own business operations." 72 This statement points to a condition which focuses on the agent's $o w n$ business ${ }^{73}$ instead of the business of the group to which the agent belongs (for example, general commission agents, ship brokers or stock brokers). Later on, the Commentary, points to a comparison of a group of agents. This very issue is the most important element to the "ordinary course of business" test. The Commentary contains an example of an agent not acting in the ordinary course of his business:

"Where, for example, a commission agent not only sells the goods or merchandise of the enterprise in his own name but also habitually acts, in relation to that enterprise, as a permanent agent having an authority to conclude contracts, he would be deemed in respect of this particular activity to be a permanent establishment, since he is thus acting outside the normal course of his own trade or business (namely that of a commission agent).".74

This is an example, obviously, copied from the 1958 OEEC report. This example, in my view, shows that a comparison should be made to what an agent in his trade usually does. A commission agent concludes contracts in his own name, so if a commission agent concludes contracts in the name of a principal, he is acting outside the normal business of a regular commission agent. This view is expressed in multiple court decisions. For example, in a Bundesfinanzhof ruling of September $14,1994^{75}$, the German tax court ruled:

71 See fin. 392.

72 Paragraph 38 OECD Commentary on Article 5, paragraph 6.

73 The Commentary states that "persons cannot be said to act in the ordinary course of their own business..."

74 Para. 38 OECD Commentary on Article 5, paragraph 6.

75 Bundesfimanzhof 14 September 1994, I R 116/93, Bundessteuerblatt 1995, Teil II, nr. 6. 
"The conviction of the court is that the OECD Model Treaty wants to make the existence of an Agency PE depend upon an objective, abstract, comparison standard. This can only apply to the ordinary business activities of the professional groups named in Article 5 para 6 OECD Model Treaty." [See Appendix, Quote 23 for original in German.]

The BFH view was that the OECD Model implied that an objective, abstract comparison should be applied. This can only mean a comparison to the explicitly named groups of agents [according to Art. 5, para. 6 OECD Model). The example of the commission agent in para. 38 of the OECD Commentary also points to that directions, according to the $\mathrm{BFH}$.

In BNB 1971/43, the Dutch Hoge Raad ruled that the Dutch insurance broker of a US insurance company performed duties which a regular Dutch insurance broker did not perform. ${ }^{76}$ The insurance broker sold insurance policies at Schiphol Amsterdam Airport.

He concluded insurance contracts in the name of the US company. They sold the policies fully in accordance with the franchise manual, issued by the US company. In great detail, this manual regulates the explicit way in which the broker should sell the policies. This varied from the required tone of voice, choice of words to even the representative's facial expression. The Supreme Court ruled that this way of selling insurance policies is not in

accordance with the regular way in which a Dutch insurance broker operates. In conclusion, the "ordinary course of business" test, means that the activities of an independent agent must be compared to activities regularly performed by fellow agents active in the same type of business. For example, ship brokers must be compared to ship brokers and insurance agents to insurance agents.

\subsubsection{Interpretation of the Agency PE}

\subsubsection{Introduction}

Several distinguished authors published their interpretation on the Agency PE provision under the OECD Model and the independent agency exemption rule under Article 5, para. 6.

J. Avery Jones and D. Ward ${ }^{77}$ and S. Roberts ${ }^{78}$ published important articles in 1993, and recently G. Persico ${ }^{79}$ introduced a good analysis of the Agency PE

76 Hoge Raad, 13 january 1971, Rolno. 16.445, BNB 1971/43.

77 J.F. Avery Jones \& David A. Ward, European Taxation, May 1993.

78 S. Roberts, Intertax, $1993 / 9$. 
provision. In the next paragraphs I will summarise their conclusions and conclude with my own analysis.

\subsubsection{Avery Jones and Ward on the Agency PE}

Avery Jones and Ward analyse the Agency PE provision from a civil law as well as from a common law standpoint.

From a civil law standpoint Article 5, para. 6, is redundant, because civil law independent agents usually do not bind their principals. It could only apply to independent agents who act in the ordinary course of their business, although they conclude binding contracts.

Scheme: Avery Jones and Ward civil law interpretation

\begin{tabular}{|l|}
\hline Para. 5 \\
Dependent agents who \\
conclude contracts in \\
the name of principal
\end{tabular}

\section{Para. 6 \\ Independent agents \\ who conclude contracts \\ in the name of principal}

Cases where the principal is not bound by the agent's contracts, like e.g. in the case of the civil law commissionaire, fall outside both Article 5, para. 5 and para. 6, and no not in any circumstances create an Agency PE, whether or not the agents are acting in the ordinary course of their business. ${ }^{80}$

From a common law standpoint, Avery Jones and Ward conclude that para. 6 has a significant function because according to common law independent agents usually bind their principal if they act on their behalf. In other words, all common law agency contracts have the same effect as the civil law concept of direct representation.

Scheme: Avery Jones and Ward common law interpretation

\section{Para. 5}

Dependent agents who conclude binding contracts

\section{Para. 6}

Brokers, general commission agents and other independent agents

79 G. Persico, Intertax, $2000 / 2$.

80 J.F. Avery Jones \& David A. Wand, p. 156. 


\subsubsection{Roberts on the Agency $P E$}

From the text of Article 5, para. 5, Roberts concludes that the OECD provision is based on civil law concept. The phrase "conclude contracts in the name of the enterprise" indeed refers to the civil law agency concept of direct representation. Therefore, Roberts concludes, in Article 5, para. 6, the concept of indirect representation is the leading principle. He based this last conclusion primarily on paragraph 38 of the OECD Commentary where an example is given of a commission agent who does not act in the ordinary course of his business, namely if the commission agent concludes contracts in the name of the foreign enterprise.

Another important point that Roberts raises is, that if an agent concludes contracts in the name of the principal he is in fact conducting the business of the principal, whereas an agent who concludes contracts in his own name, he acts in the sphere of his own business.

Scheme: Roberts interpretation

\section{Para. 5}

Direct representation

Conducting the

business of the

principal

\subsubsection{Other views}

Another view on Article 5, paragraphs 5 and 6, as Persico clearly explains in his Intertax article, was put forward by two German authors Kroppen and Huffmeier. ${ }^{81}$

An important new argument that both authors put forward is that an independent agent is independent according to para. 6 as long as he acts in the ordinary course of his business. In this analyses it is of no importance whether or not the independent concludes binding contracts. They based this conclusion on the fact that para. 6 does not mention the authority to conclude binding contracts.

$81 \mathrm{H} . \mathrm{K} . \mathrm{Kroppen} / \mathrm{S}$. Hüffmeier, "The German Commissionaire as a Permanent Establishment under the OECD Model Treaty", Intertax, 1996/4. 
They also stipulate that if an independent agent does not meet the conditions of para. 6, he can only constitute an Agency PE if he meets the conditions laid down in para. 5.

\subsection{CONCLUSIONS}

The fact that Article 5, para. 5, contains the legal concept of the authority to conclude contracts in the name of the enterprise, is a significant factor in analysing the content and range of this article. The altered OECD Commentary of March 1994 contributed a important clarification of this key element of para. 5. The fact that if an agent does not conclude contracts literally in the name of a principal, does not mean that he does not qualify under para. 5 as long he concludes contracts which are binding the principal.

This new element, the concluding of binding of contracts, is not only important for common law jurisdictions but should, in my view, also play a role in civil law jurisdictions. Under civil law, an agent who does not conclude contracts in the name of the principal could still, under certain circumstances, be considered to conclude contracts binding the principal. If a civil law agent does not conclude contracts in the name of the principal and also does not bind the principal, an Agency PE should be out of the question, because the legal agency concept leaves no other choice. Although this agent might be very active on behalf of his principal, an Agency PE status in this case would be contrary to the formulation of this provision.

A separate exenpition -provision, 'ilke 'the current para. ' 6 , is still needed. The broker should be omitted from this provision, because a true broker does not conclude contracts, he only brings parties together. An independent agent should be excluded from the Agency PE status although he could conclude binding contracts. An agent is an independent agent if he is both economically and legally independent and acts in the normal course of his business. The term general commission agent is, translated in civil law terms, a commissionaire. A civil law commissionaire does not conclude contracts in the name of the principal and would therefore, generally speaking, not have to be included in para. 6.

Common law general commission agents are a large group of different kinds of agents which, within the common law concept, conclude binding contracts. An exemption provision, like para. 6 , is needed for these independent agents.

De lege ferenda, Article 5, para. 5 could be simplified by stating that agents, not independent agents according to para. 6 , who have the authority to conclude 
binding contracts on behalf of the foreign enterprise, and habitually exercise the authority, constitute an Agency PE.

The exemption provision of para. 6 should stipulate that independent agents, who are both legally and economically independent, and act in the ordinary course of their business, do not constitute an Agency PE.

Scheme: Author's interpretation

\section{Para. 5}

Agents concluding binding contracts

\section{Para. 5}

Agents legally \& economically independent, acting in the ordinary course of their business 



\section{CHATH \\ Practical Applications}

\section{1}

INTRODUCTION

This chapter will analyse a major practical application of the Agency PE concept in modern trade business, the commissionaire structure. In practice this structure is commonly used when (often) US companies wish to establish a European distribution network. Its often the case, in this context, that a commissionaire only serves one principal (the US company), and this case will especially be the topic of discussion. (The questions concerning VAT consequences of the commissionaire structures are beyond the scope of this study.) The second part of this chapter will deal with the Agency PE and the possible implications in the case of Internet business transactions. This chapter will also deal with other practical current agency applications and perhaps complications when dealing with concepts like pooling arrangements and partnerships, and it will briefly focus on the insurance agent.

\section{2}

\section{THE COMMISSIONAIRE STRUCTURE IN GENERAL}

Multinational enterprises may distribute their products through a great diversity of methods, including the following:

- a distributor who acts in his own name and for his own account, a "buy-sell arrangement";

- a commission agent who acts in the name and for the account of the principal (i.e. direct representation or disclosed agent);

- a commissionaire who acts in his own name but for the account of the principal (i.e. an indirect representation or undisclosed agent).'

A distributor doesn't create tax liability for the company whose products are being distributed. The distributor is not considered to constitute an Agency PE of the foreign supplier because the distributor acts in his own name and for his own account. Because of this very reason, the distributor is not legally an agent

1 M.F. Swanick, M. Mudrick, \& E. Bouwman, 'Tax and Practical Issues in Commissionaire Structures', Tax Notes International, January 13, 1997, p. 137. 
and conducts his own business. Using a distributor could possibly lead to lesser profits, because the distributor might bear all the risks involved when selling the products to customers. This depends nevertheless on the agreement concluded between the manufacturer and distributor. Both parties can agree on a certain apportionment of the risks, which obviously has bearing on the actual cost price for the distributor. For example, the distributor could maintain a stock of goods subject to all sorts of financial risks. He would normally also fully bear the debtors risk and will obviously influence the prices the distributor has to pay when buying the products from the production company.

A commission agent is a straightforward agent fully complying with the basic concept of the Agency PE. The commission agent acts in the name of the principal and for the account of the principal. Using a commission agent will usually lead to tax liability for the foreign principal in the commission agent's state, unless the agent fully complies with the conditions of the independent agent, laid down in, for example, Art. 5, par.6, OECD Model. Finally, the commissionaire is -according to civil law jurisdlictions-a person who acts in his own name but for the account of any number of principals. Using the civil law commissionaire usually does not lead to tax liability in the commissionaire's state. All the profits arising from the business transactions concluded by the commissionaire are fully allocated to the principal's state. The commissionaire will be taxed on his commission in his own state.

In countries where the commissionaire has a safe place on the statute book, the commercial benefits of market presence generated by the commissionaire, the additional element of control available to the principal compared to the buy-sell structure, the increasing influence over both marketing and pricing by means of stipulated rights and, thus, over profit and loss management, and the protection against the assumption of permanent establishment taxation have created a ground swell in certain industries for both the sale of products and the provision of services to be rendered through the commissionaire. ${ }^{2}$ The principal is contractually bound to the commissionaire to deliver the goods sold to the customer and the commissionaire is contractually bound to the principal to remit the price received from the customer. ${ }^{3} \mathrm{~A}$ commissionaire, in the traditional sense, acts for any number of clients. It's however possible that a group company acts as a commissionaire and in fact acts for no other principal or principals than companies belonging to the same corporate group. Because

2 C. Brodersen \& $\mathrm{H}$. von Kolczynski, 'The Commissionaire: A Tax-Focused Evaluation from Germany", Mertax, Volume 25, lissue 5, p. 202.

3 J. Ghysbrecht, Saming fox when selling in Europe, European Counsel, October 1996, p. 29. 
there are in this case intercompany relations, according to Art. 9(b) OECD Model, the commercial and financial relations between the principal and the commissionaire subsidiary may not differ from those which would have been made between unrelated enterprises. In other words, the commissionaire must receive an arm's length remuneration. However, this conclusion leads to a highly attractive commissionaire structure if the arm's length remuneration of the commissionaire is small, and the profits of the principal can be kept in a low tax regime, by not having a permanent establishment/Agency PE in the sales jurisdiction. The arm's length remuneration for a commissionaire may be relatively small on account of the limited services it undertakes and the lack of risk it bears. ${ }^{4}$ If a US manufacturer considers using a European commissionaire for the distribution of products in Europe, significant US tax benefits could arise. The main tax advantage relates to the subpart $F$ legislation.

\subsection{SUBPART F ADVANTAGE}

U.S. domestic tax law (I.R.C.) contains four extensive anti-deferral regimes. If a US taxpayer conducts business abroad directly through a PE, the income which is earned by means of that PE is fully taxed in the US as foreign-source income. If, however, a US taxpayer uses a foreign subsidiary to conduct business abroad, there will normally be no US taxation unless the earnings are distributed to the US shareholders by means of a dividend distribution or by means of selling the stock in the foreign corporation. This system is called the deferral principle. It's an effective way to stall US taxation, and if the period of deferral is long enough, it has substantially the same effect as exempting foreign income from taxes, assuming there is in fact a low effective foreign tax rate.

The Internal Revenue Code contains several types of rules which prevent application of the deferral principle in a number of situations, one of these rules is generally referred to as part $\mathrm{F}$ legislation. ${ }^{6}$ To activate subpart $\mathrm{F}$ legislation, there must be a controlled foreign company $(\mathrm{CFC})$. A foreign corporation is a CFC if "United States shareholder(s)" own more than 50 percent of the total combined voting power of its stock or more than half of the stock's total value.

4 D. Morgan, "Selling out from the centre", Intemational Tax Review, 1997/?, p. 29.

5 R. Doenuberg, International taxarion, p. 171.

6 These four regimes apply to (1) the foreign personal holding company I.R.C Sections 551$558,(2)$ the controlled foreign corporation I.R.C. Sections $951-964,(3)$ the foreign investment company I.R.C. Sections $1246-1247$ and (4) the passive foreign investment company I.R.C. Sections $129 \Perp-1297$. 
According to I.R.C. $\$ 957$ (a) a US shareholder is defined as a US person owning at least 10 percent or more of the total combined voting power of the corporate stock. If a US company or group uses a CFC as a buy/sell distributor, the distributor's sales income will often constitute subpart F income, when the distributor is actually buying from a related party or selling to a related party, taxable to the US parent. This foreign base company sales income includes income generated by such trading activity whether the foreign corporation buys and resells the property or merely acts as a sales agent or representative in return for a sales commission. ${ }^{\text {? }}$

Subpart $\mathrm{F}$ income includes income from internal sales transactions. Sec. 954(d)(1) states:

"...the term 'foreign base company sales income' means income (...) derived in connection with the purchase of personal property from a related person and its sale to any person, the sale of personal property to any person on behalf of a related person, the purchase of personal property from any person and its sale to a related person..."

U.S. subpart $F$ legislation can be avoided insofar as it is based on internal sales transactions. A CFC may generate foreign base company sales income by buying or selling personal property on its own account or by acting as a commission agent. ${ }^{8}$

If the CFC, however, acts as a civil law commissionaire, it does not purchase the goods from its parent, the legal title of the goods is directly passed on from the principal to the third party, or in other words, by utilising a commissionaire arrangement, the sale would be deemed to be made directly by the principal to the local customer, and not to the related-party distributor, thereby avoiding subpart $F$ legislation. ${ }^{10}$

7 C.H. Gustafson, R.J. Peroni, \& R.C. Pugh, Taxation of Imiermational Transactions, (West Publ. Co., St. Paul, Minn., 1997), 6115.

8 M.I. Mclntyre, 'The International Income Tax Rules of the United States', p. 6-37a.

9 H. Pijl \& P. Willeme, 'Permanent Agent - With Particular Reference to Dutch Case Law', IBFD Bulletin, 1998/?, p. 12.

10 M.F. Swanick, M. Mudrick, \& E. Bouwman, op cit, n. 1, fn 420. 


\subsubsection{Introduction}

If a civil law commissonaire acts for any number of principals and therefore can be considered to be a genuine independent agent, no Agency PE status can be ascribed to the commissionaire. But if the commissionaire acts for only one client or principal, the previous conclusion could perhaps not be apply. The, what I would like to call, ${ }^{11}$ exclusive commissionaire will be analysed in the following paragraphs. These paragraphs deal with specially tailor-made commissionaires. If a company deals with a regular, already existing commissionaire no problems regarding the Agency PE status would occur. This could not be the case if a foreign company creates a commissionaire who works exclusively for that company. I will also discuss a subsidiary company who acts as a buy-sell subsidiary and is then restructured in order to act as a commissionaire.

\subsubsection{The Commissionaire according to the OECD and UN Modell}

Article 5(6) of the OECD Model stipulates that a foreign enterprise has no Agency PE if his business is carried on through a broker, general commission agent or any other independent agent, provided that they act in the ordinary course of their business. As I argued in Chapter IV of this study, the term "general commission agent" was derived from the UK Finance Act of 1915. UK legislators defined the term "general commission agent" as a commission agent who acts for a number of clients. ${ }^{12}$ The term "general" in fact refers to the agent who works for any number of clients, as was expressed in Fleming versus London Produce Co. Lid. (1968):

"...the word 'general" in the phrase general commission agent must have the same import;... that of a commission agent who holds himself out as being ready to work for clients generally, and who does

11 A. Pleijsier, "De vaste vertegenwoordiger in beweging en de commissiorair op de tocht!" ("The Agency PE concept is changing and the commissionaire is at risk'), Weekblad Fiscad' Recht, 1998/6274, p. 5-20; and a commentary entitled 'De commissionair met èen principaal loopt risico!' ('The exclusive commissionaire runs the risk'), Weekblad Fiscaal Recht $1998 / 6286$, pp. $500-503$.

12 See paragraph 4.4 of this study. 
not in substance confine his activities to one principal, or even an insignificant number of principals."

From this I conclude that the general commission agent of Art. 5 (6) OECD Model is a commission agent who works for a number of principals. The exclusive commission agent, working for only one principal, does therefore not qualify as a general commission agent. This same line of reasoning can be found in US tax law. Treasury Regulations $\$ 1.864-7$ (d)(3)(iii) stipulates that in the case of an exclusive agent:

"...the facts and circumstances of a particular case shall be taken. into account in determining whether the agent, while acting in that capacity, may be classified as an independent agent."

An agent can be regarded as an independent agent by law, the facts and circumstances can prove otherwise.

The UN Model treaty is very clear about the exclusive agent. In Art. 5(7) UN Model provision is laid down which is almost an exact copy of Art. 5(6) OECD Model, the provision which exempts the independent agent from the Agency PE status. Art. 5(7) UN Model, however, adds an extra sentence to the independent agent exemption rule:

"However, when the activities of such an agent" are devoted wholly or almost wholly on behalf of that enterprise, he will not be considered an agent of an independent status within the meaning of this paragraph."

A very clear statement; while U.S. tax law leaves room for the exclusive agent to prove his independent status, the UN Model rules out every such possibility: the exclusive agent is under no circumstances an agent of independent status.

The foreign principal who conducts his business through an exclusive civil law commissionaire would also not be exempt from Agency PE taxation on the basis of Art. 5(6) OECD Model. This does not necessarily mean that an Agency $\mathrm{PE}$ is deemed to be constituted if a double taxation convention has an OECD Model-like Agency PE provision. If an agent isn't considered to be an

13. I. Megarry in Fleming wersus London Produce Co. Ltd. (1968) 44 TC 582, 596.

14 Referting to the broker, the general commission agent or any other agent of an independent status. 
independent agent [according to Art. 5(6) OECD Model], the next obvious step in the analysis would be to analyse if the exclusive commissionaire meets the conditions of Art. 5(5) OECD Model, and thus is an Agency PE of his principal.

\subsubsection{The Altered OECD Commentary}

In March 1994 the OECD Commentary on Art. 5(6) was altered. Paragraph 32 of the Commentary stated:

"Also, the phrase 'authority to conclude contracts in the name of the enterprise' does not confine the application of the paragraph to an agent who enters into contracts literally in the name of the enterprise; the paragraph applies equally to an agent who concludes contracts which are binding on the enterprise even if those contracts are not actually in the name of the enterprise."

According to the Commentary the Agency PE concept applies to agents who conclude contracts binding the principal. So, if the exclusive commissionaire concludes binding contracts, the principal is deemed to have an Agency PE, unless the commissionaire meets the conditions of Article 5, para. 6, OECD Model, and therefore could be regarded as being an independent agent.

The term "binding" is usually interpreted as creating a legal obligation, either one's own or another person's. In this sense, a binding contract is a contract which is enforceable. ${ }^{15}$ If a commissionaire concludes a contract with a third party, and the third party can enforce the contract towards the principal, a binding contract exists. It does in my view not necessarily mean that this liability can only be derived from one particular field of law. In this light I would like to refer to the common law concept of the "undisclosed principal". If a person appears to be contracting only for himself, but in fact is acting for a principal, based upon rules of contract law, the agent is party to the contract. The third party clearly intended to deal with the agent alone. However, beginning some two hundred years ago, the courts came to hold that the principal could sue as a party to the contract and this has been the rule ever since, in order to protect the principal or the third party in certain circumstances from the harshness of the general principles of contract law. These rules are contained in the law of agencies, a particular field of common law. Both areas of the law, namely contract law and the law of agencies, are applicable to

15 According to Ballewtine "s Law Dictionary (Delmar Publ. Inc, Albany N. Y., 1994).

16 See para. 2.2.3. of Chapter II of this study. 
Liability issues regarding contracts concluded by and between principai, agent and third party.

If the agent acts on behalf of a principal whose existence he does not at the time disclose (the undisclosed principal), the other contracting party, when he discovers the true facts, is entitled to elect whether he will treat principal or agent as the party with whom he dealt. ${ }^{17}$ It is a basic principle of contract law that the identity of the parties is a term of the agreement. Thus it may be seen that the rule by which an undisclosed principal is made a party is quite inconsistent with the basic contract principle. In fact, the principal becomes a party to a contract made on his behalf by his agent only because of a concept particular to the law of agency which ignores the rules on contract. ${ }^{18}$ The liability of the "undisclosed" principal conflicts with contract law but nevertheless is established on the basis of the law of agency.

This liability aspect of the undisclosed principal clearly resembles regulations of the Dutch Civil Code concerning assignment (lastgeving).

\subsubsection{The Legal Aspects of the Dutch Commissionaire}

The commissionaire is an intermediary who acts for the account of his principal but concludes contracts in his own name. He is legally liable for two agreements:

1. the agreement he concluded in his own name with a third party (for example a sales contract);

2. the commission agreement concluded with the principal.

According to the Dutch Civil Code (Burgerlijk Wetboek) the commissionaire acts on the basis of assignment (lastgeving). According to Article 414 Dutch Civil Code, "assignment" is an agreement where one party obliges himself to undertake legal transactions for the account of the other party. Interesting is the fact that para. 2 of Article 414 stipulates that the agreement can provide that the commissionaire concludes contracts in his own name or in the name of the principal. In light of avoiding the Agency PE status, this a very important assessment.

17 Anson's Law of Contract, p. 560.

18 H.G. Reuschlein \& W.A. Gregory, The Law of Agency and Partmership, 2nd ed., 1990, p. 163. 
Article 421 Dutch Civil Code includes a provision which determines that if a commissionaire (as a lasthebber) doesn't fulfil his contractual obligations towards the third party, the third party can hold the principal liable to the contract even if the contract was concluded in the name of the commissionaire. This provision works in two cases, namely when the commissionaire does not fully fulfil the commitments dictated by the contract, or when the commissionaire goes bankrupt. ${ }^{19}$ This is the situation in which the principal incurs liability by virtue of a transaction conducted by the commissionaire in the commissionaire's name.

This legislation closely resembles the undisclosed principal liability rules, as discussed in Chapter II and the previous paragraph. My conclusion is that the commissionaire thus can be regarded as a person who concludes contracts which are binding the principal, or in other words create legal liability for the principal. Although this standpoint is certainly no commonis opinio among Dutch lawyers, ${ }^{20}$ there are civil lawyers who believe that a commissionaire can conclude binding contracts. For example, L.D. van Setten stated that if the legal relationship between the principal and the intermediary is governed by Art. $7: 414 / 424$ Dutch Civil Code (regulations on assignment, or lastgeving), the intermediary is authorised to bind the principal within the parameters set by the principal. Analogous to the American common law rule, one could determine that: "It may be said that the principal becomes a party to the contract by operation of law, without the will of the third party, and in some cases, without the will of the principal (Restatement $2 \mathrm{~d}$, Ag., para. 184, comment a)."21 In my view, it is a standpoint which in light of the Agency PE interpretation is a viable view, because in light of the altered OECD Commentary (see para. 9.4.3.), an agent who does not conclude contracts "in the name of" his principal can also establish an Agency PE if the contracts he concludes are binding the principal, unless he could be regarded as an independent agent, according to Article 5, para. 6, OECD Model.

19 W.C.L. wan der Grinten, Lastgewing, Monografieën Nieuw BW, B81, (Kluwer, Deventer, 1993), p. 53.

20 For example, see A. Grimme \& S. Y.T.H. Mejer, 'De commissionair is niet een vaste vertegenwoordiger!", Weekblad Fiscaal Recht 1998/6286; H. Pijl \& Peter Willeme, "Permanent Agent- With Particular Reference to Dutch Case Law", IBFD Bulletim, 1998/?

21 L.D. van Setten, De commissionair in effecten (the stockbraker), dissertation, (Kluwer, Deventer, 1998), pp. $283 \& 284$. 


\subsubsection{The Subsidiary Company as an Exclusive Commissionaire}

\subsubsection{Introduction}

My analysis of the exclusive commissionaire in the previous paragraphs is prompted from the assumption that the commissionaire is a person of flesh and blood. In practice, however, the fact often is that a subsidiary company acts as a commissionaire on behalf of the group company or its parent company. A company is, according to Art. 3 (1) (b) OECD Model, any body corporate or any entity that is treated as a body corporate for tax purposes. Because a subsidiary company is a legally independent entity, ${ }^{22}$ the question is whether a subsidiary company which acts as an exclusive commissionaire could still be regarded as an independlent company, and therefore avoid the possible tax implications which l've pointed out in previous paragraphs.

\subsubsection{Article 5, Paragraph 7, OECD Model}

A relevant provision in this respect is Article 5 (7) OECD Model, which reads:

"The fact that a company which is a resident of a Contracting State controls or is controlled by a company which is a resident of the other Contracting State, or which carries on business in that other State (whether through a permanent establishment or otherwise), shall not itself constitute either company a permanent establishment of the other."

The concept behind this paragraph is that a subsidiary company is, for tax purposes, regarded as a separate legal entity. Even the fact that the trade or business carried on by the subsidiary company is managed by the parent company does not constitute the subsidiary company a permanent establishment of the parent company, according to paragraph 40 of the OECD Commentary on Art. $5(7)$.

The legally independent status does not quallify the subsidiary company automatically as an independent agent according to Art. 5(7) OECD Model ${ }^{23}$ Paragraph $4 \|$ of the OECD Commentary on Art. 5 (7) states likewise:

22. Paragraph 40, OECD Commentary on Article 5 (7).

23 H.K. Kroppen \& S. Hüftmeier, 'Der Kommissionär als Betriebsstätte nach dem OECD Musterabkommen' (The commissionaire as a PE according to the OECD Model treaty'), Internationale Wrischafts-Briefe, no 21. November 8, 1995, p. 1000. 
"However, a subsidiary company will constitute a permanent establishment for its parent company under the same conditions stipulated in paragraph 5 as are valid for any other unrelated company, i.e. if it cannot be regarded as an independent agent in the meaning of paragraph 6 , and if it has and habitually exercises an authority to conclude contracts in the name of the parent company. And the effects would be the same as for any other unrelated company to which paragraph 5 applies."

\subsubsection{Analysis}

The OECD Commentary clearly states that the subsidiary company cannot hide behind its legal independent status. The subsidiary company which acts as an exclusive commissionaire can only be regarded as an independent agent if the conditions of Art. 5 (6) are met, namely if the subsidiary company is both legally and economically independent and acts in the ordinary course of their business.

In a 1963 Belgian Supreme Court ruling (the Dollfus-Mieg \& Co. case) . $^{24}$ the Belgian Supreme Court (Hof van Cassatie) found that the legal independent status of a subsidiary company overrules the permanent establishment concept. A French parent company sold its products on the Belgian market through its Belgian subsidiary company. This company was subject to comprehensive control by the French parent company, although it was financially and managerial independent. The subsidiary company received a $10 \%$ commission on the sales of the French products.

The Belgian Supreme Court ruled that the Belgian subsidiary company was a fully autonomous company and could therefore not be regarded as a Belgium $\mathrm{PE}$ of the French parent company. Van Peteghem and Beeckmans conclude that Art. 5(7) does not harm the application of Art. 5(5) OECD Model, meaning that a subsidiary could constitute an Agency PE on behalf of its parent company if it had the authority to conclude contracts in the name of the parent and habitually exercised that authority. ${ }^{25}$

The National Carbide case, ${ }^{26}$ a 1949 US court case, is also a relevant ruling. The taxpayer corporation was a wholly owned subsidiary company of a parent

24. Hof van Cassatie, 22 oktober 1963, La Revenue Fiscale. 1963,542.

25 R. van Peteghem \& K. Beeckmans, ibid, p. 397.

26 National Carbide Corp., 336 U.S. 442 (1949). 
company that used it for manufacturing and selling products. An agency contract was concluded between the parent and subsidiary company. The court ruled that a taxpayer could prove that a subsidiary company is a true agent of its principal by establishing that:

- The subsidiary concludes contracts on behalf and in the name of the parent (the principal);

- The parent is bound by the actions of the subsidiary;

- The subsidiary transmitted money it received to its principal;

- The receipt of income by the subsidiary was attributable to the services of the principal's employees and to assets belonging to the principal;

- The subsidiary's relationship with the principal was not dependent on the fact of the principal's ownership;

- The subsidiary's business purpose was carrying on the normal duties of an agent.

The Court went on to say that, although complete control did not in itself create agency status, the Court did not preclude the possibility of a subsidiary (or wholly owned corporation) as agent of its owner, because any third party can be an agent. ${ }^{27}$ The six considerations of the US Tax Court in the National Carbide case show that a subsidiary company will only be regarded as an agent if it acts as a regular agent (carrying on the normal duties of an agent) and having the required authorisation. If not, an agency will not be considered.

In the 1988 Bollinger case, ${ }^{28} \mathrm{Mr}$. Bollinger incorporated a company and transferred property to it to avoid the usury laws. The company assumed the mortgage. An agreement between Bollinger and the company stated that the latter was a pure nominee corporation and acted solely as an agent. In this case the court adhered to the principles set out in the National Carbide case.

Beginning this century, it was a communis opinio in US tax practice that corporations having a business purpose are separate taxable entities. When there is no agency contract, nor any indication of agency, the mere fact of the existence of a corporation with one or several shareholders, regardless of the corporation's business activities, does not make the corporation an agent of the shareholder. ${ }^{29}$

27 J. Nitikman, "The Meaning of "Permanent Establishment" in the 1981 U.S. Model Income Tax Treaty: Part 2', The Intentational Tax Jourmal, vol 15:3, 1989, p. 272.

28 Bollinger, 86-2 U.S.T.C. $19821\left(6^{\text {th }}\right.$ Cir.), aff d, 108 S. Ct. 1173, 99 L.Ed.2d. 357 (1988).

29 Moline Propertics, Inc, 319 U.S. 436 (1943). 


\subsubsection{Conclusion}

Considering case law and OECD Commentary, I think it's clear that the leading principle is that a subsidiary company is a legally independent entity. This principle is undisputed. It is also undisputed that a subsidiary company could constitute an Agency PE if it acts fully in accordance with the Art. 5(5) conditions. If a subsidiary company acts for the account of its parent company and concludes contracts in the name of (or binding) the parent company, it could constitute an Agency PE of the parent company, unless it is an independent agent according to Article 5, para. 6, OECD Model.

The National Carbide Case ${ }^{30}$ shows that there is no reason why a subsidiary company acting as an agent of its parent company, should be treated differently then a third party acting as an agent.

The subsidiary company which acts as an exclusive commissionaire on belalf of its parent company would normally conclude contracts in its own name, and therefore, in most jurisdictions, do not conclude binding contracts. This would obviously lead to the conclusion that this company does not constitute, according to Article 5, para. 5, OECD Model, an Agency PE of its parent company. But if, like in some jurisdictions could be the case, the subsidiary company concludes binding contracts, Agency PE status could still be avoided if the conditions of Article 5, para. 6, OECD Model, are met.

The subsidiary company should, however, be legally and economically independent and act in the normal course of its business, according to para. 37, OECD Commentary on Article 5, para. 6. If the subsidiary acts exclusively for one principal, e.g. its parent company, the subsidiary company is economically dependent of its single principal, the parent company. All of its profits are derived from the business transactions the subsidiary company performs on behalf of its parent. Agency PE status, in this case, is justified.

\subsubsection{The Transformation of a Buy-Sell Subsidiary into a Commissionaire}

When a buy-sell subsidiary company (from hereon "buy-sell sub") is transformed into a commissionaire, several important changes can be discerned. A buy-sell sub usually concludes contracts in its own name and for its own account, where a commissionaire also concludes contracts in his own name but for the account of a principal. The buy-sell sub buys products from its parent company or other group companies, and sells it to third parties on its own 
behalf. It assumes credit risks and risks of stock obsolescence. In conclusion, the buy-sell sub takes high risks and thus can generate high profits.

Another current appearance is the "stripped buy-sell subsidiary company". This company acis the same as a regular buy-sell sub, but certain functions and risks remain with the parent company. Because the stripped buy-sell sub assumes lower risks, the profits which can be allocated to this company are, compared to a regular buy-sell sub, lower. ${ }^{31}$

The transformation into a commissionaire implies that many of the risks ${ }^{32}$ that were previously borne by the buy-sell sub are now transferred to the parent company. The subsidiary company no longer earns profits on its sales, but instead should receive an arm's length commission. Because the transfer of risks, tax authorities could decide that this implies a transfer of goodwill from the buy-sell sub to its parent company. The goodwill which the buy-sell sub generated over the years is transferred to its parent company. The buy-sell sub used to sell products for its own account, but now works for the account of the parent company. The list of customers is, not literally however, transferred to the parent company, or in other words, will be used directly for the parent company. If the parent company does not pay for this transfer of the list of customers, the tax authorities claim, a distribution of dividends from the subsidiary company to its parent is assumed to have taken place.

The transfer of goodwill could then be treated as a distribution of dividends from the subsidiary company to its parent company. In Germany the tax authorities do recognise, in this case, a distribution of dividends if a third (independent) company that could be compared to the buy-sell sub, could claim a compensation from its client if his agency contract would be terminated and would be replaced by a commissionaire agreennent. ${ }^{3.3}$ Nationall law could provide for such a compensation. ${ }^{34}$ The compensation is based on the increase in earnings, the enrichment which the agent has brought to the principal's enterprise through the creation and development of his customers. The compensation for termination must repay the agent both for the enrichment he caused the enterprise and for the damages suffered by him. ${ }^{35}$ This argument

31 D. Morgan, 'Selling out from the centre', Intemational Tax Review, December January 1997.

32 For example the debtor"s risk and risks relating to the stockkeeping or servicing of garantees.

33 H.K. Kroppen, Funktionsänderung der Vertriebstochtergesellschaft zum Kommissionär, IWB Nr. 23, december 10, 1997, p, 1114.

3.4 Like e.g., Art. 89(b) of the German Commercial code.

35 R. Baldi, Distributorship, Franchising, Agancy (Kluwer, Deventer, 1987), p. 30. 
follows the assumption that a buy-sell sub could be compared to a third company who acts as an agent (because there is an agency agreement). This comparison, in my opinion, fails, because a buy-sell sub cannot be compared to a commission agent. While a commission agent purely acts as an intermediary, and assumes practically no risks, a buy-sell sub buys goods and sell goods on its own account. If, for example, the parent company which sells products to the buy-sell sub, for whatever reason, could not supply any goods, the buy-sell sub incurs no damages, it would only have to find a new supplier.

Dutch law also has provisions dealing with compensation which has to be paid by the company who terminates an agency contract without the agent's consent and before the agency contract expires. ${ }^{36}$ According to Dutch law a commercial agent has, in the case of termination of the agency contract, in some cases a legal right to compensation and in other cases a right to a specific goodwill compensation. ${ }^{37}$ The Dutch tax authorities take the position that a buy-sell sub that is transformed into a commissionaire should be compensated for the loss of profitability (taking into account the risks it no longer assumes), for the marketing intangible and the expenditures connected with entering the new structure. If such a compensation is not received by the former buy-sell sub, the tax authorities can qualify the lack of such compensation as hidden profit distribution and levy withholding taxes and corporate taxes of the former buysell sub. ${ }^{3.8}$

A buy-sell sub could very well create goodwill on its own merits. This will be the case if the buy-sell sub has outstanding marketing and sales performance. Because the buy-sell sub sells the products in its own name, it will create its own regular client record. If the buy-sell sub changes its activities and starts acting as a commissionaire it will still sell the products in its own name but for the account of the parent company. The parent company in this case profits directly from the sub's regular client record. Tax authorities in this case could justly argue that the regular client record, in other words, the goodwill, is transferred to the parent company.

36 According to Article 439, book 7, Dutch Civil Code.

37 F.M. Smit, De agentunovereenkwmst tussen handelsagent en principaal, (W. E. J. Tjeenk Willink, Zwolle, 1990), p. 90.

38 According to an unpublished note of the Dutch Ministery of Finance as a reaction to a case study on commissionaire arrangements, presented at the EMEF meeting on 17 and 18 September 1998 (a meeting between OECD member States and developing countries. 


\subsubsection{Conclusions}

The commissionaire who acts (almost) exclusively for one principal can not be regarded as being an independent agent according to Art. 5(6) OECD Model. The term general commission agent in para. 6 refers to a commission agent who works in substance for a number of clients. So if the exclusive commissionaire does not qualify under Art. 5(6) OECD Model, qualification according to Art. 5(5) OECD Model is appropriate.

Since the altered OECD Commentary extends the basic concept of para. 5 to persons who conclude contracts which are binding on the principal, it has to be determined if the commissionaire concludes binding contracts. I pointed to the Dutch Civil Code and its resemblance to the common law concept of the undisclosed principal. Although it's certainly not a communis opinio I have concluded that in light of the Agency PE analysis, a Dutch commissionaire can be regarded as a person who concludes binding contracts. In the case of a buysell sub whose function is altered into a commissionaire, tax authorities have strong arguments for claiming a transfer of goodwill from the buy-sell sub to the parent company. Although domestic commercial laws provide for some sort of compensation in these cases, I find it decisive that the parent company directly benefits from this change of function.

\subsection{ELECTRONIC COMMERCE AND THE AGENCY PE CONCEPT}

\subsubsection{Introduction}

The Internet is a collection of millions of interconnected computers located throughout the world. It has no central computer or any physical location, but uses hundreds of thousands of computers called "routers" that determine the best route available at the time to transfer data toward their final destination. ${ }^{39}$ The Internet is an exporter's dream- offering the ability to advertise, sell and even distribute on a medium which has the potential to display any product on millions of screens around the globe, and for almost no cost $!^{40}$ Conducting business electronically over the Internet or a private Intranet is called e-

39 T. O'Domnell \& P.A. DiSangro, "United States Tax Policy on Electronic Commerce", Interiax, Volume 25, Issue 12, p. 430.

40 N. Russ, Tax Questions Cloud Intemet Blue Skies For Exporters, published on the Internet at http://www lovotax. ni/tax/onderwerp5/20.html. 
commerce (electronic commerce). To market products through the Internet, companies catalogue their products and services for presentation on a website. Customers from around the world can then visit the site and select and order their products. ${ }^{41}$

Retailing and wholesaling activities on the Internet consist mainly of ordering and paying for goods. Some goods, such as books, computer software, photographs, films, music, and other recorded entertainment, can also be delivered to the consumer in electronic form. ${ }^{42}$ Where the business world embraces the possibilities the Internet provides, tax administrations are worried to what extent their tax jurisdictions are evaded because current tax principles are not adapted to capture e-commerce. The need for extensive discussion about the tax implications of conducting business through the Internet is, I believe, undisputed. Many efforts are already undertaken. A noteworthy report is the discussion paper published by the US Treasury Department in November $1996 .{ }^{43}$ The problems concerning the taxation of Internet transactions are numerous. In this chapter I will focus on the Agency PE concept: does the Agency PE concept have any impact on e-commerce?

\subsubsection{The General PE Concept}

Paragraph 10 of the OECD Commentary on Article 5 states: "But a permanent establishment may nevertheless exist if the business of the enterprise is carried on mainly through automatic equipment, the activities of the personnel being restricted to setting up, operating, controlling and maintaining such equipment." Although this quote primarily refers to vending machines, many authors use this quote when discussing the "fixed place of business concept" in relation to Internet business transactions. ${ }^{44}$ If a foreign company sells its products to domestic buyers, the buyers' state may wish to levy taxes on these sales. The prime method is to analyse if a PE is present. This concept does not specifically

41 M. Vink, Substantive imternationat corporate income tax issues, Caught in the Web: the "Tax and Legal Implications of Electronic Commerce, (FED, Deventer, 1998), p. 58.

$420^{\prime}$ Donnell \& DiSangro, ibid.

43 Department of the Treasury, Selected Tax Policy Implications of Global Electronic Commerce, November 1996, Daily Tax Treasury Documents, Nowember 22, 1996. The orginal report is available on the Internet via fp:/ftp. fedworld.gov/pub/tel/internet.wp. From hereon the report will be quoted as the "Treasury Report".

44 For example, see F.M. Homer \& I. Owens, "Tax and the Web: New Technology, Old Problems", IBFD Bulletin, November/December 1996, p. 517; P.A. Glicklich, S.H. Goldberg, \& H.J. Levine, 'Internet Sales Pose International Tax Challenges', Journat of Taxation, June 1996, p. 326. 
address Internet transactions. Authors refer to para. 10 and conclude that in such a case, the location of the automatic equipment is the main determinant of presence. $^{45}$

The OECD Working Party No.1 (from hereon referred to as OWP) released a draft proposal October 1999 on defining PE's in an e-commerce context. ${ }^{46}$ The OWP cautions that the draft merely reflects the majority views of the working party members and that it should not be viewed as the official OECD opinion. Its aim is to add several new paragraphs to the OECD Commentary.

According to Art. 5(1) OECD Model, a permanent establishment means a fixed place of business through which the business of an enterprise is wholly or partly carried on. The OWP states that a website itself does not involve any tangible property and therefore cannot itself constitute a "place of business", as there is no "facility such as premises or, in certain circumstances, machinery or equipment" as far as only the software and data constituting that website is concerned. The server through which the site is operated is, according to the OWP, a piece of equipment which itself needs a physical location and may therefore, if it is fixed according to Art. 5(1) OECD Model, constitute a "fixed place of business" of the enterprise that operates it.

The OWP, in short, adds four extra arguments to the PE issue, namely (1) automatic equipment that does not require on-site human intervention for its operation may still constitute a $\mathrm{PE},(2)$ computer equipment may only constitute a PE if it is fixed, (3) Internet service providers (ISP"s) will not constitute agents of the enterprises to which the sites belong, and finally (4) the exclusion provision of Art. 5(4), referring to the preparatory and/or auxiliary activities, could also apply to electronic commerce. Pijl concludes that the results from the draft are, to a certain extent, in accordance with the expectations of the business community, but for one major issue, namely the suggestion that for PE recognition in the area of e-commerce the presence of local personnel is not required. $^{47}$

It proves that some current PE conditions are not equipped to deal with ecommerce business transactions. For example, the OWP suggests that computer equipment may only constitute a PE if it is fixed. A server will therefore need to be located at a certain place for a sufficient period of time, in order to become

45 Homer/Owens, ibid.

46 OECD, Document 1999-31502.

47 H. Pijl, OECD and E-Commerce : Clanification or Fundanental Change?, Tax Planning International's E-Commerce, November 1999. 
fixed within the meaning of Art. 5(1) OECD Model. If the location of the provider should be the factor of presence, this could simply be avoided by locating the provider's server outside the country. The Treasury Report ${ }^{48}$ noticed that if the computer server would constitute the foreign company's fixed place of business, PE status would still not be present because of the current "warehouse" PE exception according to Art. 5(4) OECD Model, as the article does not include as a PE, amongst others, the use of facilities solely for storage purposes, display or delivery of goods. Also excluded from the PE definition is the maintenance of a fixed place of business for the purpose of collecting information. All definitions could very well apply to homepages on the Internet.

The OWP states that while the functions performed through computer equipment include activities that form in themselves an essential and significant part of an enterprise's commercial activity as a whole, these would go beyond the activities covered by para. $4 .^{49}$

If the homepage would only act as a kind of shop window, meaning potential buyers can look at the merchandise and obtain additional information, the function of the homepage would be preparatory or auxilliary in light of Art. 5(4) OECD Model. This article could apply in this case; the homepage is a facility "solely for the purpose of display of goods or merchandise belonging to the enterprise". If buyers would be able to buy goods or merchandise stalled and exposed on the homepage, a comparison to mail-order firms is easily made. If a mail-order firm weren't physically present in a state, then it wouldn't have an agent with the authority to conclude contracts in its name, and no general PE or Agency PE should be present. Within the current PE concept, this conclusion would be correct. A homepage could, in my view, be compared to a mail-order catalogue, and could therefore, as a general rule, not lead to a PE status, that is, within the current PE definition.

\subsubsection{The Agency PE and Internet Transactions}

It is interesting to analyse how the Agency PE concept applies to e-commerce via the Internet. There are in fact two intermediaries in relation to e-commerce, the Internet provider and/or the telecommunications provider. The telephone company who supplies the telephone lines for e-commerce, does merely provide a service, and so in my view will not qualify as an agent. The telephone

48 Paragraph 7.2.4.

49 For further thoughts on this issue I would like to refer to R. L. Doernberg \& Luc Hinnekens, Electrowic Commerce and Internotional Taxation, (KKluwer, The Hague/London/Boston, 1999). 
company most certainly has no authority to conclude contracts on behalf of the e-commerce company ${ }^{50}$. Furthermore, according to para. 33 of the OECD Commentary: "The authority to conclude contracts must cover contracts relating to operations which constitute the business proper of the enterprise." The telephone company supplies a service, namely the usage of a telephone line, so that the e-commerce company can promote its products via the Internet. The sales contracts are usually concluded by local distributors, or concluded by the e-commerce company using e-mail, letter or fax.

The Internet provider, however, does raise significant questions concerning the Agency PE status. For example, can an Internet provider be regarded as an agent of the foreign company? If service companies are hired to process orders and to clear payments, could it be concluded that such providers have sufficient authority to bind a foreign enterprise in the activity, which, when exercised habitually, would give rise to the dependent agent status and therefore, to an Agency $\mathrm{PE} ?^{51}$ Does a homepage qualify as an agent? If a customer places a binding order simply by conversing with the server, could the equipment be deemed to give rise to an "agency" which has the authority to enter into contracts on behalf of the enterprise? ${ }^{52}$ These questions and others will be answered in the next section.

\subsubsection{The Provider as an Agency PE?}

According to Art. 5(5) of the OECD Model, an enterprise has an Agency PE if a person is acting on its behalf and has the authority to conclude contracts in the name of the enterprise. As I noticed in $\$ 9.4 .3$, the altered OECD Commentary extends the Agency PE definition to agents who conclude binding contracts. Finally, the authority to conclude contracts must be habitually exercised.

An Internet provider provides a service and gives access to the Internet. If a company has a homepage, buyers of goods can consult the homepage and order the goods. The homepage is in fact space on the provider's server, and the provider certainly has no authority to conclude contracts binding the enterprisein this case the company that has a homepage on the provider's server. The

50 I use the term e-commerce company, meaning an entrepreneur or company that uses the Internet to sell products or provide services.

51 J.D. Cigler, H.C. Burritt \& S.E. Stinnet, Cyberspace: The final frontier for international tax concepts?, published on the Internet at http:/www.wgl-hightech.com/0896/cigler.html.

52 This is a question in D.R. Tillinghast, 'The Impact of the Intemet on the Taxation of International Transactions', IBFD Bulletim, November/December 1996, p. 525. 
provider does not solicit orders, approach potential customers or conclude sales contracts on behalf of the homepage's owner. The homepage can be compared to a shop window, and this is owned by the company who determines fully what information is stalled on the homepage. The provider only focuses on the number of times the homepage is visited, because the charge of a homepage is primarily based on this by an Internet user.

If an Internet provider is hired to process orders and clear payments, still no agency relationship is present, in my view. Processing orders and clearing payments is an automatic process, which is conducted by means of the proper software. In this case, the provider's activities are supportive activities, certainly not based on an authority provided by the enterprise to the provider to conclude binding contracts. Let's not forget that Art. 5(5) OECD Model excludes from the Agency PE concept, persons who undertake activities mentioned in Art. 5(4) OECD Model. Analogous to this article, I conclude that a provider provides the use of facilities, namely the computer space for the homepage and access to the Internet, in order for the enterprise to display or deliver the enterprise"s goods. ${ }^{53}$

If, for the sake of argument, the provider would be considered to be an agent of the enterprise who has a homepage, the provider would most certainly be regarded as an independent agent. According to the OECD Commentary, a person will not constitute an Agency PE if he is independent of the enterprise both legally and economically, and he acts in the ordinary course of his business. ${ }^{54}$ The provider bears the entrepreneurial risk of his Internet activities, he is not economically dependent of one particular enterprise. He offers services to any number of clients, and this creates economic independence from every single customer. According to the OECD Commentary a person is legally dependent if he is subjected to detailed instructions or to comprehensive control.

The provider provides services which by and large are technical services. A customer would usually not be able to issue, for example, detailed instructions. The provider therefore would normally be regarded to be legally independent. And finally, the services the Internet provider provides belong economically to the sphere of its own business operations. In conclusion, the Internet provider is, if he theoretically would be considered to be an agent, most certainly an

53 This could apply if an enterprise offers sofware via the Intemet. After clearing payment, the customer can directly download the software from the homepage or another linked site to its own computer.

54 Paragraph 37 of the OECD Commentary on Article 5. 
independent agent ${ }^{55}$ as thus wouldn't constitute an Agency PE on behalf of an ecommerce company.

\subsubsection{Software Agents}

\subsubsection{Introduction}

A software agent is a program which can be activated by an Internet user simply by clicking on an icon displayed on the homepage of an enterprise. This program has many functions, one being negotiating the terms of contract and also actually concluding contracts between the buyer and the enterprise, being the homepage owner. Doernberg and Hinnekens ${ }^{56}$ discern two kinds of software agents: (1) the static agent, like for example, a mail agent that operates in the background, processing mail arrivals, and (2) the mobile agent which can be sent over the Internet to a remote location where it can then carry out its tasks.

A new application is remote programming which, according to Doemberg and Hinnekens, offers a more efficient agency model. Instead of keeping a connection open, an agent can be uploaded to a server where it resides while completing its tasks. The principal can disconnect from the server and complete other tasks. When the agent has completed the assigned tasks, it can dial-up the principal, deposit information on the principal's computer, and notify the principal that the tasks are completed. ${ }^{57}$ Important is the fact that such a software agent can have the ability to conclude contracts in the name of the enterprise, which could mean that the Agency PE issue could cause taxation in the state where the software agent concluded a contract.

\subsubsection{Software Agents and the Agency PE Concept}

If a software agent acts as a regular agent (an individual), meaning it concludes contracts in the name of the enterprise and thus binding the enterprise, checking if the software agent meets the Art. 5(5) OECD Model conditions, would be in order. This article uses the term "person" in paragraph 5. According to Art. 3(1)(a) OECD Model, a person includes an individual, a company and any other body of persons. A software agent clearly cannot be regarded as a person. On this basis, a software agent, according to the current OECD treaty provision, could never constitute an Agency PE. It should be noted, however, that a

55 Also the conclusion of the US Treasury report, see fn. 440 .

56 Doernberg/Hinnekens, p. 90 .

57 Doernerg/Hinnekens, \$3.7.3.2. 
software agent is a new phenomenon, which presented itself in the late 90 s. Adapting the current Agency PE provision to this new phenomenon would, in light of the essence of the Agency PE provision, be in order. The purpose of the Agency PE provision is that if a foreign enterprise does not have a fixed place of business, but instead, an agent who has the authority to conclude contracts in the name of and binding the enterprise, the foreign enterprise will be taxed in the agent's state.

According to the OECD Working Party (see $\$ 9.5 .2$ ), data and software itself cannot constitute a place of business. Therefore, a software agent can't constitute a fixed place of business according to Art. 5(1) OECD Model. This is not necessary in light of this analysis, because an individual who acts as an agent according to Art. 5(5) could also not have a fixed place of business in the agent's state, and still constitute a permanent establishment, namely an Agency $\mathrm{PE}$, on behalf of the principal.

The OECD Working Party notes that Internet Service Providers (ISPs) will not constitute agents of the enterprise to which the websites belong, because these ISPs will not have the authority to conclude contracts in the name of these enterprises and will not regularly conclude such contracts or because they will constitute independent agents acting in the ordinary course of their business, as demonstrated by the fact that they host the websites of many different enterprises. There is no impediment to apply this line of reasoning to the software agents, but for the fact that they are not persons within the meaning of Art. 3(1)a) OECD Model.

To include software agents in the Art. 5(5) provision, would not be contradictory to the meaning and purpose of this provision. Current Agency PE provisions and also the $\mathrm{OECD}$ Commentary could be applied to software agents if the term person defined in Art. 3(1)(a) OECD Model included software agents.

\subsubsection{Conclusion}

In para. 9.5.1, I proposed the question: does the Agency PE concept have any impact on e-commerce? I would like to conclude the analysis with a definitive "no". A telephone company merely supplies telephone lines so the e-commerce company can indeed conduct its business. It supplies supporting services- not agency services. The same applies to the Internet provider. It provides services, in this case, access to the Internet. They do not conclude contracts on behalf of 
an e-commerce company. The Agency PE concept is based, as I analysed in Chapter VII, on physical persons replacing the original entrepreneur. It does not provide solutions for the usage of hi-tech means, like the Internet, when conducting business. However, the software agent is a practical application of ecommerce, which also does not apply to the current Agency PE concept. Because the software agent performs the same services as an individual agent, it is only justified to the extent that the current Agency PE definition to the software agent.

\subsubsection{Pooling Arrangements}

A pooling arrangement can be set up either with the purpose of profit-pooling and/or and cost sharing. It can be defined as a contractual agreement between two (or more) legally independent enterprises providing for adding together the profits derived or losses incurred by the contracting enterprises to reach a common result. This amount is distributed among the partners according to a commonly agreed formula, while the separate enterprises conduct their own business activities without any capital investment in each others companies. ${ }^{58} \mathrm{~A}$ similar definition can be given as far as cost sharing is concerned. ${ }^{59}$

The overall profits of the pool partners are apportioned among the members using an adequate key of apportionment. An international pooling arrangement which is created in view of integrating group management could possibly generate tax problems in certain countries. ${ }^{60}$ In light of the Agency PE issue, it's important to determine that the pooling arrangement doesn't represent itself externally. If, for example, a third party concludes a contract with one of the parties of the pooling arrangement, there's no doubt whatsoever that the contracting party of the arrangement doesn't legally bind either the group, that is the parties who participate in the pooling arrangement, or one specific pooling partner.

58 E. Lechner, Die Gewimnooling im Ertragsteuerrecht (Profit-pooling in German income taxes), (Peter Dexubner Verlag, Koln, 1985), p. 15.

59 For more on this subject, W.G. Kuiper, (East-West) joint ventures: a special phenomenon in international tax law? (dissertation 1988).

60 F.C. de Hosson, De herstructurering van het Europese concern; Doelstellingen en fiscale gevolgen (I), TVVS $1996 \mathrm{nr} .96 / 1$, p. 8. 
The only Agency PE problem could arise if the state where the pooling partners conduct their business, considers this joint business activity as a kind of partnership. As De Hosson points out ${ }^{61}$ Belgium has the "onregelmatig opgerichte vennootschap onder firma", the irregularly established general partnership. The qualification of a pooling arrangement as a partnership could in some cases indeed lead to an Agency PE status. The Dutch Finance Secretary of State issued a regulation in 1998 , where he recognised that the borderline between a pooling arrangement and a partnership is still not clear. In this regulation the Secretary of State upholds the view that the distinguishing factor in this issue is the fact whether or not both pooling partners aim at enlarging their individual profits by means of entering into a pooling arrangement. If the co-operation of two enterprises does not necessarily lead to higher profits, a pooling arrangement is present, but if the individual profits indeed are increased, a partnership seems more likely. A pooling arrangement per se does not lead to the presence of a physical enterprise and therefore will be neglected for the sake of tax purposes, according to the Dutch Secretary of State. ${ }^{62}$ In the next section I will analyse the possible Agency PE consequences when dealing with partnerships.

\subsubsection{Partnerships}

\subsubsection{Introduction}

Despite different legal definitions of the relationship that constitutes a partnership, three common characteristics can be found. A partnership can thus be defined as:

1 - a contractual relationship between persons;

2 - aimed at the sharing of benefits;

3 - that arise from the joint contribution of resource. ${ }^{6.3}$

Although "partnership" is primarily a legal concept, there are states that define the term partnership in their domestic tax laws. The United States, for example, defines the term "partnership" in sec. 7701(A) IRC as follows:

61 F.C. de Hosson, De herstructurering van het Europese concern; doelstellingen en fiscalle gevolgen (I) (Restructuring European group companies, purposes and tax consequences), TVVS $1996 \mathrm{nr} .9611, \mathrm{p} .8$.

62 Besluit staatssecretaris van Financièn 30 november 1998 , nr. DB98/84l, published in V-N 1.998/58.12.

63 A.H.M. Daniels, Issues in international partnership taxation, (Kluwer, Deventer/Boston, 1991), p. 3. 
"The term partnership includes a syndicate, group, pool, joint venture, or other unincorporated organisation, through or by means of which any business, financial operation, or venture is carried on..."

Limited liability exists if a partner's liability for the debts and obligations of the partnership is limited to the amount of capital he has contributed or agreed to contribute to the partnership. ${ }^{64}$ This generally divides partnerships into general and limited partnerships. This legal form of co-operation exists in many countries, either countries with a common law or civil law tradition. The tax treatment of partnerships differs from country to country. Many tax laws treat the partnership as a fiscally transparent entity. This means that, for tax purposes, the income of the partnership flows directly to its partners. If a partner lives abroad, the question of possible foreign tax liability is imminent. As most partnerships primarily conduct business activities, or in other words are enterprises or companies, Agency PE or general PE qualification will determine whether or not a foreign partner has a limited tax liability with regards to his share of the partnership's profits.

Skaar concludes that as far as the PE issue is concerned, the aggregate theory prevailed over the entity theory. ${ }^{65}$ According to the aggregate theory, the character of income taxation as a tax on the income of individuals plays a central role in taxing partners in a partnership. It is income as reported by the partner that is essential in determining his ability to pay tax. Each partner is thus considered to conduct his own business. ${ }^{66}$ The entity theory, on the other hand, regards the partnership as an accounting entity for computing and reporting business profits for tax purposes. The computation of profits is made at the partnership's level. These profits are then taxed in the hands of the partners, considering the share of the partners. ${ }^{67}$

Application of the aggregation theory, as Skaar refers to, regarding the foreign partner's tax position is correct, in my view. Domestic foreign tax liability legislation and the PE and Agency PE provisions in tax treaties all have the same objective, that the foreign resident or corporation is active in such a way that source taxation could be justified. The aggregation theory treats a

64 J.C. Amico, Introduction to the US income tax system, (Kluwer, Deventer/Boston, 1993), p. 72.

65 A.A. Skaar, p. 171.

66 A.H.M. Daniels, op cit., n. 64, p. 29.

67 llid., p. 24. 
partnership as a pass-through entity, and directly allocates the partnership's profits to each individual partner-a view which concurs with the Agency PE concept.

\subsubsection{Mutual Agency}

Interesting is the fact that common law literature explicitly regards mutual agency as an aspect of the partnership relation. ${ }^{68}$ Mutual agency means that one partner represents the other partner and vica versa. The US Uniform Partnership Act (hereafter the "UPA") describes every partner as "an agent of the partnership for the purpose of its business." ${ }^{69}$ Thus, each partner is not necessarily the agent of each of his co-partners but rather of the partnership itself. One is an agent of an entity, the partnership, rather than of the individuals, the partners. ${ }^{70} \mathrm{I}$ think that this view is an important, or rather, decisive factor when determining whether or not a partner can constitute an Agency PE on behalf of the partnership and/or its partners. From the UPA point of view, the partnership is a separate entity. A partner is a co-owner of the entity, and therefore of the enterprise which the entity conducts. If a partner is considered to constitute an Agency PE on behalf of the partnership, this contradicts the original Agency PE purpose, namely taxing foreign enterprises that conduct domestic business by means of an agent who replaces the original entrepreneur. ${ }^{71}$ The partner conducts his own business, because he owns part of the partnership, and therefore, part of the enterprise. If, however, the partner is considered to represent the partnership sec., the entity, the Agency PE status could be justified if the partner has the authority to conclude contracts which are legally binding the partnership.

A comparison could be made to the agent who is both an employee of the company he represents and a shareholder. In this case he, through his shares, owns part of the company and, at the same time, represents the company by concluding binding contracts. In this case the agent/shareholder could constitute an Agency PE of the company he represents.

68 Reuschlein \& Gregory, $\$ 177$.

69 Paragraph 9 (1) U.P.A.

70 Reuschlein \& Gregory, paragraph 184.

71 I would like to refer to para, 3.2 of this study, where the origin of the Agency PE is discussed. An entrepreneur can conduct his business himself but, if he so wishes, can be replaced by an agent. I"ve named this concept "the replacement theory". This theory, I believe, was the ariginal thought or concept behind the Agency PE. 


\subsubsection{General or Limited Partner}

According to Daniels the mere organising of a partnership does not in itself create a $\mathrm{PE}$. The partnership itself must carry on its activities through a $\mathrm{PE}$, which then must be attributed to the individual partners. ${ }^{72} \mathrm{~A}$ view in line with US tax practice. A nonresident alien individual or foreign corporation is considered to be engaged in a US trade or business if the partnership is so engaged. ${ }^{73}$ In the case of a general partnership the PE would be attributed to each general partner. A limited partner has a limited risk regarding the partnership, his function in the partnership is primarily a financing function. The limited partner usually does not interfere with the day-to-day business of the partnership. The limited partner usually does not conduct the partnership's business.

The Agency $\mathrm{PE}$ is in my view important when considering the foreign limited partner. Daniels, in his thesis, has the same viewpoint:

"It could be argued that due to the agency relationship between the partners, each partner is a dependent agent of the other partner. Consequently, absent a permanent establishment, a foreign partner may still be considered as earning business profits through a Netherlands dependent agent if one of the partners were a Netherlands resident, since such a partner would have an authority to conclude contracts on behalf of the partnership and he would not be an independent agent acting in the ordinary course of his business." 74

Daniels refers to a general partnership as a partner, by means of law, has the authority to represent the partnership. A limited partner usually does not have the legal authority to conclude contracts in the name of the partnership. For example, in Art. 20(2) of the Dutch commercial code (Wetboek van Koophandel), it's stipulated that a limited partner is not allowed to perform management duties even if a volmacht (power of attomey or mandate) is given. This legal standpoint prevents, in my view, that a limited partner is considered to constitute an Agency PE on behalf of the partnership and/or partners. The

72 A.H.M. Damiels, Issues in International Parmership Taxation, (Kluwer, Deventer/Boston, $1991 \mathrm{~J}, \mathrm{p} .90$.

73 H.E. Abrams \& R. JL. Doemberg, Essential of United States Taxation, (Kluwer, The Hague/Deventer/Boston, 1999), par. 29.3.3.4-11.

74 A.H.M. Daniels, op cit, n. 73, see fin. 464, p. 91 . 
limited partner has no authority to conclude contracts in the name and on behalf of the partnership or partners.

\subsubsection{Case Law}

\subsection{U.S Case Law}

In a 1955 court ruling, the W.C. Johnston case, ${ }^{75}$ the taxpayer, Mr. Johnston, was a Canadian partner of a Canadian livestock dealership partnership. Johnston entered into a agreement with a US partnership to ship Canadian cattle to be sold by the US partnership. Johnston was held to be taxable in the US because the Canadian partnership was deemed to have a fixed place of business in the US, by virtue of the US partnership's permanent presence in the United States. According to Robert Williams, in the case of partnerships, application of the agency test is unnecessary since the fixed place of business of the domestic partner or partnership will be attributed to the foreign partner or partnership. ${ }^{76}$

Meanwhile, in the Donroy case $e^{77}$ the US court ruled likewise, that limited partners have a PE in the country where the partnership has its office or other PE-constituting premises. The Unger case ${ }^{78}$ had the same outcome as the Donroy case, a limited partner owned undivided interest in assets of a US partnership and therefore, according to the court, owned interest in the partnership's PE (offices).

\subsection{Dutch Case Law}

In a $1993^{79}$ Dutch Supreme Court (Hoge Raad) ruling, a Swedish company was a limited partner in a Dutch partnership. The Dutch limited partnership had a fixed place of business in the Netherlands which therefore, according to the Hoge Raad, leads to the conclusion that the Swedish limited partner is engaged in a Dutch business through a Dutch PE, if the Dutch limited partnership's fixed place of business can be attributed to the Swedish limited partner. The supreme court ruled that this was the case, because (a) the Dutch limited partnership was

75 W.C. Johmston ws Cmr. 24 T.C. 920 (1955).

76 R.L. Williams, "Permanent establishments in the United States", Tax Lawyer, Vol.29, No.2, p. 342.

77 Donroy Lid. Versus United States, 196 F.Supp 54 (N.D.Cal.1961), affd, 301 F.2d 900 ( $9^{\text {th }}$ Cir 1962). For more on Donroy see $\$ 5.5 .8 .2$. of this study.

78 Robert Unger, 190,015 PHI Memo Tc.

79 Hoge Rad, March 10, 1993 (Nr. 27 786), BNB 1993/227. 
part of the Swedish enterprise and (b) the Swedish company was directly entitled to the profits of the Dutch limited partnership. This ruling stipulates that if the limited partner is an entrepreneur himself (or the company has an enterprise), the limited partner should be treated as an entrepreneur, and should be taxed on his business income, namely his share of the profits of the limited partnership. If a limited partnership is treated, for tax purposes, as a see-through entity, the fixed place of business of the limited partnership can therefore automatically be accounted to its limited partner(s).

One year later, the Hoge Raad confirmed its ruling of BNB 1993/227 in a case of a Belgian limited partner in a Dutch limited partnership ${ }^{80}$. A foreign limited partner in a Dutch limited partnership may be taxed in the Netherlands if the Dutch enterprise is also conducted on behalf of the foreign limited partner. If the limited partner is directly entitled to the profits of the Dutch limited partnership, the enterprise is conducted on the limited partner's behalf.

In a 1995 Dutch Supreme Court ruling, ${ }^{81}$ a Dutch company (BV) did not obtain a foreign tax credit regarding its profits in a German limited partnership, because the BV was not considered to be a limited partner in the German limited partnership. The Hoge Raad ruled accordingly, primarily on the basis of the fact that the BV didn't succeed in proving it received a part of the profits of the German limited partnership on the basis of its capital share.

\subsection{Belgian Case Law}

Although Belgium is not one of the States this study focuses on, a recently published court ruling of the Brussels Hof van Beroep (Court of Appeal) ${ }^{82}$ addresses the issue of the Agency PE concept in relation to partnerships.

A Belgian corporation owns a $25 \%$ participation in a US general partnership which is a limited partner $(38 \%)$ in a US limited partnership. The limited partnership is active in the real estate business. The limited partnership distributed capital from a new mortgage loan it received after paying off the first (old) mortgage. According to US tax law this distribution, due to a refinancing operation, will be treated as a non-taxable advance payment of a future realisation on the increase in value of the real estate. The Belgian corporation, being a general partner, received approximately $\$ 200,000$ from the

80 Hoge Rad, March 23, 1994 (Nr. 29 084), BNB $1994 / 192$.

81 Hoge Raad, April 19, 1995 (Nr. 3119 ), BNB 1995/248.

82 Hof van Beroep, April 30, 1998, published in De Fiscale Koerier 1998, p. 316. 
partnership. The Belgian corporation accounts this amount as a capital gain, and reserves a certain amount of the $\$ 200,000$ in view of future US capital gains tax.

According to the Belgium-U.S. DTC, accrued capital gains situated in the other State may be taxed in the other State, in this case the US. The Belgian tax authorities did not agree with this tax treatment of the $\$ 200,000$ and states that the amount must be qualified as business profits, and the Belgian corporation lacks a PE in the US. The consequence of this view would be that the $\$ 200,000$, according to the Belgium-US DTC, must be taxed in the resident State, namely Belgium. The Court of Appeal ruled in favour of the Belgian corporation and, relevant to the topic under discussion, stipulated that the Belgium corporation, as a general partner in the US partnership, had a US Agency PE according to Art. 5(5) of the Belgium-US DTC. ${ }^{83}$ Where according to US and Dutch case law, a general partner is supposed to have a fixed place of business and therefore a general $\mathrm{PE}$, the Belgian court determines that the Belgian general partner had a US Agency PE, provided that the general partner is co-liable to the contracts the US managing partner concludes.

Commentator M. van Keirsbillck ${ }^{84}$ supposes that the court in fact made a mistake, and should have ruled that the Belgium corporation has a general PE in the US. He does recognise that this issue is a pure theoretical issue, because either way, a US PE is present.

This issue, in my opinion, is not a pure theoretical issue. It could be the case that a partnership has a fixed place of business in State A and the managing partner concludes contracts in State B. If a general partner is a resident of State $\mathrm{C}$, it could be the case that, according to the Belgian court ruling, the general partner (State C) is considered to have an Agency PE in State B because the managing partner concludes contracts in the name of the partnership and the general partner of State $\mathrm{C}$ is co-liable to these contracts. I see no reason why this view would not be correct. If the general partnership is considered, for tax purposes, to be a see-through or transparent entity, all the profits are directly allocated to the partners. It's completely in line with the Agency PE concept to allocate the profits of the partnership"s agent to the partners.

\subsubsection{Conclusion}

If a general partner has the authority to conclude contracts in the name of the partnership, and he habitually exercises that authority, he binds the partnership

83 This provision is almost identical to Art. 5(5) OECD Model.

84 In his comment on this ruling, published in De Fiscalle Koerier 1998, p. 316. 
and thus the owner's of the partnership, both general and limited partners. Both US and Dutch case law show that if the partnership has a general PE or Agency $\mathrm{PE}$ it must be attributed to its partners, both general and limited partners.

A limited partner does not have the authority to conclude contracts in the name of the partnership, and can"t therefore constitute an Agency PE on behalf of the partnership. If, however, a limited partner does conclude contracts in the name of the partmership, despite lacking the proper legal authority, and the partnership afterwards validates the contract, an Agency PE should be constituted, provided the limited partner does conclude the initially unauthorised contracts habitually, and these contracts are validated by the partnership afterwards.

\subsubsection{The Insurance Agent}

Specific case law ${ }^{85}$ on the Agency PE concerns agents who represent foreign insurance companies. An insurance agent issues policies, collects premiums and possibly pays claims. The main question concerning the Agency PE is whether or not the insurance agent is a dependent or independent agent of the insurance company.

A way to avoid Agency PE status of the insurance agent is, in light of the OECD Model, to claim that the agent is an independent agent who fully complies with the conditions laid down in Art. 5(6) OECD Model. ${ }^{86}$ This would imply that the insurance agent works for several insurance companies and can be considered to be legally and economically independent and acts within the normal course of the business of his peers (the insurance agents). Another way is to stipulate home office approval of each issued policy by the agent. This would imply that the agent has no authority to conclude contracts in the name of the insurance company, and therefore doesn't comply to an essential condition of the Agency PE provision (concluding contracts "in the name of" the enterprise).

Because an insurance company may pursue large-scale business activities in a state without being taxed, a special provision for insurance companies is included in the UN Model treaty. The OECD Model does not contain a special provision dealing with the insurance agent. The OECD Commentary states in para. 39:

85 For example the Tasei Case (104 TC No.27, may 2, 1995), the Dutch insurance ageni (HR 28 june 1995) and Hoge Raad 13 January 1971 (BNB 1971/43).

86 For example the Taisei Case, a US tax court decision. 
"The decision as to whether or not a provision along these lines should be included in a convention will depend on the factual and legal situation prevailing in the Contracting States concerned. Frequently, therefore, such a provision will not be contemplated. In view of this fact, it did not seem advisable to insert a provision along these lines in the Model Convention."

The UN Model treaty does contain a special provision dealing with the insurance agent and the Agency PE issue. Art 5(6) UN Model reads:

"...an insurance enterprise of a Contracting State shall, except in regard to re-insurance, be deemed to have a permanent establishment in the other Contracting State if it collects premiums in the territory of that other State or insures risks situated therein through a person other than an agent of an independent status to whom paragraph 7 applies."

The Agency PE activities are the collecting of premiums and the insuring of risks, reinsurance is explicitly excluded. Reinsurance is deemed not to be a core business activity, although reinsurance from a commercial point of view is insurance business. ${ }^{87}$ A further conclusion is that all the activities could escape Agency PE status if they are conducted by a broker, general commission agent or any other agent of an independent status.

There are States who consistently include, in their bilateral tax treaties, special provisions concerning the Agency PE status of insurance agents. Belgium is one of those States. In, for example, Belgium"s double taxation convention with the Netherlands, in Art. 5, para. 5 (which is an Art. 5, para.6, OECD-like provision), the next sentence is added to the independent agency clause:

"This rule does not apply to an agent who primarily acts on behalf of, at the most, two insurance companies and who has the authority to conclude contracts in the name of that company or companies, and habitually exercises this authority."

This is a provision which is completely in line with the basic Agency PE concept. Agents who work exclusively or almost exclusively for one principal are not likely to be considered to be independent agents. Only the insurance

88 Translated from the original Dutch text. 
agent who has the authority to conclude contracts in the name of the insurance company could, if he would not be an independent agent in the light of Art. 5(6) OECD Model, be considered to constitute an Agency PE on behalf of the insurance company. Therefore, the Belgian provision does not add anything to the basic Agency PE concept. It could nevertheless be argued that this provision does provide clarity in the case of insurance agents who sell policies on behalf of foreign insurance companies. Clarity, in the sense that foreign insurance companies cannot avoid Agency PE taxation by using a so-called independent insurance broker, if that broker works exclusively for one or two insurance companies. 


\section{Allocation of Profits}

\section{1}

INTRODUCTION

When a foreign enterprise has a domestic agent who meets the conditions set in Art. 5, para. 5, OECD Model, it shall be deemed to have an Agency PE. The previous chapters all dealt with this problem; when an agent qualifies as an Agency PE and when he doesn't. In this chapter that very question is not the issue. This chapter deals with the following step: if indeed there is an Agency PE, what are the profits that should be allocated to the Agency PE of the foreign enterprise?'. According to Daniels, the allocation of profits in the case of an Agency PE is quite a brainteaser. ${ }^{2}$ There is not much case law on this subject available, and the few books which are written on the PE issue, do not analyse the allocation of profits. ${ }^{3}$

It is important to quantify the net income allocated to the PE, because it will not only be subjected to foreign taxation but it will also influence the principal's taxable base in his state of residence. The incurred foreign taxes on the PE's net income can be credited against the local tax liability or the PE's net income can be exempt from the principal's taxable base according to the exemption method. ${ }^{4}$ Whether the credit method or the exemption method is applicable, this differs from State to State. The Netherlands, for example, uses the exemption method for profits derived through a PE. In all the double taxation treaties the Netherlands has concluded that with other States, application of the exemption method is guaranteed for all Dutch residents.

The allocation of profits to the Agency PE should not be treated differently than the allocation of profits to a "general" PE. The concepts of the PE and the Agency

I I am indebted to Rutger Goedel who participated in this part of the research by writing a thesis on this subject (Universiteit Mastricht, November 1997).

2 A.H.M. Daniels, Winstallocatie bij internationale samenwerkingsterbanden, in Internationalle winstallocatie (Gouda Quint, Arnhem 1996), p. 35.

3 A.A. Skaar, Permanent Estabishment; John Huston \& L. Willams, Permanent Establishments, a plaming priner, Both do not discuss the allocation of profits in the case of a PE.

4 H. Becker, "The determination of income of a permanent establishment or branch" "Intertax 198911 , p. 12. 
PE are based upon the same premises, namely the mechanism to involve a foreign entrepreneur in taxation if that entrepreneur is economically active in the source country, whether by using a physical establishment (PE) or by using a permanent agent (Agency PE). The allocation of profits should be determined within the boundaries of the generally accepted allocation concept. The latter concept is rooted in Art. 7 of the OECD model treaty.

This chapter does not contain an extensive transfer pricing study. Instead, l've analysed in which way, according to current international tax law, profits could be allocated to an Agency PE. The following paragraphs will examine Art. 7, OECD Model concerning the taxation of business profits. I will briefly deal with the methods used to determine the income of the Agency PE and the concept of functional analysis. In the fifth section of this chapter, I will narrow the discussion down to the allocation of profits to an Agency PE. In paragraph 10.5.4.3, I discuss a 1933 League of Nations report because it introduces and discusses the commission or fee method and the independent dealer price method. By using an example in paragraph 10.6, the issues are further explained. I also pay brief attention to "stripped buy and sell subsidiary" companies before offering my final analysis and conclusions.

\section{2}

\section{ARTICLE 7 OECD MODEL}

Art. 7, OECD Model deals with the question of which State can levy taxes on business profits. Rules for ascertaining the profits of an enterprise which is trading with an enterprise of another State, when both enterprises are members of the same group of enterprises, are dealt with in Art. 9, OECD Model. (This discussion will focus on the Agency PE, so Art. 9, OECD Model will not be the topic of discussion. ${ }^{5}$ ) The basic rule, according to Art. 7, para. 1, OECD Model, is that an enterprise of one State shall not be taxed in the other State unless it carries out business in that other State through a PE situated therein. ${ }^{6}$ If there is a PE, the last sentence of Art. 7, para. 1, OECD Model states: "...the profits of the enterprise may be taxed in the other State but only so much of them as is attributable to that permanent establishment."

This rule forbids application of the force-of-attraction rule. This rule is applied by some States, and means that the presence of a PE gives the PE-State the freedom to

5 The Agency PE is an internal part of the enterprise, not an associated company.

6 OECD Commentary on Articte 7, para 3. 
tax the income from all domestic sources, whether or not this income can be attributed to the PE.?

There are basically two methods to determine the profits of a PE: the direct method and the indirect method. The direct method allocates profits as if the PE were an entirely separate enterprise under conditions and at prices prevailing in the ordinary market. The indirect method uses as a point of departure the overall worldwide profits of the enterprise. These overall profits are being attributed to the PE on the basis of a distributive code, also referred to as fractional apportionment. ${ }^{8}$

\section{3}

\section{THE INDIRECT METHOD}

Under this method, the actual accounts of the PE do not form the basis of determining profit; rather, the profits of the global enterprise are determined and apportioned among its members using a rational criterion. ${ }^{9}$ In fact, all parts of the enterprise are assumed to have contributed to total profits. According to the OECD commentaries, the criteria commonly used for allocation can be grouped into three main categories: those which are based upon the enterprise's receipts, its expenses, or its capital. The first category covers allocation methods based on turnover or on commission, the second concerns wages and the third on the proportion of the total working capital of the enterprise allocated to each branch or part. ${ }^{10}$ This assumes that the profits of the enterprise's various parts, are equal to the total profit of the enterprise. The consequence of this method is that total profits of the (group) enterprise always lead to profits for each separate part of the (group) enterprise. Art. 7, para. 4, OECD Model makes it clear that this method may continue to be employed by a Contracting State if it has been customary in that State to adopt it.

This can occur even though the figure arrived at may at times differ, to some extent, from that which would be obtained from separate accounts, provided that the result can fairly be said to be in accordance with the principles in the article. ${ }^{11}$

If an enterprise produces uniform or homogeneous products or services, the indirect method could be applied. Only in this case it's possible to find the proper key for the apportionment of the total profits. The OECD commentary mentions

7 S. van Weeghel, Artikel 7 (Winst wit onderneming), Ch. MII.7, Handboek Internationaal Belastingrecht, (Delwel, The Hague, loose-leaf ed.).

8 Klaus Vogel on Double Taxation Conventions

9 E.W. Madole, "Agents as permanent establishments under U.S. income tax treaties", Tax Management International Joumal, June 10, 1994.

10 OECD Conmentary on Article 7, para 27.

11 OECD Commentary on Article 7, para 25. 
that it may, for example, be appropriate to make an apportionment of total profits by reference to:

- premiums received from policy holders in each of the countries (insurance companies);

- the proportion of total working capital (banking/financial concerns);

- turnover (enterprises providing services with a high profit margin). ${ }^{12}$

\subsection{THE DIRECT METHOD}

\subsubsection{Introduction}

The OECD Model clearly favours application of the direct method. Art. 7, para. 2 states:

"...there shall in each Contracting State be attributed to that permanent establishment the profits which it might be expected to make if it were a distinct and separate enterprise engaged in the same or similar activities under the same or similar conditions and dealing wholly independently with the enterprise of which it is a permanent establishment."

While Art. 7, para. 1, OECD Model contains the general rule concerning allocation of business profits, Art. 7, para. 2, OECD Model contains the main allocation rule, namely the direct method, treating a PE as if it were a separate enterprise. The embodied fictional independence here epitomises the neutrality principle, which according to Hamaekers, underpins the arm's length principle. Taxpayers with a controlling interest in a company are placed in the same position as other taxpayers through application of the arm's length principle which neutralises the advantage of the former. ${ }^{13}$

The basis for the allocation of profits will be the trading accounts of the PE, which are commonly available if onlly because a well-run business organisation is normally concerned to know what is the profitability of its various branches. ${ }^{14}$ Para. 12.1 of the OECD Commentary on Art. 7 mentions the possibility for tax authorities to correct the trading accounts of the PE when those trading accounts are based on internal agreements that reflect purely artificial arrangements instead of the real economic functions of the different parts of the enterprise.

12 OECD Commentary on Article 7, para 27.

13 H. Hamaekers, "The Arm's Length Principle and the Role of Comparables", IBFD Bulletin, December 1992, p. 603.

14 OECD Commentary on Article 7, para 12. 
The OECD Commentary describes the general principal as follows:

"...the general rule should always be that the profits attributed to a permanent establishment should be based on that establishment's accounts insofar as accounts are available which represent the real facts of the situation. If available accounts do not represent the real facts then new accounts will have to be constructed, or the original ones rewritten, and for this purpose the figures to be used will be those prevailing in the open market."15

The reference in this quote to the figures prevailing in the open market, corresponds to the comparable uncontrolled price method. If no comparable prices are available because, for example, an enterprise produces a unique product, other allocation methods can be used, such as the cost-plus method or the resale-minus method.

\subsubsection{Allocation Methods}

The comparable uncontrolled price method (CUP) determines the intercompany price by using the price of another transaction equal to the transaction under evaluation, but only if the transaction is concluded with at least one unrelated party; meaning a party not related or associated to the enterprise where the CUP is being applied. ${ }^{16}$ Many authors agree that the CUP is the best method, provided that comparables prices are available. The conditions that must be met to qualify as a comparable in the United States are rather strict, while they are more flexible in many other countries as are the OECD guidelines.

According to U.S. Treasury Regulations $\$ 1.482-1(\mathrm{~d})(\mathrm{I})$, for example, determine that while a specific comparability factor may be of particular importance in applying a method, each method requires analysis of all of the factors that affect comparability under that method. Such factors include (i) functions; (ii) contractual terms; (iii) risks; (iv) economic conditions; and (v) property or services. ${ }^{18}$

15 OECD Commentary on Article 7, para 14.

16 R.P.F.M. Hafkenscheid \& A.T.G.M. Hosman, Transfer pricing in het Nederlands belastingrecht, 2nded. (Fed, Deventer, 1998), p. 85 .

17 H. Becker, 'The Future of Transfer Pricing", IBFD Bulletin, November/December 1996, p. 536.

18 Treas.Reg. $\$ 1.482$ authorizes the IRS to allocate gross income, deductions, credits, and other allowances among two or more organizations, trades, or businesses under common ownership or control whenever it determines that this action is necessary "in order to prevent evasion of taxes or clearly to reflect the income of any of such organizations, trades, or businesses." 
A comparable transaction involving an arm's length price is the best method of determining intercompany prices. An arm's length price is the ultimate price in a transaction negotiated by unrelated parties, each acting in their own self-interest, being the basis for a fair market value determination. Because the direct method treats the $\mathrm{PE}$ as an independent company, the direct method is more than appropriate. If comparables are not available, working backwards from the ultimate price charged to an unrelated purchaser may produce an arm's length price. This price is then reduced by an appropriate mark-up representing the amount out of which the reseller would seek to cover his costs and make a profit. ${ }^{19}$ The reseller, in this case, is obviously the PE. This method is known as the resaleminus method, a method probably most useful when it is applied to marketing operations.

Alternatively, the cost-plus method determines the correct profits by means of working forward from the actual manufacturing cost incurred by the manufacturing company. ${ }^{20}$ In this case the PE profits are determined by the production costs plus a margin of gross profits. This method raises problems assessing costs and the appropriate mark-up for profit. It is most likely appropriate as a determining criterion in specific situations ${ }^{21}$, though it may also be useful as a means of verifying provisionally acceptable prices after other methods have been applied. $^{22}$

\subsubsection{Functional Analysis}

An important part of the arm's length definition is functional analysis. This means that the determination of the arm's length price between unrelated parties must take into account the functions performed by the associated enterprises. Functional analysis is thus important to establish if an uncontrolled transaction is a true comparable; it is even more important when the comparables cannot be found. In this case the taxpayer and/or the tax authority look into other methods to establish the arm 's length price. ${ }^{23}$

19 Transfer Pricing and Multinational Enterprises, (OECD, Paris, 1979), para 56.

20 R.L. Doemberg, Intemational Taxation, (West Publishing Co., St. Paul, Minn., 1.989), p. 149.

21. For example when semi-finished products are sold, or when different entities have concluded joint facility agreements, or long-term buy-and-supply arrangements, or when the PE essentially performs a tole of subcontractor.

22 OECD, Transfer Pricing Guidelines for Multinational Enterprises and Tax Administrations, (OECD, Paris, 1995), \$2.34, p. Il-11.

23 OECD Transfer Pricing Report 1995, \$1.20, p. I-9. 
The principle of functional analysis is well reflected in the instructions issued by the Canadian tax authorities, which clarifies that "a functional analysis will identify and evaluate, with respect to a given product or product line, the role and contribution of each member, including the economic risk assumed and the degree of responsibility for engineering and production, continuing research, management and administration, marketing and customer services" (Canadian Information Circular, para. 15). ${ }^{24}$

The profits of each enterprise have to be determined, and the prices used between each enterprise form the basis of the profit assessment. The prices between the head office and the PE are also based upon the function they each perform and also according to the financial risks they each bear. A general commission agent who does not bear risk concerning a stock of goods, will obviously charge his principal differently than a general commission agent who does. Because the head office and the PE are one and the same legal entity, their mutual transactions have to be regarded as "as-if business transactions". These "as-if business transactions" are based upon the arm's length principle.

\subsubsection{Introduction}

An enterprise that manufactures certain goods or commodities does this in its State of domicile or in other states. Then, the manufactured products could be sold in other States. Concerning the Agency PE, the enterprise engages a dependent agent who sells its products in the name of and on behalf of the enterprise. The selling price charged to customers contains, in fact, two gross types of compensation for the enterprise (i.e. the principal): compensation for production and development of goods, and compensation for sales activities. The principal's profit margin, derived from the actual selling price, is divided into production profit and sales profit.

The production profit compensates the capital that the principal primarily invested in the State of domicile. This profit should therefore be allocated to the State of domicile. The sales activities take place in the Agency PE's State, and (part of) the sales profits should therefore be allocated to the Agency PE's State.

24 Transfer Pricing in the absence of comparable market prices, Cahiers de Droit Fiscal International, Volume LXXVIIa, (Kluwer, Deventer/Boston, 1992). 


\subsubsection{Independent Dealer or Commission Agent}

If the profits gained through an Agency PE have to be determined by treating the Agency PE as an independent company, according to the direct method, this can only mean that the Agency PE should be compared to either the independent dealer or the independent agent (e.g., the general commission agent). Both parties are independent and perform services comparable to an Agency PE. I would like to point out that my starting point is the basic Agency PE in the following analyses, meaning primarily an agent who sells product from its principal in the name of and on behalf of the principal. If agents who perform other services- like manufacturing agents- qualify as Agency PEs, the basic profit allocation method could be used, but the basis of the "extra" services they perform should be adjusted. If, for example, a manufacturing agent processes the goods of the principal and sells the products (after processing) in the name of the principal and on behalf of the principal, the manufacturing agent could qualify as an Agency PE according to Art. 5, para. 5, OECD Model. ${ }^{25}$ The allocation of profits to the Agency PE should take place on the basis of the functions the Agency PE performs.

An independent dealer (in Dutch referred to as wederverkoper) buys products from a foreign company (the principal) and sells them to customers at its own risk, and he assumes credit risks and the risk of stock obsolescence.

A commission agent arranges sales on behalf of a principal, and either signs the contract on behalf of a principal or the principal himself signs the contract. The commission agent receives a commission from the principal, normally calculated as a base percentage of sales, but sometimes also on a cost-plus basis. ${ }^{26}$ The general commission agent works for any number of principals and could be considered to be an independent agent.

On this point it is appropriate to bear in mind that the OECD commentaries state that if the conditions of Art. 5, para. 5, OECD model are met, and so an Agency PE exists, all of the Agency PE activities are taxable. This applies not only to the profits that arise with regard to concluding contracts in the name of the principal. ${ }^{27}$ Article 7, OECD Model states that if an enterprise carries on business through a $\mathrm{PE}$, the enterprise's profits may be taxed in the PE's State, but only so much as is attributable to that PE. Article 7, OECD Model therefore also applies to the foreign enterprise that has a domestic Agency PE.

25 For more on this issue, see $\$ 8.2 .7 .3$ of this study.

26 D. Morgan, 'Selling out from the centre', International Tar Review, December/January 1997.

27 OECD Commentary on Article 5, \$34. 


\subsubsection{Different Opinions}

An enterprise and its Agency PE can be regarded as associated enterprises. However, the question would be: what comparison should be made? If dealings between a foreign enterprise and its domestic Agency PE don't differ, according to Art. 9, OECD Model, from dealings between independent enterprises, what kind of enterprises are comparable to an Agency PE? An independent dealer or general commission agent could be compared to the Agency PE.

In the Dutch literature on the Agency PE, a discussion arose about these issues. Daniels pointed out when comparing the Agency PE to the independent dealer, this would imply that the Agency PE should apply the fiction of buy and resale, in other words, the Agency PE is assumed to buy the goods from its principal and then sells them on to the customer.

The issue then would be determining the arm's length price charged by the head office to the Agency PE. According to Daniels this would lead to a higher PE profit allocation than when the comparison is made to an independent agent. ${ }^{28}$ Meanwhile, Van Brunschot argues that the Agency PE should be compared to the general commission agent, being an independent agent. The reason is that Art. 7 , para. 2 stipulates that the profits allocated to a PE should be the profits that would have been received if the agent would have been an independent entrepreneur, who would find himself in almost the same situation as the agent. ${ }^{29}$

However, Van Raad disagrees with van Brunschot on several occasions, and points to specific problems when addressing the Agency PE as an independent agent. ${ }^{30} \mathrm{~A}$ transfer of risk is at hand when a company sells its products through an independent dealer in comparison to sales through a dependent agent (Agency PE). The independent dealer usually can bear the debtor's risk, stock risk or transport risk, all depending on the actual functions he performs. If the company uses a dependent agent to sell its products in its name and at its own risk, the company bears all the entrepreneurial risks concerning the sales. Van Raad concludes that a general commission agent runs less entrepreneurial risk than the independent

28 A.H.M. Daniels, Winstallocatie bij internationale amenwerkingsverbanden, p. 37.

29 Hoge Raad, 15 June 1988, Rolno. 24 881, BNB 1988/258. I ve andysed this court case in $\$ 6.8$ of this study.

$30 \mathrm{~K}$. van Raad, De vaste vertegenwoordiging en de bepaling van de daamee behaalde winst, Gielebundel, (Kluwer, Deventer, 1990), p. 522. 
dealer and that a choice between the two comparisons should be made, depending on the actual activities of the Agency PE. ${ }^{3 !}$

This last argument is consistent with the OECD view. In the 1995 OECD Transfer Pricing Report, the OECD states that a tax administration's examination of a controlled transaction ordinarily should be based on the transaction actually undertaken using the accepted allocation methods. ${ }^{32}$

\subsubsection{Allocation Methods}

\subsubsection{Cost-Plus Method}

Cost-plus (see $\$ 10.4 .2$ ) is a method where a certain profit margin is placed on the cost price. Problems occur when determining production costs and an appropriate profit margin. According to Hafkenscheid and Hosman ${ }^{33}$, when determining a profit margin one should first look at the margin used in transactions with third parties. If such figures are not present, one should focus on transactions with associated enterprises that work on a cost-plus basis, and what profit margin is known. Such figures are not often available, and application of this method can be troublesome because the profit margin can only be estimated. Another problem with the cost-plus method and the Agency PE is the fact that real costs constitute the basis of profit allocation. As stated in $\S 10.5 .1$., only (part of) the sales profits should be allocated to the Agency PE's State. By using real (production) costs, also (part of) the production profits would be allocated to the Agency PE's State, a situation which is, in my opinion, not just.

In a 1985 resolution, the Dutch Secretary of State stipulated that the costs which must be assignment to the cost basis are, in general, all costs which are directly connected to the activities of the Dutch enterprise. Costs like housing costs, office costs, salaries and employee costs paid by the employer. ${ }^{34}$ The Agency PE could be the Dutch enterprise, and therefore, the agent's commission (comparable to the salary of an employee) could also be allocated to the Dutch Agency PE. This is not as straightforward as it may seem, because internal costs between the principal and

31 Van Raad in his note on Hoge Raad, 28 June 1995, Rolno. 29 435, BNB 1996/108c. For more information on this court case, I suggest referring to $\$ 6.9$ of this study.

32 OECD, Transfer Pricing Guidelines for Multinational Enterprises and Tax Administrations, (OECD, Paris, 1995), \$1.36, p.1-15.

33 R.P.F.M. Hafkenscheid \&. A.T.G.M. Hosman, Transfer pricing in het Nederlands belastingrecht (Transfer pricing according to Dutch tax law), $2^{\text {nd }}$ ed. (FED, Deventer, 1998), p. 88.

34 Resolution of April 25, 1985, Nr. 084-2737, BNB 1985/196. 
the Agency PE could be regarded as internal costs which are usually not deductible for the Agency PE, like interest or royalties paid by the Agency PE to its principal.

Para. 17.6 of the OECD commentary on article 7(3) states:

"Where the main activity of a permanent establishment is to provide specific services to the enterprise to which it belongs and where these services provide a real advantage to the enterprise and their costs represent a significant part of the expenses of the enterprise, the host country may require that a profit margin be included in the amount of the costs."

Art. 17(3) OECD Model contains clarifications concerning the expenses of a permanent establishment. The commentary in para. 17.6 contains a rule which can also be applied to Agency PE's. It recognises the fact that if an Agency PE performs specific duties towards its principal, the Agency PE's State may allocate a certain profit margin in relation to the costs incurred. This could imply a case for applying the cost-plus method regarding an Agency PE. But still, the problem with the cost-plus method is (1) calculating the correct costs and (2) determining a correct profit margin.

\subsubsection{Resale-Minus Method}

The resale-minus method uses, as a basis for allocating profits, the price the Agency PE charges to (unassociated) customers- a real arm's length price. As in the cost-plus method, the next step would be to determine an arm's length profit margin which can be allocated to the Agency PE. Compared to the cost-plus method, I think that the resale-minus method is more appropriate for approaching the Agency PE than the cost-plus, because it eliminates one major problem- the calculation of costs.

The ultimate resale price is fixed and known, so this could serve as a basis for proper allocation. The elimination of the production profits can be achieved by establishing a profit margin customary for unassociated third parties. This markup, used by third parties, shall be generally based upon the resale price which should already contain a production-profit margin. 


\subsubsection{The Commission or Fee Method and the Independent Dealer Method}

In 1933, Ralph Jones introduced the commission or fee method and the independent dealer price method. ${ }^{35}$ This study was part of a large League of Nations research project under the auspices of the Fiscal Committee of the League of Nations, and the purpose of that enquiry was to provide the Committee with the necessary documentation for framing a draft for the Convention for the Prevention of the Double Taxation of Business Income. The Jones' report was the last report in a series of five.

The commission method is based on the assumption that goods are consigned to the sales branch in the same manner as they would be to an independent commission agent. The essential feature of a consignment as distinguished from trading is the retention of title by the consignor. Goods are placed in the custody of a consignee who has the power to sell them and to transfer title to the purchaser, but until the time of sale, ownership is held by the consignor. The consignee's remuneration for handling the goods may take the form of a commission on sales, or possibly a profit measured by the excess of the selling price over a price agreed upon by the consignor and the consignee. Since the consignee usually receives a commission, this method of business transaction is often referred to as the commission basis. The commission method, however, may be used when an agent makes sales for direct delivery to the customer without handling the goods himself.

The ease with which branch earnings may be determined constitutes the principal advantage of this method. Since, under this method, the earnings of a branch depend upon its turnover rather than the margin between the cost and sale price of merchandise, there is no problem with inventory valuation. The net profit of a branch may be computed by a reasonable rate of commission compared to sales receipts and deducting branch expenses. ${ }^{37}$

The commission or fee method is appropriate for buying, certain kinds of processing, and selling establishments. According to this method the commission or fee should be such an amount as would induce an independent person to undertake the business with the expectation that a normal or reasonable volume of

35 R.C. Jones, Allocation Accounting for the Taxable Income of Industrial Enterprises, Taxation of foreign and National Enterprises (Volume V), (League of Nations, Geneva, 1933).

36 Hans Aufricht, Guide to League or Nations Publications, (Columbia University Press, New York, $1951)$, pp. 244-245.

37 Ralph C. Jones, op cit, n. 35, p. 27. 
business will yield a return on the branch capital commensurate with the degree of risk inherent in the business. The commission basis is the simplest of all methods, according to R.C. Jones. It automatically eliminates the problem of unrealised profits in branch inventories. It provides a more regular branch income less subjected to extreme fluctuations than the income of branches which "buy" the product. In doing this, it assigns income to a branch proportionate to the volume of business done, rather than in accordance with the price fluctuation of commodities. When prices are falling, the income of the branch may not decrease proportionally so long as the volume of business continues; also, when prices are rising, the income of the branch would not necessarily increase unless there were an increase in the volume of business. ${ }^{38}$

Meanwhile, the independent dealer price method treats the Agency PE as a separate business and accounting unit. Dealings between the head office and the Agency PE are kept on a commercial basis by the use of regular market or dealer prices in all inter-branch billing. The prices charged to sales branches may be the same as prices charged to independent dealers. Factory prices fixed in this manner will be satisfactory if a substantial portion of the total business is transacted through dealers who are charged a uniform price, and who operate on the same scale as the branches. If uniform prices are not used or if the operating conditions of branches and dealers differ widely, dealer prices do not furnish a very reliable guide for the determination of inter-branch prices. ${ }^{39}$ It is important to note that this method is only called for if, for any reason, the commission basis is not applicable or desirable in computing the branch income. ${ }^{40}$ In general, the commission basis is a simple and effective method, whereas the independent dealer method only works if comparable prices (prices charged to independent dealers) are available.

10.6 EXAMPLE OF APPLICATION OF THE DIRECT METHOD

In this paragraph, I will further analyse the allocation issue regarding the Agency PE, with an example. My starting point is $\mathrm{Y} \mathrm{GmbH}$, a German manufacturer of cosmetics that sells their perfume in the Netherlands through a 
Dutch independent agent $(Z)$. $Z$ receives a fair market value commission of $10 \%$ of turnover. ${ }^{41}$

$\begin{array}{lr}\text { Turnover Y GmbH (Netherlands) } & 2000 \\ \text { Total production costs } & -900 \\ \text { Gross margin } & 11.00 \\ \text { Commission Z } & -200 \\ \text { Sales costs Z } & -80\end{array}$

Because Y GmbH uses an independent dealer for its sales in the Netherlands, it would obviously not be liable to Dutch taxation, since the Dutch independent agent would be considered to be an independent agent according to the GermanDutch double taxation convention. ${ }^{42}$ The profits Y GmbH generates through the independent agent are taxed fully in Germany. The Dutch independent agent is taxed in the Netherlands for its own profits, namely 200 minus 80 sales costs, resulting in a taxable profit of 120 . Meanwhile, Y GmbH has a taxable profit of 900 ( 1100 gross margin minus 200 commission of $Z$ ).

In this case, if Y GmbH had used a dependent agent, for example an employee who performs the same duties as the independent agent, the profits of $Y \mathrm{GmbH}$ obviously would be different compared to the previous callculation. I assume that $\mathrm{Y} \mathrm{GmbH}$ would pay its employee the same salary (80) as the independent agent pays his employee.

$\mathrm{Y}$ GmbH would incur the same sales costs as $\mathrm{Z}$ would. This would result in a taxable profit of $\mathrm{Y}$ GmbH of:

Turnover Y GmbH

Total production costs

Gross margin

Sales costs

Overall profit
2000

$-900$

1100

$-80$

1020

The increase in profit, (1020 minus 900) 120 , is exactly the same as the profit of the independent agent. However, because $\mathrm{Y} \mathrm{GmbH}$ is supposed to have an Agency PE in the Netherlands, some part of its profit should be allocated to the Netherlands. The issue here is the fact that the Dutch agency (managed by $\mathrm{Y}$

41 This example is based on Daniels" example in Winstallocatie bij internationale santerwerkingsverbanden, see fin 421 , p. 35 .

42 Art. 2 (2)(d) of the German-Dutch treaty is fully based on its OECD model counterpart. 
GmbH's employee) should receive a fair market value commission. ${ }^{43}$ In this case the fair market value commission- or in other words the arms length commission- is known, namely the $10 \%$ commission the independent agent received. In fact the $10 \%$ commission can be regarded as being a comparable uncontrolled commission. Therefore, the Agency PE profits would be:

Comparable uncontrolled commission 200

Sales costs

Agency PE profits

This, in fact, is an application of the commission or fee method, simple and straight forward, but only because a fair market value commission is known (the $10 \%$ ). The overall tax burden is the same in the before-mentioned two cases, namely when using (I) an independent agent or when using (II) a dependent agent. The only difference is that in case I, Y GmbH is taxed for 900 and the independent agent is taxed for 120 (total of 1020), where in case II Y Gmbh is taxed for 1020 (900 in Germany and 120 in the Netherlands by means of its Agency PE). With both options 120 should be allocated to the Netherlands and 900 should be allocated to Germany.

If in this example, $Y$ Gmbh would have had a Dutch subsidiary, the outcome would be the same. If $Y$ BV would sell the products on behalf of, and in the name of Y Gmbh, then Y Gmbh would be deemed to have a Dutch Agency PE. If the Dutch subsidiary performs the same duties as the independent agent, the foreign company (in this case the foreign parent company) would have to pay the same commission as it would have paid the independent agent. This would lead to the following Agency PE profits:

Comparable uncontrolled commission 200

Commission Dutch subsidiary $\quad-200$

Agency PE profits

With this example, the 200 will be taxed by the Dutch subsidiary as a taxable profit. The 80 sales costs would leave a taxable profit of 120 . Y GmbH would be taxed in Germany for 900 . If the Dutch subsidiary would sell the products in its own name, and would further meet all the requirements of an independent agent, Y GmbH would not have a Dutch Agency PE. Y GmbH would still have to pay its Dutch subsidiary a fair market value commission of $10 \%-$ Art. 9 , 
OECD Model obviously applies, and again the outcome would be the same as in the case of the Dutch subsidiary acting as an dependent agent. The conclusion would be that if a subsidiary company is used as an agent, a fair market value commission would be the proper basis for the allocation of profits. The allocation of profits between two States (the principle State "Germany" and the agency State "the Netherlands") would be the same whether the subsidiary acts an a dependent agent or whether it acts as an independent agent.

Also when the agent is not a subsidiary company, it does not make a difference if the agent is a dependent agent or an independent agent, that is, when analysing what portion of profits should be allocated to the principal's State or the agent's State. The taxable profits are only divided over different persons. Interesting is the alternative raised by David Morgan, who introduces the "stripped buy and sell subsidiary". 4 .

\subsection{THE STRIPPED BUY AND SELL SUBSIDIARY}

A stripped buy and sell subsidiary is a subsidiary company with reduced functions. The subsidiary only buys goods when it makes third party sales. The margin of the buy/sell subsidiary is based on the difference between the sale and purchase prices. If the functions of the buy and sell subsidiary are the same as the functions of a commissionaire or general commission agent, the arm's length remuneration would be the same..$^{45}$ Morgan points to the benefits of using a buy and sell subsidiary, namely the possibility to choose how much of the activity and risk will be transferred out.

Concerning the allocation of profits issue, the use of a buy-sell subsidiary would make no difference. Whatever functions the subsidiary performs, the link should always be made to the fair market value commission. As my example in the previous paragraph showed, the connection with the fair market value commission safeguards any discrepancies. A stripped buy-sell subsidiary should receive a "stripped" commission, in other words, a fair market value commission according to the actual functions that the subsidiary performs.

44 D. Mongan, "Silling out from the centre", International Tax Review, December/January 1997.

45 lbid., diagram 5 , fin 453 . 


\subsection{CONCLUSION}

Within the generally accepted allocation method, the direct method, the allocation of Agency PE profits should take place according to this method. The basis for this assessment is a functional analysis, recognising the actual function of the Agency PE as the leading principal when allocating PE profits.

In an Agency PE a "dependent" agent sells products in the name of the foreign enterprise. The agent doesn't bear any entrepreneurial risk, all the profits he generates are fully on behalf of the principal. The agent receives some kind of commission for the work he performs on behalf of his principal. Because the direct method treats the Agency PE as if it operates as an independent company, the commission the agent receives should be a fair market value commission. Perhaps like independent companies do, the principal and the agent should create a sort of commission agreement where they formalise their business relationship and state explicitly who bears what kind of risk and what the fair market value commission would be. If States would require a written commission agreement in all agency situations (either in the case of a dependent or independent agent or when using a subsidiary company as an agent), perhaps the discussion, when deciding the allocation issue, would focus solely on the question of what fair market value commission would be appropriate.

The direct method requires that the Agency PE be treated as if it were an independent company, and that it should be compared to an independent company. Bearing in mind functional analysis, this last statement should be refined in a way that the Agency PE should be compared to an independent agent performing the same functions as the Agency PE. So, when determining what a fair market value commission should be, functional analyses, perhaps based on a written commission agreement, should compare what services the agent actually performs, and compare them to an independent agent performing the same services. This would not be an easy task, because in all cases a proper comparison can't be made. As the 1933 League of Nations report by Ralph C. Jones shows, the commission or fee method is a relatively simple, effective and just allocating method very well suited for the Agency PE. The basis for allocation is the arm's length commission or fee that is received by the Agency $\mathrm{PE}$, compared to an independent agent who performs the same duties. After deducting the direct sales costs, a fair apportionment of profits can be taxed by the Agency PE's state. 
If a foreign enterprise would use an unassociated agent, the commission it would pay that agent would obviously qualify as being a fair market value commission, because an unassociated agent would only act if he receives proper commission. The unassociated agent could well act as an Agency PE if he sell the products on behalf of, and in the name of a foreign enterprise. So, also in this case, the fair market value commission should form the basis of the allocation of profits when using an agent. If a foreign enterprise would use its subsidiary company as an agent, Art. 9, OECD Model requires that both companies act at arm's length. The subsidiary company should receive a fair market value commission for the services it performs. 


\section{Summary and Conclusions}

\subsection{THE HISTORICAL DEVELOPMENT OF THE AGENCY PE (ART. 5, OECD MODEL)}

\subsubsection{The Dependent Agency Clause}

The Agency PE was originally introduced in the 1899 double taxation convention between Prussia and Austria/Hungary. It primarily focussed on the presence of a permanent establishment. The person conducting the business through the PE could be either the entrepreneur or owner himself, but also his permanent representative (ständiger Vertreter). I would like to call this permanent representative "an agent" because the permanent representative had the same powers- or authority - as the owner. The entrepreneur could be fully replaced by his agent who could conduct business in the same way as the owner could. This would mean that the agent must have had the authority to conclude contracts in the name of the entrepreneur. Although I have found no evidence which proves this conclusion, because the agent was fully authorised to replace his principal, this conclusion seems very plausible. I named this element of the Agency PE concept "the replacement theory". In the 1922 German Income Tax Act, the German domestic Agency PE definition was altered, compared to the 1899 treaty definition. As a result, a physical PE was no longer required. It was explicitly determined that an Agency PE could have the same status as a general $\mathrm{PE}$ if the agent had the authority to conclude contracts.

The 1927 League of Nations draft convention stated that agencies shall be regarded as permanent establishments. In the commentary section, the LON listed the term "permanent representatives" as possible PEs. In my view, the LON used the German domestic Agency PE provision as their example. The 1929 report of the LON's Fiscal Committee made a significant contribution to the current Agency PE definition. It was considered that an agent who had the authority to conclude contracts on behalf of his principal and habitually exercised this authority, constituted an Agency PE. This agent, according to the committee, concludes contracts which would legally bind the principal. These Fiscal Committee standpoints were adopted by the International Chamber of Commerce. At their 1931 conference an Agency PE was recommended exactly 
like the Agency PE definition construed by the Fiscal Committee in their 1929 report.

Because of World War II, the Agency PE definition did not further develop for a couple of years. The 1943 Mexico and 1946 London Model Conventions marked the next step. These conventions did not contain an Agency PE provision in the actual treaty text. The commentaries nevertheless contained comments on the Agency PE: an agent who has the power to conclude contracts on behalf of the principal shall be deemed to constitute a Agency PE. Four criteria were listed sufficient for a foreign enterprise to be deemed to have an Agency PE. An Agency was present if the agent:

(1) had the power to bind the enterprise; or

(2) was an employee of the enterprise; or

(3) maintained a stock of goods; or

(4) his rent and/or office expenses were paid by the enterprise.

The OEEC, predecessor of the OECD, issued a report including a model convention in 1958 which also dealt with the PE concept. In this OEEC Model Convention the Agency PE definition is as follows:

"A person acting in a Contracting State on behalf of an enterprise of the other Contracting State- other than an agent of an independent status to whom paragraph 5 applies- shall be deemed to be a permanent establishment in the first-mentioned State if he has, and habitually exercises in that State, an authority to conclude contracts in the name of the enterprise, unless his activities are limited to the purchase of goods or merchandise for the enterprise."

The phrase "authority to conclude contracts" is based upon the view that an Agency PE should be limited to dependent agents of those enterprises which, in view of the scope of their agent's authority or the nature of their agent's business dealings, take part to a particular extent in business activities in the other State. It was not a general authority, because the committee felt it unlikely that any dependent agent would have completely unfettered authority to conclude contracts. In the following decade, the 1963 OECD Model copied the OEEC Agency PE definition. The OECD commentary declares in para. 15 that the Agency PE is strictly limited to those agents who are legally and economically dependent upon the enterprise for which they carry out business dealings. 
In the 1977 OECD Model the Agency PE definition is contained in Art. 5, para. 5, which states:

"Notwithstanding the provisions of paragraphs 1 and 2, where a person- other than an agent of an independent status to whom paragraph 6 applies-- is acting on behalf of an enterprise and has, and habitually exercises, in a Contracting State an authority to conclude contracts in the name of the enterprise, that enterprise shall be deemed to have a permanent establishment in that State in respect of any activities which that person undertakes for the enterprise, unless the activities of such person are limited to those mentioned in paragraph 4 which, if exercised through a fixed place of business, would not make this fixed place of business a permanent establishment under the provisions of that paragraph."

In paragraph 31 of the commentary it is stated that the enterprise is in fact involved in business activities in the agent's state when the agent: "has sufficient authority to bind the enterprise's participation in the business activity in the state concerned." In my view, the phrase "authority to bind the enterprise" refers to a legal connection. The enterprise is bound by contract, according to civill law, when the agent concludes contracts in the name of the enterprise. If that is the case, the enterprise is legally a contract partner concerning the contracts concluded by its agent. The enterprise's quality as contract partner can certainly be regarded as the above-mentioned required actual involvement in the agent's state.

The current 1995 OECD Model provision has the same Agency PE provision as in the 1977 OECD Model. An important change in the Agency PE concept is instigated by the March 1994 modified commentary. On the basis of the commentaries the agent does not necessarily have to enter into contracts literally "in the name of" the enterprise. The paragraph equally applies to an agent who concludes contracts which are binding on the enterprise, even if those contracts are not actually in the name of the enterprise.

\subsubsection{The Independent Agency Clause}

The independent agency clause (like e.g., the current Art. 5, para. 6, OECD Model) originates from English domestic tax law. The 1915 UK Finance Act contained a provision which exempted certain persons from the Agency PE status: the broker and general commission agent. The reason for this exemption was an economical one, the UK authorities were afraid that the quantity of 
business being done in the City of London by stockbrokers- who bought and sold on behalf of foreign entrepreneurs enormous quantities of investments and securities on the London Stock Exchange-could be diminished because of the general Agency PE provision in the Finance Act. This also applied to the commodities business. A broker was essentially an intermediary acting for both parties through a contract, primarily bringing both parties together. The general commission agent was a commission agent who worked for clients in a manner common to brokers, meaning he worked for any number of clients.

The Finance Act 1925 adhered to the same principles embodied in the Finance Act 1915. Section 17, para. 1, of the Finance Act 1925, reads:

"(1) Where sales or transactions are carried out on behalf of a non-resident person through a broker in the ordinary course of his business as such, and the broker satisfies the conditions required to be satisfied for the purpose of this section, then, notwithstanding that the broker is a person who acts regularly for the non-resident person as such broker, the non-resident person shall not be chargeable to income tax in the name of that broker in respect of profits or gains arising from those sales or transactions."

Para. 3 of this provision stated that "broker" includes "a general commission agent". A new condition was added to the exemption rule: the broker or general commission agent must act in the ordinary course of their business.

Later that decade, the 1929 report of the League of Nation's Fiscal Committee also exempted the broker and general commission agent from the Agency PE definition. The broker was exempted because he merely brings parties together. The commission agent was exempted because he acted in his own name for any number of clients.' The Fiscal Committee did not use the term "general commission agent" but simply "commission agent".

The Mexico (1943) and London (1946) conventions contained a clause exempting the foreign entrepreneur who had business dealings in another state through an agent of genuinely independent status like the broker and commission agent. The same arguments were used in the Mexico Model Protocol as in the 1929 Fiscal Committee report for these exclusions. They were, however, treated as one group: the agent of a genuinely independent status. In my view, this is not correct, the broker merely brings parties together

1 LON, Document C.516.M.176.1929. II, Geneva, October 26, p. 4. 
and therefore cannot be considered to be an agent. The fact that both the 1929 Fiscal Committee report and the Mexico and London Model refer to the commission agent as an agent who acts in his own name for the principal, point to a clear civil law interpretation. In the Mexico Model the authors added to the group of independent agents the abbreviation etc. (broker, commission agent, etc.). This points to the fact that the authors didn't want to limit this group of independent agents merely to brokers and commission agents.

The OEEC 1958 Model Convention contained the following provision:

"An enterprise of a Contracting State shall not be deemed to have a permanent establishment in the other Contracting State merely because it carries on business in that other State through a broker, general. commission agent or any other agent of an independent status, where such persons are acting in the ordinary course of their business."

This provision is almost the same as the current Art. 5, para. 6 OECD Model provision. While the Mexico Model used "commission agent", the OEEC Model reintroduced the term "general commission agent". Important is the fact that this provision, next to the broker and general commission agent, adds the phrase "any other agent of an independent status". Later, the 1963 OECD Model copied almost exactly the provision of the 1958 OEEC Model, and the 1977 OECD Model text concerning the independent agent also showed little difference with its 1963 counterpart.

However, the commentary of the 1977 OECD Model was fully rewritten. Para. 36 introduced a two-fold test in order to determine if an agent is in fact an independent agent. The agent will come into the scope of Art. 5, para. 6 in the OECD Model if:

"(a) he is independent of the enterprise both legally and economically, and

(b) he acts in the ordinary course of his business when acting on behalf of the enterprise."

In other words, an agent is legally independent if he is not subjected to detailed instructions or comprehensive control by his principal, and an economically independent agent is an agent who bears entrepreneurial risk. In the 1995 OECD Model provision, the para. 6 treaty text or commentary wasn't altered. 

US AND THE NETHERLANDS

\subsubsection{Domestic Law}

German tax law uses the term ständige Vertreter ("permanent representative"), for an Agency PE, and it contains a specific article (Art. 13 Abgabeordnung) which defines the domestic Agency PE. If the conditions of Art. 13 of this German General Fiscal Law (Abgadeordnung) are met, limited tax liability on the basis of Art. 49 of the German Income Tax Act is established. An Agency PE is a (legal) person who: (1) conducts business for an enterprise, (2) acts durably and permanently and (3) must comply with the instructions of the principal.

This Agency PE concept has a broader range than the OECD Model provision. If a foreign entrepreneur has a German agent who must comply with his business instructions (sachliche Weisungsgebundenheid), an Agency PE (ständige Vertreter) is present. This could also apply to an independent agent. The sachliche Weisungsgebundenheid nevertheless implies that the principal must actually and frequently intervene in the agent's activities on behalf of the principal.

The Agency PE concept according to Dutch tax law is comparable to the German concept. Dutch tax law uses a Dutch term for permanent representative, namely vaste vertegenwoordiger. However, there's one major difference with the German Agency PE concept: there is no condition which resembles the German sachliche Weisungsgebundenheid. The Netherlands basically applies their Agency PE treaty definition. Both Germany and the Netherlands seem to put more emphasis on the legal aspects concerning the Agency PE issue. Does the agent have the (legal) authority to conclude contracts in the name of the principal? The phrase "in the name of", as demonstrated in Chapter II, is a typical civil law term which functions perfectly in a civil law system.

Meanwhile, the UK taxes non-residents if they trade in the UK. The concept of a UK representative has been created, which means "the branch or agency through which the trade is conducted". Comparably, the US has a similar system for taxing non-resident aliens and/or foreign corporations: the US trade or business concept. The UK and US Agency PE domestic concept is- in my view- primarily based upon an economic standpoint. It basically doesn't matter in what legal way a foreign corporation conducts its US business, if the US 
activities have such a substance that the activities could be determined as being US trade or business, then US taxation is appropriate. It's relevant to note that both the UK and US have a legal system based upon common law, and according to it, the leading principle of agency is: "he who acts through another, himself acts"2. This means that it won't make any difference if a foreign entrepreneur conducts the US business himself, or if his US agent is conducting the US business. The actions of the agent are assigned to the principal. This results in a purely economical assessment of the Agency PE concept: is the foreign entrepreneur conducting business in the US?

\subsubsection{Treaty Application}

All of the countries analysed, by and large, adhere to the OECD view of the Agency PE concept. The only major difference is the fact that both the UK and US prefer to omit the term "in the name of" from the Art. 5, para. 5 OECD Model Agency PE definition. England, from the mid 90 s onwards, consequently uses the following phrase in the general Agency PE definition: "....and habitually exercises in a Contracting State the authority to conclude contracts on behalf of the enterprise..." In comparison, the 1996 US Model Income Tax convention uses a slightly different term, namely: "...and habitually exercises in a Contracting State an authority to conclude contracts that are binding on the enterprise..."

Therefore, the UK Agency PE definition is prompted from an economic standpoint; as long as the agent is conducting the business of the foreign entrepreneur, an Agency PE is present. This definition gives more weight to the economic substance of the business, instead of the legal way in which the business is conducted. In my view, this is contrary to the US definition, where a legal concept (binding contracts) is used - one which is broadly known and applied in US legal practice, and also known in other common law jurisdictions.

\subsection{CONCLUSIONS}

The founding fathers of the Agency PE, late-1800s German municipalities, used a legal concept for the Agency PE. A foreigner could only be taxed if his permanent agent had the same legal authority as the foreign entrepreneur himself.

2 Bowstead on Agency, fifteenth edition by F.M.B. Reynolds (Sweet a Maxwell, London, 1985). 
The current treaty term "agent" is therefore one which should primarily be interpreted through legal interpretation. It's a legal concept which has its own specific meaning, dependent upon each particular legal system, either based on a common law or civil law concept. The March 1994 alterations of para. 32 OECD commentary refer to a clearer and, perhaps to some extent, broader Agency PE concept. The Agency PE condition- "concluding contracts in the name of the enterprise"-- is strictly a civil law concept. The altered OECD commentary points to an Agency PE concept where an agent concludes contracts which are legally binding, the foreign enterprise qualifies as an Agency PE. The term "binding contracts" is a concept, which is clear and applicable to both common law and civil law jurisdictions. On this issue, the legal definition should be decisive.

The Agency PE definition should therefore be adjusted as follows:

\begin{abstract}
"Notwithstanding the provisions of paragraphs 1-3, where a person -other than an agent of independent status to whom paragraph 6 appliesis acting on behalf of an enterprise, and has, and habitually exercises, in a contracting State an authority to conclude contracts binding the enterprise, that enterprise shall be deemed to have a permanent establishment in that State."
\end{abstract}

The independent agent could have the authority to conclude binding contracts. If the agent, however, can be considered to be both legally and economically independent and can be considered to be acting within the normal course of his

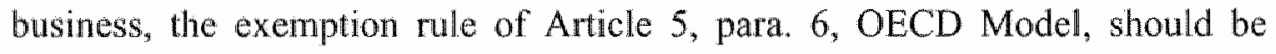
applied, and Agency PE status is not justified.

If an agent, either considered to be dependent or independent, does not have the authority to conclude binding contracts, the agent can not constitute an Agency $\mathrm{PE}$ of the foreign enterprise. Nevertheless, in absence of the required authority, according to Article 5, para. 5, OECD Model, it could still be the case that the agent concludes binding contracts.

Although perhaps the foreign enterprise actually signs the contract which is negotiated by the agent, in some jurisdictions the agent will be regarded as having concluded a contract legally binding the foreign enterprise. The decisive test in determining the Agency PE issue should always be the legal criterion of concluding binding contracts. If an agent only has the authority to negotiate contracts up to a certain point, the Agency PE status of the agent is justified if the agent did create a legal binding of the foreign enterprise. A contrario, if the agent negotiated a contract, but the applicable law does not qualify the activities 
of the agent as having concluded a binding contract, Agency PE status of the agent is not justified.

Although the agent perhaps does not sign the contract, does not actually conclude the contract, if the foreign enterprise (the principal) can be held legally responsible for the business activities of its agent, it could be said that the agent binds the principal, and therefore Agency PE status could be justified.

The independent agent who works exclusively for one principal is in my view not an independent agent. The OECD Model formulates three conditions concerning the independent agency status: the agent must be legally and economically independent and act in the normal course of his business. German domestic tax law emphasises the extent of control a principal can exercise over his agent (sachliche Weisungsgebundenheid). Although this condition can only be found in German domestic tax legislation, it does emphasise the relationship between the principal and agent. A principal obviously has the right to instruct, to some extent, his agent. It is the amount of freedom the agent has when operating his business which makes him independent or not. This aspect refers to the legal independency condition according to the OECD Model. If a principal can, and also actually does, interfere with the day-to-day business of the agent, the agent cannot be regarded as independent.

The economically independent agent is not dependent on one principal concerning his profits or income. For example, if an agent receives ninety percent of his profits from commissions received from one single principal, the agent is economically dependent on this particular principal. An independent agent could be considered to be economically independent if he acts on behalf of any number of principals or clients. If a principal has an agent who is almost fully dependent concerning the agent's income, the principal can exercise control over the agent, simply because the agent relies for his income, too a large extent on that principal. The agent's independence, in this case, is not secured.

The Art. 5, para. $6 \mathrm{OECD}$ term "general commission agent" refers to a broad category of commission agents who generally work for any number of clients. This implies that the commission agent, who works exclusively for one (or few) principal(s), is not a "general" commission agent within the meaning of para. 6 . This does not automatically mean that this agent therefore is an agent according to para. 5. If the exclusive agent does not conclude binding contracts- in civil law countries this means concluding contracts in the name of the principal- the agent does not qualify as an Agency PE and therefore, the principal can not be taxed. 
The condition that independent agents must act within the ordinary course of their business must be applied in an objective way. It should be decisive what fellow agents that belong to the same group of agents undertake. I would like to add to this conclusion that, this comparison should primarily be limited to territories. I think it is not justified to compare, for example, a Dutch insurance agent with an Italian or perhaps even an Indian insurance agent. This should be obvious because firstly, domestic taxation will determine if a foreign entrepreneur has a domestic Agency PE. Secondly, examining the treaty provisions is necessary. Because the agent's state is the source state, and as the state wants to determine if an Agency PE is present, comparing groups of agents in the agent's state is a logical approach.

In the independent agency clause, based on Art. 5, para. 6 OECD Model, the term "broker"can be omitted. A broker does not conclude contracts; he merely brings parties together. The broker does not meet the general Agency PE conditions, according to Art. 5, para. 5 OECD Model.

In the broadest meaning of the word, electronic commerce is doing business via the Internet. In chapter IX I proved that the current Agency PE is not equipped to deal with this way of doing of business. Economically the trend is clear; using agents of flesh and blood is becoming more unnecessary. Consumers and businesses can obtain goods or services directly via the Internet. For example, a hotel or airline ticket can be obtained directly from the hotel owner or airline, and the travel agent is no longer needed-a trend which is irreversible. Companies can save costs if they are no longer dependent upon their worldwide network of agents.

The main issue concerning the Internet is always how the different States can obtain their fair share of profits from electronic commerce. I think that the Agency PE concept cannot offer a solution to this problem. Because of the fact that by doing business through the internet the use of agents of flesh and blood becomes redundant, indicates that the Agency PE concept will lose importance. 


\section{Samenvatting}

Art. 5, lid 5, van het OESO modelverdrag bepaalt dat indien een vertegenwoordiger van een buitenlandse onderneming de bevoegdheid heeft om voor rekening en risico van de onderneming contracten af te sluiten op naam van de onderneming, en regelmatig van deze bevoegdheid gebruik maakt, de onderneming een vaste vertegenwoordiger (VV) c.q. een vaste inrichting heeft in de staat waar de vertegenwoordiger actief is. Deze status impliceert dat de onderneming die een dergelijke vertegenwoordiger in een bepaald land actief laat zijn, door dat betreffende land in de belastingheffing kan worden betrokken voor een deel van de winsten die de vertegenwoordiger voor de buitenlandse onderneming genereert.

Van de vaste vertegenwoordiger status is uitgezonderd, onder voorwaarden, de onafhankelijke vertegenwoordiger. Art. 5, lid 6, OESO modelverdrag, bevat deze uitzonderingsbepaling die stelt dat geen vast vertegenwoordiger zijn de makelaar, commissionair en overige onafhankelijke vertegenwoordiger, mits zij in hun normale bedrijfsuitoefening handelen.

Het concept van de VV wordt niet alleen gehanteerd in belastingverdragen maar ook in nationale belastingwetgeving. Een van de bijzondere aspecten van het vaste vertegenwoordigersconcept is het gegeven dat in feite gebruik is gemaakt van een juridisch concept om het fiscale concept vorm te geven. Bijzondere aandacht in deze studie krijgen de belastingstelsels van een viertal landen: Duitsland, Het Verenigd Koninkrijk, de Verenigde Staten en Nederland. De historische ontwikkeling van het vaste vertegenwoordigersconcept is nadrukkelijk in deze studie opgenomen.

In hoofdstuk 2 heb ik het juridische vertegenwoordigingsleerstuk geanalyseerd op grond van twee grote rechtsstelsels, namelijk civil law (zoals bijv. Nederland en Duitsland) en common law (zoals bijv. het Verenigd Koninkrijk en de Verenigde Staten). Vertegenwoordiging volgens civil law is voornamelijk gebaseerd op de leerstukken van de directe en indirecte vertegenwoordiging. Een vertegenwoordiger bindt zijn principaal als hij overeenkomsten afsluit op naam van zijn principaal, de zogenaamde directe vertegenwoordiging. De indirecte vertegenwoordiging houdt in dat een vertegenwoordiger overeenkomsten afsluit op eigen naam maar voor rekening en risico van zijn principaal. In dit geval worden er twee overeenkomsten afgesloten, namelijk die tussen de vertegenwoordiger en zijn principaal en die tussen de vertegenwoordiger en de derde partij. 
Een common law vertegenwoordiger hoeft niet perse overeenkomsten op naam van zijn principaal af te sluiten wil hij zijn principaal kunnen binden, een vertegenwoordiger bindt zijn principaal als hij als een vertegenwoordiger handelt.

In hoofdstuk 3 staat Duitsland centraal en is bijzondere aandacht besteed aan de historische ontwikkeling van de VV. De originele gedachte achter de VV was dat het eigenlijk voor de belastingheffing geen verschil zou moeten uitmaken of een onderneming door de eigenaar zelf wordt geëxploiteerd of dat hij een plaatsvervanger aanstelt die dezelfde bevoegdheden heeft als de eigenaar zelf, en daarom de eigenaar volledig kan vervangen. Duitse nationale belastingwetgeving maakt ook gebruik van het VV-concept alleen is de nationale definitie van de VV ruimer dan die van de VV uit het OESO model verdrag. Als een vertegenwoordiger gehouden is de zakelijke instructies van de principaal volledig op te volgen, kan hij als een VV wordt aangemerkt, zelfs als hij verder voldoet aan alle vereisten van de onafhankelijke vertegenwoordiger.

Het concept van de onafhankelijke vertegenwoordiger conform ons huidige art. 5, lid 6, OESO modelverdrag, is ontwikkeld en ontstaan in het Verenigd Koninkrijk (V.K.) en wordt in hoofdstuk 4 geanalyseerd. Het Verenigd Koninkrijk introduceerde in 1915 anti-misbruik wetgeving die er toe leidde dat indien buitenlandse ondernemingen in het Verenigd Koninkrijk zaken deden d.m.v. vertegenwoordigers onder voorwaarden deze ondernemingen in het V.K. belastingplichtig werden. De drie belangrijkste voorwaarden waren dat er een nauwe band moest zijn tussen de buitenlandse onderneming en haar Engelse vertegenwoordiger, de buitenlandse onderneming substantiële controle moest hebben over haar Engelse vertegenwoordiger en, ten slotte, er geen of minder winsten gegenereerd werden dan redelijkerwijs verwacht kon worden.

Omdat het gevaar bestond dat door deze wetgeving buitenlandse ondernemingen het V.K. zouden gaan mijden, introduceerde men een uitzonderingsbepaling voor buitenlandse ondernemingen die zaken deden in het V.K. via makelaars, general commission agents of andere niet-bevoegde vertegenwoordigers. Handel via deze groep "onafhankelijke" vertegenwoordigers leidde niet tot belastingplicht in het V.K. De general commission agent was een vertegenwoordiger die op commissiebasis voor klanten werkte en zijn activiteiten niet beperkte tot èèn principaal of een geringe groep principalen. In 1925 werden de voorwaarden voor de onafhankelijke vertegenwoordiger verder uitgebreid. De huidige voorwaarde dat onafhankelijke vertegenwoordigers moeten handelen in de normale uitoefening van hun bedrijf werd toen geïntroduceerd. 
De Verenigde Staten (hoofdstuk 5) betrekken buitenlandse ondernemingen in de belastingheffing als deze betrokken zijn in een US rade or business. Dit concept van de beperkte belastingplicht is niet gebaseerd op het VII of VV concept. Toch bevat de Internal Revente Code een bepaling die heel sterk overeenkomt met art. 5, lid 5 \& 6, OESO modelverdrag. De fiscale verdragspolitiek van de Verenigde Staten is grotendeels gebaseerd op het OESO modelverdrag.

In het Amerikaanse modelverdrag uit 1996 werd echter een belangrijke wijziging aangebracht in het VV-artikel. De voorwaarde dat de VV overeenkomsten moet afsluiten "op naam van" de buitenlandse onderneming werd gewijzigd. Dit element werd vervangen door de voorwaarde dat de VV overeenkomsten moet afsluiten die de buitenlandse ondernemingen binden. Alhoewel nadrukkelijk werd verklaard dat deze wijziging geen groot verschil met het OESO modelverdrag betekent, ben ik van mening dat dit wel het geval is.

De Treasury Regulations bevatten een bepaling ( $\$ 1.864-7$ (d)(3)(iii)) die stelt dat indien een onaflankelijke vertegenwoordiger exclusief of vrijwel exclusief voor èèn buitenlandse onderneming werkzaam is, bewezen moet worden of deze betreffende vertegenwoordiger ook werkelijk een onafhankelijke vertegenwoordiger is.

In de Taisei Case werd het belang van het OESO commentaar benadrukt bij het interpreteren van verdragsbepalingen. In deze zaak kwam verder naar voren dat ook onafhankelijke vertegenwoordigers onderworpen kunnen zijn aan een bepaalde mate van controle en zich moeten houden aan instructies c.q. wensen van de principaal, zonder dat dit betekent dat zij daarom als een VV worden aangemerkt.

De ontwikkeling van de vaste vertegenwoordiger in Nederland (hoofdstuk 6) sluit nauw aan op de Duitse ontwikkeling. In belastingverdragen baseert Nederland zich op het OESO modelverdrag.

In de Nederlandse jurisprudentie is het cargadoorsarrest (BNB 1988/258) van belang. In deze uitspraak bepaalde de Hoge Raad dat het mogelijk is dat een specifieke vertegenwoordiger voor een bepaalde buitenlandse principaal als een VV wordt beschouwd, terwijl m.b.t. activiteiten voor een andere buitenlandse onderneming de vertegenwoordiger als een onafhankelijke vertegenwoordiger kan worden beschouwd. Een n.m.m. juiste conclusie aangezien de vaststelling of er wel of niet sprake is van een VV per buitenlandse onderneming bepaald moet worden, het betreft immers de beperkte belastingplicht van individuele ondernemingen. 
In een uitspraak van de Hoge Raad van 28 juni 1995 (BNB 1996/108c) inzake een Engelse verzekeraar, verwierp de Hoge Raad het standpunt van het Ministerie van Financiën dat indien een Nederlandse vertegenwoordiger voor èn buitenlandse onderneming verschillende activiteiten verricht, een splitsing in deze activiteiten kan worden aangebracht, zodanig dat voor bepaalde activiteiten deze vertegenwoordiger als een VV kan worden beschouwd en voor andere activiteiten niet (omdat m.b.t. deze activiteiten de vertegenwoordiger als een onafhankelijke vertegenwoordiger kan worden aangemerkt). Het betrof hier, voor de duidelijk, allemaal activiteiten voor een en dezelfde onderneming. De Hoge Raad bepaalde dat in een dergelijk geval er een totale beoordeling moet worden gemaakt die er toe kan leiden dat de vertegenwoordiger of als een VV wordt aangemerkt of als een onafhankelijke vertegenwoordiger.

In hoofdstuk 7 wordt de historische ontwikkeling van de vast vertegenwoordiger besproken vanaf de Volkenbond rapportages in de twintiger jaren tot en met het huidige OESO modelverdrag. In het Volkenbond rapport uit 1929 kwam 0.a. naar voren dat een makelaar geen VV kan zijn aangezien een makelaar alleen maar partijen bij elkaar brengt, een makelaar is geen vertegenwoordiger. Een n.m.m. juridische interpretatie die juist is. De term general commission agent is in het Volkenbond rapport uit 1929 in het Frans vertaald als commissionaire. Deze vertaling is onjuist, aangezien een Franse civil law commissionair een andere vertegenwoordiger is dan een common law general commission agent. Sinds 1929 wordt deze laatste term consequent in het Nederlands vertaald als commissionair, een vertaling die niet juist is.

Op grond van een rapport uit 1958 van de internationale kamers van koophandel is in art. 5, lid 6, van het OESO modelverdrag de voorwaarde opgenomen dat de onafhankelijke vertegenwoordigers moeten handelen in de normale uitoefening van hun bedrijf.

In het OESO modelverdrag uit 1963 werd in het commentaar voor het eerst verwezen naar een belangrijk element van de VV definitie, namelijk dat de vertegenwoordiger contracten moet afsluiten die de principaal binden.

In hoofdstuk 8 wordt de huidige interpretatie van het VV concept geanalyseerd. Primair is er sprake van een juridisch concept, namelijk het vertegenwoordigingsleerstuk. De voorwaarde dat een vertegenwoordiger de bevoegdheid moet hebben om overeenkomsten af te sluiten op naam van de principaal heeft alleen betekenis in civil law jurisdicties. Dat in het OESO commentaar wordt bepaald dat ook vertegenwoordigers die geen overeenkomsten letterlijk op naam van de principaal afsluiten, maar wel overeenkomsten afshuiten die de principaal binden, duidt op een juridische 
interpretatie. Zo moet het n.m.m. ook worden uitgelegd; er moet sprake zijn van een juridische binding, de vertegenwoordiger moet een aansprakelijkheid vestigen voor zijn principaal.

Er is nog steeds behoefte aan een uitzonderingsbepaling ex. art.5, lid 6, OESO modelverdrag. De makelaar kan n.m.m. uit dit artikel worden weggelaten aangezien de makelaar geen contracten afsluit, alleen partijen bij elkaar brengt. Een onathankelijke vertegenwoordiger vormt geen VV voor zijn principaal zelfs al zou hij bindende contracten op naam van de principaal afsluiten. Een onafhankelijke vertegenwoordiger is onafhankelijk, in zin van lid 6, als hij zowel juridisch als economisch onafhankelijk is en handelt in zijn normale bedrijfsuitoefening.

De praktische toepassingen van het VV concept worden besproken in hoofdstuk 9. Een belangrijke praktische toepassing is de commissionairstructuur. Het gaat hier om een distributiestructuur. Als een onderneming haar producten via een commissionair doorverkoopt, is er n.m.m. geen sprake van een VV indien deze commissionair voldoet aan alle vereisten van de onafhankelijke vertegenwoordiger, conform art.5, lid 6, OESO modelverdrag.

Een exclusieve commissionair, d.w.z. een commissionair die (vrijwel) exclusief voor è̀n principaal werkt, is geen general commission agent (cf. lid 6) en zal, indien hij bindende contracten afsluit voor zijn principaal, een VV voor zijn principaal kunnen vormen. Toetsing van de exclusieve commissionair aan art.5, lid 5, OESO modelverdrag is dan geboden.

Het VV concept speelt geen rol van betekenis inzake e-commerce. Vanwege het feit dat het VV concept gebaseerd is op een persoon van vlees en bloed, de vertegenwoordiger, die contracten voor zijn principaal afsluit, is dit concept niet berekend op handel via internet.

Als er sprake is van een VV is de vervolgvraag hoeveel winst aan de VV moet worden gealloceerd. Deze vraag staat centraal in hoofdstuk 10. Volgens de directe methode moet de vaste vertegenwoordiger worden behandeld alsof deze een onafhankelijke derde partij is. Een fictie die niet strookt met het feit dat de vaste vertegenwoordiger onderdeel uitmaakt van de onderneming van de principaal. Basis voor de winstallocatie van de VV is de commissie die deze ontvangt voor zijn werkzaamheden. Deze commissie zal een marktconforme commissie moeten zijn. Om deze te bepalen zall een vergelijking moeten worden gemaakt met een onafhankelijke vertegenwoordiger die vergelijkbare activiteiten verricht. $\mathrm{Na}$ aftrek van de directe verkoopkosten kan een deel van de winst aan de VV-staat worden gealloceerd. 
Ik concludeer (hoofdstuk 11) dat de term vertegenwoordiger uit het VV artikel een juridisch begrip is en als zodanig geïnterpreteerd dient te worden. Vanwege het feit dat het begrip vertegenwoordiger in belastingverdragen niet nader wordt gedefinieerd, zal nationale wetgeving de definitieve invulling c.q. definitie moeten bepalen. Het maakt daarom verschil uit of er sprake is van een common law of civil law jurisdictie.

Een onafhankelijke vertegenwoordiger is onafhankelijk als hij zowel juridisch als economisch onafhankelijk is en handelt in zijn normale bedrijfsuitoefening. Als de onafhankelijke vertegenwoordiger contracten afsluit die zijn principaal binden zal hij op grond van dit feit geen VV vormen indien hij verder aan de vereisten van de onafhankelijke vertegenwoordiger (cf. art. 5, lid 6, OESO modelverdrag) voldoet.

Bij beoordeling van de vraag of de vertegenwoordiger die alleen contracten onderhandelt en niet feitelijk afsluit een VV kan vormen, is n.m.m. doorslaggevend of de vertegenwoordiger zijn principaal bindt. Dit zal een juridische analyse inhouden gebaseerd op de civiele wetgeving (privat or contract law) van de verdragsluitende staten. 


\section{Nawoord}

$\mathrm{Nu}$ het werk af is, is het tijd om een aantal mensen te bedanken. Alhoewel fiscaal-juridisch onderzoek primair een solistisch gebeuren is, hebben veel mensen mij op diverse manieren geholpen bij dit onderzoek.

Allereerst wil ik mijn promotor prof.dr. Ton Daniels bedanken. Ton: ik kan gerust stellen dat zonder jouw voortdurende interesse en aanmoediging ik dit onderzoek nooit met succes had kunnen afronden. Jij hebt erg veel tijd en energie in mij gestoken. Je hebt mij geleerd om in de diepte te gaan en echt wetenschappelijk onderzoek te verrichten. We hebben veel gediscussieerd en we waren het vaak niet eens, maar dit zorgde er wel voor dat het onderzoek boeiend bleef en voortdurend in ontwikkeling. Je Socratische aanpak werkte uitstekend en zal mij als voorbeeld blijven dienen.

De leden van de beoordelingscommissie: voorzitter prof.dr. H.J. de Kluiver, prof.dr. W. Buijink, prof.dr. C. van Raad en prof.dr. L. Hinnekens will ik hartelijk danken voor de tijd en energie die zij hebben geïnvesteerd in het beoordelen van het manuscript.

Mijn paranimfen Willem Brouwer en Paul Tulling.

Beste Willem: jij had altijd tijd om mijn gezeur aan te horen en mij ongevraagd allerlei adviezen te geven. Je oprechte belangstelling voor mij en mijn onderzoek heb ik altijd zeer gewaardeerd.

Paul: je hebt mij in de belastingadvieswereld geïntroduceerd en daardoor mij de gelegenheid gegeven om nieuwe en waardevolle ervaringen op te doen. Ook na je vertrek naar Polen is ons contact gelukkig niet verwaterd. Het feit dat jij even uit Polen komt overwippen om mij tijdens de plechtigheid bij te staan spreekt boekdelen.

Verder dank ik prof.dr. Paul R. McDaniel, die het mogelijk heeft gemaakt dat ik op de New York University onderzoek heb kunnen doen. Prof. David Williams (Queen Mary \& Westfield College, London), dr. Guido Förster (Universität zu Köln), dr. Hans Arts (Universiteit Maastricht), mr.drs. Hans Pijl (Arthur Andersen Amsterdam), mr.drs. Erik Kamphuis (Arthur Andersen Rotterdam) voor de bereidheid om met mij inhoudelijk over mijn onderzoek te discussiëren. 
Arthur Andersen dank ik voor alle medewerking en financiële ondersteuning bij dit onderzoek. Speciale dank gaat uit naar Tjeerd Hoekstra, Rien van Dieren, Peter Willeme en Gertjan Hesselberth (Amsterdam), Jack Favre en Charles Manuel (Eindhoven).

Dank aan de capaciteitsgroep Belastingrecht (UM).

Paul Preece heeft zijn rol als "English-coach" en editor voortreffelijk op zich genomen.

Marie-Louise van Thoor (UM) dank ik voor het camera-ready maken van het manuscript. Tevens bedank ik Argie Lankkamp (UM), Han Kruitwagen \& Wendy Kremer (Arthur Andersen), Martine Peters (Clifford Chance) en Stef Sallaerts, ieder voor hun eigen bijdrage.

De meeste dank gaat echter uit naar mijn familie. Mijn schoonvader, Hans Koops sr., die ervoor gezorgd heeft dat ik in het belastingwereldje terecht ben gekomen.

Anne-Marie: het zit er eindelijk op. Dankzij jou stabiliteit en liefde heb ik dit project met succes kunnen afronden. Je zette me iedere keer weer met mijn beide benen op de grond als ik weer eens te hard van stapel liep. Je weet dat ik zonder jou dit boek nooit had kunnen schrijven, dus is dit boek ook van en voor jou.

Ten slotte dank ik mijn twee kinderen Sander en Suzanne voor het feit dat zij het hebben kunnen opbrengen om hun papa een paar jaar te delen met een boek en mijn computer te ontzien. 


\section{Appendix}

The following appendix includes quotes, in other languages than English, used in this thesis. My English translations of the quotes are within the text.

\section{CHAPTER 2}

Quote 1:

"Eine Willenserklärung, die jemand innerhalb der ihm zustehenden Vertretungsmacht im Namen des Vertretenen abgibt, wirkt unmittelbar für und gegen den Vertretenen."

Quote 2:

"Kommissionär ist, wer es gewerbsmäßig übernimmt, Waren oder Wertpapiere für Rechnung eines anderen (des Kommittenten) in eigenem Namen zu kaufen oder zu verkaufen."

\section{CHAPTER 3}

Quote 3:

"Als Betriebsstätten gelten Zweigniederlassungen, Fabricationsstätten, Niederlagen, Comptoire, Ein- oder Verkaufsstellen und sonstige Geschäftseinrichtungen zur Ausübung des stehenden Gewerbes durch den Unternehmer selbst, Geschäftsteilhaber, Procuristen oder andere ständige Verteter."

Quote 4:

"Die Befugnisse zum Gewerbebetricbe kômmen durch Stellvertreter ausgeübt werden; diese müssen jedoch nicht nur den für den selbstständigen Gewerbebetrieb im algemeinen, sondern auch den für das in Rede stehende Gewerbe insbesondere vorgeschriebenen Erfordernissen genügen." Quote 5:

“...beim ständigen Vertreter, trotz des Fehlens einer festen Anlage, die Wirtschaftlichen Verhältnisse im wesentlichen die gleichen seien wie bei der Betriebsstätte, das heißt wesentliche Unternehmensfunktionen wie der Vertragsabschluß werden im Inland ausgeführt."

Quote 6:

"Einkünfte aus Gewerbebetrieb, für den im Inland eine Betriebsstätte unterhalten wird oder ein ständiger Vertreter bestellt ist." 


\section{Quote 7:}

"...die als sein ständiger Vertreter, als sein Organ tätig ist, das heißt, in einem Abhängigkeitsverhâltnis zu ihm steht und an Stelle des Untemehmers, die in dessen Betrieb fallenden Handlungen vornimmt."

Quote 8:

"Diese Abhängigkeit ist aber nicht die soziale Abhängigkeit, die sich aus einem Angestelltenverhältnis ergibt, sondern die Bindung an die geschäftlichen Weisungen des vertretenen Geschaftsherrn. Sie kann aber auch ohne Vorliegen eines Angestelltenverhältnisses auf anderer Rechtsgrundlage vorhanden sein."

Quote 9:

"Als ein solches Organ (referring to the ständige Vertreter, APl.) kann aber auch ein selbständiger Gewerbetreibender, zum Beispiel ein Agent oder Spediteur, wirksam werden, soweit die von ihm ausgeübte Tätigkeit über den Rahmen seines eigenen Gewerbebetriebes hinausgeht."

Quote 10:

"Die deutsche Firma ist nicht verpflichtet, nicht einmal berechtigt, ohme vorherige Verständigung Einkäufe für gemeinsame Rechnung vorzunehmen. Infolgedessen handelt sie beim Einkauf zwar als Vertreter, aber nicht als ständiger Vertreter der holländischen Firma."

Quote 11:

"Was existiert, sind lediglich vertragliche Beziehungen zwischen den beiden Firmen, die dazu führen, daß Anspritiche der einen gegen die andere entstehen."

Quote 12:

"Insbesondere müsse eine Geschäftsverbindung von längerer Dauer und Stetigkeit vorliegen, bei der die Geschäfte auf Grund eines laufenden Vertragsverhältnisses, nicht dagegen auf Grund besonderer Abmachungen für das einzelne Geschäft abgeschlossen werden."

Quote 13:

"Diese Ähnlichkeit mit einer Betriebsstätte ist aber num dann gegeben, wenn die ausländische Firma durch eine dauernde Einrichthing für ihre Vertretung gesorgt hat. Es ist nicht erforderlich, daß der ständige Vertreter immer die gleiche Person ist, auch nicht, daB er seinen Wohnsitz im Inland that."

Quote 14:

"...wohl aber muB eine dauernde Einrichtung gegeben sein, die wirtschaftlich betrachtet ähnliche Zwecke verfolgt wie eine Betriebsstätte."

Quote 15:

ik...lst der ständige Vertreter ein Kommissionär oder Makler, der Geschaftsbeziehungen für das ausländische Unternehmen im Rahmen seiner ordentlichen Geschäftstätigkeiten unterhält, und ist die Besteuenung des ausländischen Unternehmens nicht durch ein Doppelbesteuerungsabkommen geregelt, so sind die Einkünfte des ausländischen Unternehmens insoweit nicht der Besteuerung zu unterwerfen. Das gilt auch, wenn der ständige Vertreter ein Handelsvertreter ( $\$ 84 \mathrm{HGB}$ ) ist, der weder eine allgemeine Vollmacht zu Vertragshandlungen und Vertragsabschlüssen für das ausländischen Unternehmen 
besitzt noch über ein Warenlager dieses Untemehmens vertugt, von den er regelmäßig Bestellungen fuir das Unternehmen ausfihrt."

Quote 16:

"Handelsvertreter ist, wer als selbständiger Gewerbetreibender ständig damit betraut ist, für einen anderen Unternehmer Geschäfte zu vermitteln oder in dessen Namen abzuschließen. Selbständig ist, wer im wesentlichen frei seine Tätigkeit gestalten und seine Arbeitszeit bestimmen kann."

\section{CHAPTER VI}

\section{Quote 17:}

"van andere in het buitenland gevestigden, die hier te lande persoonlijk of door gemachtigden een bedrijf, beroep, ambt, waardigheid, bediening of betrekking geregeld uitoefenen, of minstens drie maanden achtereen uitgeofend hebben, of van wie op grond van overeenkomsten of andere gegevens is aan te nemen dat zij dit gedurende minstens drie maanden achtereen zullen doen;"

Quote 18:

"...er van het uitoefenen van een bedrijf hier te lande door een vertegenwoordiger eerst sprake kan zijn, wanneer een hier te lande gevestigd natuurlijk of rechtspersoon in maam van en ten behoeve en voor rekening en in meer of mindere mate volgens de aanwijzingen van de in het buitenland gevestigde instelling handellingen verricht, welke tot het bedrijfsdoel van deze behoren;"

Quote 19:

"niet als vaste vertegenwoordiger beschouwd:

1. een volkomen onafhankelijke vertegenwoordiger;

2. een vertegenwoordiger die niet tot het afsluiten van transacties bevoegd is, ongeacht of hij voor spoedafleveringen een voorraad houdt;";

Art. 2(4)(c):

"een vaste inrichting of vaste vertegenwoordiger niet aanwezig geacht, ingeval slechts goederen in commissie worden gehouden."

Quote 20:

"Als vaste inrichtingen worden beschouwd de zetels der werkelijke leiding, filialen, fabrieken, werkplaatsen, agentschappen, magazijnen, kantoren, laboratoria, in- en verkoopkantoren, opslagplaatsen, alsmede alle andere vaste inrichtingen van productieven aard. Dat een onderneming, die in een der beide landen is gevestigd, met het andere land zakenrelaties onderhoudt, door tusschenkomst van een werkelijk zelfstandige vemnootschap (nakelaar, commissionnait, dochtermaatschappij, enz.) beteekent niet, dat die onderneming daar te lande een vaste inrichting heeft."

Quote 21:

"...Deze uitdrukking sluit niet in een vertegenwoordiging, tenzij de vertegenwoordiger een algemene machtiging heeft om te onderhandelen over overeenkomsten en deze af te sluiten namens de onderneming waarvan hij een 
vertegenwoordiger is, en dit recht gewoonlijk uitoefent, dan wel een goederenvoorraad heeft, waaruit hij regelmatig bestellingen uitwoert namens de onderneming."

\section{CHAPTER 7}

Quote 22:

"Le commissionnaire est celui qui agit en son propre nom ou sous un nom social pour le compte d'un commettant.

Les devoirs el les droits du commissionnaire qui agit au nom d'un commettant sont détermines par le Code Civil, livre III, titre XIII."

\section{CHAPTER 8}

Quote 23:

"Nach Überzeugung des Senats wollte das OECD-Musterabkommen...die Entstehung einer Vertreterbetriebsstätte jedoch von einem objektivierten, abstrakten Vergleichungsmassstab abhångig machen. Das können nur die ordentlichen Geschäftstätigkeiten eines der in Art. 5 Abs. 6 OECD-MustAbk. genannten Berufsgruppen sein." 


\section{Bibliography}

Abrams, H.E., \& Doernberg, R.L., 'Essentials of United States Taxation', (Khuwer Law International, The Hague/London/Boston, 1999).

Adams, S., 'Danger: Internet Taxes Ahead', Taxes, September 1997, pp. 495 - 509.

Albert, P.G.H., "Vaste Inrichting ", (FED BV Publishers, Deventer, 1994).

Alpert, H.H., \& van Raad, K. (Ed.), 'Essays on International Taxation', (Kluwer Law and Taxation Publishers, Deventer/Boston, 1993).

American Law Institute, Restatement of Agency, Restatement of the Law, (2nd ed.), vol. 1, (American Law Institute, Washington, 1957).

Amico, J.C., 'Introduction to the U.S. Income Tax System', (Kluwer, Deventer/Boston, 1993).

Andersen, R.E., 'Permanent Establishments for partners under treaties found from (somewhat) analogues code provisions', The Journal of International Taxation, May/June 1992, pp. 62 - 64 .

Asser, C., 'Vertegenwoordiging en rechtspersoon', (6th ed.), (Tjeenk Willink, Zwolle, 1985).

Atiyah, P.S., 'An Introduction to the Low of Contract', (4th ed.), (Clarendon Press, Oxford, 1989).

Aufricht, H., 'Guide to League of Nations Publications', (Columbia University Press, New York, 1951).

Avery Jones, J.F., \& Ward, D.A., 'Agents as Permanent Establishments under the OECD Model Tax Convention", European Taxation, May 1993, pp. 154 - 181.

Baker, P., 'Double Taxation Conventions and International Tax Law', (2nd ed.), (Sweet and Maxwell, London, 1994).

Baldi, R., 'Distributorship, Franchising, Agency', (Kluwer, Deventer, 1987).

Baranowksi, K.H., "Steuerfolgen bei Einschaltung eines "Ständigen Vertreters" ", IWB, nr. 8, 23 April 1997, pp. 369-378.

Barkan, I., "Virtual Permanence: Consideration of the Virtual Office in International Income Tax Treaties with the United States', Taxes, November 1997, pp. 648 657.

Becker, H., "The determination of income of a permanent establishment or branch', Intertax, 1989/1, pp. 12-15.

Becker, H., 'The Future of Transfer Pricing', Intertax, November/December 1996, pp. $535-537$.

Bellstedt, C., 'Der ständige Vertreter im Aussensteuerrecht', Der Betrieb 1968, nr. 38, pp. $1554-1557$.

Bischel, J.E., 'Income Tax Treaties', (Practising Law Institute, New York, 1978).

Bischel, J.E., \& Feinschreiber, R., 'Fundamentals of International Taxation', (2nd ed.), (Practising Law Institute, New York, 1985).

Bittker, B.I., \& Lokken, L., 'Fundamentals of International Taxation", (2nd ed.), (Warren, Gorham \& Lamont, Boston/New York, 1991). 
Bramwell, R., Hardwick, M. James, A., \& Kingstone, M., "Taxation of Companies and Company Reconstructions:" (6th ed.), (Sweet \& Maxwell, London, 1994).

Brodersen, C., \& von Kolczynski, H., "The Commissionaire: A tax-focused evaluation from Germany", Interiax, vol. 25, issue 5, pp. $201-210$.

Brood, E.A., \& Boomsluiter, E,, "Vaste vertegenwoordiger of onathankelijke ondernemer?; Weekblad Fiscaal Recht 1994/6090, pp. $197-208$.

Bühler, O., Einzelsteuerwecht', (Verlag Franz Vahlen, Berlin, 1938).

Bühring, 'Das Betriebsstättenprinzip in den Deutschen Doppelbesteuerungsabkommen', Der Betriebs-Berater, vol.18, June 301954, pp. $558-560$.

Burgers, I.J.J," "The OECD Report "Attribution of Income to Permanent Establishments": A Commentary”, IBFD Bulletin. March 1995, pp. $137-145$.

Campos, G., "Transfer Pricing Survey of Major Trading Nations", IBFD Bulletin, May 1996 , pp. $212-222$.

Capelle, K.H., \& Canaris, C-W, 'Handelsrecht', (19th ed.), (Beck, München, 1980).

Carroll, M.B., "International Tax Law', 2 Intemational Lawyer 692, 1968 , pp. 692 721.

Conti, L.T.M., "Will a Corporate Agent Be Respected for Federal Tax Purposes?', The Monthly Digest of Tax Articles, September 1991, pp. 25-28.

Cooke, P.J., \& Oughton, D.W., "The Common Law of Obligarions", (2nd ed.), (Butterworths, London, 1993).

Dale, H.P., 'Effectively Connected Income', Tax Law Review, vol. 42, 1987, pp. 734 744.

Daniels, A.H.M., 'Issues in Intemational Parnership Taxation', (Kluwer, Deventer/Boston, 1991.).

Daniels, A.H.M., "Winstallocatie bij internationale samenwerkingsverbanden", in the volume "Internationale winstallocatie", (Gouda Quint, Amhem, 1996).

David, R., \& Brierly, J.E.C., "Major Legal Systems in the World Today", (2nd ed.), (Stevens \& Sons, London, 1978).

Davies, D., 'Booth: Residence, Domicile and UK Taxation', (2nd ed.), (Butterworths, London, 1995).

'Diamond \& Diamonds International Tax Treaty of all Nations', (Diamond \& Diamond, New York, 1975).

Doemberg, R.L., 'International Taxation', (West Publishing Co., St.Paul, Minn., 1989).

Doemberg, R.L., \& van Raad, K., "US Tax Treaties', (Kluwer, Law and Taxation Publishers, Deventer/Bostion, 1991).

Dötsch, E., Gottschein, S., Stegmüller, H., Zenthöfer, W., 'Körperschaftstever', (Schäffer Verlag, Stuttgart, 1991).

Duden, K., 'Recht der Handelsvertreter', (8th ed., München 1977).

Edwardes-Ker, M., (Ed.), 'The International Tax Treaties Service', Dublin (loose-leaf). Engle, H.S., 'International Developments', The Joumal of Corporate Taxation, vol.23, no. 1, Spring 1996, pp. $77-81$.

Feteris, M.W.C., Gimbrère, J.A., \& van Muijen, G.J., "Holdingstruchuren" (Kluwer, Deventer, 1991). 
Fink, E.H., 'Transfer Pricing - Lessons from Sundstrand', Intertax, 1991/6-7, pp. 311 316.

Fisher, L., 'Besteuerung wirtschaftlicher Aktivitäten von Ausländern in Deutschland', (Köln 1995).

Flick, H., 'German report on the development in different countries of the concept of a permanent establishment', Studies on International Fiscal Law, Cahiers de droit Fiscal International, Volume L II, Stockholm, 1967.

Freud, N.S., "Are the Phrases "Trade or Business" and "Permanent Establishment" Coterminus ?', Taxes Management International, August 1985, pp. 289-290.

Fridman, G.H.L., 'The Law of Agency', (Butterworths, London, 1983).

Garelik, D.M., 'What constitutes doing business within the United States by a nonresident alien individual or a foreign corporation", Tax Law Review, vol.18, 1963, pp. $423-470$.

Gebbers, H., 'Der Ständige Vertreter bei Grundstückvermietung oder-verpachtung', Die Steuerliche Betriebspriffung 4/89, pp. $78-85$.

Ghysbrecht, J., 'Saving Tax when selling in Europe', European Counsel, October 1996, pp. $29-34$.

Gibson, J.T.R., 'South African Mercantile and Company Law', (15th ed.), (Juta \& Company Ltd, Cape Town, 1983).

Glicklich, P.A., Goldberg, S.H., \& Levine, H.J., 'Internet Sales Pose International Tax Challenges', Journal of Taxation, June 1996, pp. 325 - 330.

Grimme, A., \& Meijer, S.Y.T.,'De commissionair is niet een vaste vertegenwoordiger!', Weekblad Fiscaal Recht, 1998/6286, pp. 496 - 500.

Grinten, W.C.L., van der, 'Lastgeving', Monografieën Nieuw BW, B81, (Kluwer, Deventer, 1993).

Groot de, H. \& Stein, P.A., 'Grondirekken wan het handelsrecht', (7th ed.), (W.E.J. Tjeenk Willink, Deventer, 1996).

Guest, A.G., 'Anson 's Law of Contract', (26th ed.), (Clarendon Press, Oxford, 1984).

Gustafson, H., Peroni, J., \& Crawford Pugh, R., Taxation of International Transactions', (West Publishing Co., St.Paul, Minn. 1992).

Hafkenscheid, R.P.F.M., \& Hosman, A.T.G.M., Transfer pricing in het Nederland belastingrecht', (2nd ed.), (FED, Deventer, 1998).

'Halsbury's Laws of England', (4th ed.), (Butterworths, London, 1990).

Hamaekers, H., 'The Arm's Length Principle and the Role of Comparables', IBFD Bulletin, December 1992, pp. 602 - 605.

Hamilton, A., 'Toward A More Cogent Policy On Electronic Commerce', Tax Notes International, May 26, 1997, pp. $1705-1708$.

Handler, J.G., 'Ballentine 'S Law Dictionary', (Delmar, Albany NY, 1994).

Hardy Ivamy, E.R., \& Latimer, P., 'Casebook on Commercial Law', (3rd ed.), (Butterworths, London, 1979).

Harris, M.A., 'Advising the Cyberbusiness: Applying Fundamental Tax Concepts to Internet Sales', Taxes, December 1996, pp. $709-721$.

Hey, F.E.F., 'German Court Rules Remote-Controlled Pipeline Constitutes a PE', Tax Notes International, February 24, 1997, pp. $651-653$. 
Hinnekens, P., 'Belasting wan niet-inwonews', (Biblio, Kalmthout, 1994).

Hinnekens, L., \& Doemberg R.L., 'Electronic Commerce and International Taxation", (Kluwer Law Intemational, The Hague, London, Boston, 1999).

Horner, F.M., \& Owens, J., "Tax and the Web: New Technology, Old Problems", IBFD Bulletin, November/December 1996, pp. 516-523.

Hosson., F.C. de ${ }^{\prime}$ De herstructurering van het Europese concern; doelstellingen en fiscale gevolgen (I)', TWVS 1996, nr. 96, pp. 40 - 44 .

Hoyle, S., "Connecting factors fon UK corporate tax", International Tax Review, April. 1996, pp. $42-45$.

Huston, J., \& Williams, L., 'Permanent Esiablishment a planning primer', (Kluwer, Deventer/Boston, 1993).

Isenbergh, J., "The "Trade or Business" of Foreign Taxpayers in the United States', Taxes, December 1983, pp. $972-985$.

Jacobs, O.H., Endres, D., Selent, A., Storck, A., Intemationale Unternehmensbestewerung;, (C.H. Beck'sche Verlagsbuchhandlung, München 1995).

Jones, R.C. "Allocation Accounting for the Taxable Income of Industrial Enterprises', Taxation of Foreign and National Enterprises (vol. V), (League of Nations, Geneva, 1933).

Kaneko, H., 'Legal Aspects of the Transfer Pricing System', IBFD Bulletin, October 1995 , pp. $490-492$.

Kaplan, R.L., "Federal Taxation of International Transactions-principle, planning and policy", American Casebook Series, (West Publishing Co, St.Paul, Minn. 1998).

Karmelk, P., 'Besluit Inkomstenbelasting 1941', De Belastingwetgeving Serie D.B., No.2, (J. Noorduijn \& Zn., Gorinchem, 1954).

Kluge, V., 'Das Deutsche Internationale Stewerrecht', (C.H. Beck'sche Verlagsbuchhandlung, München 1992).

Kluiver, H.J., de, 'Onderhandelen en privaatrecht', PhD dissertation, (Kluwer, Deventer, 1992).

Kluiver, H.J., de, "Vertegenwoordiging en "apparent authority": een nieuwe fase?", WPNR, 93/6116, pp. 925-928.

Kroppen, H.K., "Funktionsverainderung der Vertriebstochtergesellschaft zum Kommissionär", IWB, nr. 23, December 1997, pp. $999-1004$.

Kroppen, H.K., \& Huffmeier, $\mathrm{S}$., "The German Commissionaire as a Permanent Establisliment under the OECD Model Treaty", Intertox, 1996/4, pp. 133-136.

Kuiper, W.G., "(East-West) Joint Ventures: a special phenomenon in intenational rax law?" (PhD dissertation, Leiden, 1988).

Kumpf, W., "Betriebsstätte: Prinzip und Definition" "die beschräkte Steuerpflicht, ed. W. Haarmann, forum der Internationalen Besteuerung, Band 2, (Verlag Dr. Otto Schmidt, Köln 1993).

Kumpf, W, "Besteuerung inländischer Betriebsstätten von Steuerausländern”, (Verlag Dr. Otto Schmidt, Köln 1982).

Kunze, K., 'Der Begriff der Betriebsstätte und des ständigen Vertreters', (InauguralDissertation, Mannheim, Germany, 1963). 
Laleman, P., "De agentuur vamuit fiscale hoek bekeken', A.F.T., January 1997, pp. $18-$ 35.

Larking, B., "Taxation of Permanent Establishments - The United Kingdom", (IBFD, Amsterdam, 1996).

Lazarow, H.I., "The OECD Draft Infuence on United States Income Tax Treaties", publication no. 24, IBFD, Amsterdam, 1976, pp. 30 - 48 .

Lechner, E., "Die Gewimpooling im Ertragstewerrecht", (Peter Deubner Verlag, Kölm, 1985).

Lee, R.W., "The Elements of Roman Law", (Sweet \& Maxwell, London, 1956).

Levin, H.J., \& Littman, A.J., 'Contracting out, not Branching out: Manufacturing revisited', Tax Mamagement Imternational 1993, pp. $343-353$.

Lidgard, H.H., and others, 'A Swwey of Commercial Agency', (Kluwer, Deventer, 1984).

Liebman, B.N., "Disregarding the Corporate Nominee: Commissionare $v$. Bollinger", The Monthly Digest of Tax Articles, March 1990, pp. $50-55$.

Lowe, R., 'Commercial Law', (6th ed.), (Sweet \& Maxwell, London, 1983).

Madigan, $\mathbb{R} . \mathrm{E}$., 'Taxation of the Shipping Industry', (2nd ed.) (Cornell Maritime Press, Maryland, USA, 1982).

Madole, E., 'Agents as Permanent Establishments under U.S. Income Tax Treaties', Tax Management International Jownal, June 10, 1994, pp. $281-298$.

Madole, E., 'The Importance of Being Independent: The Taisei Case', Tox Management International Journal, August 11, 1995, pp. $371-379$.

Maisto, G., 'General report: Transfer Pricing in the absence of comparable market prices", Cahiers de Droit Fiscal International, volume LXXVIIa, (Kluwer, Deventer/Boston, 1992).

Markensis, B.S., \& Munday, R.J.C., 'An owtine of the Law of Agency', (Butterworths, London, 1992).

Marks, D., "Commissionaire Structures", The Tax Journal, 19 January $1995, \mathrm{pp}, 11$-13.

Martin, E.A., "A Dictionary of Law", (3rd ed.), (Oxford University Press, Oxford, 1994).

McDaniel, P.R., \& Ault, H.J., 'Imtroduction to United States International Taxalion; (3rd rev. Ed.), (Kluwer, Deventer/Boston, 1989).

McIntyre, M.J., "The International Income Tax Rules of the United States", (Michie Law Publishers, Charlottesville, 1992).

Mössner, J.M. and others, Steuerecht International Tätiger Unternehmen, (Verlag Dr. Otto Schmidt, Köln, 1992).

Mössner, J.M., 'Rechtsprechungs-Report Internationales Steuerrecht', (Herne, Berlin, 1991).

Mulder, S.J.A., 'Hoofdzaken waardepapieren en iussenpersonen', (2nd ed.), (Kluwer, Deventer, 1995).

Münch, B., "Der doppeldeutige Begriff des ständigen Vertreters im geltenden Deutschen Aussensteuerrecht", Aussenwirtschatfsdienst des Betriebs-Beraters, March 1964, Heft 3, pp. 78-79. 
Nitikman, J., "The meaning of "Permanent Establishment"in the 1981 U.S. Model Income Tax Treaty: Part 2", The International Tax Journal 1989, pp. 257 - 277.

Norfolk, E.C.D. 'Non-Resident: United Kingdom Trade', 1980 British Tax Review, pp. $70-92$.

O'Donnell, T. \& DiSangro, P.A., "United States Tax Policy on Electronic Commerce", Intertax, vol. 25, pp. $429-444$.

OECD, 'Model Tax Convention on Income and on Capital', (OECD, Paris, 1997).

Oliver, M.C., "The Private Company in Germany"; (2nd ed.), (Kluwer Law and Taxation Publishers, Deventer/Boston, 1986).

Parry, C. (Ed.), "Consolidated Treaty Series", vol. 187, (Oceana Publications Inc, Dobbs Ferry NY)

Peltzer, M., Doyle, J.J., \& Allen, M.T., 'German Commercial Code', 2nd. rev. ed., (O. Schmidt, Köln, 1993).

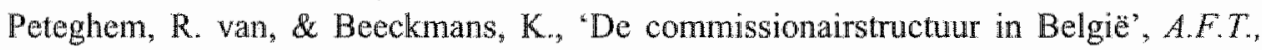
November 1996, pp. $379-402$.

Phillips, J.S., 'Tax Treaty Networks', (Worldwide Information Inc., Chur, 1988).

Pijl, H. \& Willeme, P., 'Permanent Agent--with particular reference to Dutch case law', IBFD Bulletin, January 1998 , pp. $12-18$.

Pitlo, A., 'De benoemde overeenkomsten', (8th ed.), (Gouda Quint, Arnbem, 1979).

Pleijsier, A., "The Agency Permanent Establishment under revision? Acting in the name of", or "what's in a name"?" Intertax, vol. 257, issue 6-7, pp. $247-254$.

Pleijsier, A., "De vaste vertegenwoordiger in beweging en de commissionaire op de tocht!', Weekblad Fiscaal Rech 1998/6274, pp. 5-19.

Pleijsier, A., 'De commissionair met èn principaal loopt risico!', Weekblad Fiscaal Recht 1998/6286, pp. 500-503.

Plejjsier, A., 'De commissionair structuur', Internationaal Belasting Bulletin, April 1998, pp. $1-6$.

Pottschmidt, G., \& Rohr, U., "Privatrecht fuir den Kawmanm", (8th ed.), (Verlag Franz Vohlen, München. 1990).

Raad, C., van, "De vaste vertegenwoordiging en de bepaling van de daarmee behaalde winst", Gielebundel, (Kluwer, Deventer, 1990).

Radad, C., van, (Ed.), 'Teksten Internationaal \& EG belastingrecht 1999-2000', (12th ed.) (Kluwer, Deventer, 1999).

Raad, K., van, (Ed.), "Model hroome Tax Treaties", (2nd ed.), (Kluwer Law and Taxation Publishers, Deventer/Boston, 1990).

Reynolds, F.M.B., 'Bowstead on Agency', (15th ed.), (Sweet \& Maxwell, London, 1985).

Reuschlein, H.G., \& Gregory W.A., 'Handbook on the Law of Agency and Partnership', (2nd ed.), (West Publishing Co., St. Paul, Minn., 1990).

Reynolds, B.W., \& Clinton Stretch, C., "First Tax Court Test of new IRS approach to Agency Permanent Establishment: Service losses'. Joumal of Taxation, September 1995 , pp. $169-173$. 
Rinkes, J.G.J., "Voorrangsregels en contractenrecht, een rechtsvergelijking', in 'Contracteren in de international praktik-Deel III', Wessels, B., Van Wechem, T.H.M. (Eds.), (Kluwer, Deventer, 1997).

Roberts, S.I. "The Agency Element of Permanent Establishment: The OECD Commentaries from the Civil Law View (part one \& two)", Intertax 1993/9 \& 10, pp. $396-420$ (part one), pp. $488-508$ (part two).

Rosenbloom, H.D., Sutherland, D.K., \& Ring, D.M., 'Taxation of Permanent Establishments - The United States; (IBFD, Amsterdam, 1994).

Rouwers, R.W.G., 'Buitenlandse belastingplicht', PhD dissertation (Vermande, Lelystad, 1996).

Roxan, I., 'Judicial Overrides of Double Taxation Conventions: The Case of a Permanent establishment', Imtertax, vol. 25, issue 11, pp. 367-378.

Samuels, L.B., \& Brown, P.A., 'Observations on the Taxation of Global Securities Trading', Tox Law Review, vol. 45, 1990, pp. $544-578$.

Sarafopoulos, J., 'Foreign Corporations/U.S. Income Taxation', Tax Management Foreign Income Portfolios, 1988 Tax Man. Inc, pp. 46 - 63.

Schaumburg, H., "Intemationales Stenerrecht", (Verlag Dr. Otto Schmidt, Köln 1993).

Schindler, G., 'IRS White Paper revisits Section 482', Intertax, 1989/2-3, pp. 56 - 61.

Schippers, H.H., "Eenige opmerkingen betreffende de begrippen "Etablissement

Stable"en "Agent Autonome"in verband met de vermijding der dubbele belasting", (PhD Dissertation, Leiden, 1934).

'Schlegelberger Handelsgesetzbuch', (5th ed.), (Vahlen, München, 1977).

Schlesinger, R.B., "Comparative Law', (The Foundation Press, New York, 1980).

Schmidt, K., 'Handelsrecht', (4th ed.), (Heymanss, Köln, 1994).

Schmitthoff, C.M,. \& Sarre, D.A.G., 'Charlesworth's Mercantile Law', (14th ed.), (Stevens \& Sons, London, 1984).

Schuurman \& Jordens, 'Wet op de Inkomstenbelasting 1914', No. 53a, (Tjeenk Willink, Zwolle, 1915).

Schwarz, R.S., "Taisei: U.S. agent did not create Permanent Establishment", The Joumal of International Taration, July 1995, pp. $292-300$.

Seitz, H., 'Carying-on the Direct Insurance Business in Germany through Foreign Insurance Companies", Intertax, 1996/6-7, pp. 230-241.

Setten, L.D. van, De commissionair in effecten", PhD dissertation, (Kluwer, Deventer, 1998).

Shaw, M.N., "International Law", (3rd ed.), (Grotius Publications, Cambridge, 1991).

Skaar, A., "Permanent Establishment, Erosion of a Tax Treaty Principle", Series on International Taxation (Kluwer, Deventer/Boston, 1991).

Slagter, W.J., 'Het afbreken van onderhandelingen', in Intemationale Commerciele Contracten, (Academic Service, Schoonhoven, 1993).

Smit, F.M., "de agentururovereenkomst tussen handelsagent en principaal, (W.E.J. Tjeenk Willink, Zwolle, 1990).

Sommerfeld, R.M., \& Anderson, H.M., and others, An Introduction to Taxation Advanced Topics", (2nd ed.), (Harcourt Brace Jovanovich, New York, 1982). 
"Statutes at Large, United Kingdom of Great Britain and Ireland" 5 \& 6 Victoriae, Public General Acts, 16 th vol., C.35.

Stevens, $\mathbf{S}$, "Intemet en belastingen", Weekblad Fiscaal Recht 1996/6222, pp. 1719 1731 .

Strikwerda, L., 'Inleiding tot het Nederlands Internationaal Privaatrecht', (14th ed.), (Wolters-Noordhof, Groningen, 1995).

Sunley, E., 'United States Section 482 White Paper', Intertax, 1989/2-3, pp. 45-56.

Swanick, M.F., \& Mudrick, M., \& Bouwman, E., 'Tax and Practical Issues in Commissionaire Structures", Tax Notes Intemational, January 13, 1997, pp. 137 143.

Tempel, A.J., wan den, "Relief from Double Taxation", Developments in taxation since World War I, no. VII., (IBFD, Amsterdam, 1967).

Thiele, C., 'Der Einkommensbegriff im US-amerikanischen Steuerrecht', RIW, 1997 , Heft 7, pp. $586-594$.

Tillinghast, D.R., "The Impact of the Internet on the Taxation of International Transactions", IBFD Bulletin, November/December 1996, pp. 524 - 526.

Toan, R.W., \& Gold, B.L. and others, 'Foreign broker was engaged in U.S. Trade or Business through the activities of an Agent: InverWorld versus Comr.", Tax Management International Joumal, October 1996, pp. 655-678.

Tsang Y.M.A., \& Belder N., "Electronic Commerce en het begrip vaste inrichting", $M B B$, ar. 10, October 1998, pp. 331-339.

Unlus, H.E., 'De agentumovereenkomst', (Kluwer, Deventer, 1990).

Verhagen, H.L.E., "Agency in Private Intemational Law", (dissertation, Nijmegen, 1995).

Vink, M., Substantive intemational corporate income tax issues" "Caught in the Web: the Tax and Legal Implications of Electronic Commerce, (FED, Deventer, 1998).

Vishny, P.H., 'Guide to International Comnerce Law', (Shepard's/McGraw-Hill, Colorado Springs, 1981 ).

Vogel, K., 'Double Taxation Conventions', (3rd ed.), (Kluwer Law and Taxation Publishers, London/The Hague/Boston, 1998).

Wainman, D., "The Agent of a Non-Resident", The Tax Joumal, 27 April 1995, pp. 8 II.

Weeghel, S. van, 'Artikel 7 (winst wit onderneming)', in the loose-leaf edition "Internationaal belastingrecht", (Delwel, Den Haag).

Williams, R.L., 'Permanent Establishments in the United States', Tax Lawyer, wol. 29, no. 2, pp. $277-354$.

Wurm, M., 'Prokura und. Handlungsvollmacht-Handelsvertreter und Makler', (Carl Heymanns Verlag KG, Köln, 1988). 


\section{League of Nations Publications}

LON, 'Report of Double Taxation', LON, Document E.F.S. 73/F.19, Geneva April 5, 1923.

LON, 'Double Taxation and Tax Evasion', Report and Resolutions, Document C.115.M.55.1925.II (F.212), Geneva February 7, 1925.

LON, Double Taxation and Tax Evasion Report presented by the committee of Technical Experts on Double Taxation and Tax Evasion', Document C.216.M.85.1927.II., Geneva, April 1927.

LON, 'Double Taxation and Fiscal Evasion', Collection of International Agreements and Internal Legal Provisions for the Prevention of Double Taxation and Fiscal Evasion, Document C.345.M.102.1928.II, Geneva, October 1, 1928.

LON, Fiscal Committee, 'Report to the Council on the Work of the First Session of the Committee', Document C.516.M.175.1929.II, Geneva, October 17-26, 1.929.

LON, "Taxation of Foreign and National Enterprises" League of Nations, Geneva, 1932.

R.C. Jones, "Allocation Accounting for the Taxable Income of Industrial Enterprises", Taxation of Foreign and National Enterprises, Volume V, League of Nations, Geneva, 1933.

M. B. Carroll, "Prevention of International Double Taxation and Fiscal Evasion, "Two Decades of Progress under the League of Nations", Official no.: F. Fiscal/111, Geneva, June 22, 1939.

LON, "Model Bilateral Conventions for the Prevention of International Double Taxation and Fiscal Evasion', Mexico, D. F., July 1943, Geneva 1945, Official No: C.2.M.2. 1945.I1.A.

LON, "London and Mexico Model Tax Conventions", Commentary and "Text, Official no: C.88.M.88.1946.II.A., Geneva, November 1946. 



\section{Curriculum Vitae}

Arthur Pleijsier was born on the 24th September 1961 in The Hague, The Netherlands. He holds a masters degree in tax law from the Catholic University Brabant. He worked from 1983-1992 for the Dutch Tax Administration.

Currently, he lectures in international tax law at the Maastricht University and works at Arthur Andersen as a tax manager, primarily active within the Arthur Andersen Academy, the Arthur Andersen Knowledge Institute. He is visiting professor of the University of Porto (Faculdade de Direito da Universidade do Porto).

He is married to Anne-Marie and has two children, Sander and Suzanne. 